\title{
UNIVERSIDADE DE SÃO PAULO \\ FACULDADE DE FILOSOFIA, LETRAS E CIÊNCIAS HUMANAS DA UNIVERSIDADE DE SÃO PAULO
}

(FFLCH-USP)

O Allianz Parque na economia do futebol,

do Estádio-Arquibancada ao Estádio-Shopping.

(exemplar corrigido)

São Paulo - SP

2020 


\section{JOSÉ LUIZ PORTELLA PEREIRA}

\section{O Allianz Parque na economia do futebol,}

\section{do Estádio-Arquibancada ao Estádio-Shopping.}

Exemplar corrigido da Tese de Doutorado em PDF apresentada ao Departamento de História da Faculdade de Filosofia, Letras e Ciências Humanas da Universidade de São Paulo, sob a orientação do Professor Doutor José Jobson de Andrade Arruda.

São Paulo - SP

2020 
Autorizo a reprodução e divulgação total ou parcial deste trabalho, por qualquer meio convencional ou eletrônico, para fins de estudo e pesquisa, desde que citada a fonte.

Catalogação na Publicação

Serviço de Biblioteca e Documentação

Faculdade de Filosofia, Letras e Ciências Humanas da Universidade de São Paulo

P426a Pereira, José Luiz Portella
o Alíanz Parque na economia do futebol, do
Estádio-Arquibancada ao Estádio-Shopping. / José
Luiz Portella Pereira ; orientador José Jobson de
Andrade Arruda. - São Paulo, 220.
235 f.
Tese (Doutorado)- Faculdade de Filosofia, Letras
e Ciências Humanas da Universidade de São Paulo.
Departamento de História. Área de concentração:
História Econômica.
1. História Econômica. 2. Economia do Futebol. I.
Arruda, José Jobson de Andrade, orient. II. Título.




\title{
ENTREGA DO EXEMPLAR CORRIGIDO DA DISSERTAÇÃO/TESE
}

\section{Termo de Ciência e Concordância do (a) orientador (a)}

\author{
Nome do (a) aluno (a): José Luiz Portella Pereira \\ Data da defesa: $13 / 04 / 2020$ \\ Nome do Prof. (a) orientador (a): Prof. Dr. José Jobson de Andrade Arruda
}

Nos termos da legislação vigente, declaro ESTAR CIENTE do conteúdo deste EXEMPLAR CORRIGIDO elaborado em atenção às sugestões dos membros da comissão Julgadora na sessão de defesa do trabalho, manifestando-me plenamente favorável ao seu encaminhamento e publicação no Portal Digital de Teses da USP.

São Paulo, 05/06/2020.

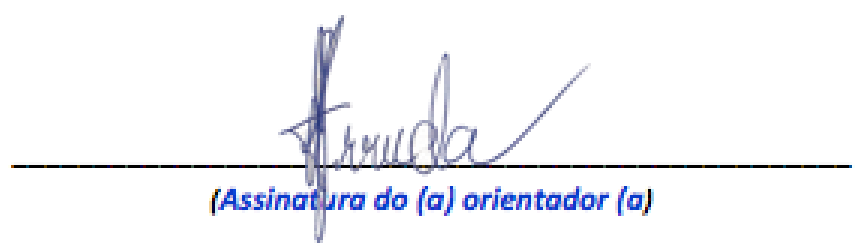




\section{FOLHA DE APROVAÇÃO}

Nome: José Luiz Portella Pereira

Titulo: O Allianz Parque na economia do futebol, do Estádio-Arquibancada ao Estádio-Shopping

Tese de doutorado apresentada ao departamento de História da Faculdade de Filosofia, Letras e Ciências Humanas da Universidade de São Paulo, sob a orientação do Professor Doutor José Jobson de Andrade Arruda.

Aprovado em:

Banca Examinadora

Orientador: Prof. Dr.

Instituição: Assinatura: 


\section{DEDICATÓRIA}

À minha mãe, Dirma Portella Pereira;

Angélica, mulher inigualável; Lucas e Luana, filhos amados;

À minha querida irmã Leila;

Ao meu pai, Ary Tupinambá Pereira ( in memoriam). 


\section{AGRADECIMENTOS}

Realizar uma tese é conhecer a si mesmo. Embrenhar-se nos meandros dos próprios limites e dificuldades, lidar com algumas virtudes, deparar-se com uma solidão quase infinita e, por vezes, encontrar alegremente pessoas que permanecerão para sempre com a gente. Trata-se de desafio que coloca o autor em contato com as respectivas persona e sombra, e também o que emerge do inconsciente.

Não é tarefa para uma pessoa só. Sem um conjunto de orientadores, professores, colaboradores, amigos e questionadores, não se faz.

Nesse longo trabalho, o caminho, que parece comum, usual, por haver miríade de pesquisas acadêmicas, transforma-se em saga pessoal inolvidável para o autor,onde as conquistas e intempéries o ensina; e me ensinou tantas coisas que ignorava, situações e fatos que pareciam de amplo domínio, ressurgindo por outras veredas, adquirindo faces novas, em aprendizado dificilmente comparável.

Nessa saga pessoal, devo muito, a tantos. Para o mundo são poucos, para mim, nunca tão poucos para os outros, foram tantos e tão importantes.

Agradeço à professora Maria Arminda do Nascimento Arruda, para mim, luz maior desse trabalho, desde que me acolheu na primeira hora, quando era apenas alguém que sonhava com a pesquisa acadêmica. Inesquecível.

Agradeço ao meu orientador, professor José Jobson de Andrade Arruda, que me tratou com o devido e necessário rigor acadêmico, ensinando-me o significado fundamental para o trabalho da distância entre autor e obra, autor e pesquisa. Suas arguições críticas foram cruciais no desenvolvimento da tese.

Agradeço aos amigos essenciais Eduardo Ghirardelli Gonçalves, Simone Vicentini e Simone Queiroz, que estoicamente me ajudaram de forma incansável e decisiva. Sem eles, não lograria vencer o desafio. À Jaqueline e à Isabela, também relevantes.

Agradeço aos professores Hernani Maia Costa e Vera Lucia Amaral Ferlini que realizaram minhas qualificações com observações fundamentais. 
Cabe também recordar os professores que ministraram as disciplinas dos créditos regulamentares, sobretudo, os professores Paolo Ricci e Jorge Almeida. Agradeço também aos professores participantes da defesa de tese, professor Rui Gomes Braga Neto, professor Fernando Henrique Cardoso, professor Luiz Gonzaga de Mello Belluzzo. Ao professor Paulo Martins, que com paciência e prontidão me ensinou a enfrentar os obstáculos desse desafio.

Agradeço ao Programa de Pós-Graduação em História Econômica da Universidade de São Paulo, que me ofertou as condições para o desenvolvimento do trabalho, me propiciando a honra de estudar em instituição histórica, que iluminou e ilumina o caminho do saber no Brasil com o seu patrimônio inestimável.

Agradeço aos amigos da Sociedade Esportiva Palmeiras que me ajudaram na pesquisa.

Desejo agradecer também a cada amigo que me ajudou de algum modo, uma lista considerável, entre eles o amigo Juca Kfouri que me cedeu parte de sua notável biblioteca sobre futebol.

E à minha família, sempre presente ao meu lado em todos os momentos.

Escrever uma tese é conhecer a si mesmo, sobretudo na minha idade, é resgatar o significado do banco escolar, é entender o valor do trabalho coletivo, é dar uma pequena contribuição à sociedade, com o desejo de mudar o mundo. 
"Todas verdades são fáceis de serem entendidas a partir de quando elas são descobertas. O ponto é descobri-las".

(Galileu Galilei)

"A dificuldade real não reside nas novas ideias, mas em conseguir escapar das antigas".

(John Maynard Keynes)

"Nós não podemos resolver nossos problemas com o mesmo raciocínio que utilizamos quando os criamos".

(Albert Einstein) 


\section{RESUMO}

O tema base desse trabalho é a forma de gestão dos clubes de futebol ao longo das respectivas histórias no Brasil, observando as consequências do ato de governar sobre as matrizes econômicas que os suportaram.

A história econômica do futebol combinada com a ação da indústria cultural e o processo conhecido como "globalização" suscitaram uma nova economia, a Economia do Futebol. A evolução de tal processo, que se inicia no amadorismo dos participantes alcançando o "futebol como negócio", é o cenário de fundo do trabalho.

O objeto desta tese é o Allianz Parque, estádio da Sociedade Esportiva Palmeiras, em São Paulo, que emerge do movimento de transformação dos estádios no país, com vistas à Copa do Mundo de Futebol de 2014, a provocar, de modo não intencional, a possibilidade de mudança da matriz econômica dos clubes.

A transformação do estádio Palestra Italia em Allianz Parque exibe o trajeto da alteração da matriz econômica, onde a metamorfose se expressa por dois cursos; um tangível, a mutação do estádio-arquibancada para o estádio-shopping, e outro intangível, a mudança de vínculo do torcedor com o clube: de torcedorapaixonado a torcedor-cliente, esse novo ente que foi engendrado, sobretudo, pela globalização do futebol.

O trabalho propõe-se a superar os limites da constatação da matriz econômica produzida em nosso futebol, ao avaliar o modelo de governança necessário para assegurar a perenidade da nova matriz, que permite a independência econômica dos clubes no Brasil.

Palavras-chave: Estádio-arquibancada, estádio-shopping, matriz econômica, economia do futebol, torcedor-apaixonado, torcedor-cliente. 


\begin{abstract}
The main focus of this work is the way in which football clubs have been managed throughout their respective histories in Brazil. This study pays specific attention to the consequences of the models of governance based on the economic matrices that have supported them.

The economic history of football combined with the action of the cultural industry and the process known as "globalization" has spawned a new economy: the Football Economy. The process, which begins with the amateur management practices of the participants evolving into "football as business", is the background of the work.
\end{abstract}

The object of this thesis is Allianz Parque is the stadium belonging to Sociedade Esportiva Palmeiras, in São Paulo, Brazil. The new stadium emerges from the movement focused on transforming the sports infrastructure in Brazil , with a view to the 2014 Football World Cup and unintentionally provokes the possibility of changing the economic matrix of the clubs.

The transformation of Palestra Italia stadium into Allianz Parque shows the trajectory of change in the economic matrix, where the metamorphosis is expressed by two paths. The first changeis tangible; the conversion of the stadiumgrandstand to the shopping-stadium. The second is intangible; the change of the connection between the fan and the club: from passionate-supporter to consumersupporter, who became a new entity, engendered mainly by the globalization of football.

This paper aims to overcome the paradigm of the establishment of the economic matrix produced in our football by evaluating the governance model necessary to ensure the continuity of the new matrix, which allows the economic independence of clubs in Brazil.

Keywords: Stadium-grandstand, stadium-mall, economic matrix and soccer economy -torcedor-apaixonado, torcedor-cliente 


\section{LISTA DE ILUSTRAÇÕES}

Figura 01 Parque Antarctica em 1922

Figura 02 Imagem Panorâmica do estádio em 1936

40

Figura 03 O Projeto original

Figura 04 Palestra Italia

Figura 05 Demolição do Palestra Italia

Figura 06 O Milagre de Berna (Das Wunder von Bern)

Figura 07 Estádio Allianz Parque

Figura 08 Antes e depois: Estádio Parte Externa

Figura 09 Antes e depois: Estádio Parte Interna

Figura 10 Antes e depois: Gramado e arquibancada

Figura 11 Antes e depois: Cadeiras

Figura 12 Antes e depois: Campo

Figura 13 Atual: Campo Grama Sintética

Figura 14 Modelo de Financiamento da Arena Corinthians

Figura 15 Comparação do Maracanã com maiores em despesas 


\section{LISTA DE TABELAS}

Tabela 01 Dados do Estádio Palestra Italia

39

Tabela 02 Público e Renda - Campeonato Paulista: Palestra Italia 45 2007 em Mil R\$

Tabela 03 Público e Renda - Campeonato Paulista: Palestra Italia 2008 em Mil $R \$$

Tabela 04 Público e Renda - Campeonato Paulista: Palestra Italia 46 2009 em Mil R\$

Tabela 05 Público e Renda - Campeonato Paulista: Palestra Italia 2010 em Mil R\$

Tabela 06 Público e Renda - Campeonato Brasileiro: Palestra Italia 48 2007 em Mil R\$

Tabela 07 Público e Renda - Campeonato Brasileiro: Palestra Italia 2008 em Mil R\$

Tabela 08 Público e Renda - Campeonato Brasileiro: Palestra Italia 50 2009 em Mil R\$

Tabela 09 Público e Renda - Campeonato Brasileiro: Palestra Italia 2010 em Mil R\$

Tabela 10 Público e Renda - Campeonato Brasileiro: Allianz Parque 51 2016 em Mil R\$

Tabela 11 Público e Renda - Campeonato Brasileiro: Allianz Parque 2017 em Mil R\$

Tabela 12 Público e Renda - Campeonato Brasileiro: Allianz Parque 52 2018 em Mil R\$ 
Tabela 14 Seleção Brasileira da Copa 1994

Tabela 2020 Clubes mais valiosos da Europa em 2018

Tabela 24 Ranking - Sócio torcedor 2013 
Tabela 29 Ranking Sócio-torcedor 2018

Tabela 30 Ranking Sócio-torcedor 2019

Tabela 31 Torcedor: Datafolha 2008 (em percentual)

Tabela 32 Comparação dos estádios: Allianz Parque X Pacaembu

Tabela 33 Receitas Operacionais (em milhões $\mathrm{R} \$$ )

Tabela 34 Receitas operacionais de $2007-2008$

Tabela 35 Receitas operacionais de $2008-2009$

Tabela 36 Receitas operacionais de $2009-2010$

Tabela 37 Receitas operacionais de 2010-2011

Tabela 38 Receitas operacionais de 2011-2012

Tabela 39 Receitas operacionais de $2012-2013$

Tabela 40 Receitas operacionais de 2013-2014

Tabela 41 Receitas operacionais de $2014-2015$

Tabela 42 Receitas operacionais de 2015 - 2016

Tabela 43 Receitas Operacionais $2016-2017$ 
Tabela 45 Público e renda recorde de 1987, 1988, 1999 (em milhões $\mathrm{Cz} \$$ )

Tabela 46 Mapa Estratégico do Banco Volkswagen

Tabela 47 Mapa Estratégico do Futebol

Tabela 48 Comparação dos estádios

Tabela 49 Receita Total / Clubes (em R $\$$ mil)

Tabela 51 Renda Líquida dos 20 Clubes da Série A Campeonato 222 Brasileiro 2018 


\section{LISTA DE GRÁFICOS}

Gráfico 01 Distribuição das receitas - Palestra Italia 2007

Gráfico 02 Distribuição das receitas - Palestra Italia 2008

Gráfico 03 Distribuição das receitas - Palestra Italia 2009

Gráfico 04 Distribuição das receitas - Palestra Italia 2010

Gráfico 05 Valores pagos em 2017 pela Globo

Gráfico 06100 anos de crescimento do PIB no Brasil (\%)

108

Gráfico 07 Evolução da Receita Operacional ao longo dos anos (em milhões $R \$$ )

Gráfico 08 Patrimônio Líquido: Positivo (em milhões R\$)

Gráfico 09 Receitas por Tipo - SEP - Período Allianz Parque 2017

Gráfico 10 Receita por Tipo - SEP - Período Allianz Parque 2018

Gráfico 11 Comparativo anual: Receitas da arena (em Milhões R\$)

Gráfico 12 Patrocínio e Publicidade

Gráfico 13 Cotas de TV 2016-2015 (milhões R\$)

Gráfico 14 Patrocínio e Publicidade 2016 - 2015 (milhões R\$) 
Gráfico 16 Clube Social e Esporte Amador 2016 - 2015 (milhões R\$)

Gráfico 17 Bilheteria $2016-2015$ (milhões $\mathrm{R} \$$ ) 


\section{LISTA DE SIGLAS}

$\begin{array}{ll}\text { VAR } & \text { Video Assistant Referee } \\ \text { MSI } & \text { Micro-Star International } \\ \text { BSC } & \text { Balanced Scorecard } \\ \text { CIDs } & \text { Certificados de Incentivo ao Desenvolvimento } \\ \text { TJLP } & \text { Taxa de Juros de Longo Prazo } \\ \text { CSN } & \text { Companhia Siderúrgica Nacional } \\ \text { FAM } & \text { Faculdade das Américas } \\ \text { FAN Cup } & \text { Copa d'A Associação de Futebol } \\ \text { AAA } & \text { Amsterdam Arena Advisory } \\ & \text { Copa Libertadores da América }\end{array}$


Sumário

INTRODUÇÃO: PROPOSIÇÕES TEMÁTICAS E METODOLÓGICAS ........... 19

CAPÍTULO I - A HISTÓRIA E OS ESTÁDIOS................................................ 33

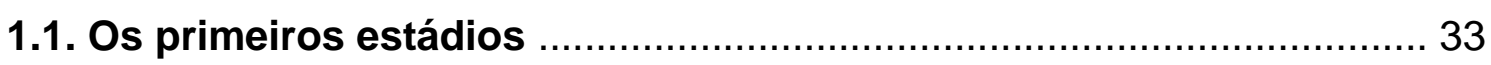

1.2. Do Parque Antarctica ao Allianz Parque …….................................. 36

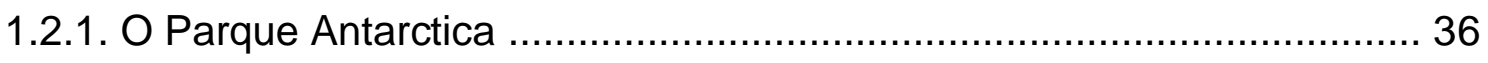

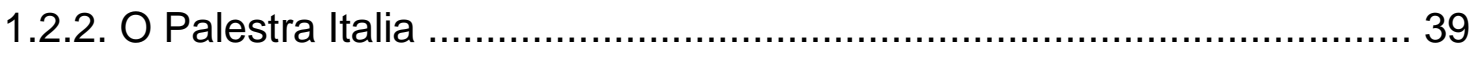

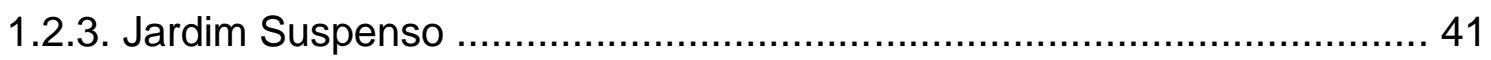

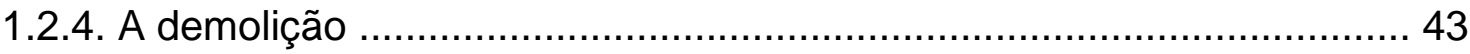

1.3. Sociedade Esportiva Palmeiras........................................................ 45

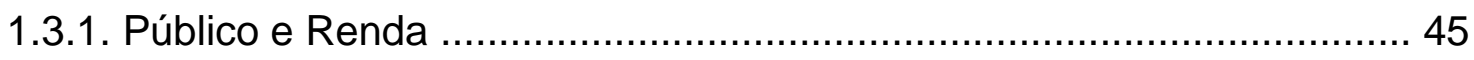

(a) Campeonato Paulista - Palestra Italia ………….................................. 45

(b) Campeonato Brasileiro - Palestra Italia .................................................. 48

1.3.2. Distribuição das Receitas .............................................................. 53

CAPÍTULO II - A ECONOMIA DO FUTEBOL........................................... 59

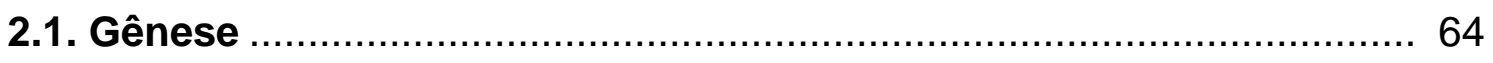

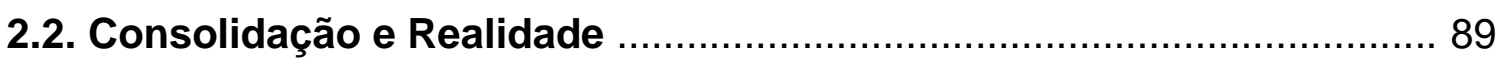

2.3. A Economia do Futebol nos dias atuais ………................................ 95

CAPÍTULO III - A HISTÓRIA E O ESTÁDIO COMO ATIVO ECONÔMICO.... 98

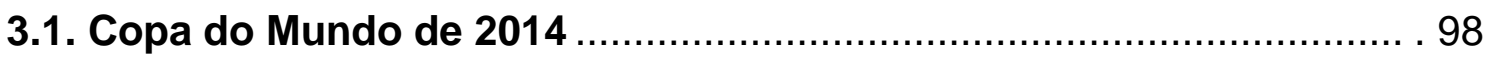

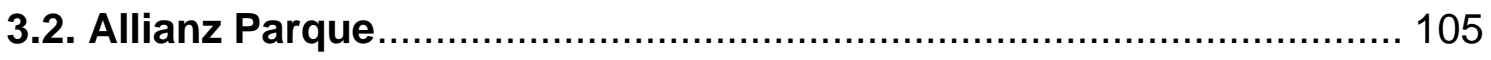

3.2.1. A Conversão do Palestra Italia no Estádio-Shopping .............................105

3.2.2. O Allianz Parque na Economia do Futebol ........................................ 132

3.3. Demonstrativo das Receitas....................................................... 133

3.4. A mudança econômica e a matriz financeira ......................................140

3.4.1. Governança e a Matriz Econômica ...................................................140 
4.1. Resultado Econômico - Financeiro …………………………........ 144

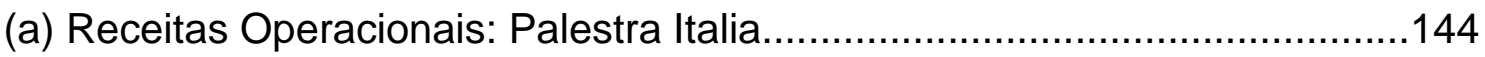

(b) Receitas Operacionais: Allianz Parque...................................................152

CAPÍTULO V - ALÉM DA NOVA MATRIZ ECONÔMICA .............................. 162

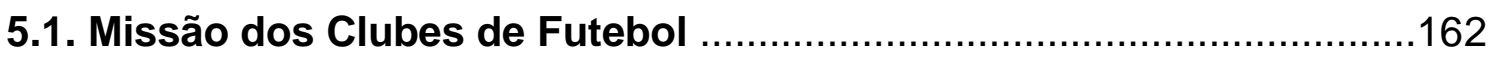

5.2. O Antagonismo Formal e os modelos de Governança ......................164

5.3. $O$ fator humano na gestão do futebol ................................................. 174

5.3.1. A vaidade no manejar da matriz econômica........................................ 185

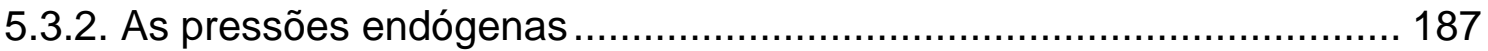

5.3.3. Subordinação, Insubordinação ao Arcabouço Vigente .......................... 189

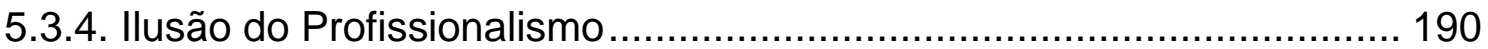

5.4. Parâmetros para a medição da eficiência e eficácia do modelo ....... 192

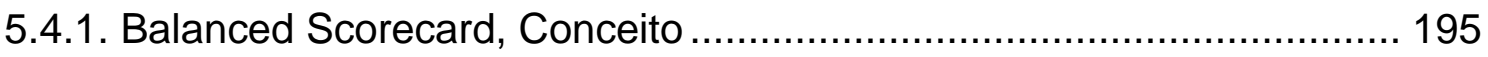

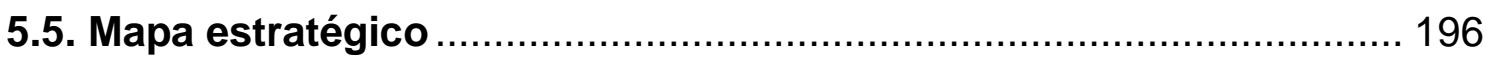

CAPÍTULO VI - COMPARAÇÃO COM OUTROS MODELOS...................... 200

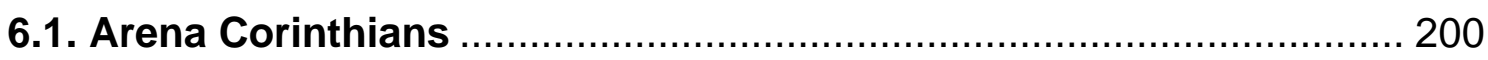

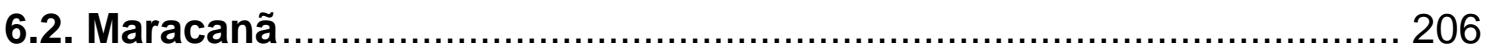

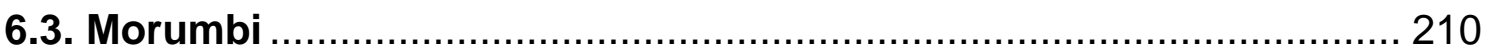

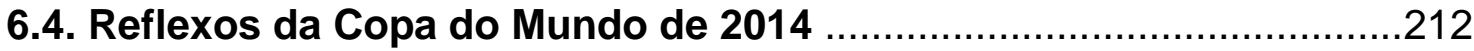

6.4.1. Evolução das receitas dos clubes brasileiros ..................................... 214

6.4.2. Ranking das Receitas: 22 Clubes Brasileiros .................................... 220

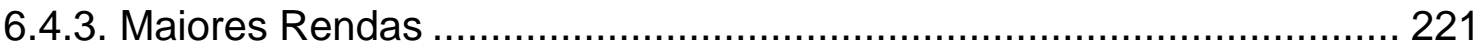

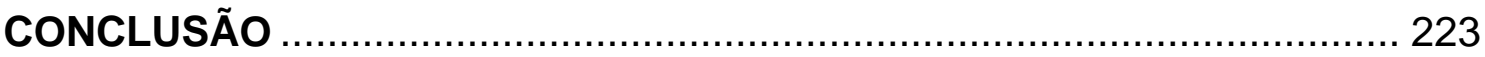

BIBLIOGRAFIA 


\section{INTRODUÇÃO: PROPOSIÇÕES TEMÁTICAS E METODOLÓGICAS}

O futebol brasileiro tem dois momentos históricos, antagônicos, para a respectiva filosofia do conhecimento: 1950 e 1958. No primeiro, a frustração absoluta com a perda de uma Copa do Mundo em seu território, no estádio mais simbólico, o Maracanã, quando precisava de um empate, assinalou o primeiro gol do jogo aos 2 minutos do segundo tempo e assistiu o adversário "virar" o placar. Toda a vontade de potência que se construía transformou-se em sensação de humilhação, fazendo emergir no brasileiro o espectro do complexo de vira-latas.

Em 1958, com uma Seleção que deixou o país desacreditada, em que pese a imensa qualidade de seus componentes, o Brasil alcançou o topo, sagrando-se campeão mundial de futebol na Suécia, primeira vez que um país da América vencia em território europeu. O país atravessava um período de extremo otimismo induzido pelo governo Juscelino Kubitschek, com seu plano "50 anos em 5" e um estilo jovial, alegre e conciliador. Foram acontecimentos que se transformaram em efemérides para a técnica e a visibilidade do futebol brasileiro no mundo, mas que não catalisaram nenhum processo de mudança na gestão dos clubes e na governança das entidades organizadoras, tanto na Confederação Brasileira de Desportos - CBD, quanto nas federações estaduais, embora o planejamento comandado por Paulo Machado de Carvalho, chefe da delegação de 1958, tenha sido inovador e exemplar. A conquista inédita e grandiosa não logrou impelir os dirigentes brasileiros a executarem algo na mesma linha nos respectivos clubes.

Só após 57 anos do desastre no Maracanã e 49 anos depois da glória no Estádio Räsunda, na segunda Copa que se realizou no país, emergiu o dispositivo catalisador para uma substancial mudança na matriz econômica dos clubes, que se inicia em 2007, quando a FIFA anuncia o Brasil como sede da Copa de 2014, consequentemente implicando a exigência de estádios com padrão-FIFA, modelo obrigatório para tal tipo de competição. 
Desde a introdução oficial do futebol no Brasil, por Charles William Miller ${ }^{1}$, em 14 de abril de 1895, numa "fria tarde de outono", como ele mesmo registrou, na Várzea do Carmo, onde hoje se encontram as ruas do Gasômetro e Santa Rosa em São Paulo², persiste a questão: os clubes brasileiros têm requisitos econômicos para se manter de forma autônoma, sustentável e atingirem a realização das respectivas potencialidades?

No fundo, o que se deseja saber é se os clubes brasileiros têm condições de sustentação própria de modo a ganharem escala nacional e internacional. Existiria um arcabouço econômico e financeiro? Os clubes grandes terão uma matriz econômica que os coloque entre os maiores clubes do mundo em prestígio e receita líquida?

$\mathrm{Na}$ verdade, o que sempre intrigou os que procuraram estudar a questão estrutural do futebol brasileiro foi se o ceticismo existente quanto à capacidade de os clubes alcançarem matriz econômica sistêmica e duradoura fazia sentido ou era fruto de descrença exacerbada provocada pelo que Nelson Rodrigues ${ }^{3}$ chamou de "complexo de vira-latas"4 do brasileiro, de modo que a sensação de inferioridade nos impedisse de transpor a barreira da desorganização administrativa.

Haveria fundamentos econômicos, competência técnica e capacidade gerencial para que os clubes brasileiros conquistassem estágio de emancipação e autonomia? O desafio seria puramente metodológico, processual, sistêmico ou necessitar-se-ia vencer questão mais profunda, anímica, ligada ao caráter e à personalidade do brasileiro? Tratava-se de vencer uma descrença em nossa

${ }^{1}$ Charles William Miller foi um esportista brasileiro, considerado o "pai" do futebol e do rugby no Brasil.

2 SALUM, 2015, Apud MILLS, 1996, p.37: "O ano de 1894 está ligado à "história oficializante" do futebol, quando Charles Miller, filho de imigrantes britânicos, nascido na Rua Monsenhor de Andrade, na região do Brás, retornou de seus estudos no Banister Court School, na cidade portuária de Southampton, onde participou da seleção do condado de Hampshire, jogando na posição de center-forward. Em depoimento para a Revista $\mathrm{O}$ Cruzeiro, em 1952, ele relatou os primeiros passos: 'Numa tarde fria de 1895, reuni os amigos e convidei-os a disputarem uma partida de football. Aquele nome, por si só, era novidade, já que naquela época somente conheciam o críquete'."

${ }^{3}$ Nelson Falcão Rodrigues foi um teatrólogo, jornalista, romancista, folhetinista e cronista de costumes e de futebol brasileiro, e tido como o mais influente dramaturgo do Brasil.

${ }^{4}$ RODRIGUES, Nelson. À sombra das chuteiras imortais. São Paulo: Cia. das Letras, 1993. p.51- 52: Complexo de vira-latas. 
capacidade de realização? Teríamos aptidão e atitude para concretizar a laboração da matriz econômica de independência dos clubes?

Em 1895, o Brasil já se encontrava em período de vasta imigração italiana iniciada em 1880, que contribuiu fortemente na introdução e popularização do futebol. Em 1901, o Brasil registrou o número de 17.801.245 habitantes, com um PIB de $R \$ 9.184$ milhões e PIB per capita de $R \$ 516$ (em reais de 1999) ${ }^{5}$. O país partia em busca do respectivo desenvolvimento industrial após ter enfrentado importantes mudanças sociais como a consolidação do fim da colonização, a abolição da escravidão, o crescimento da agricultura e exportação de produtos primários, a entrada de capital estrangeiro e relevante participação dos imigrantes. Os italianos, desde 1880 e os japoneses, a partir de 1908, exerceram papel essencial na aceleração do crescimento da cidade de São Paul. Italianos e espanhóis foram determinantes na gênese dos clubes de futebol em São Paulo, sobretudo no Palestra Italia ${ }^{6}$ e no Sport Clube Corinthians Paulista ${ }^{7}$, este com nome inspirado no clube inglês Corinthians Casuals, mas nascido sob a presidência de dois descendentes de italianos, Miguel Battaglia e Alexandre Magnani, e com vários fundadores espanhóis.

Os japoneses não se integram de pronto ao futebol, todavia, mais adiante, no pós-guerra, os nisseis aderem ao esporte e a maioria passa a torcer pela Sociedade Esportiva Palmeiras.

Os imigrantes, em busca de socialização, além da participação na fundação das agremiações futebolísticas, formaram contingentes básicos no universo de torcedores, consagrando a popularização do esporte no Brasil.

Na obra Corinthians e Palestra Italia: Futebol em Terras Bandeirantes, Alfredo Oscar Salum destaca o papel dos imigrantes na relação entre o desenvolvimento dos esportes e o crescimento da cidade de São Paulo:

5 Fonte: IBGE - Estatísticas do Século XX - Séries Históricas https://seculoxx.ibge.gov.br/economicas/contas-nacionais

6 "Apesar de o Palmeiras ainda ser conhecido como um clube ligado à colônia italiana, sua torcida reflete a formação multiétnica do País." (SALUM, 2015)

7 "O Corinthians Paulista reuniu, já nos primeiros anos de existência, elementos de diversos grupos étnicos como italianos, espanhóis, árabes, portugueses e alemães, que se uniram aos brasileiros em nome de uma paixão: o futebol." (SALUM, 2015) 
"O desenvolvimento dos esportes acompanhava o crescimento da cidade de São Paulo, esta tinha em 1870 cerca de setenta mil habitantes e experimentou, a partir dessa época,uma grande expansão populacional em função da imigração europeia e do deslocamento dos antigos escravos. Em 1910 já estava estimada em quatrocentos e cinquenta mil habitantes, dos quais cerca de cinquenta por cento eram imigrantes, fato que denotava as transformações que estavam ocorrendo (...)". (SALUM, 2015, p.17)

O desenvolvimento da história econômica dos clubes no Brasil, até 2007, indicou escassas esperanças e motivadas razões para acreditarmos que os clubes não venceriam o obstáculo da desorganização administrativa. Vagamos do amadorismo quase absoluto para o semiamadorismo, onde os principais dirigentes tentaram impedir a implantação do profissionalismo, em grande parte para cercear a participação de atletas oriundos dos estratos populares, restringindo-a aos atletas com condições financeiras que podiam praticá-lo sem remuneração. Patinamos em profissionalismo incipiente depois de vencida a batalha acima aludida, o que só ocorreu em 1937, quando a Confederação Brasileira de Desportos - CBD ${ }^{8}$, realizou acordo com a dissidente Federação Brasileira de Futebol - FBF $^{9}$, que congregou os clubes que tinham atletas profissionais. Mesmo assim ainda não se chegou ao profissionalismo pleno, permanecemos por longo tempo no semiprofissionalismo, tanto pela formação dos dirigentes como das estruturas em curso. O profissionalismo só veio a ganhar corpo consistente a partir de 1970, com a entrada da televisão e a compra dos direitos de transmissão, ocorrendo de modo gradual, lento e de forma incompleta, por conta da debilidade financeira dos nossos clubes.

O início oficial do profissionalismo, em 1937, se dá em pleno desenvolvimento do processo de mudança na economia engendrado pela "Revolução de 1930", marco relevante na história do país. Dois trabalhos transformaram-se em referências na historiografia econômica sobre o período, conforme aponta Pedro Cezar Dutra Fonseca, em trabalho denominado "A Revolução de 1930 e a

${ }^{8}$ CBD - Confederação Brasileira de Desportos, fundada em 1914 e criada com a missão de fomentar toda a prática desportiva no país, foi a entidade brasileira responsável pela organização do esporte nacional.

${ }^{9} \mathrm{FBF}$ - Federação Brasileira de Futebol (antiga CBD) é a entidade atualmente responsável pela organização de campeonatos de alcance nacional, embora em sua criação pretendesse ser o principal órgão do futebol brasileiro para organização de campeonatos nacionais e representação em entidades internacionais. 
Economia Brasileira": "Formação Econômica do Brasil", de Celso Furtado (1959) e "A Revolução de 1930", de Boris Fausto (1970). Segundo Pedro Cezar, Furtado defendeu que a política de intervenção governamental com desvalorização cambial, expansão da oferta monetária, retenção e queima dos estoques de café, suscitou como produto a sustentação da renda nominal, antecipando-se às recomendações anticíclicas delineadas por Keynes. Além disso, ainda segundo o autor, provocou a transformação estrutural da economia ao deslocar o eixo para a indústria, marcando a passagem do modelo agroexportador para o processo de substituição das importações. Entendo que esse movimento de impacto distinto, não só produziu efeito no campo econômico; ele contemplou o país de modo mais amplo e profundo, criando um ambiente que alcançou todos os setores, na trilha da modernização e implantação de novos marcos.

Embora não se tenha pesquisa específica correlacionando ações no futebol e as trajetórias da política e da economia, é possível notar que o clima gerado por elas produz impacto na atitude dos dirigentes. A profissionalização do futebol, uma luta árdua que possibilitou a entrada de brasileiros pertencentes às classes mais humildes no exercício contínuo do esporte, foi bafejada pela onda da industrialização no sentido de permitir algo novo com identidade menos subalterna e mais promissora. Do ponto de vista econômico, a profissionalização do futebol em 1937 ocorre no princípio de uma queda acentuada do PIB, depois de um crescimento fortíssimo em 1936, e no ano em que houve crise na economia americana. O futebol se liberta do amadorismo oficialmente, não na prática, impulsionado pelo clima da transformação estrutural que coloca a indústria como centro dinâmico. Na sequência, contudo, o ambiente de mudança enfrenta ciclo de queda no crescimento, o que só se reverte em 1944.

Isso colaborou para o efeito que denominamos "antagonismo formal", quando duas forças opostas atuam sobre um mesmo produto, impedindo seu desenvolvimento acentuado, seu crescimento, elevação; e sua queda significativa, decréscimo; o que poderia suscitar rupturas que levassem a mudanças substanciais. Não se evolui o suficiente, nem se tem uma involução que provoque mudança de conduta. É um processo que imprime velocidade com o freio acionado, o objeto em tela anda devagar. Foi isso que aconteceu, o 
profissionalismo da atividade futebol como um todo, não só o exercício da profissão, caminhou com lerdeza, arrastando-se, vítima de todos os interesses que buscavam impedir a libertação do futebol de um sistema semelhante ao velho corporativismo brasileiro, que permite aos oligarcas tomarem o poder sem que sequer monarca algum Ihes tenha concedido privilégios, e, a seguir, continuem no poder controlando a sucessão em processo de "capitanias hereditárias" vigente nos clubes, e regionalmente, por intermédio das respectivas federações estaduais.

A esse desenvolvimento histórico do futebol podemos aplicar, mutatis mutandis, o conceito de "transformismo" definido por Gramsci"10, a ideia de algo que não muda dado o atraso profundo dos elementos que envolvem o ambiente em tela. Uma hegemonia de poder que é conquistada, e se mantém, mesmo que grupos não conservadores o exerçam. Eles não conseguem vencer a inércia.

O futebol cingia-se a entretenimento muito apreciado, mas que não deveria ser tratado como atividade econômica séria e relevante por conta das pessoas que o administravam, da inviabilidade dos clubes e da "incompetência nacional" para produzir algo respeitado mundialmente, mesmo após a conquista de três campeonatos mundiais. O conceito de economia do futebol não era utilizado, nem fazia sentido, seja pela desimportância monetária diante da economia nacional, seja pelo seu gerenciamento incapaz de proporcionar qualquer perspectiva alvissareira. O futebol restava como entretenimento irrelevante economicamente.

Gramsci descreveu o que seria a síntese do transformismo no campo cultural:

\footnotetext{
"Miséria da vida cultural e estreiteza mesquinha da alta cultura: em lugar da história política, a erudição descarnada; em lugar da religião, a superstição; em lugar dos livros e das grandes revistas, o jornal e o panfleto. O dia-a-dia, com seus facciosismos e seus choques personalistas, em lugar da política séria. As universidades, todas as instituições que elaboravam as capacidades intelectuais e técnicas, não permeadas pela vida dos partidos, pelo realismo vivo da vida nacional,
}

\footnotetext{
${ }^{10}$ Antonio Gramsci foi um filósofo marxista, jornalista, crítico literário e político italiano.
} 
formavam quadros nacionais apolíticos, com formação mental puramente retórica, não nacional." (GRAMSCI, 2007) ${ }^{11}$

Transformismo, Hegemonia e Subalternidade no Pensamento de A. Gramsci, apresentado em 2016 no $10^{\circ}$ Encontro de Ciências Políticas em Belo Horizonte: “ de acordo com Gramsci, a classe dominante italiana, quando não teve mais condições de governar a partir de uma ditadura de classe exclusivista, isto é, quando não conseguiu mais manter a dominação apenas entre uma elite restrita, sob pena de ser superada, foi obrigada a delinear uma democracia burguesa". A aliança entre a classe dominante e a burguesia permitiu a manutenção do poder, com uma agenda nova.

O transformismo se caracterizaria pela hegemonia de grupos moderados e conservadores que procuram manter o status quo, monopolizando o poder, evitando que haja ruptura considerada modernizadora ou revolucionária que altere os cânones de poder estabelecidos, assegurando hegemonia da mesma classe dominante e a subalternidade dos estratos dominados. É o que se simplificou na expressão "para que as coisas permaneçam iguais, é preciso que tudo mude", do discurso de Tancredi, Príncipe de Falconeri, em II Gattopardo, de Giuseppe Tomasi di Lampedusa. No transformismo não há cooptação, o estamento que se encontra no poder não compra nem suborna outro grupo social ou econômico para tê-lo sob controle. Ele incorpora algumas demandas do grupo ascendente, que se descola da maioria dominante como a burguesia o fez com relação à aristocracia, modifica a agenda do poder por intermédio da negociação, e por um processo de mudança de pautas trabalhadas de modo semelhante ao reformismo, que pretende executar alterações sem revolução, sem quebra da ordem estabelecida, de modo que a classe ascendente assuma parte do poder sem retirar do centro do cenário quem já o detinha. Uma forma de composição.

Como na análise de Gramsci sobre a história política da Itália, no futebol brasileiro também ocorreu uma aliança da "aristocracia" no sentido de elite comandante, com um segmento pseudomodernizante, no fundo conservador: dirigentes de federações e de alguns clubes, que constituíram a "burguesia do

${ }^{11}$ GRAMSCI, Antonio. Cadernos do Cárcere. Volume 3. Rio de Janeiro: Ed. Civilização Brasileira, 2007. 
futebol", trazendo elementos aparentemente "modernos" sustentados por ações, muitas, copiadas do exterior, aplicadas "convenientemente", a sugerir impressão de mudança, porém com o objetivo de conservar o poder nas federações e nas direções de clube. Isso aconteceu mais declaradamente sob a égide de João Havellange. Tal quadro ocorre até hoje na Confederação Brasileira de Futebol $\mathrm{CBF}^{12}$, onde as federações têm maior peso eleitoral do que os clubes, e para alguém poder se candidatar à respectiva presidência, há necessidade de pelo menos 8 assinaturas de presidentes das tais federações, que são os pilares básicos do arcaísmo e da dependência financeira dos clubes em nosso futebol. A subalternidade do conjunto de dirigentes de clubes é fator crucial para a manutenção da hegemonia da "classe dominante": os dirigentes da CBF, que se mantêm no cargo por anos a fio, criando uma espécie de "corte aristocrática", e na negociação com a "burguesia" do futebol, que são os dirigentes de clubes e federações, que conservam o poder alterando a agenda e normas, sem modificar os pilares básicos da administração. A manutenção do calendário nacional de futebol conservando os campeonatos estaduais, os sucessivos perdões às dívidas dos clubes e, mais recentemente a discussão sobre a inclusão do VAR, o vídeoárbitro, são exemplos. O futebol brasileiro poderia quebrar esse ciclo de mudança política e de restrição de desenvolvimento e atingir a independência e autonomia dos clubes? Ou as mudanças efetuadas se destinam a "deixar tudo como está"?

O processo histórico mostrou, e a nossa pesquisa argumenta, que sem o rompimento das amarras financeiras dos clubes, não. Sem a criação de uma economia de futebol forte e permanente, sem uma matriz inserida nessa economia, que dê ao clube sua possibilidade de alforria, é praticamente impossível. O quadro descortinado, mesmo em período considerado de profissionalismo pleno, era desalentador. Enxergava-se a dependência persistente e crônica com relação aos direitos de transmissão de TV, que passaram a ser o grande financiador do futebol, elidindo e até tornando marginais as receitas resultantes dos estádios. Os recursos da TV sobrelevaram-se a tal ponto, de modo a representar mais de $50 \%$ do faturamento da maioria dos clubes, e estes, endividados e com presidentes eleitos com mandatos curtos de dois a três anos, no máximo, submetiam-se 
inexoravelmente. Os presidentes assumem a direção de instituições praticamente "quebradas" financeiramente e com alta cobrança da torcida por resultados em curto prazo, restando a eles a antecipação da cota de TV, tornando-os caudatários cativos dos donos desses direitos, impossibilitados de buscarem receitas novas, condenados a regime de sobrevivência básica, descrito popularmente "da mão para a boca": pegar o dinheiro da TV para pagar compromissos vencidos. A outra alternativa era vender jogadores, dilapidando o capital técnico e desfazendo a capacidade de consolidar a marca, a depender da existência de atletas vendáveis. Diante de tal quadro, a expectativa sempre foi desalentadora. E,pior, a alimentar conformismo profundo, subserviência imobilizadora, uma estabilidade na mediocridade, onde o antagonismo formal cumpria papel devastador ao impedir os clubes de irromper rumo à independência financeira. Um círculo vicioso inarredável.

A demanda efetiva da economia do futebol se dava de forma a não permitir o progresso econômico. Tanto a componente do consumo, no caso, por parte dos torcedores, como a de investimento, que os agentes deveriam fazer, ficavam estagnadas em patamar insuficiente. A economia do futebol não se desenvolvia. Dessa forma, mesmo em tempos bem recentes, as perspectivas de autonomia financeira e de estabilização econômica não eram vislumbradas e a procura por equação solucionadora persistia. Qual seria o ativo que poderia resolver essa equação?

A Copa do Mundo trouxe a necessidade de estádios com "Padrão FIFA", e mesmo aqueles que não eram cogitados para sediarem jogos da Copa de 2014 precisavam ter tal padrão para, depois dela, poderem concorrer na organização de jogos e eventos. O estádio-arquibancada é aquele construído com intuito exclusivo de oferecer ao torcedor a possibilidade de assistir jogos de futebol. Não tem como focos prioritários a segurança, o conforto, nem a acessibilidade. Possui serviços precários e reduzidos de alimentação e número escasso de banheiros, apenas 0 imprescindível. Neste ponto, a destacar para efeito comparativo, o velho Parque Antarctica oferecia aos torcedores apenas 8 banheiros, enquanto o moderno Allianz Parque está equipado com 63. O estádio-arquibancada se fia no "torcedor apaixonado" que acompanha o time em qualquer lugar, sempre disposto a assisti- 
lo, quer jogando fora, quer atuando "em casa", no seu próprio estádio, ainda que necessite se sacrificar para isso. Ao contrário, o estádio-shopping é planejado para o torcedor cliente, perfeitamente exemplificado pelo Allianz Parque. Tem lanchonetes, restaurante, lojas, academia de ginástica, é multiuso, e a serventia como casa de espetáculos para "shows" e eventos recebe destaque especial como fator para se auferir novas receitas, propulsionando sua rentabilidade de modo significativo. Possui estacionamento, os assentos têm "Padrão FIFA", sendo mais largos e confortáveis, e os banheiros são qualificados.

A trajetória da arquibancada para o shopping é o cenário de fundo da tese. A impulsioná-la está a questão financeira dos clubes, com a busca de melhores condições de desempenho esportivo, e os mais ousados, na conquista do estágio de autodeterminação. $O$ estádio-shopping é um desdobramento do estádio com Padrão FIFA. É a aplicação do "Padrão FIFA" para o aspecto comercial de consumo. Trata-se do padrão multiuso, que provia o estádio de elementos complementares para atração de receitas e de condições para seduzir o novo usuário, que não se constitui mais no torcedor apaixonado, que vai a qualquer lugar, o "até a pé nós iremos, para o que der e vier", consagrado por Lupicínio Rodrigues no hino do Grêmio Foot-ball Porto Alegrense. O estádio-shopping precisa levar em conta as idiossincrasias e demandas do torcedor cliente, que deseja estacionamento próximo, facilidade para compra de ingresso e acesso ao estádio, lugar marcado, acesso aos produtos que o clube comercializa, conforto e alimentação condizente. Por sua vez, o empreendedor que se dispõe a financiar tal estádio deseja o retorno do investimento e auferir lucro, demandando condições para realizar espetáculos, eventos e instalar lojas e serviços. O estádio se transforma em ativo financeiro gerador de receitas.

\section{TRATAMENTO METODOLÓGICO}

O tratamento metodológico escolhido seguiu a indicação do nosso orientador: tratando-se de pesquisa sobre Economia, no caso, Economia do Futebol e o papel do estádio Allianz Parque na matriz econômica do clube, possuindo fundamentação estatística, utilizaremos ferramentas da Quantificação, com inventário de fontes e, portanto, da História Quantitativa. Dessa forma, iremos nos valer de todos os recursos, métodos e técnicas de tratamento utilizadas pelo 
quantitavismo, cabíveis no trabalho. Vamos nos basear em série de dados por intermédio de gráficos e tabelas. Contudo, não nos ateremos ao conjunto estatístico pesquisado, incluiremos a problematização da questão-chave, a matriz econômica surgida com a ereção do Allianz Parque.

Ressalte-se as claras lacunas existentes no conjunto de dados oficiais dos estádios e a relativa importância dada pelos clubes a essas informações. As sínteses dos capítulos serão apresentadas em prosseguimento para facilitar o descortino do trabalho.

O capítulo I contempla uma sinopse do surgimento dos estádios de futebol e a forma como nascem e são construídos, a seguir a constituição do que denominamos estádio-arquibancada, a explicitar o vínculo entre esse tipo de estádio e o torcedor. No capítulo é descrita a relação entre o estádio-arquibancada e o torcedor-apaixonado, que o frequenta em quaisquer condições para assistir o clube do coração. Nessa trilha irrompe o Parque Antacrtica, gênese do Palestra Italia ${ }^{13}$, que é considerado na sequência, bem como a reforma que faz aparecer o epíteto Jardim Suspenso, procurando realizar paralelo possível com a economia do país a cada tempo. O capítulo se encerra com a demolição do Jardim Suspenso abrindo o espaço para o início da construção do Allianz Parque, inserido no desenvolvimento já estabelecido da Economia do Futebol.

O capítulo II procura mostrar essa nova economia com a transformação ocorrida no mundo todo, o casamento entre indústria do entretenimento e geração de receitas alcançando valores significativos; o impacto causado, os novos atores que entram em cena, a financeirização do futebol e a relação com os estádios como centros geradores de receitas.

O capítulo III refere-se à história dos estádios com esse novo papel de ativos econômicos, mostrando a transformação do estádio-arquibancada em estádioshopping, a respectiva caracterização, a Copa do Mundo de 2014 no Brasil como fator desencadeante dos novos estádios padrão-FIFA, suscitando o nascimento do Allianz Parque, fulcro desse trabalho, com o respectivo impacto provocado na

${ }^{12}$ A grafia Palestra "Italia" (sem acento) está correta por refletir o nome original do clube, em língua italiana. 
matriz econômica da Sociedade Esportiva Palmeiras. Em sua conclusão, o capítulo alude à necessidade de fatores adicionais para a consolidação da matriz e a perenidade da independência econômica do clube.

O capítulo IV apresenta gráficos, tabelas e publicações que permitem o cotejamento direto entre o Palestra Italia e Allianz Parque na produção de receitas para o clube.

No capítulo $\mathrm{V}$ ressalta-se a peculiaridade dos objetivos de um clube de futebol confrontado com as exigências da nova economia, enveredando para a discussão sobre os modelos de gestão e suas implicações. Observa-se que o estádio, no caso, o Allianz Parque, não é suficiente para assegurar o processo de autodeterminação e soberania econômica, trazendo à tona a necessidade de pesquisa de modelos de governança e o estudo sobre a incidência do fator humano incutidos no trabalho de gestão do ativo e sua adequação à realidade administrativa e política do clube. O capítulo procura avançar na discussão da forma possível de mensuração da eficiência e eficácia da matriz econômica, estudando um conceito utilizado para o acompanhamento de instituições que não se limitam tão-somente à busca de lucro, caso da Sociedade Esportiva Palmeiras, recorte de nosso trabalho. A conclusão do capítulo apresenta para avaliação e estudo mais aprofundado, um mapa estratégico que possibilite a inclusão desses aspectos no estudo da matriz proporcionada pelo Allianz Parque. Por fim, enseja a importância da comparação com outros modelos.

No capítulo VI desenvolve-se essa aferição com as modelagens constitutivas de utilização e gestão de estádios como Maracanã, Arena Corinthians e Morumbi, defrontando modelos e consequências, de modo a permitir uma avaliação do Allianz Parque em cenário mais amplo de confronto e conferência.

$\mathrm{Na}$ conclusão procuramos, além de sumarizar os pontos relevantes da pesquisa e do trabalho, acrescer as considerações que ensejam os riscos do modelo, os equívocos cometidos no processo de construção e consolidação do Allianz Parque, riscos endógenos e exógenos, e as necessidades que se mostram preciosas para o funcionamento do modelo. Aí também é reconsiderado o desafio de equilibrar a busca por receita e o acesso dos torcedores com menor renda, que 
também são parte importante do patrimônio do clube, com papel inquestionável na constituição da história e consolidação da instituição e que não podem ter sua participação menoscabada.

Na bibliografia, temos a citada no trabalho (bibliografia de referência) e aquela que foi consultada ao longo de anos, contribuindo para o desenvolvimento do raciocínio e a formulação da presente tese, trazendo elementos conceituais para o pensamento, porém sem transcrições no texto.

Em suma, percorremos o longo percurso da construção das bases econômicas que sustentam os clubes de futebol, tendo como referência o Allianz Parque e seu papel na história econômica da Sociedade Esportiva Palmeiras, que emerge como concretização da matriz de independência financeira a raiar como possibilidade para os outros clubes. Sem negligenciar a indicação das respectivas adequações e a necessidade de enfrentamento de problemas ainda persistentes no modelo.

Tudo isso se inicia com a edificação de locais para que os torcedores pudessem assistir e realizar a paixão pelo futebol. O estádio que, na origem, principia com gente em pé ao redor e poucos assentos, é posteriormente entabulado como estádio-arquibancada, que, sem perder tal condição, se transforma a seguir em monumento arquitetônico, político e de culto a personalidades, construção com aparato de fachada. Tem duplo sentido: entabuar, colocar tábuas, madeira para sentar e pôr ordem.

Para concluir, é preciso levar em conta as interações sociais que ocorrem dentro do processo descrito, elas não podem ser desprezadas e constituem parte a considerar na consolidação do estádio como ativo financeiro. Acrescente-se também o avanço da tecnologia, os casos paralelos na indústria de entretenimento que proporcionaram condições para facilitar o acesso e ocupação do Allianz Parque com a introdução de mecanismos que não existiam anteriormente como os aplicativos, que, contribuíram para o resultado. Ou seja, o papel do Allianz Parque na denominada economia do futebol se beneficiou do avanço incremental estabelecido na indústria do entretenimento e se funda, como não poderia deixar de ser, nas relações sociais presentes no desenvolvimento do processo referido. 
Tudo começou com os estádios. 


\section{CAPÍTULO I - A HISTÓRIA E OS ESTÁDIOS}

\subsection{Os primeiros estádios}

Desde o seu surgimento organizado, os estádios constituíram-se em monumentos do futebol, em ambas acepções do termo: obra construída em homenagem a algo ou alguém e construção majestosa. O Maracanã, no Brasil, é o principal símbolo de tais acepções e conta uma rica história de nosso futebol, que se estende do Estádio Mário Filho ${ }^{14}$ à mais humilde, mas também venerada, praça esportiva do interior brasileiro. Os estádios visavam ser marcos arquitetônicos, ter visibilidade, emanavam poder e glória, sem qualquer preocupação com o aspecto financeiro ${ }^{15}$. Na prática, eram passivos a registrar despesas em todos os dias do ano, com exceção de certos dias de jogos, quando a receita superava a despesa, o que nem sempre ocorria.

A modernidade na economia do futebol no Brasil se deu pelo advento desses estádios padrão-FIFA, o padrão que instituiu um conjunto rigoroso de normas e procedimentos constitutivos nunca antes respeitados no país. Portanto, o ano de 2007 é o marco divisor entre o estádio-arquibancada e o estádio-shopping, permitindo a inserção dos clubes na nova economia do futebol, já em curso no mundo, e que poderá torná-los autossuficientes econômica e financeiramente. Esse modernismo, com o sentido que Raymond Williams explicita em "Política do Modernismo - Contra os Novos Conformistas"16, que tem sido usado como um termo geral desde a década de 1950, de um movimento e momento cultural.

${ }^{14}$ O Estádio Jornalista Mário Filho, mais conhecido como Maracanã - Rio de Janeiro, foi inaugurado em 16 de junho de 1950, tendo sido utilizado na Copa do Mundo de Futebol daquele ano.

${ }^{15}$ MASCARENHAS, BIENENSTEIN e SÁNCHEZ, 2016, p.78: "No Brasil, a influência de ideias fascistas durante o Estado Novo impulsionou as primeiras políticas públicas no setor. O Decreto-Lei n. 3199, de 1941, estabeleceu que o Ministério de Educação e Saúde criaria o Conselho Nacional de Desportos (CND), com a finalidade de 'orientar, fiscalizar e incentivar a prática dos esportes em todo o país'. Tanto a construção do Pacaembu quanto a do Maracanã, grandes equipamentos esportivos públicos, acionaram justificativas apoiadas nesse discurso regenerador do esporte."

${ }^{16}$ WILLIAMS, Raymond. Política do Modernismo. Contra os novos conformistas. São Paulo: Unesp, 2001. 
O Allianz Parque é vislumbrado nesse cenário, mesmo não constando entre os estádios a serem utilizados na Copa do Mundo de 2014. Ele foi erguido no mesmo movimento de estádio padrão-FIFA, porém com uma diretriz constitutiva de se transformar em ativo financeiro da empresa que o constrói, a partir da cessão do direito de superfície realizado pela Sociedade Esportiva Palmeiras. Para esta, ele é a gênese e o catalisador do processo de manutenção na gestão do clube, induzindo a estabilização econômica e a independência financeira.

Nesse sentido, nossa pesquisa procurará mostrar que a gestão dos clubes no futebol brasileiro inicia-se de forma amadora, baseada na vertente lúdica e na inovação que trazia, sustentando-se, a princípio, como evento entre empresas públicas, e depois privadas, sem qualquer preocupação com uma estrutura sistêmica, tratando de colher os frutos da novidade que contemplou os trabalhadores dessas empresas.

O problema a ser pesquisado é como se constituem na sociedade contemporânea os monumentos representados pelos novos estádios na economia do futebol e na cultura brasileira. Portanto, o foco da pesquisa é o processo de constituição e desenvolvimento do Allianz Parque como estádio-shopping e as possíveis conexões comparativas com os antípodas na cidade de São Paulo, a Arena Corinthians e o Morumbi.

O que possibilitou a modernidade na gestão dos clubes foram as leis que organizaram e normatizaram o futebol, iniciadas com Lei Pelé, de 1997, com alguns dispositivos básicos entrando em vigor apenas dois anos depois. A Lei Maguito ${ }^{17}$, referência ao senador Maguito Vilela ${ }^{18}$, de 2000, que arrefeceu e alterou parte da Lei Pelé, tornando-a mais palatável aos órgãos de administração e de prática do futebol. A Lei 10.671, o Estatuto do Torcedor, e suas alterações posteriores; e a Lei 10.672, que altera dispositivos da Lei Pelé, compõem a tríade que constitui o arcabouço jurídico hoje vigente, que regula o futebol. Foi a

\footnotetext{
${ }^{17}$ Lei $n^{\circ}$ 9.981, de 14 de julho de 2000 (Altera dispositivos da Lei $n^{\circ}$ 9.615, de 24 de março de 1998).

Lei no 9.615, de 24 de março de 1998 (Institui normas gerais sobre desporto e dá outras providências), mais conhecida como Lei Pelé.
}

${ }^{18}$ Luiz Alberto Maguito Vilela é advogado e foi Senador no período de 1999 a 2007. 
combinação delas que obrigou os clubes, federações e confederações a um conjunto de procedimentos que permitem realizar um cotejamento com dados oficiais e comparáveis do sistema de gestão dos clubes, com destaque para os balanços, que antes da Lei Pelé, não eram efetuados ou eram realizados fora dos padrões técnicos reconhecidos, e, transformados em obrigatórios com a Lei Pelé e, por fim, definidos conforme padrões do Conselho Federal de Contabilidade pela Lei 10.672/2003.

São essas leis que possibilitam o que definimos como "modernidade na gestão dos clubes de futebol". Além disso, elas ocorreram no âmago de um período em que a imprensa desempenhou um papel essencial na cobrança de novos rumos para um futebol que havia recuperado sua distinção com a conquista da Copa do Mundo de 1994, nos Estados Unidos, a surtir impulso significativo na comunidade do nosso futebol, em busca de alterações que propiciassem estabilidade organizacional aos clubes, matéria relegada a profundo desprezo por parte da Confederação Brasileira de Futebol - CBF.

Porém, é importante notar que a maior semente dos males que infestaram os clubes brasileiros em termos de gestão e finanças foi a inclusão, de forma descuidada, do artigo 217, inciso I, na Constituição Federal de $1988^{19}$, a indicar autonomia das entidades esportivas quanto às respectivas formas de organização e financiamento, equívoco do qual se aproveitaram os dirigentes dos clubes de então, interpretando-o intencionalmente como autonomia plena, que nenhuma instituição possui, nem mesmo a Universidade. Deu-se através de redação astuciosa feita por um advogado ligado aos dirigentes dos clubes esportivos, com a negligência da Comissão responsável pelo texto. Só dez anos depois de vigência do Estatuto do Torcedor, em 2013, é que o Ministro do Supremo Tribunal Federal (STF), Antônio César Peluso, em parecer inequívoco sobre a constitucionalidade do Estatuto (2003), aprovado por unanimidade, derrubou tal interpretação que vários tribunais inferiores assumiram causando um grande mal ao futebol, entre os

19 "Artigo 217: É dever do Estado fomentar práticas desportivas formais e não-formais, como direito de cada um, observados:

Inciso I: a autonomia das entidades desportivas dirigentes e associações, quanto a sua organização e funcionamento; (...)". 
anos de 1988 e 2013. O Estatuto do Torcedor, além do seu mérito, teve esse papel de provocar o esclarecimento.

Falar dos estádios como monumentos do futebol, e em particular como representantes da economia dos clubes, inserida na economia de mercado em curso, é aludir à interação do homem com as relações de uso e de troca que se estabelecem com os objetos. Há um percurso que os leva da pouca relevância como fonte de receita, a um papel onde tal participação cresce, e a renda dos jogos ganham importância, mas sem qualquer cuidado com a segurança e conforto dos torcedores, para, outra vez, declinar e ser menoscabada, com a preferência que os clubes passam a dar pela venda dos seus jogadores e pelas receitas das redes de comunicação, que têm uma notória propulsão a partir dos anos 70. A inauguração do Allianz Parque o transforma em monumento econômico-financeiro, fazendo o clube superar a dependência histórica, de décadas, dos direitos de transmissão e da venda de jogadores. Afinal, ao longo da história, a sustentação financeira dos clubes tem sido um campo inexplorado, a submeter dirigentes, analistas, torcedores e simpatizantes a conclusões simplificadoras, sem qualquer base empírica ou estudo mais alentado, contribuindo para a consolidação de cenário obscuro que impede a evolução do futebol brasileiro. O estádio como monumento assoma de forma decisiva para narrar a trajetória de uma relação que começa como time-torcedor e se transforma em clube (empresa)-cliente, onde a primeira interação cingia-se ao estádio-arquibancada, e a atual, ao estádio-shopping.

\subsection{Do Parque Antarctica ao Allianz Parque}

\subsubsection{O Parque Antarctica}

O estádio Palestra Italia é símbolo e representante do estádio-arquibancada definido na Introdução do trabalho. Sua história remonta ao final do século XIX e tem origem na Companhia Antarctica Paulista, indústria fabricante, à época, de gelo e derivados de carne suína.

No início do século XX a Companhia Antarctica implantou o Parque da Antarctica, uma significativa área verde com cerca de $300.000 \mathrm{~m}^{2}$, dotada de equipamentos de lazer com restaurantes, parque infantil, salões para festas e 
espaços para a prática esportiva, incluindo um dos primeiros campos de futebol com dimensões oficiais na cidade de São Paulo20.

Em 3 de maio de 1902, ainda com o nome de "Parque da Antarctica", disputou-se a primeira partida de futebol de um campeonato no Brasil, na abertura do Campeonato Paulista. Uma arquibancada de madeira, ícone do estádioarquibancada, oferecia os primeiros lugares com assentos aos torcedores, que estavam acostumados a acompanhar a partida em volta do gramado.

Antes de se consolidar como patrimônio do Palestra Italia - Società Sportiva, o campo de futebol do "Parque da Antarctica" foi arrendado e por vezes sublocado a diversas agremiações, tendo também seu uso compartilhado com a Societá Sportiva Palestra Italia ${ }^{21}$, que utilizava o espaço nas tardes de terça, quinta, sábado e domingo. Na segunda década do século XX o Parque Antarctica era um dos maiores palcos do futebol paulista, com possibilidade de oferecer cerca de 15 mil lugares, contando arquibancada e demais espaços disponíveis. Em 1920 concretizou-se a compra, pelo Palestra Italia, do terreno onde se situava o campo de futebol do Parque da Antarctica. A aquisição contou com a participação decisiva da Companhia Matarazzo S.A. ${ }^{22}$, que com avançada visão holística relativa à produtividade, enxergou nessa participação uma boa forma de juntar trabalho, moradia e lazer para seus trabalhadores. Com isso, contribuiu de forma decisiva para a consolidação da comunidade italiana em São Paulo. Com essa aquisição o Parque Antarctica passou a fazer parte da história do "Palestra Italia", que colocou

20 SALUM, 2015, p.25: "Não sem razão, empresas como a Companhia Antarctica colocaram à disposição seu terreno para construção de praças esportivas."

${ }^{21}$ ARAUJO, 2000, p.83: "O Palestra Itália foi fundado em 26 de agosto de 1914, após a publicação de uma carta, em 14 de agosto, seguida de uma convocação no dia 19, no Fanfulla (jornal de maior circulação em São Paulo na década de 1920, em língua italiana, dirigido aos imigrantes italianos). Todos os imigrantes da cidade de São Paulo interessados na fundação de um quadro italiano de futebol foram convocados a participar de um evento no qual decidiriam sua fundação, definiriam seu nome e marcariam a data da sua oficialização. Em 26 de agosto, na presença de 46 pessoas, oficializou-se a existência do Palestra Itália. Seu objetivo era estruturar um time de futebol representativo da comunidade italiana fixada na cidade, justamente quando esta começava a se organizar no incipiente meio esportivo brasileiro, reunindo simpatizantes e jogadores de origem italiana espalhados pelos inúmeros clubes e times de futebol de São Paulo."

${ }^{22}$ As Indústrias Reunidas Fábricas Matarazzo (IRFM), com sede na cidade de São Paulo, foram o maior grupo empresarial da América Latina, chegando a englobar em torno de 350 empresas de diversos ramos, como têxtil, químico, comercial, bancário e alimentício. 
em prática planos ousados em busca de um estádio mais confortável e com maior capacidade de público, em movimento acalentado pelo período de transição econômica e social do país, que se movia do modelo primário exportador em direção à industrialização e à urbanização.

\section{Figura 01 - Parque Antarctica em 1922}

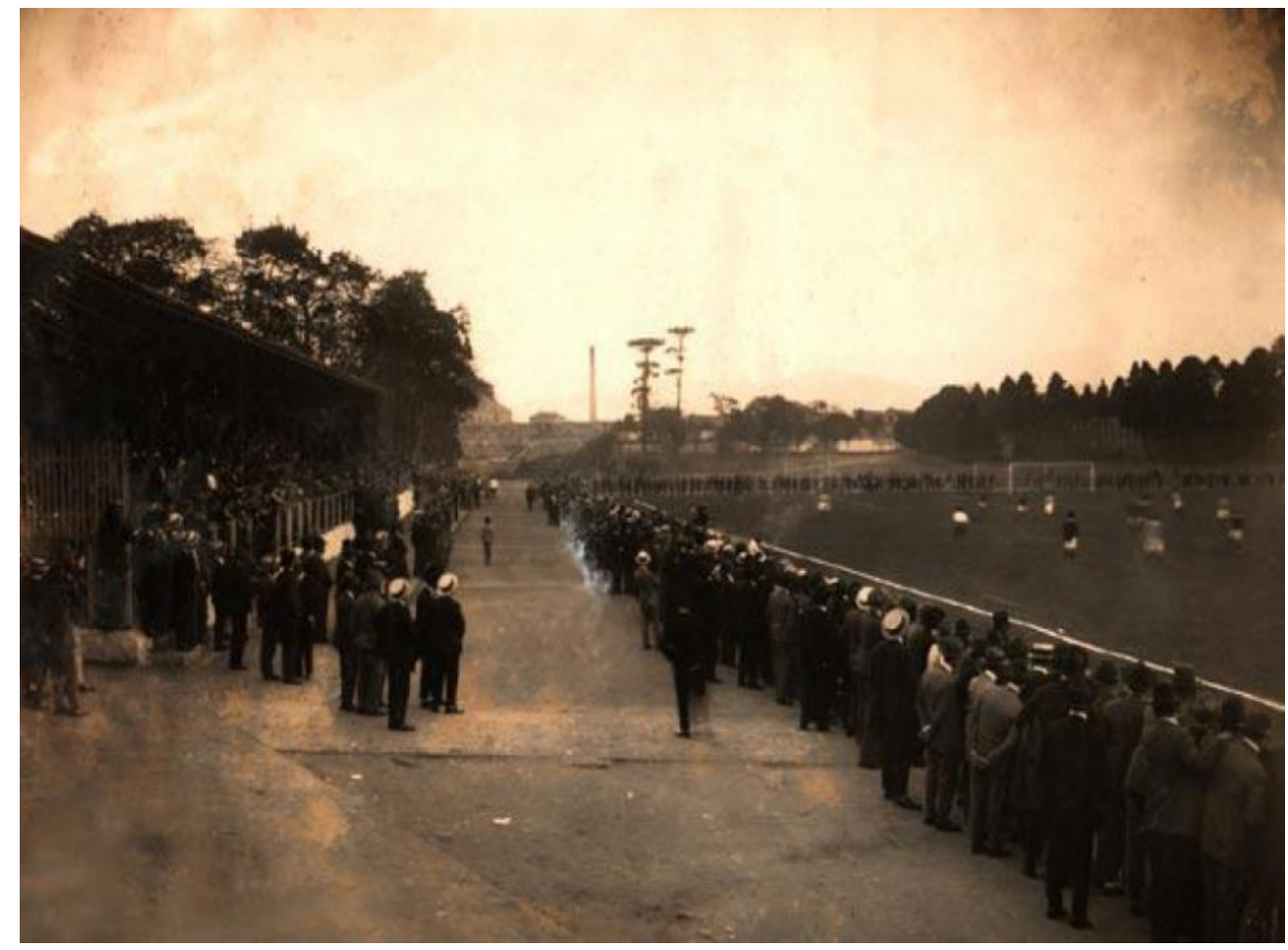

Fonte: (Sociedade Esportiva Palmeiras) acesso em 10/03/2018

Wilson Cano 23 , em artigo "Da década de 1920 à de 1930: Transição Rumo à Crise e à Industrialização no Brasil", mostra tal processo de transição do modelo exportador cafeeiro paulista rumo ao que chamou de "crescimento para dentro", desencadeado a partir da Crise de 1929 e da Revolução de 1930, que passou da considerada industrialização restringida, ainda atada aos liames do padrão exportador, ganhando, a partir de então, outra dinâmica.

"Transitamos assim do velho padrão primário exportador, onde o complexo cafeeiro paulista predominava, para o da industrialização que se firmou a partir de 1930" (CANO, 2012).

23 CANO, Wilson. Da década de 1920 à de 1930: Transição Rumo à Crise e à Industrialização no Brasil. Brasília: Economia, 2012. 


\subsubsection{O Palestra Italia}

Esse movimento no sentido da industrialização, essa nova dinâmica propalada por Wilson Cano, tangeu os diretores palestrinos a efetuar um salto de qualidade na arena esportiva. Estimulados pelo espírito da época, os dirigentes palestrinos reformaram o estádio, que passou de 15 mil para 30 mil espectadores, dobrando com ousadia sua capacidade, no ritmo da urbanização de São Paulo, e, em 13 de agosto de 1933 foi inaugurado o Stadium Palestra Italia, com vitória do Palestra sobre o Bangu ${ }^{24}$ por $6 \times 0$.

\section{Tabela 01 - Dados do Estádio Palestra Italia}

\begin{tabular}{|c|c|}
\hline \multicolumn{2}{|r|}{ Palestra Italia } \\
\hline Estacionamento & Não \\
\hline Capacidade Oficial & 27.650 \\
\hline Assentos & 27.650 lugares \\
\hline $\begin{array}{l}\text { Shows - } \\
\text { Espetáculos }\end{array}$ & Não \\
\hline Teatro & Não \\
\hline $\begin{array}{l}\text { Centro de } \\
\text { Convenções }\end{array}$ & Não \\
\hline Vestiários & 2 \\
\hline Elevadores & Não \\
\hline Escadas & Não \\
\hline Banheiros & 8 banheiros \\
\hline Inauguração & 7 de setembro de 1964 \\
\hline $\begin{array}{l}\text { Dados da } \\
\text { Construção }\end{array}$ & $\begin{array}{l}\text { Data da Construção: Campo: } 1902 \text { / Estádio: } 1933 \\
\text { Nome: Estádio Palestra Italia } \\
\text { Nome Popular: Parque Antártica } \\
\text { Local: Rua Turiaçu, São Paulo, SP, Brasil } \\
\text { Proprietário: Palmeiras } \\
\text { Mandante: Palmeiras } \\
\text { Custo: } 500 \text { contos de réis } \\
\text { Remodelado: década de } 1950 \text { e } 2008 \\
\text { Expandido: década de } 1990 \\
\text { Capacidade para } 31.900 \text { lugares } \\
\text { Fechado: } 10 \text { de julho de } 2010 \text {, para a construção do Allianz } \\
\text { Parque } \\
\text { Demolido: } 2011\end{array}$ \\
\hline
\end{tabular}

${ }^{24}$ Bangu Atlético Clube é uma agremiação esportiva brasileira sediada no bairro Bangu, cidade do Rio de Janeiro. Fundado em 1904. 


\begin{tabular}{|l|l|}
\hline Partida inaugural & $\begin{array}{l}\text { Primeiro jogo como proprietário: 16 de maio de } 1920 \\
\text { (Palestra Italia } 7 \text { x } 0 \text { Mackenzie) } \\
\text { Inauguração oficial: } 13 \text { de agosto de } 1933 \\
\text { (Palestra Italia } 6 \text { x } 0 \text { Bangu) } \\
\text { Primeiro jogo no Palestra Italia (pós-reformas): } 7 \text { de } \\
\text { setembro de 1964 } \\
\text { (Palmeiras 2 x } 0 \text { Esportiva de Guaratinguetá) }\end{array}$ \\
\hline Partida Final & $\begin{array}{l}\text { Data: } 9 \text { de julho de 2010 } \\
\text { Palmeiras 0 } 02 \text { Boca Juniors }\end{array}$ \\
\hline
\end{tabular}

Fonte:Sociedade Esportiva Palmeiras-www.palmeiras.com.br - acesso em 10/03/2018

Figura 02 - Imagem panorâmica do estádio em 1936

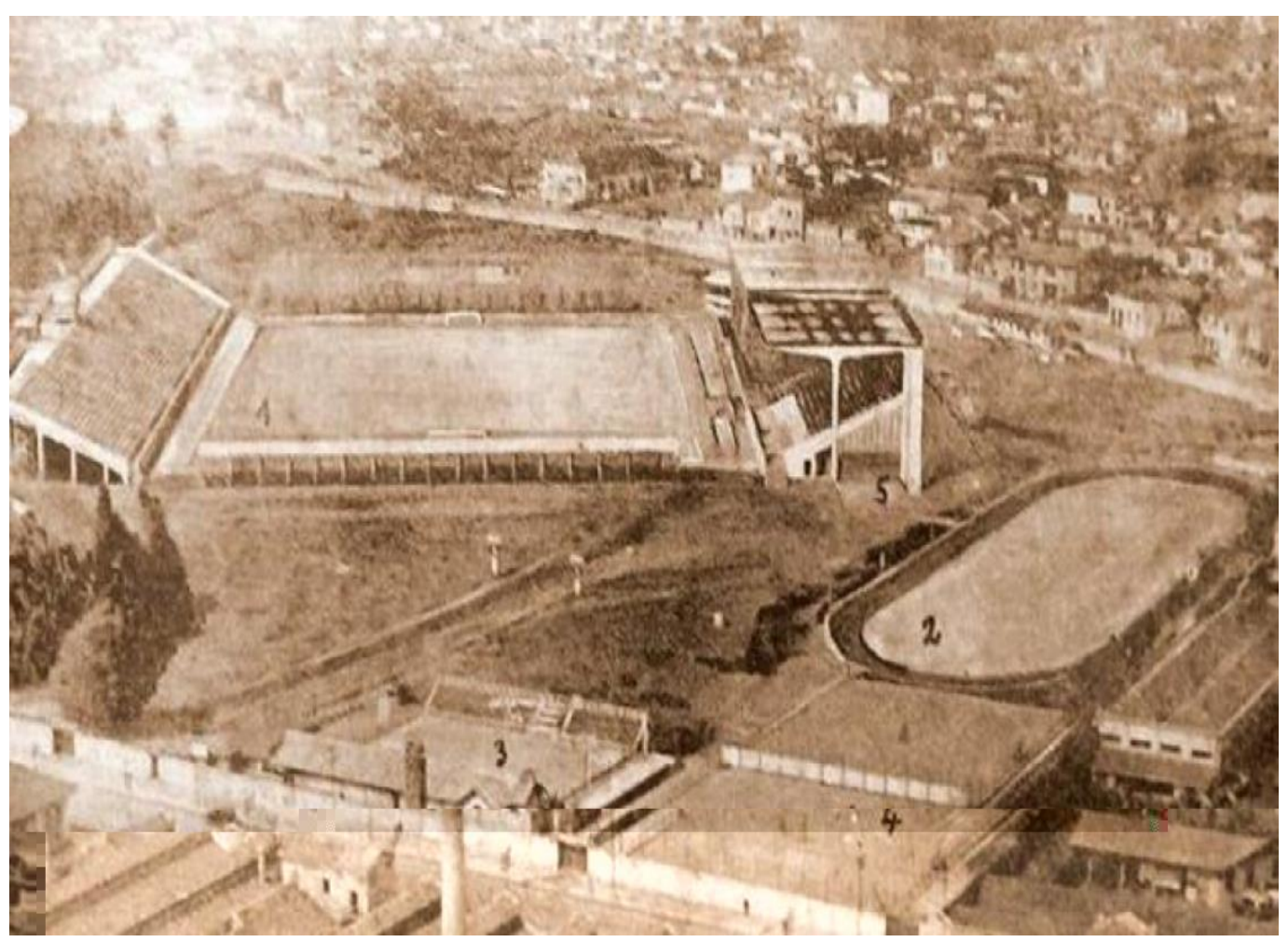

Fonte: (Sociedade Esportiva Palmeiras) acesso em 10/03/2018

Ao longo do trabalho, observar-se-á que além da repercussão direta da economia do país na economia do futebol, há um peso significativo do ambiente gerado pela perspectiva de crescimento do Brasil a atuar nas iniciativas voltadas ao futebol, visando ao progresso dos fatores extracampo, que sempre foram o ponto frágil para o desenvolvimento do esporte. Porém, importante notar que o conceito de conforto que se tinha na época aludida era bem diferente do atual. O estádioarquibancada, referência do estádio que os dirigentes tinham então, considerava avanço ter mais lugares, acima de tudo, reservando alguns espaços, escassos, 
para um público de melhor poder aquisitivo. O Estádio Municipal do Pacaembu25, construído em 1940 para ser o grande estádio do futebol paulista, possui até hoje, apenas 2500 assentos numerados cobertos. O estádio-arquibancada foi sempre a construção imaginada pelos dirigentes, por longo período, deixando de ser a referência básica apenas quando o Brasil foi escolhido para sediar a Copa de 2014.

\subsubsection{O Jardim Suspenso}

Acompanhando o espírito desenvolvimentista que se instalou no governo Juscelino Kubitschek ${ }^{26}$, no período em que o Brasil era o país com maior crescimento no mundo, com taxas médias de $7,5 \%$ ao ano, suscitando entusiasmo empreendedor e a busca de condições melhores de receita por intermédio do aumento de lugares para os torcedores, o Palmeiras, outra vez, projetou um outro salto de qualidade para seu estádio. Com ideia considerada revolucionária no momento, através do projeto liderado pelo engenheiro Clóvis Felipe Olga, que aumentava com ousadia a capacidade para 70.000 lugares, superando 0 Pacaembu, além de trazer solução técnica a resolver o frequente problema de enchentes que assolava a região, ao aplicar uma elevação de três metros acima do nível do solo e formar um fosso em volta do gramado. Emergia o conhecido Jardim Suspenso.

25 O Estádio Municipal Paulo Machado de Carvalho, mais conhecido por Estádio do Pacaembu ou simplesmente Pacaembu, é um estádio desportivo localizado na Praça Charles Miller, no final da avenida Pacaembu, no bairro do Pacaembu, zona central da cidade de São Paulo. Foi inaugurado na década de 1940.

${ }^{26}$ Juscelino Kubitschek de Oliveira ocupou a Presidência da República entre 1956 e 1961. 


\section{Figura 03 - 0 Projeto original}

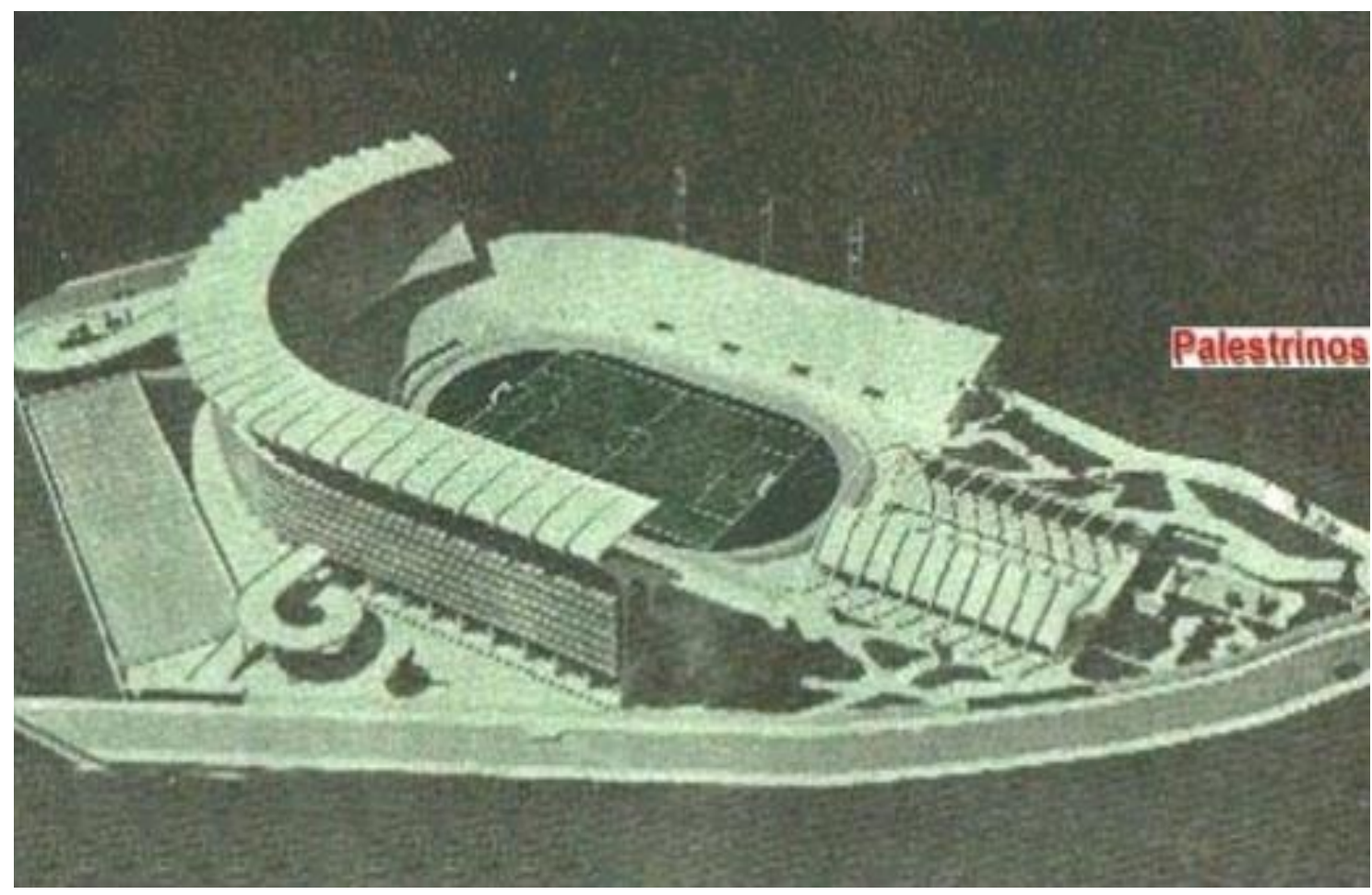

Fonte: Jornal Lance! acesso em 12/03/2018

O projeto não se realizou em sua totalidade por conta das limitações impostas pelo orçamento e foi sendo implantado gradualmente, e concluído só em 1964. Foi o recurso auferido com a venda do jogador Chinesinho ${ }^{27}$ para o Modena ${ }^{28}$, clube italiano, que permitiu a receita necessária para a construção realizada, aquém da prevista, exemplificando como os clubes financiavam seus investimentos. O Jardim Suspenso foi inaugurado em 7 de setembro de 1964, com vitória do Palmeiras sobre a Esportiva de Guaratinguetá29. Esta denominação, Jardim Suspenso, passou a ser epíteto do Estádio Palestra Italia e foi o derradeiro modelo de estádioarquibancada, recebendo sua última partida em 9 de julho de 2010, em jogo em

${ }^{27}$ Sidney Colônia Cunha, mais conhecido como Chinesinho, foi um treinador e futebolista brasileiro que atuava como meia.

${ }^{28}$ Modena Football Club, Modena FC ou simplesmente Modena, clube de futebol italiano fundado em 1912.

${ }^{29}$ A Associação Esportiva Guaratinguetá foi fundada em 1915 na cidade de Guaratinguetá, Estado de São Paulo. 
que o Palmeiras perdeu para o Boca Juniors ${ }^{30}$. Todas as inaugurações foram com vitórias expressivas, a despedida se deu com dolorida derrota.

Figura 04 - Palestra Italia

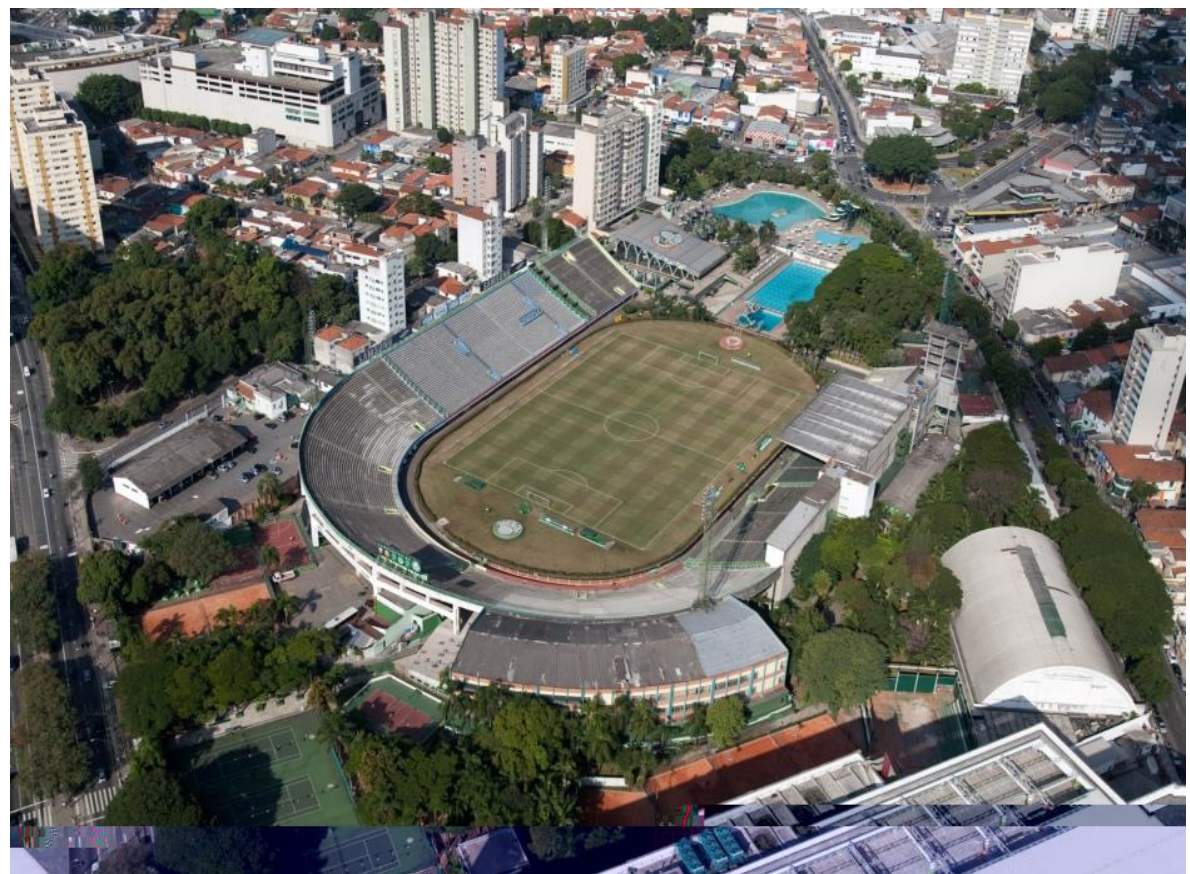

Fonte: (Sociedade Esportiva Palmeiras) acesso em 10/03/2018

\subsubsection{A demolição}

O processo que dá início à construção do Allianz Parque, símbolo do estádioshopping e ponto central do trabalho, é bastante conturbado, ocorrendo em um período de enorme resistência por parte de conselheiros ligados ao ex-presidente Mustafá Contursi Goffar Majzoub31, líder de grupo que se opôs tenazmente ao acordo com a WTorre ${ }^{32}$, que havia adquirido, por 30 anos, o direito de uso de superfíciedo novo estádio. A crise atingiu sua fase mais dramática com a atitude de um conselheiro que se atirou no caminho do trator que iniciaria a obra. $O$ conselheiro José Cyrillo Junior, diretor de obras, teve papel crucial na construção do Allianz Parque ao ordenar o início da demolição do Jardim Suspenso. Houve

30 O Clube Atletico Boca Juniors, conhecido como Boca Juniors ou simplesmente Boca, clube de futebol argentino da cidade de Buenos Aires fundado em 1905.

${ }^{31}$ Mustafá Contursi Goffar Majzoub é um dirigente esportivo brasileiro. Ficou conhecido por ter sido presidente do Palmeiras entre 1993 e início de 2005.

32 WTorre Empreendimentos Imobiliários S.A., ou somente WTorre, é uma empresa de engenharia com sede em São Paulo, capital. 
lapso significativo entre o acordo com a WTorre e a derrubada do Palestra Italia, provocando apreensão e insegurança sobre o cumprimento do contrato com o parceiro do novo estádio. Foi a demolição que afastou de vez e incerteza e marcou a concretização da obra.

Figura 05 - Demolição do Palestra Italia

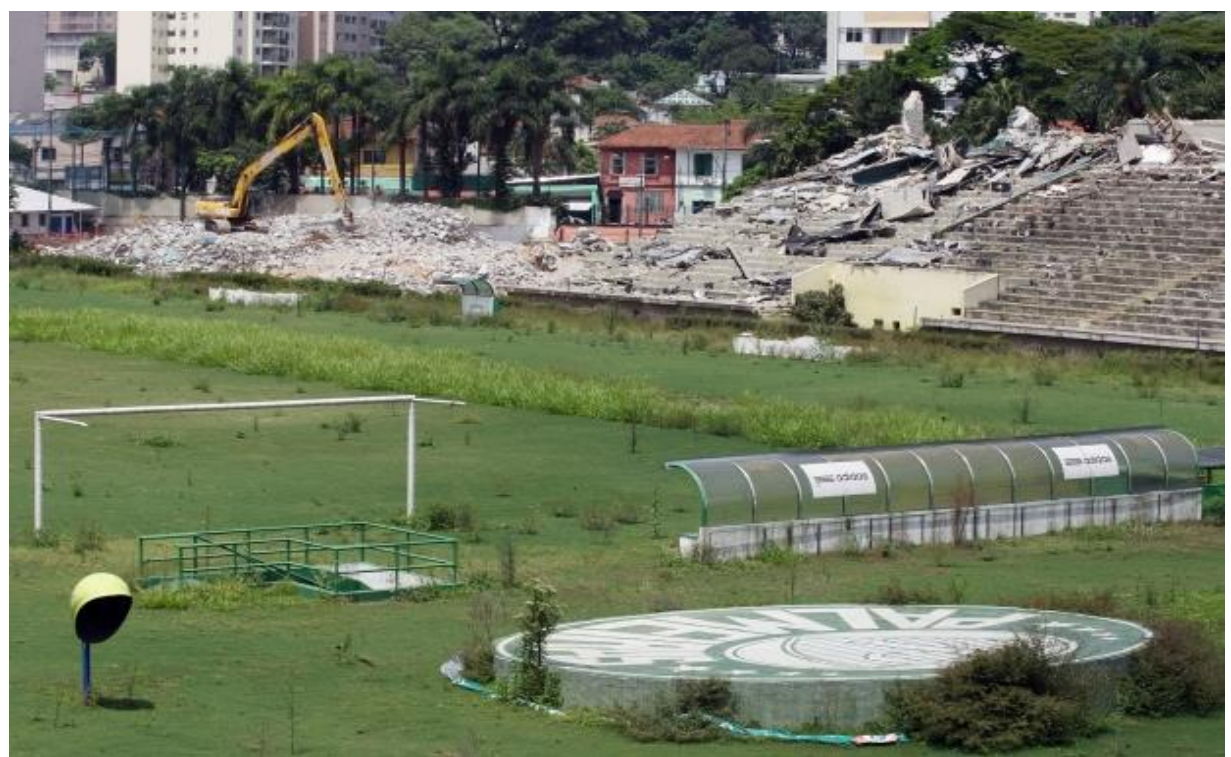

Fonte: Jornal Estadão - www.estadao.com.br - acesso em 05/03/2018

Também tiveram papéis fundamentais na consecução do projeto o presidente Affonso Della Monica, que precisou conduzir com extrema habilidade as aprovações no Conselho Deliberativo e no Conselho de Orientação Fiscal, pela forte resistência por parte de conselheiros. Neste contexto, saía de cena o estádioarquibancada e assomava o estádio-shopping, criando as condições econômicofinanceiras para o surgimento de uma nova matriz econômica sustentável e exequível para a Sociedade Esportiva Palmeiras, modelo aplicável a outros clubes do Brasil, novo patamar na economia do futebol.

Desde sua inauguração em 1964 até a demolição em 2011 para construção do Allianz Parque, o Palestra Italia, com capacidade máxima para 27.650 lugares e apenas 8 banheiros (tabela 1), representou o modelo de estádio refletido pelo momento econômico vivenciado no país, o estádio-arquibancada, modelo este que só viria a ser alterado com a realização da Copa do Mundo de 2014 no Brasil e 
consequente adoção do Padrão-Fifa, como amplamente explicitado no decorrer do presente trabalho.

\subsection{Sociedade Esportiva Palmeiras}

Os dados a seguir relacionados objetivam demonstrar como evoluiu a arrecadação do clube no período retratado no presente estudo - 2007 a 2010, com o Palestra Italia, até a inauguração do Allianz Parque.

\subsubsection{Público e Renda}

(a) Campeonato Paulista - Palestra Italia

As tabelas abaixo demonstram o público e a renda nos jogos em que o Palmeiras foi mandante, pelo Campeonato Paulista, no período de 2007 a 2010, equivalente aos três últimos anos de funcionamento do Palestra Italia anteriores à demolição que daria origem ao Allianz Parque.

Tabela 02 - Público e Renda - Campeonato Paulista: Palestra Italia 2007 em Mil R\$

\begin{tabular}{|l|c|c|}
\hline \multicolumn{1}{|c|}{$\mathbf{2 0 0 7}$} & $\begin{array}{c}\text { Público } \\
\text { Pagante(pessoas) }\end{array}$ & Renda \\
\hline Palmeiras X Paulista & 14.362 & $\mathrm{R} \$ 215.310$ \\
\hline Palmeiras X Santo André & 22.100 & $\mathrm{R} \$ 383.580$ \\
\hline Palmeiras X Barueri & 16.952 & $\mathrm{R} \$ 249.960$ \\
\hline Palmeiras X Santos & 18.676 & $\mathrm{R} \$ 314.490$ \\
\hline Palmeiras X Rio Claro & 11.632 & $\mathrm{R} \$ 192.015$ \\
\hline Palmeiras X Noroeste & 13.319 & $\mathrm{R} \$ 211.265$ \\
\hline Palmeiras X Juventus & 11.487 & $\mathrm{R} \$ 170.030$ \\
\hline Palmeiras X Marília & 15.221 & $\mathrm{R} \$ 228.425$ \\
\hline Palmeiras X Guaratinguetá & 5.079 & $\mathrm{R} \$ 73.460$ \\
\hline TOTAL & $\mathbf{1 2 8 . 8 2 8}$ & $\mathbf{R} \$ \mathbf{2 . 0 3 8 . 5 3 5}$ \\
\hline Média & $\mathbf{1 4 . 3 1 4}$ & $\mathbf{R} \$ \mathbf{2 2 6 . 5 0 4}$ \\
\hline
\end{tabular}

Fonte:Federação Paulista de Futebol - FPF-www.futebolpaulista.com.br - acesso em 10/03/2018. 
Tabela 03 - Público e Renda - Campeonato Paulista: Palestra Italia 2008 em Mil R\$

\begin{tabular}{|l|c|c|}
\hline \multicolumn{1}{|c|}{2008} & $\begin{array}{c}\text { Público } \\
\text { Pagante(pessoas) }\end{array}$ & Renda \\
\hline Palmeiras X Rio Preto & 23.033 & $\mathrm{R} \$ 563.907$ \\
\hline Palmeiras X Ponte Preta & 13.396 & $\mathrm{R} \$ 357.887$ \\
\hline Palmeiras X Portuguesa & 19.061 & $\mathrm{R} \$ 510.730$ \\
\hline Palmeiras X São Caetano & 23.041 & $\mathrm{R} \$ 624.240$ \\
\hline Palmeiras X São Paulo & 27.680 & $\mathrm{R} \$ 1.144 .355$ \\
\hline Palmeiras X Ponte Preta & 27.927 & $\mathrm{R} \$ 1.433 .350$ \\
\hline TOTAL & $\mathbf{1 3 4 . 1 3 8}$ & $\mathbf{R} \mathbf{4 . 6 3 4 . 4 7 0}$ \\
\hline Média & $\mathbf{2 2 . 3 5 6}$ & $\mathbf{R} \mathbf{7 7 2 . 4 1 1}$ \\
\hline
\end{tabular}

Fonte:Federação Paulista de Futebol - FPF-www.futebolpaulista.com.br - acesso em 10/03/2018.

Tabela 04 - Público e Renda - Campeonato Paulista: Palestra Italia 2009 em Mil R\$

\begin{tabular}{|l|c|c|}
\hline \multicolumn{1}{|c|}{$\mathbf{2 0 0 9}$} & $\begin{array}{c}\text { Público } \\
\text { Pagante(pessoas) }\end{array}$ & Renda \\
\hline Palmeiras X Marília & 7.496 & $\mathrm{R} \$ 150.562,00$ \\
\hline Palmeiras X Noroeste & 6.195 & $\mathrm{R} \$ 184.648,74$ \\
\hline Palmeiras X Santos & 24.515 & $\mathrm{R} \$ 689.985,00$ \\
\hline Palmeiras X Guarani & 11.617 & $\mathrm{R} \$ 330.057,50$ \\
\hline Palmeiras X Barueri & 13.278 & $\mathrm{R} \$ 370.127,50$ \\
\hline Palmeiras X Bragantino & 8.402 & $\mathrm{R} \$ 220.878,74$ \\
\hline Palmeiras X Botafogo & 12.653 & $\mathrm{R} \$ 332.807,97$ \\
\hline Palmeiras X Santos & 26.420 & $\mathrm{R} \$ 1.071 .800,00$ \\
\hline TOTAL & $\mathbf{1 1 0 5 7 6}$ & $\mathbf{R} \$ \mathbf{3 . 3 5 0 . 8 6 7 , 4 5}$ \\
\hline Média & $\mathbf{1 3 . 8 2 2}$ & $\mathbf{R} \mathbf{4 1 8 . 8 5 8 , 4 3}$ \\
\hline
\end{tabular}

Fonte:Federação Paulista de Futebol - FPF-www.futebolpaulista.com.br - acesso em 10/03/2018. 
Tabela 05 - Público e Renda - Campeonato Paulista: Palestra Italia 2010 em Mil R\$

\begin{tabular}{|l|c|c|}
\hline \multicolumn{1}{|c|}{$\mathbf{2 0 1 0}$} & $\begin{array}{c}\text { Público } \\
\text { Pagante(pessoas) }\end{array}$ & Renda \\
\hline Palmeiras X Mogi Mirim & 17.051 & $\mathrm{R} \$ 364.900$ \\
\hline Palmeiras X Ituano & 9.684 & $\mathrm{R} \$ 258.010$ \\
\hline Palmeiras X Portuguesa & 6.533 & $\mathrm{R} \$ 170.917$ \\
\hline Palmeiras X São Caetano & 3.324 & $\mathrm{R} \$ 98.470$ \\
\hline Palmeiras X São Paulo & 13.590 & $\mathrm{R} \$ 390.270$ \\
\hline Palmeiras X Santo André & 3.840 & $\mathrm{R} \$ 109.273$ \\
\hline Palmeiras X Ponte Preta & 17.247 & $\mathrm{R} \$ 479.334$ \\
\hline Palmeiras X Mirassol & 3.764 & $\mathrm{R} \$ 109.558$ \\
\hline Palmeiras X Oeste & 3.560 & $\mathrm{R} \$ 75.382$ \\
\hline TOTAL & $\mathbf{7 8 5 9 3}$ & $\mathbf{R} \mathbf{2 . 0 5 6 . 1 1 4}$ \\
\hline Média & $\mathbf{8 . 7 3 3}$ & $\mathbf{R} \mathbf{2 2 8 . 4 5 7}$ \\
\hline
\end{tabular}

Fonte:Federação Paulista de Futebol - FPF-www.futebolpaulista.com.br - acesso em 10/03/2018.

Os dados apresentados demonstram que o total da renda nas partidas que tiveram a Sociedade Esportiva Palmeiras como mandante no ano de 2007 foi de $\mathrm{R} \$ 2.038 .535,00$, o que corresponde à renda de uma só partida nos anos do Allianz Parque (v. Palmeiras x Atlético PR em 2016 - Tabela 10). No ano de 2008, quando - Palmeiras foi campeão Paulista e disputou a semifinal e a final - partidas especiais com maior renda, a arrecadação de bilheteria em todo o campeonato nas partidas do clube como mandante foi de apenas $\mathrm{R} \$ 4.634 .470,00$, menor que a arrecadação de um único jogo realizado no novo estádio, como a partida entre Palmeiras X Santos pela Copa do Brasil em 2015, cuja renda foi de $R \$$ 5.336.631. O mesmo ocorre nos anos 2009 e 2010, indicando o aumento significativo da receita do clube com bilheteria após a inauguração do novo estádio.

Resta evidenciado, portanto, que o Allianz Parque elevou a média de rendimento com bilheteria nas partidas de futebol com mando do clube para $R \$$ 2.019.255,00 em 2015, R\$ 1.805.876,00 em 2016, $R \$ 1.861 .485,00$ em 2017, $R \$$ 2.105.004,00 em 2018 e R\$1.628,293 em 2019. Em 2014 e 2015 houve um 
acréscimo de aproximadamente $376 \%$ no item arrecadação de jogos, com relação à média do Palestra Italia nos anos referidos.

(b) Campeonato Brasileiro - Palestra Italia

Abaixo apresentamos as tabelas de público e renda do Campeonato Brasileiro no período.

Tabela 06 - Público e Renda - Campeonato Brasileiro: Palestra Italia 2007 em Mil R\$

\begin{tabular}{|c|c|c|}
\hline 2007 & $\begin{array}{c}\text { Público } \\
\text { Pagante(pessoas) }\end{array}$ & Renda \\
\hline Palmeiras X Figueirense & 19.047 & $R \$ 315.165$ \\
\hline Palmeiras X Cruzeiro & 13.381 & $R \$ 199.600$ \\
\hline Palmeiras X Botafogo-RJ & 21.322 & $\mathrm{R} \$ 238.620$ \\
\hline Palmeiras X Atlético-PR & 17.552 & $\mathrm{R} \$ 196.915$ \\
\hline Palmeiras X América-RN & 13.049 & $\mathrm{R} \$ 207.235$ \\
\hline Palmeiras X Santos & 18.662 & $R \$ 307.130$ \\
\hline Palmeiras X Vasco da Gama & 6.389 & $\mathrm{R} \$ 87.760$ \\
\hline Palmeiras X Sport & 12.009 & $R \$ 184.345$ \\
\hline Palmeiras X Internacional & 15.496 & $R \$ 259.100$ \\
\hline Palmeiras X Flamengo & 23.550 & $R \$ 391.400$ \\
\hline Palmeiras X São Paulo & 16.124 & $\mathrm{R} \$ 384.770$ \\
\hline Palmeiras X Goiás & 18.576 & $R \$ 201.430$ \\
\hline Palmeiras X Náutico & 8.980 & $\mathrm{R} \$ 199.085$ \\
\hline Palmeiras X Grêmio & 22.667 & $R \$ 428.170$ \\
\hline Palmeiras X Paraná Clube & 23.793 & $\mathrm{R} \$ 291.390$ \\
\hline Palmeiras X Juventude & 16.577 & $R \$ 287.555$ \\
\hline Palmeiras X Fluminense & 24.693 & $\mathrm{R} \$ 316.182$ \\
\hline Palmeiras X Atlético-MG & 23.534 & $\mathrm{R} \$ 444.265$ \\
\hline TOTAL & 315.401 & $\mathrm{R} \$ 4.930 .117$ \\
\hline Média & 17.522 & $R \$ 274.450$ \\
\hline
\end{tabular}

Fonte: https://futpaulista.webnode.com.br/palmeiras/campeonato-brasileiro-2007/ acesso em $31 / 01 / 2020$ 
Tabela 07 - Público e Renda - Campeonato Brasileiro: Palestra Italia 2008 em Mil R\$

\begin{tabular}{|c|c|c|}
\hline 2008 & $\begin{array}{c}\text { Público } \\
\text { Pagante(pessoas) }\end{array}$ & Renda \\
\hline Palmeiras X Internacional & 10.081 & $\mathrm{R} \$ 377.412$ \\
\hline Palmeiras X Atlético-PR & 6.264 & $\mathrm{R} \$ 171.495$ \\
\hline Palmeiras X Cruzeiro & 6.272 & $\mathrm{R} \$ 161.195$ \\
\hline Palmeiras X Náutico & 14.186 & $\mathrm{R} \$ 383.332$ \\
\hline Palmeiras X Figueirense & 19.012 & $R \$ 507.115$ \\
\hline Palmeiras X Fluminense & 13.568 & $\mathrm{R} \$ 366.937$ \\
\hline Palmeiras X Santos & 21.339 & $R \$ 571.567$ \\
\hline Palmeiras X Flamengo & 26.854 & $\mathrm{R} \$ 780.035$ \\
\hline Palmeiras X Vitória & 18.190 & $R \$ 523.250$ \\
\hline Palmeiras X Coritiba & 15.210 & $R \$ 413.395$ \\
\hline Palmeiras X Portuguesa & 8.180 & $\mathrm{R} \$ 252.975$ \\
\hline Palmeiras X Sport & 15.992 & $\mathrm{R} \$ 431.925$ \\
\hline Palmeiras X Vasco da Gama & 22.944 & $\mathrm{R} \$ 625.047$ \\
\hline Palmeiras X Atlético-MG & 25.319 & $\mathrm{R} \$ 713.905$ \\
\hline Palmeiras X São Paulo & 26.676 & $\mathrm{R} \$ 769.962$ \\
\hline Palmeiras X Goiás & 13.999 & $\mathrm{R} \$ 371.625$ \\
\hline Palmeiras X Grêmio & 25.945 & $R \$ 761.095$ \\
\hline Palmeiras X Ipatinga & 10.042 & $\mathrm{R} \$ 281.512$ \\
\hline Palmeiras X Botafogo-RJ & 21.639 & $R \$ 581.567$ \\
\hline TOTAL & 320.660 & $R \$ 9.057 .339$ \\
\hline Média & 16.877 & $R \$ 476.702$ \\
\hline
\end{tabular}

Fonte: https://futpaulista.webnode.com.br/palmeiras/campeonato-brasileiro-2008/ acesso em $31 / 01 / 2020$ 
Tabela 08 - Público e Renda - Campeonato Brasileiro: Palestra Italia 2009 em Mil R\$

\begin{tabular}{|c|c|c|}
\hline 2009 & $\begin{array}{c}\text { Público } \\
\text { Pagante(pessoas) }\end{array}$ & Renda \\
\hline Palmeiras X Coritiba & 19.105 & $\mathrm{R} \$ 391.941$ \\
\hline Palmeiras X São Paulo & 12.023 & $\mathrm{R} \$ 472.201$ \\
\hline Palmeiras X Vitória & 16.118 & $\mathrm{R} \$ 347.561$ \\
\hline Palmeiras X Cruzeiro & 11.214 & $R \$ 356.776$ \\
\hline Palmeiras X Santos & 8.277 & $\mathrm{R} \$ 257.931$ \\
\hline Palmeiras X Náutico & 7.800 & $\mathrm{R} \$ 267.356$ \\
\hline Palmeiras X Santo André & 19.041 & $\mathrm{R} \$ 590.128$ \\
\hline Palmeiras X Fluminense & 16.301 & $\mathrm{R} \$ 536.171$ \\
\hline Palmeiras X Grêmio & 25.440 & $\mathrm{R} \$ 862.666$ \\
\hline Palmeiras X Botafogo-RJ & 24.231 & $\mathrm{R} \$ 850.471$ \\
\hline Palmeiras X Internacional & 22.101 & $\mathrm{R} \$ 734.836$ \\
\hline Palmeiras X Barueri & 23.357 & $\mathrm{R} \$ 994.111$ \\
\hline Palmeiras X Atlético-PR & 23.395 & $\mathrm{R} \$ 1.008 .031$ \\
\hline Palmeiras X Avaí & 16.597 & $\mathrm{R} \$ 705.471$ \\
\hline Palmeiras X Flamengo & 26.462 & $\mathrm{R} \$ 1.246 .776$ \\
\hline Palmeiras X Goiás & 18.070 & $\mathrm{R} \$ 722.461$ \\
\hline Palmeiras X Sport & 17.133 & $\mathrm{R} \$ 714.886$ \\
\hline Palmeiras X Atlético-MG & 25.402 & $\mathrm{R} \$ 583.961$ \\
\hline TOTAL & 331.323 & $\mathrm{R} \$ 11.621 .616$ \\
\hline Média & 18.407 & $\mathrm{R} \$ 645.645$ \\
\hline
\end{tabular}

Fonte: https://futpaulista.webnode.com.br/palmeiras/campeonato-brasileiro-2009/ acesso em $31 / 01 / 2020$

Tabela 09 - Público e Renda - Campeonato Brasileiro: Palestra Italia 2010 em Mil R\$

\begin{tabular}{|l|c|c|}
\hline \multicolumn{1}{|c|}{$\mathbf{2 0 1 0}$} & $\begin{array}{c}\text { Público } \\
\text { Pagante(pessoas) }\end{array}$ & Renda \\
\hline Palmeiras X Vitória & 6.025 & $\mathrm{R} \$ 186.547$ \\
\hline Palmeiras X Grêmio & 18.365 & $\mathrm{R} \$ 538.961$ \\
\hline TOTAL & $\mathbf{2 4 . 3 9 0}$ & $\mathbf{R} \$ \mathbf{7 2 5 . 5 0 8}$ \\
\hline Média & $\mathbf{1 2 . 1 9 5}$ & $\mathbf{R} \$ \mathbf{3 6 2 . 7 5 4}$ \\
\hline
\end{tabular}

Fonte: https://futpaulista.webnode.com.br/palmeiras/campeonato-brasileiro-2010/ acesso em $31 / 01 / 2020$ 
No período de 2007 a 2009 a receita de bilheteria do clube como mandante no Campeonato Brasileiro registrou números de $R \$ 4.130 .117$ a $R \$ 11.621 .616$. O público oscila entre 6.000 e 23.000 pessoas. No ano de 2010 o Palmeiras jogou apenas duas partidas pelo Campeonato Brasileiro devido ao início das obras do novo estádio.

Tabela 10 - Público e Renda - Campeonato Brasileiro: Allianz Parque 2016 em Mil R\$

\begin{tabular}{|l|c|c|}
\hline \multicolumn{1}{|c|}{$\mathbf{2 0 1 6}$} & $\begin{array}{c}\text { Público } \\
\text { Pagante(pessoas) }\end{array}$ & Renda \\
\hline Palmeiras X Atlético PR & 33.629 & $\mathrm{R} \$ 2.078 .159$ \\
\hline Palmeiras X Fluminense RJ & 28.534 & $\mathrm{R} \$ 1.567 .292$ \\
\hline Palmeiras X Corinthians & 39.935 & $\mathrm{R} \$ 2.763 .659$ \\
\hline Palmeiras X Santa Cruz PE & 34.162 & $\mathrm{R} \$ 2.167 .071$ \\
\hline Palmeiras X América MG & 27.429 & $\mathrm{R} \$ 1.543 .521$ \\
\hline Palmeiras X Figueirense SC & 32.834 & $\mathrm{R} \$ 1.935 .545$ \\
\hline Palmeiras X Santos & 40.035 & $\mathrm{R} \$ 2.847 .299$ \\
\hline Palmeiras X Atlético MG & 39.400 & $\mathrm{R} \$ 2.935 .305$ \\
\hline Palmeiras X Vitória BA & 30.330 & $\mathrm{R} \$ 1.975 .055$ \\
\hline Palmeiras X Ponte Preta & 29.138 & $\mathrm{R} \$ 1.866 .690$ \\
\hline Palmeiras X São Paulo & 39.944 & $\mathrm{R} \$ 2.742 .013$ \\
\hline Palmeiras X Flamengo RJ & 32.885 & $\mathrm{R} \$ 2.289 .326$ \\
\hline Palmeiras X Coritiba PR & 30.962 & $\mathrm{R} \$ 2.202 .283$ \\
\hline Palmeiras X Sport PE & 31.107 & $\mathrm{R} \$ 2.172 .551$ \\
\hline Palmeiras X Internacional RS & 31.967 & $\mathrm{R} \$ 2.112 .466$ \\
\hline Palmeiras X Botafogo RJ & 39.690 & $\mathrm{R} \$ 3.174 .043$ \\
\hline Palmeiras X Chapecoense SC & 40.986 & $\mathrm{R} \$ 4.171 .317$ \\
\hline TOTAL & $\mathbf{5 8 2 . 9 6 7}$ & $\mathbf{R} \$ \mathbf{2 . 3 8 4 . 9 1 7}$ \\
\hline Média & $\mathbf{3 4 . 2 9 2}$ & \\
\hline
\end{tabular}

Fonte: http://app.globoesporte.globo.com/futebol/publico-no-brasil/2016 acesso em 09/01/2020 
Tabela 11 - Público e Renda - Campeonato Brasileiro: Allianz Parque 2017 em Mil R\$

\begin{tabular}{|l|c|c|}
\hline \multicolumn{1}{|c|}{$\mathbf{2 0 1 7}$} & $\begin{array}{c}\text { Público } \\
\text { Pagante(pessoas) }\end{array}$ & Renda \\
\hline Palmeiras X Vasco da Gama RJ & 33.425 & $\mathrm{R} \$ 2.109 .686$ \\
\hline Palmeiras X Atlético Mineiro & 34.240 & $\mathrm{R} \$ 2.118 .119$ \\
\hline Palmeiras X Fluminense RJ & 33.066 & $\mathrm{R} \$ 2.126 .139$ \\
\hline Palmeiras X Atlético PR & 29.778 & $\mathrm{R} \$ 1.706 .659$ \\
\hline Palmeiras X Atlético Goianiense & 29.014 & $\mathrm{R} \$ 1.590 .702$ \\
\hline Palmeiras X Flamengo RJ & 27.831 & $\mathrm{R} \$ 1.830 .939$ \\
\hline Palmeiras X Botafogo RJ & 23.562 & $\mathrm{R} \$ 1.230 .114$ \\
\hline Palmeiras X Corinthians & 39.091 & $\mathrm{R} \$ 2.744 .600$ \\
\hline Palmeiras X Cruzeiro MG & 37.961 & $\mathrm{R} \$ 2.832 .058$ \\
\hline Palmeiras X Santos & 37.527 & $\mathrm{R} \$ 2.712 .846 .716$ \\
\hline Palmeiras X Vitória BA & 36.263 & $\mathrm{R} \$ 2.139 .244$ \\
\hline Palmeiras X Avaí SC & 33.633 & $\mathrm{R} \$ 2.195 .369$ \\
\hline Palmeiras X São Paulo & 33.537 & $\mathrm{R} \$ 1.071 .430$ \\
\hline Palmeiras X Chapecoense SC & 21.261 & $\mathrm{R} \$ 935.034$ \\
\hline Palmeiras X Sport PE & 18.744 & $\mathbf{R} \$ \mathbf{3 0 . 1 0 3 . 6 5 5}$ \\
\hline TOTAL & $\mathbf{4 6 8 . 9 3 3}$ & $\mathbf{2 . 0 0 6 . 9 1 0}$ \\
\hline Média & $\mathbf{3 1 . 2 6 2}$ & \\
\hline Fonte: & & 2017 \\
\hline
\end{tabular}

Fonte: $\quad$ http://app.globoesporte.globo.com/futebol/publico-no-brasil/2017/ acesso em 09/01/2020 
Tabela 12 - Público e Renda - Campeonato Brasileiro: Allianz Parque 2018 em Mil R\$

\begin{tabular}{|l|c|c|}
\hline & $\begin{array}{c}\text { Público } \\
\text { Pagante(pessoas) }\end{array}$ & Renda \\
\hline Palmeiras X Vitória BA & 41.256 & $\mathrm{R} \$ 3.514 .618$ \\
\hline Palmeiras X América MG & 39.424 & $\mathrm{R} \$ 2.615 .582$ \\
\hline Palmeiras X Santos & 38.938 & $\mathrm{R} \$ 2.723 .127$ \\
\hline Palmeiras X Corinthians & 38.568 & $\mathrm{R} \$ 2.781 .213$ \\
\hline Palmeiras X Fluminense RJ & 37.430 & $\mathrm{R} \$ 2.480 .932$ \\
\hline Palmeiras X Flamengo RJ & 36.882 & $\mathrm{R} \$ 2.598 .847$ \\
\hline Palmeiras X Paraná Clube & 35.776 & $\mathrm{R} \$ 2.565 .986$ \\
\hline Palmeiras X Botafogo RJ & 24.882 & $\mathrm{R} \$ 1.446 .357$ \\
\hline Palmeiras X Atlético PR & 24.601 & $\mathrm{R} \$ 1.263 .083$ \\
\hline Palmeiras X São Paulo & 32.841 & $\mathrm{R} \$ 2.172 .299$ \\
\hline Palmeiras X Chapecoense SC & 30.671 & $\mathrm{R} \$ 1.749 .826$ \\
\hline Palmeiras X Vasco da Gama RJ & 30.012 & $\mathrm{R} \$ 1.907 .270$ \\
\hline Palmeiras X Atlético MG & 29.246 & $\mathrm{R} \$ 1.517 .906$ \\
\hline Palmeiras X Bahia BA & 26.351 & $\mathrm{R} \$ 1.507 .726$ \\
\hline Palmeiras X Sport PE & 25.947 & $\mathbf{R} \$ \mathbf{3 2 . 7 7 5 . 6 5 7}$ \\
\hline TOTAL & $\mathbf{4 9 2 . 8 2 5}$ & $\mathbf{2 . 1 8 5 . 0 4 3}$ \\
\hline Média & $\mathbf{3 2 . 8 5 5}$ & 2918 \\
\hline
\end{tabular}

Fonte: http://app.globoesporte.globo.com/futebol/publico-no-brasil/2018 acesso em 09/01/2020

Nos anos de 2016, 2017 e 2018 a receita de bilheteria do clube nas partidas em que atuou como mandante no Allianz Parque registrou valores entre $R \$$ 30.103.655 e $R \$ 40.543 .595$, com público pagante oscilando entre 20.000 e 40.000 pessoas.

1.3.2. Distribuição das Receitas

Os gráficos a seguir demostram as fontes de receitas do clube entre 2007 a 2010 no Palestra Italia. 
Gráfico 01 - Distribuição das receitas - SEP - Período Palestra Italia 2007

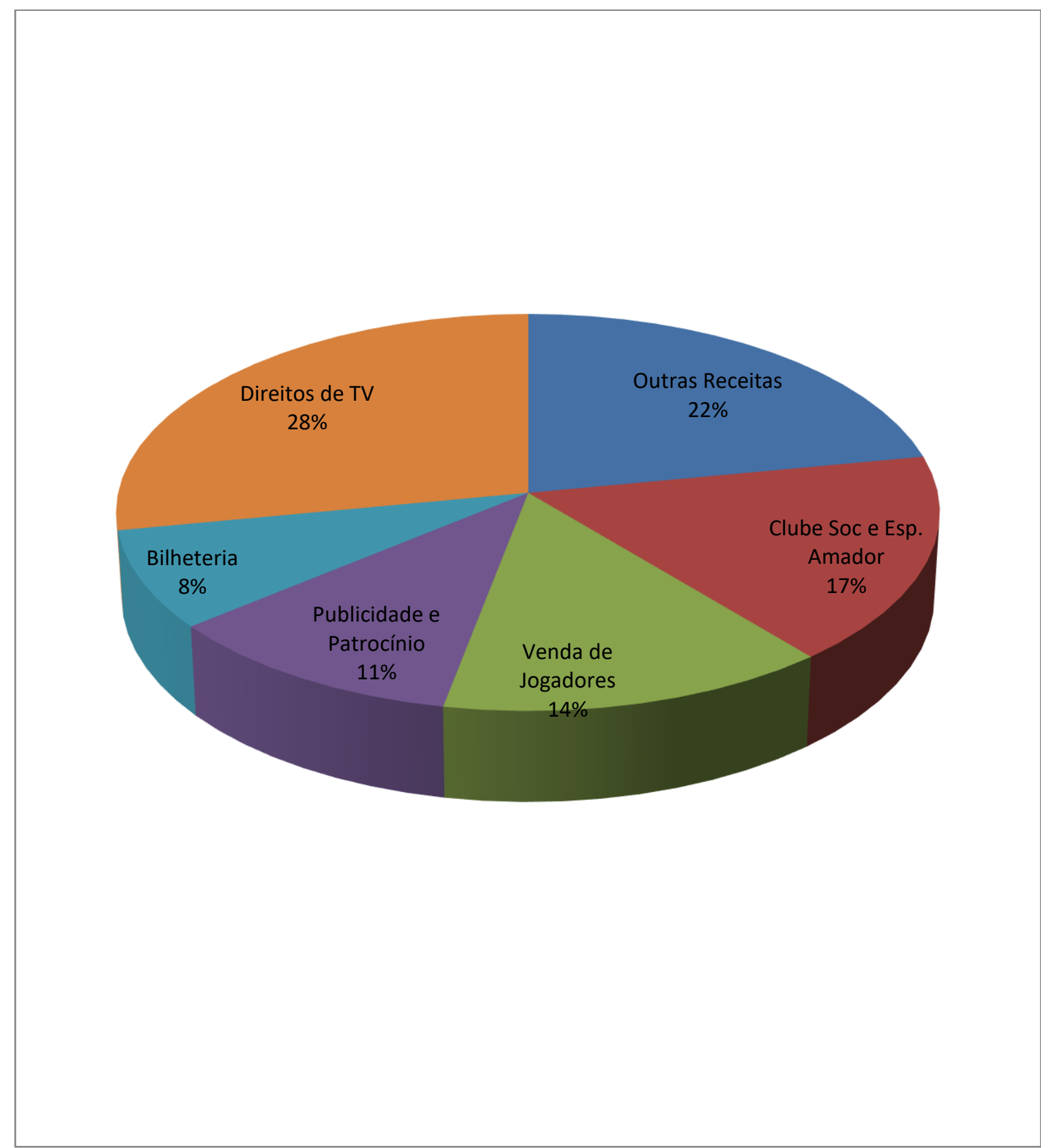

Fonte:Jornal Lance! - Blog Amir Somoggi-www.blogs.lance.com.br/somoggi - acesso em 10/03/2018. 
Gráfico 02 - Distribuição das receitas - SEP - Período Palestra Italia 2008

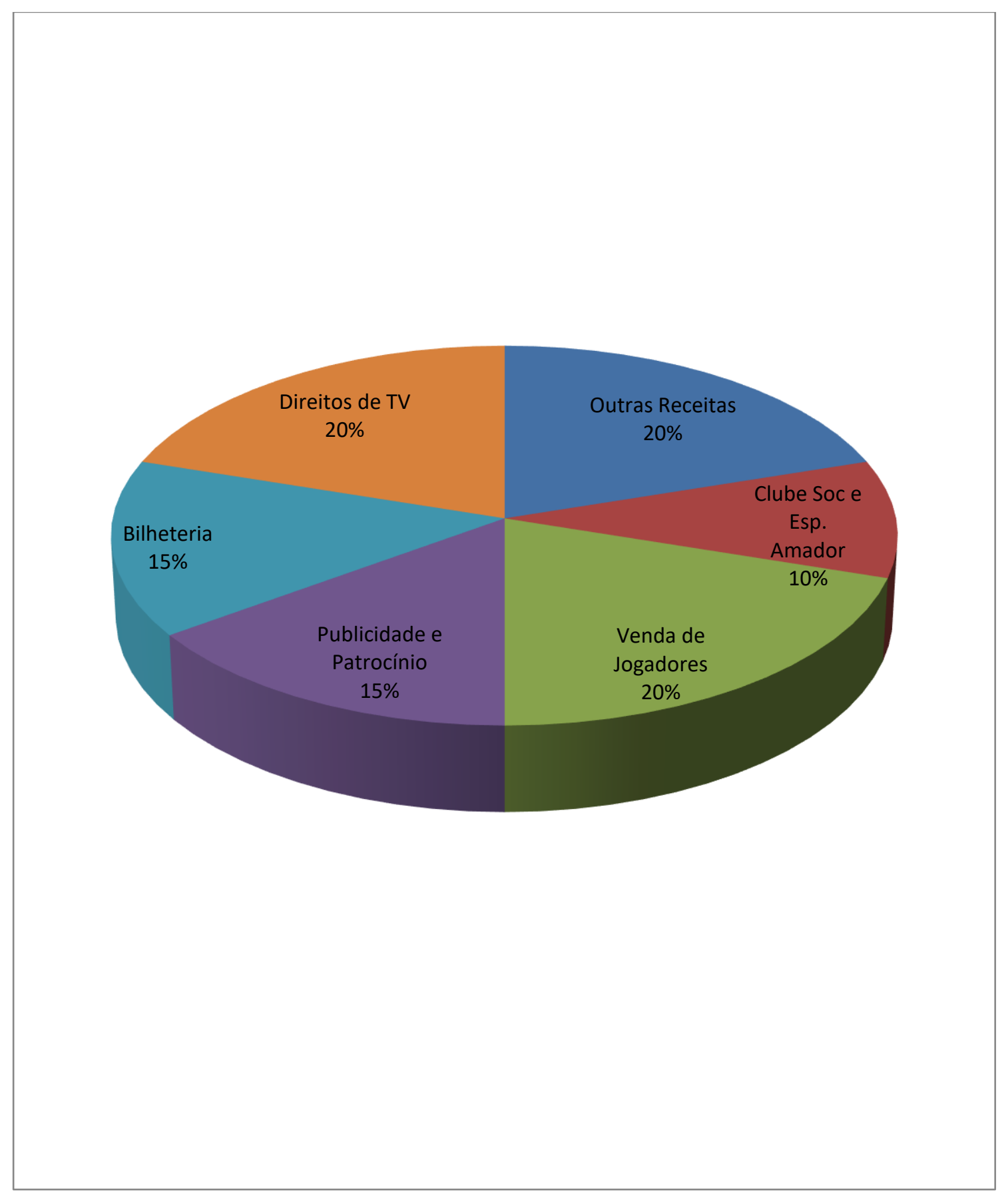

Fonte:Jornal Lance! - Blog Amir Somoggi-www.blogs.lance.com.br/somoggi - acesso em 10/03/2018. 
Gráfico 03 - Distribuição das receitas - SEP - Período Palestra Italia 2009

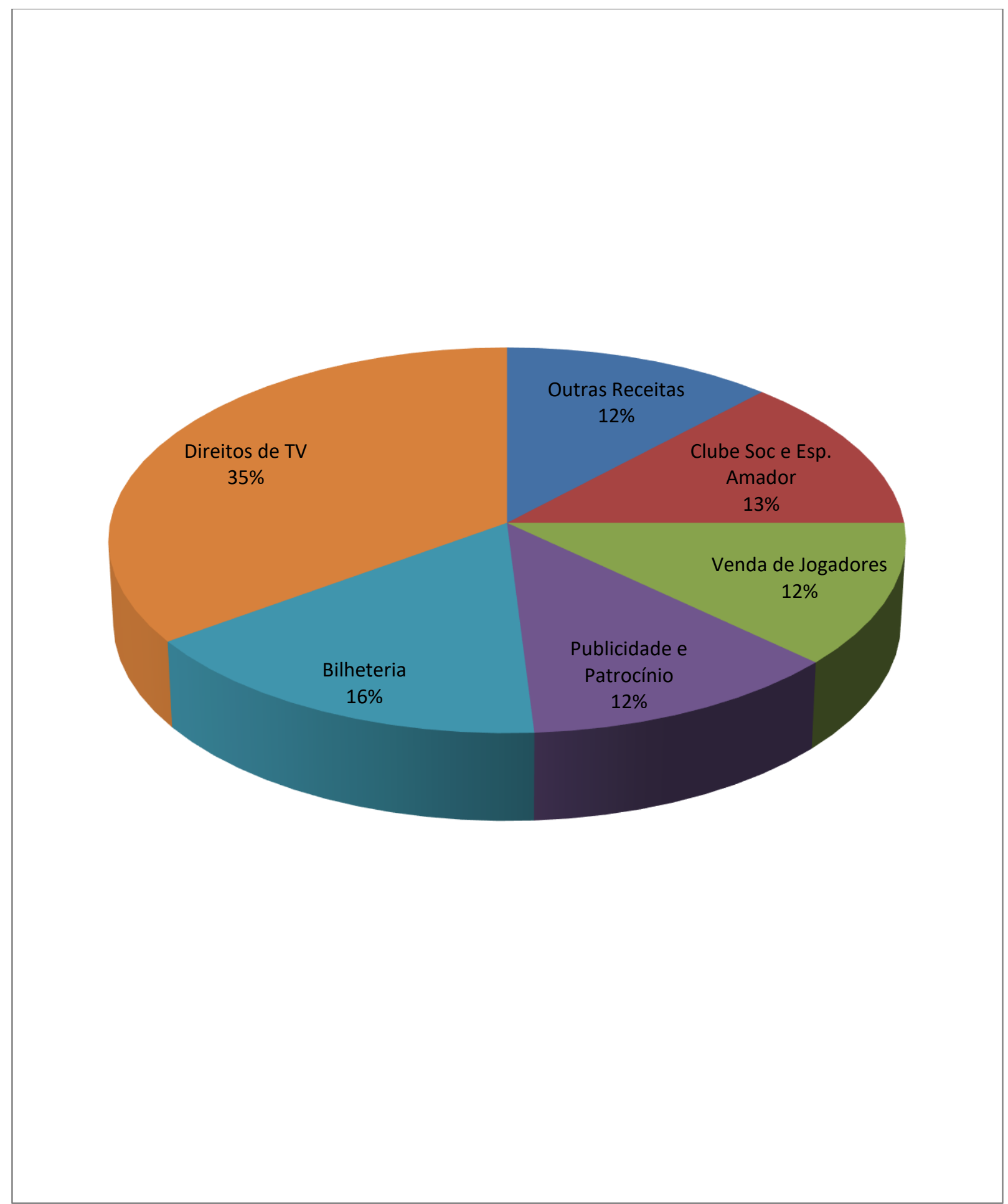

Fonte:Jornal Lance! - Blog Amir Somoggi-www.blogs.lance.com.br/somoggi - acesso em 10/03/2018. 
Gráfico 04 - Distribuição das receitas - SEP - Período Palestra Italia 2010

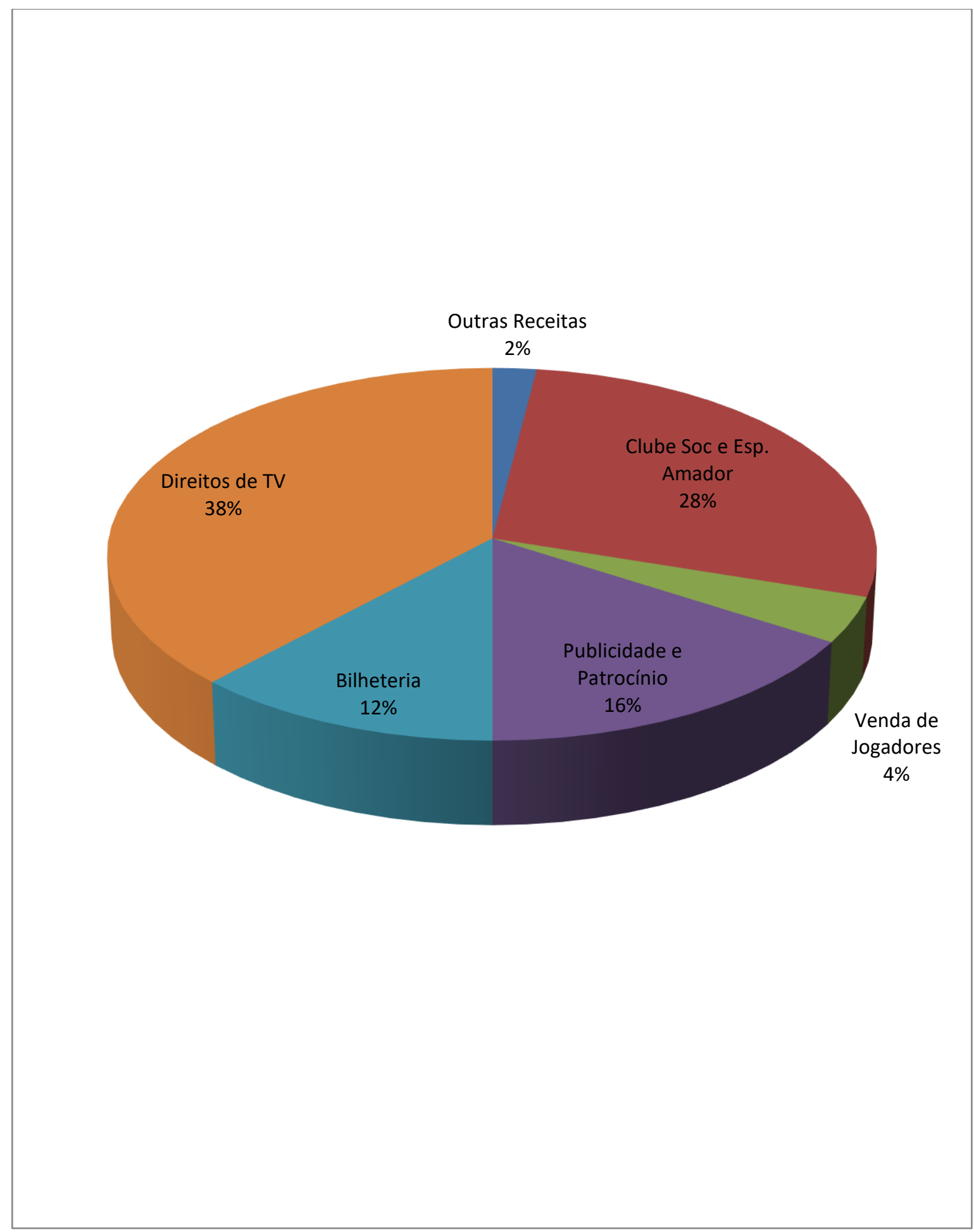

Fonte:Jornal Lance! - Blog Amir Somoggi-www.blogs.lance.com.br/somoggi - acesso em 10/03/2018. 
Da análise dos demonstrativos acima retratados, nota-se, como já mencionado, que as receitas entre 2007 a 2010, registraram a seguinte variação: "Direitos de TV" - subiram de 28\% em 2007 para 38\% em 2010; "Bilheteria", passou de $8 \%$ em 2007 para 16\% em 2009, ano do lançamento do programa sóciotorcedor da Sociedade Esportiva Palmeiras. Em 2010, quando da demolição do Palestra Italia para construção do Allianz Parque, houve queda na receita do clube com bilheteria pelos poucos jogos efetuados, atingindo 12\%. Contudo, como se verificará no capítulo alusivo à construção do novo estádio, após sua inauguração houve um considerável aumento das receitas consideradas não-esportivas do clube, relativas a shows e eventos diversos. Essas receitas representam um grande ganho novo para o clube.

A demolição do Palestra Italia, já na sua forma de Jardim Suspenso, foi episódio dramático, como já nos referimos anteriormente, com conselheiro se atirando em frente as máquinas para evitar o início dos trabalhos, e a ousadia, que foi decisiva, do conselheiro José Cirillo, responsável pela Comissão de Obras, que atropelou o processo de liberação formal diante da insegurança e indecisão da direção da Sociedade Esportiva Palmeiras e autorizou a abertura das atividades. $\mathrm{O}$ ato traz o símbolo de inserir o Palmeiras na Economia do Futebol, até então ignorada pelo clube.

Um clube de tradição conservadora e que administrava suas contas por intermédio de processos arcaicos e personalistas, tem, através de ato considerado corajoso por parte de um velho engenheiro da Escola Politécnica, o canal que the permite o exórdio na nova economia que já se instalara há muito tempo. A demolição acabou sendo, de modo icônico, uma literal destruição criativa schumpeteriana.

Para entendermos o significado econômico da transmutação do Palestra Italia em Allianz Parque é preciso compreender o papel do surgimento e consolidação da nova economia que adentrou a campo, a Economia do Futebol. 


\title{
CAPÍTULO II - A ECONOMIA DO FUTEBOL
}

O aumento significativo dos valores pecuniários injetados na indústria do futebol, por intermédio de patrocinadores; direitos de transmissão, que cresceram em larga escala com a revolução tecnológica e a globalização; novos interessados envolvidos (novos "stakeholders"), com a descoberta de mercados "nunca dantes navegados", como a Ásia; a relação entre equipamentos esportivos utilizados pelos atletas e o consumo por parte da população cativa; esse conjunto todo, e imenso em aporte financeiro, consagrou o que chamamos de Economia do Futebol. Ela está lastreada na indústria do entretenimento que passou a dominar nosso futebol.Uma economia própria, com participação relevante no PIB dos países e do mundo, com capacidade para provocar impactos econômicos, políticos e sociais, com potência para ser notada e considerada. Dados divulgados pela consultoria DELOITTE apontam que o mercado do futebol movimentou em 2018, apenas na Europa, valores estimados em $R \$ 112$ bilhões. No Brasil foram movimentados $R \$$ 52,9 bilhões, segundo estudo realizado a pedido da Confederação Brasileira de Futebol $^{33}$. Não podem ser menosprezados, são cifras que impõem um impacto a provocar uma nova realidade no futebol.

No início do século XX, quando tais cifras ainda eram modestas, LEONCINI (2001) observou:

\begin{abstract}
"A indústria do entretenimento, como setor cada vez mais importante da economia de serviços, apresenta crescimento contínuo, e o esporte como negócio toma cada vez mais espaço dentro deste setor. Senão, basta olharmos seus números representativos da percentagem do PIB em alguns países. De acordo com estudos realizados em 1997 pelo ministério do Esporte e Turismo, cerca de 1 milhão de empregos podem ser criados em dez anos no Brasil devido ao desenvolvimento da indústria, do comércio e do setor de serviços com a profissionalização do esporte. Isto se torna ainda mais importante para o Brasil, o país do futebol, onde o esporte
\end{abstract}

33 Dados do relatório apresentado pela empresa de consultoria EY, contratada pela Confederação Brasileira de Futebol (https://www.mktesportivo.com/2019/12/ey-e-cbfapresentam-relatorio-sobre-impacto-do-futebol-na-economia/) 
representa apenas $0,1 \%$ do $\mathrm{PIB}$. Se compararmos este número aos números do esporte em outros países(e aos do futebol na Itália) podemos visualizar melhor o que o esporte, e particularmente 0 futebol brasileiro pode representar em termos sócio-econômicos".

O potencial de crescimento na participação do PIB era claro e havia um caminho a ser explorado, com atraso, é verdade. Em 2018, segundo estudo feito pela EY a pedido da CBF, o futebol movimentou 52,9 bilhões de reais, cerca de $0,7 \%$ do PIB. Embora tenha multiplicado por sete a participação, no Produto Interno Bruto, ainda há um longo potencial a ser realizado.

O estudo da riqueza na economia do futebol e sua relação com os movimentos da economia mundial e, sobreudo, da brasileira, demanda o estabelecimento de um paralelo entre o desenvolvimento econômico do país e o do futebol, a fim de traçar o quadro histórico entre essas questões e a descoberta da matriz econômica investigada. A correlação existente, em termos acadêmicos, se constui em tarefa mais complexa pela carência de dados disponíveis, deve ser estudada com mais profundidade em outro trabalho,porém a indução provocada pode ser claramente observada.

O futebol como se conhece hoje nasce no final do século XIX na Inglaterra. Há vários registros anteriores de jogos semelhantes ${ }^{34}$, mas é possível ter como marco do futebol contemporâneo o ano de 1863, quando são realizadas as primeiras partidas entre escolas e universidades. Reconhecida como esporte coletivo surgido no período vitoriano, essa prática desportiva colocava-se como forma de rebeldia contra a rigidez daqueles tempos e manifestação afirmativa da busca pelo entretenimento, a arrostar a rigorosa e estafante jornada nas fábricas inglesas. Uma referência às hegemonias econômica e cultural britânica, o futebol

\footnotetext{
${ }^{34}$ PRONI, 2000, p.19: "Formas de jogos em que se chuta uma bola foram registradas em diferentes povos da Antiguidade (no Japão, na China, na Grécia, em Roma), em civilizações nativas das Américas, assim como durante a Idade Média em diferentes localidades da Europa. Com o Renascimento, no século XVI, surgiu em Florença, na Itália, uma competição denominada calcio, realizada anualmente no dia de São João, que muitos consideram a primeira versão do futebol moderno. Mas o futebol do qual falamos - essa atividade recreativa racionalmente organizada, desvinculada do calendário de festas cívicas ou religiosas, com manual de regras e árbitro para inibir a violência ou a trapaça, e com campeonatos regidos por uma associação esportiva que representa os interesses dos times - surgiu somente em meados do século XIX na Inglaterra."
} 
que surgiu na Inglaterra, à época a economia dominante, vivia a consolidação de um século de Revolução Industrial.

No Brasil ele chega logo a seguir, e os primeiros clubes são oficializados em 1900: Sport Clube Rio Grande e Associação Atlética Ponte Preta. Ganha impulso a partir de 1910 e só no final desse ano se consolidam competições regionais sistematizadas.

$\mathrm{Na}$ passagem para o século $\mathrm{XX}$, ao contrário de países como Inglaterra, França e Estados Unidos, o Brasil ainda engatinhava num processo de industrialização tardia, preso às amarras de um passado colonial. Sua condição periférica dependente econômica e tecnologicamente das grandes potências capitalistas limitava suas atividades industriais, que se resumiam basicamente à produção de tecidos e alimentos. O processo de urbanização era incipiente, pois grande parte da população vivia no campo e a economia movimentava-se de acordo com os altos e baixos da cafeicultura. Já a Argentina vivia seu auge na economia, o que coincide com sua supremacia no futebol, indicando uma relação estrita entre desempenho futebolístico e potencial econômico.

Contudo, desde a introdução do futebol no Brasil em 1895 por Charles Muller ${ }^{35}$, clubes sociais tradicionais e outros formados por imigrantes que adquiriam estabilidade no trabalho e buscavam maior socialização, foram tomando conta do processo que, organizacionalmente, estabeleceu-se de modo amador na maioria dos casos.

Esse amadorismo prevaleceu por muitos anos, e o regime de trabalho profissional dos atletas só se impôs entre 1934 e 1937, durante duro embate entre CBD e FBF. Esse profissionalismo dos jogadores não se estendeu à gestão dos

${ }^{35}$ ARAUJO, 2000, p.51: "O futebol também fazia parte do cenário; foi introduzido por Charles Miller, um brasileiro descendente de ingleses que, ao retornar de uma temporada de estudos na Inglaterra, trouxera em sua bagagem uma bola e os uniformes para duas equipes. Miller havia se tornado um praticante do futebol durante sua estada na GrãBretanha. (...) Quando voltou ao Brasil, Miller encontrou a prática esportiva começando a ser difundida, principalmente dentro da pequena colônia inglesa, formada por funcionários das empresas britânicas situadas em São Paulo. Querendo fazer o mesmo pelo football association, Miller arregimentou alguns funcionários da Companhia de Gás, do London Bank e da São Paulo Railway (companhia que construiu e explorava o transporte ferroviário entre Jundiaí e o porto de Santos) e realizou o primeiro jogo de futebol em terras brasileiras, mais especificamente na Várzea do Carmo." 
clubes, que permaneceu amadora, quando muito semiprofissional, com alguns fatores agregados aos hábitos de administração, porém ainda muito calcada em protagonismos pessoais, mecenato e arrecadações externas ao meio do futebol, como bailes de carnaval de clubes.

Entre 1937 e 1950 acentuou-se a popularização do futebol, o profissionalismo consolidado em 1937, embora incipiente, conteve a saída de jogadores brasileiros rumo ao exterior e vinculou com mais força os ídolos ao torcedor, aumentando a relação apaixonada entre torcedor e clube. Nesse perído, conforme WTTER, (Apud LEONCINI ${ }^{36}$, surge a prática de compra do passe do jogador que irá mantê-lo preso ao arbítrio dos donos e dirigentes dos clubes.

Em 1950 o futebol dá um primeiro salto, tímido, anêmico, todavia direcionado para uma organização mais estruturada no âmbito da seleção nacional, depois do fracasso retumbante na Copa do Mundo no Maracanã. Mas não houve progresso sustentável e caminhamos desestruturados para 1958, onde houve, aí sim, um apelo decisivo na direção de um planejamento profissional e abrangente, bastante inspirado no Plano de Metas de Juscelino Kubitschek ${ }^{37}$, sobretudo no espírito do tempo que emergia, o de um novo país que poderia ser construído, a instilar entusiasmo e crença na capacidade de superação dos nossos desafios. E o futebol, como uma paixão e patrimônio nacional, até então menoscabado, constituise em objetivo nacional liderado por Paulo Machado de Carvalho, que pelas conquistas alcançadas recebeu o epíteto de "Marechal da Vitória".

Porém, se a gestão chegou à Seleção Brasileira, isso não ocorreu com a administração dos clubes, que permaneceu atada aos liames do antagonismo formal, com força arcaica, a obnubilar a visão de progresso e a obstar o desenvolvimento gerencial.

A cúpula dos clubes de futebol era formada por pessoas da elite das respectivas cidades, com raras exceções mesmo em agremiações populares. $\mathrm{O}$

\footnotetext{
${ }^{36}$ WTTER, J.S. 1996 (Apud LEONCINI). O que é o futebol. SP, Ed. Brasiliense.

37 O Plano de Metas continha objetivos determinados pelo ex-presidente Juscelino Kubitschek (1956-1961), apresentado na campanha eleitoral, que consistia no investimento em áreas prioritárias para o desenvolvimento econômico, principalmente infraestrutura (rodovias, hidrelétricas, aeroportos) e indústria.
} 
futebol era uma das formas de afirmação dessas pessoas na sociedade, e em geral resvalava para o mecenato, modelo comum que foi exemplificado por Romeu Ítalo Rípoli no XV de Piracicaba. ${ }^{38}$ Os dirigentes que controlavam os clubes comportavam-se, e até hoje muitos se comportam, da mesma forma, como grande parte do empresariado nacional, inspirados no patrimonialismo, na busca por facilidades governamentais e em gestão personalizada, predominantemente autoritária, a ignorar a administração com base técnica e racional.

Enquanto o país viveu a glória dos três campeonatos mundiais, com seleções que tiveram planejamento e organização, com boa base gerencial, os clubes se permitiam ignorar tal opção. Nesse aspecto, da indução vinda de acontecimentos de fora do mundo do futebol, destacam-se o Consenso de Washington ${ }^{39}$ como indutor do clube-empresa na Inglaterra, por intermédio do Manchester United ${ }^{40}$, que é referência mundial para esse movimento de mercado, e o Plano de Metas de Juscelino Kubitschek, como galvanizador da organização do planejamento para a Copa de 1958, o "milagre econômico", sob égide militar a tanger o planejamento da Copa de 1970.

\subsection{Gênese}

Houve dois momentos cruciais para a implantação da Economia do Futebol: a constituição da Nike, que em 1972 assinou o primeiro contrato com jogador de basquete profissional, desencadeando a nova riqueza que emergia no valor agregado do patrocínio de grandes atletas - em 1982 a empresa patrocinava 120 jogadores; e 1978, com Bill Rasmussen ${ }^{41}$, que transmitia jogos universitários em Connecticut voltado para o mercado local, alugando satélite para transmissões via

\footnotetext{
${ }^{38}$ Romeu Ítalo Ripoli, nascido em Piracicaba, foi um engenheiro agrônomo, empresário, político e Presidente do Esporte Clube XV de Novembro de Piracicaba entre 1959 a 1964 e 1974 a 1983.

39 O Consenso de Washington reúne um conjunto de medidas econômicas que foram apresentadas em 1989 no International Institute for Economy, na capital dos Estados Unidos.

${ }^{40}$ Manchester United Football Club é um clube inglês de futebol sediado em Trafford, na região metropolitana de Manchester (Reino Unido).

${ }^{41}$ William F. Rasmussen, conhecido como "Bill Rasmussen", foi um dos fundadores da ESPN - Entertainment Sports Programming Network.
} 
TV a cabo. Ele introduziu jogos colegiais de atletismo e futebol americano, ganhou uma licitação para TV a cabo e montou a ESPN, Entertainment Sports Programming Network. $\mathrm{O}$ canal passou a transmitir 24 horas por dia e juntou-se à rede $A B C$, o que levou a investimentos em novos ginásios, e a TV passou a transmitir não apenas esporte, mas a indução de compra de material esportivo que desfilava durante todo o tempo na programação. $O$ assessor de imprensa desempregado que iniciou o processo, vendeu parte de suas ações por U\$ 10 milhões a um investidor de Wall Street, uma semana depois de ter ganho a licitação (o mercado enxergou o tamanho do negócio), e quando foi adquirida pela $A B C$, a parte do modesto fundador já valia U\$ 30 milhões. O torcedor-espectador se transformara em objeto de consumo.

NBA, Nike e ESPN perceberam que milhões de pessoas, todos os dias, acompanhando atletas de ponta, constitulam-se em outro valor de negócio. A Copa do Mundo de 1970, com a transmissão ao vivo e em cores, suscitara uma nova era, que foi se espraiando por todos os esportes, sobretudo, o futebol.

O primeiro movimento em direção à valorização dos estádios começou, como aludimos anteriormente, com a reforma e construção de ginásios nas transmissões regionais da ESPN nos EUA. Custou muito tempo para que o Brasil entendesse a importância de uma arena esportiva na relação com o torcedor-cliente. Até hoje, o estádio da Associação Portuguesa de Desportos é exemplo dessa incompreensão, permanecendo por anos como passivo acarretando despesas de manutenção e depreciação. Agora que se pensa em sua utilização para recuperação financeira.

Entre 1950 e 1980, o Brasil cresceu em média 7,5\% ao ano, e entre 1980 e 2017 a média foi de apenas 2,5\%. Mensurado com base nos preços do indicador "paridade de poder de compra", em 1980 o PIB per capita do Brasil se encontrava pouco acima de 40\% dos EUA, declinando para perto de 25\% em 2017. Em 1990 fomos superados pela Coréia do Sul, que atualmente se aproxima da renda per capita do Reino Unido; em 2005 fomos superados pela Turquia e em 2016 pela China.

Nos anos efusivos - de 1950 a 1980 - o maior indutor do crescimento brasileiro foi a política industrial, que se iniciou no governo Getílio Vargas com as 
indústrias de base e se consolidou com Juscelino Kubitschek, com a indústria de bens de capital, período retratado na obra Metrópole e Cultura ${ }^{42}$ :

\begin{abstract}
"Na vivência de muitos de seus contemporâneos, o Brasil, nos meados do século XX, ensaiava trilhar um alvissareiro caminho histórico, anunciador do efetivo rompimento com as peias que o atavam ao passado; passado este que se recusava a morrer. É como se a débâcle do Estado Novo, a instauração das instituições democráticas e a emergência de um surto desenvolvimentista sem paralelos descortinassem a possibilidade de 'forjar nos trópicos este suporte de civilização moderna'. O período inaugurado no pós-guerra suscitava forte sentimento de otimismo, nascido da mescla entre triunfos materiais de vulto e permanências das nossas singularidades. Diferentemente da Europa, forçada a reter as lembranças da dizimação humana, a guardar a memória da barbárie totalitária e a conviver com o incômodo reconhecimento da perda da sua hegemonia civilizacional, o país parecia, finalmente, assenhorear-se dos segredos criadores da modernidade, que, diga-se de passagem, identificava-se genericamente como estilo de vida norte-americana." (ARRUDA, 2015, p.23)
\end{abstract}

E prossegue a autora:

\begin{abstract}
"Modernização, modernismo e modernidade foram termos que por vezes se confundiam e, em repetidas ocasiões, se distinguiam. De modo geral, modernização referia-se ao aceleramento das mudanças urbano-industriais, à diversificação dos padrões de consumo, à alteração nas formas de comportamento que passaram a se guiar por princípios semelhantes aos vigentes nos países desenvolvidos. Modernismo carreava significados próprios à produção da cultura, uma polifonia de sentidos múltiplos, abrangendo tanto as correntes tributárias de 1922 quanto aquelas aclimatadas no período." (ARRUDA, 2015,p.24)
\end{abstract}

Além da política industrial de Juscelino, corroborou para o atingimento dos resultados a questão demográfica, quando a população aumentava acima de 2,5\% ao ano, e a população em idade ativa crescia ainda mais, colaborando com o crescimento do PIB na sua totalidade. Neste contexto, questiona-se: teria o perfil

${ }^{42}$ ARRUDA, Maria Arminda do Nascimento. Metrópole e Cultura. Editora Edusc, 2001. 
da curva de crescimento do PIB da riqueza do país, influenciado no desempenho do futebol?

Entre 1958 e 1970, quando nos encontrávamos no período em que fomos o país com maior crescimento no mundo, disputamos quatro campeonatos mundiais e vencemos três. Foi o momento em que nos consagramos diante do mundo como o "país do futebol", e, segundo Nelson Rodrigues, começamos a nos libertar do complexo de vira-latas, despontando para reconhecimento de nossa excelência em atividade onde fomos considerados os "melhores do mundo". Uma referência de qualidade, o chamado "benchmarking do futebol", de acordo com as maiores potências rivais, seja na imprensa respectiva, seja no âmbito dos profissionais do esporte. Entre 1980 e 1994, quando vagamos pela década perdida e hiperinflação, passamos 24 anos sem ganhar o campeonato mundial. Durante o período glorioso, nossos melhores jogadores, nossos craques, quase todos permaneciam no Brasil, e as transferências para a Europa eram raras exceções.

A partir de 1980 se acelerou o processo denominado "exportação de pé de obra", transformando-se em êxodo substantivo. Em 1970, nenhum atleta da seleção jogava em times do exterior, já em 1994 dos vinte e dois atletas convocados, onze jogavam em times do exterior. 
Tabela 13 - Seleção Brasileira da Copa de 1970

\begin{tabular}{|c|c|c|}
\hline Jogador & Posição & Clube \\
\hline Félix & Goleiro & (2) Fluminense FC \\
\hline Ado & Goleiro & (2) SC Corinthians \\
\hline Leão & Goleiro & $\ominus$ SE Palmeiras \\
\hline Carlos Alberto & Defesa & $\theta$ Santos FC \\
\hline Zé Maria & Defesa & (2) A Portuguesa D \\
\hline Marco Antônio & Defesa & Fluminense FC \\
\hline Everaldo & Defesa & ○ Grêmio FBPA \\
\hline Brito & Defesa & $\theta$ CR Flamengo \\
\hline Piazza & Defesa & ○ Cruzeiro EC \\
\hline Baldocchi & Defesa & $\theta$ SE Palmeiras \\
\hline Fontana & Defesa & Cruzeiro EC \\
\hline Joel & Defesa & $\theta$ Santos FC \\
\hline Clodoaldo & Meia & Santos FC \\
\hline Gérson & Meia & $\theta$ São Paulo FC \\
\hline Rivellino & Meia & ○ sc Corinthians \\
\hline Paulo Cézar & Meia & Botafogo FR \\
\hline Jairzinho & Atacante & $\theta$ Botafogo FR \\
\hline Tostão & Atacante & (2) Cruzeiro EC \\
\hline Pelé & Atacante & $\theta$ Santos FC \\
\hline Roberto & Atacante & $\theta$ Botafogo FR \\
\hline Edu & Atacante & $\theta$ Santos FC \\
\hline Dario & Atacante & (2) Atlético Mineiro \\
\hline
\end{tabular}

Fonte: Programação TV FIFA www.fifa.com - Acesso em 15/04/2018 
Tabela 14 - Seleção Brasileira da Copa de 1994

\begin{tabular}{|c|c|c|}
\hline Jogador & Posição & Clube \\
\hline Taffarel & Goleiro & Reggiana \\
\hline Jorginho & Lateral Direito & Bayern Munique \\
\hline Ricardo Rocha & Zagueiro & $\ominus$ Vasco da Gama \\
\hline Ronaldão & Zagueiro & - Shimizu S-Pulse \\
\hline Mauro Silva & Volante & La Coruña \\
\hline Branco & Lateral Esquerdo & $\ominus$ Fluminense \\
\hline Bebeto & Atacante & La Coruña \\
\hline Dunga & Volante & VfB Stuttgart \\
\hline Zinho & Meia & Palmeiras \\
\hline Raí & Meia & PSG \\
\hline Romário & Atacante & Barcelona \\
\hline Zetti & Goleiro & ○ São Paulo \\
\hline Aldair & Zagueiro & Roma \\
\hline Cafu & Lateral Direito & ○ São Paulo \\
\hline Márcio Santos & Zagueiro & Bordeaux \\
\hline Leonardo & Lateral Esquerdo & ○ São Paulo \\
\hline Mazinho & Lateral Esquerdo & Palmeiras \\
\hline Paulo Sérgio & Meia & Bayer Leverkusen \\
\hline Muller & Atacante & ○ São Paulo \\
\hline Ronaldo & Atacante & $\theta$ Cruzeiro \\
\hline Viola & Atacante & Corinthians \\
\hline Gilmar & Goleiro & Flamengo \\
\hline
\end{tabular}

Fonte: Programação TV FIFA www.fifa.com - Acesso em 15/04/2018

É claro que a variação de riqueza de um país, que serve como indicador da respectiva macroeconomia, influi na situação econômica das empresas e dos indivíduos. A macroeconomia penetra na microeconomia. Isso usualmente é desprezado tantos nas análises como na formulação de planos no futebol, gerando consequências que poderiam ser evitadas. Como planejar sem levar em conta o ambiente econômico que contempla o projeto? Pois no futebol, apesar dos 
montantes envolvidos, embora tenha se constituído economia própria, ocorre tamanho paradoxo.

Por coincidência ou não, em 1994, com a introdução do Plano Real, que se iniciou com o estabelecimento da URV - Unidade Real de Valor (parte escritural da atual moeda corrente do Brasil), como forma de equilibrar e dar harmonia às correções de preços, o Brasil "saiu da fila", da longa escuridão de quase duas décadas e meia, para retornar ao panteão da glória futebolística na Copa dos EUA. Mas já vínhamos de um crescimento importante em 1993, com PIB acima de 4\% após um número negativo em 1992. Em 1999 a taxa de crescimento foi em torno de zero e 2000 registrou uma inflexão positiva que levou o PIB a patamar superior a $4 \%$, mantendo-se positivo até 2002, quando ganhamos o quinto campeonato mundial.

Mas seriam esses dados suficientes para procedermos a relação de causaefeito? Certamente não. Cabe estudo mais aprofundado, todavia sabemos que a economia de um país em estágio de crescimento acaba por influenciar um longo espectro de atividades, entre elas a área de entretenimento, que possui um comportamento elástico com relação ao aumento da renda per capita. Porém, nosso desejo é avançar um tanto mais, e verificar com mais precisão como a variação do PIB e suas respectivas consequências impactam o futebol. A tarefa é ousada porque há poucos estudos a respeito desse ponto, mostrando que, de fato, no Brasil, como disse Hilário Franco Jr., "o futebol é muito jogado e pouco estudado".

No livro Por que as Nações Fracassam ${ }^{43}$, Daron Acemoglu sustenta que as nações fracassam ou triunfam economicamente, não por conta da injeção de recursos, sejam externos ou internos, e sim por constituírem instituições extrativistas, que remetem ao insucesso; ou triunfam por serem inclusivas, o que as conduzem ao sucesso. Instituições inclusivas seriam aquelas que suscitam círculo virtuoso, que surge não só da lógica do pluralismo democrático e do estado de direito, mas também por produzirem instituições economicamente inclusivas - o que traz uma distribuição de renda mais igualitária, conferindo mais poder e

\footnotetext{
${ }^{43}$ ACEMOGLU, Daron; ROBINSON, James. Op.cit. Rio de Janeiro, Elsevier, 2012.
} 
autonomia a segmento mais amplo da sociedade, dando mais equilíbrio à participação dos estratos sociais no jogo político. Tais instituições enraízam nas sociedades comportamentos e procedimentos que as tornam mais prósperas e menos iníquas, com maior distribuição e aproveitamento da riqueza adquirida.

As extrativistas tendem à concentração de renda, retirando da sociedade grande parte dos ganhos obtidos pelo país, tornando a nação menos igualitária, absorvendo a seiva da riqueza de modo pouco distributivo. As instituições no Brasil, e especificamente no futebol, teriam sido inclusivas ou extrativistas?

Vamos procurar observar, além da relação PIB e receita de clubes, bem como da questão de indicadores macro e microeconômicos, o que ocorria no Brasil nos períodos citados, no sentido mais amplo do funcionamento das instituições políticas, econômicas e sociais, para ganharmos maior aprofundamento na análise.

A realidade é que o Brasil cresceu exponencialmente entre 1950 e 1970, sobretudo entre 1956 e 1970, período em que vencemos três de quatro campeonatos mundiais disputados entre seleções. Não foi um crescimento homogêneo, destacando-se o período de 1956 a 1961. Em 1962, quando houve um declínio e perdurava a crise política originada pela renúncia de Jânio Quadros e as dificuldades de consolidação do governo Jango Goulart, voltando ao crescimento significativo, acima de 5\%, em 1966, que se estendeu até 1973, quando ocorreu a crise mundial do petróleo.

O que se passava em nossa economia nesse período?

No artigo "Ciclos e mudanças estruturais na economia brasileira do pósguerra"44, publicado pela UNICAMP - Universidade Estadual de Campinas na série Economia 30 Anos, sob o título geral "Desenvolvimento Capitalista no Brasil", José Serra escreve:

"Foi a partir de meados dos anos 50 até o início dos anos 60 que a industrialização brasileira sofreu transformações estruturais decisivas. Esse avanço foi realizado sob o impulso do Plano de Metas do governo Kubitschek (56-60) e caracterizou-se por uma intensa diferenciação

44 SERRA, J. Ciclos e Mudanças Estruturais na Economia Brasileira do Após Guerra. Revista Economia Política, 1982. 
industrial num espaço de tempo relativamente curto e articulada diretamente pelo Estado. Nesse período instalaram-se no país as indústrias automobilística, de construção naval, material elétrico pesado e outras máquinas e equipamentos, permitindo uma significativa ampliação dos bens de capital. Ao mesmo tempo, expandiram-se consideravelmente indústrias básicas como a siderúrgica, a de metais não-ferrosos, química pesada, petróleo, papel e celulose". (SERRA, 1982)

\title{
O Brasil crescia indiscutivelmente, mas como se dava esse crescimento?
}

Conforme João Manuel Cardoso de Mello e Fernando Novais, em "Capitalismo Tardio e Sociabilidade Moderna"45:

\begin{abstract}
"Os trinta anos que vão de 1950 a 1980 - anos de transformações assombrosas, que pela rapidez e profundidade, dificilmente encontrarão paralelo neste século - não poderiam deixar de aparecer aos seus protagonistas senão sob uma forma: a de uma sociedade em movimento. Movimento de homens e mulheres que se deslocam de uma região a outra do território nacional, de trem, pelas novas estradas de rodagem, de ônibus ou amontoados em caminhões paus de arara. São nordestinos e mineiros, fugindo da miséria e da seca, em busca de destino melhor em São Paulo, no Rio de Janeiro, no Paraná da terra roxa...

Movimento de uma configuração de vida para outra: da sociedade rural abafada pelo tradicionalismo para o duro mundo da concorrência da grande cidade, ou para o mundo sem lei da fronteira agrícola; da pacata cidadezinha do interior para a vida já um tanto agitada da cidade média ou verdadeiramente alucinada da metrópole". (MELLO; NOVAIS, 2009)
\end{abstract}

\section{Os autores comparam o perfil do brasileiro de 1950 com 1980:}

"Matutos, caipiras, jecas: certamente era com esses olhos que, em 1950, os 10 milhões de citadinos viam os outros 41 milhões de brasileiros que moravam no campo, nos vilarejos e cidadezinhas com menos de 20 mil habitantes. Olhos de gente moderna, "superior", que enxerga gente atrasada, "inferior"." (MELLO; NOVAIS, 2009)

"Em 1980, as cidades abrigavam 61 milhões de pessoas, contra os quase 60 milhões que moravam no campo, em vilarejos e cidades pequenas. Nada menos do que 42 milhões viviam em cidades com mais de 250 mil habitantes". (MELLO; NOVAIS, 2009)

São Paulo só ultrapassa o Rio de Janeiro em número de habitantes no censo de 1960. O ano de 1950 é o do desastre futebolístico do Maracanã, apelidado de "Maracanazo", com a retumbante derrota da seleção diante do Uruguai, trazendo à

${ }^{45}$ MELLO, J.M. de e NOVAIS, F.A. Capitalismo tardio e sociabilidade moderna. São Paulo: Unesp, 2009. 
tona o complexo de vira-latas cunhado por Nelson Rodrigues, e a "Legião 16 de Junho", dos denominados derrotistas, pelo jornalista Thomaz Mazzoni ${ }^{46}$. Em 1970, o Brasil era tricampeão mundial, ascendia admirado mundialmente pelos craques que possuía e ostentava o galardão internacional de "O País do Futebol".

Como foi essa transformação? É importante entender a dinâmica mundial.

Luiz Gonzaga de Mello Belluzzo, em prefácio à obra de Celso Furtado "Formação Econômica do Brasil"47 - comenta essa relação entre o crescimento do Brasil e a influência externa, que é a base do livro de Furtado:

"Começo com uma reflexão de outro mestre, o professor Fernando Novais. Diz ele, em seu livro de ensaios Aproximações, que "embora seja um lugar comum afirmar que o Brasil é fruto da colonização européia, nem sempre se levam na devida conta todas as implicações envolvidas nessa assertiva."48 (BELLUZZO, 2005).

E continua:

\begin{abstract}
"Assim, por exemplo, o sucesso do Brasil, até o início dos anos 80, desencadeou a crise que iria provocar o seu reiterado "fracasso" na tentativa de se ajustar às novas condições internacionais. No pólo oposto, o fracasso chinês até os anos 80 propiciou condições iniciais mais favoráveis para o sucesso das reformas empreendidas a partir de então". (BELLUZZO, 2005).
\end{abstract}

Tomando como referência as observações de Belluzzo acima citadas, a influência europeia no futebol se deu da seguinte forma: em seu exórdio ao final do século XIX até 1950, houve uma assimilação da nomenclatura, com a utilização constante de termos como "goalkeeper"49, "center-forward"50, "center-back"51,

46 Thomaz Mazzoni foi um dos grandes jornalistas que fizeram parte da equipe do jornal A Gazeta Esportiva. Autor de apelidos e alcunhas para times de futebol e partidas clássicas, faleceu no dia 14 de janeiro de 1970 na cidade de São Paulo.

${ }^{47}$ FURTADO, Celso. Formação econômica do Brasil. São Paulo: Companhia das Letras, 2007.

${ }^{48}$ NOVAIS, Fernando. Aproximações, Estudos de história e Historiografia. Casacnaify, São Paulo, 2005.

49 Tradução: Goleiro.

50 Tradução: Centroavante.

51 Tradução: Centro de volta 
"toss"52 em vez de sorteio, "half time"53, mas na prática do jogo em campo, na dinâmica, nem na organização do seu funcionamento, ocorreu "colonização futebolística". Os ingleses e demais europeus cuidavam de seus campeonatos, o sistema era bem endógeno em cada país e havia pouca preocupação em estender à América do Sul a forma de jogar. Por outro lado, no Brasil ninguém possuía a menor preocupação em copiar ou introduzir no país sistemas de administração de clubes e órgãos de organização como os da Europa. Diferentemente da economia e da política, o futebol não se espelhava nem dependia dos modelos de países europeus, embora houvesse certa reverência dos dirigentes brasileiros a tratarem os europeus como um mundo superior. Da parte dos europeus, eles mantinham o controle do órgão máximo de administração, a FIFA, constituída em 1904 por sete países do continente: Bélgica, Dinamarca, Espanha, Suiça, Suécia, França e Holanda. Observe-se que o país considerado o "inventor do futebol moderno", a Inglaterra, estava tão fechada em si mesma que não fez parte do grupo pioneiro, tal era a independência de cada país com relação aos seus campeonatos e eventos. Por 70 anos a FIFA foi presidida por europeus, e teve o primeiro não-europeu e sulamericano a assumir o comando em 1974, com João Havelange ${ }^{54}$, brasileiro filho do belga Faustin Havelange e que se chamava Jean-Marie Faustin Goedefroid Havelange. Havelange reinou no futebol mundial até 1988, produzindo o maior salto econômico no órgão, com um crescimento brutal do faturamento, utilizando-se de técnicas mercantilistas, muito marketing e imensa utilização da venda dos diretos econômicos de transmissão por TV, além da façanha de reunir na FIFA mais países afiliados do que a Organização das Nações Unidas - ONU. Certamente a sua origem e o domínio do inglês e francês foram decisivos para sua aceitação pelos europeus.

52 Tradução: Sorteio

53 Tradução: Meia hora

54 Jean-Marie Faustin Goedefroid Havelange, mais conhecido como João Havelange, foi um advogado, empresário, atleta e dirigente esportivo brasileiro. Eleito para a FIFA em 1974, permaneceu à frente da entidade até 1998. Organizou seis Copas do Mundo. 
Tabela 15 - Países filiados à FIFA e à ONU

\begin{tabular}{|l|c|}
\hline Organização das Nações Unidas - ONU & 193 \\
\hline $\begin{array}{l}\text { Federação Internacional de Futebol } \\
\text { Associação - FIFA }\end{array}$ & 211 \\
\hline
\end{tabular}

Fonte: Revista Abril www.https://exame.abril.com.br - acesso em 14/04/2018

Porém, até 1950 a Europa pouco se preocupava com o futebol fora do seu respectivo continente, portanto não exercia qualquer ação organizada para impor suas práticas e costumes ao Brasil. A Copa de 1950 foi rechaçada por vários países europeus que não tiveram o menor interesse em participar, pois a Copa do Mundo não tinha importância significativa.

Tabela 16 - Países europeus que participaram da Copa de 1950

\begin{tabular}{|l|l|l|l|l|}
\hline * Suécia & MT Espanha & + Inglaterra & II Itália & 4 Suíça \\
\hline
\end{tabular}

Fonte: https://esportes.terra.com.br- acesso em 14/04/2018

Em 1954, com o título da Alemanha, que teve o significado de uma ressurreição do país após a II Grande Guerra, iniciou-se uma relação de interpretação também política sobre os campeonatos mundiais. A vitória na Suíça, quando a Alemanha suplantou inesperadamente a favorita Hungria de Ferenc Puskas ${ }^{55}$, foi chamada de "Milagre de Berna".

55 Ferenc Puskás Biró foi um futebolista e treinador húngaro. É considerado o maior futebolista da história do futebol húngaro e um dos maiores futebolistas de todos os tempos. Defendeu também a Seleção Espanhola. 
Figura 6 - 0 Milagre de Berna (Das Wunder von Bern) ${ }^{56}$

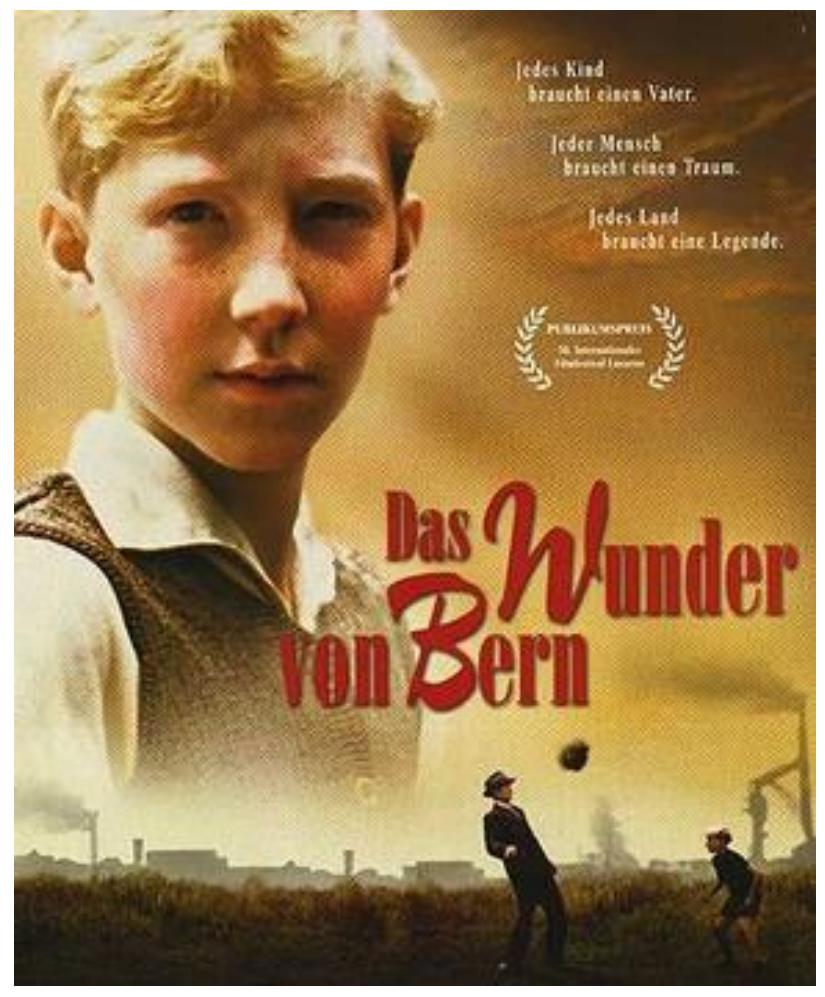

Fonte: Livraria Folha - https://livraria.folha.com.br - acesso em 14/04/2018

Deu-se um primeiro sinal de internacionalização política do sentido de ganhar uma Copa do Mundo, compartilhado por todo o mundo do futebol, em integração consentida. Mussolini usou o bicampeonato de 1934-1938 da Itália para gáudio político, mas com repercussão apenas interna. Em 1954, deu-se o desatar dos laços que envolviam o futebol mundial em caixas segregadas por países, com relação ao vislumbrar do sentido mais amplo de uma Copa do Mundo. Além da vitória futebolística em si, agregou-se o sentido de potência ao país vencedor, estendido às questões econômicas, políticas e sociais.

E foi exatamente em 1954, após uma Copa em que o Brasil foi eliminado pela Hungria, seleção sensação da Copa, favorita em todos os prognósticos, por $4 \times 2$, num jogo bastante disputado, mas que a eliminação brasileira produziu um comportamento reportado como escandaloso, quando o técnico brasileiro atirou

${ }^{56}$ Das Wunder von Bern: O Milagre de Berna é um filme alemão dirigido por Sönie Wortmann, lançado em 2003. 
a chuteira no rosto de desafetos no vestiário, surgiu a primeira ideia de necessidade de organização em nosso futebol.

Em a "Dança dos Deuses"- Futebol, Sociedade e Cultura, Hilário Franco Júnior $^{57}$ resumiu a participação brasileira e suas consequências na Copa da Suíca de 1954:

\begin{abstract}
"Dois meses antes da morte de Vargas, teve ínicio o quinto Mundial de futebol, sediado na Suiça. A instabilidade do Brasil refletiu - se na desorganização e falta de preparo da seleção. O técnico, Zezé Moreira, afirmava que não era necessário conhecer o times adversários, e o chefe da delegação, João Lyra Filho, sustentava que o importante era fazer os jogadores beijarem a bandeira nacional no vestiário. Na terceira partida, o time assemelhava - se ao governo brasileiro, perdido em campo, fustigado à direita e á esquerda pela favorita seleção da Hungria, organizada num 42-4 inovador (item 6.3). Além da derrota por 4 a 2, os brasileiros envolveram-se na maior briga registrada em uma Copa do Mundo, denominada a Batalha de Berna, que envolveu jogadores, dirigentes, jornalistas e policiais, no campo e nos vestiários A violência era uma espécie de resposta às acusações de que faltara coragem na final de 1950, e mais uma vez procuraram-se os responsáveis pela derrota brasileira. Um artigo de $O$ Estado de $S$. Paulo mencionava "causas talvez raciais, talvez morais, talvez sentimentais, que possam ter influído para tal estado de coisas" (6/7/1954). O complexo de inferioridade mantinha-se ainda forte na auto - imagem dos brasileiros e de sua seleção."(FRANCO Jr., 2007, p.92, 93)
\end{abstract}

A Copa de 1954 não só introduziu o futebol no campo da política, no mundo, com a narrativa do feito alemão, como se constituiu no grande marco para a primeira iniciativa verdadeiramente organizada e planejada para se estruturar 0 futebol, a princípio, via seleção. Era o início do Plano Paulo Machado de Carvalho ${ }^{58}$, que chefiou a delegação brasileira na conquista do bicampeonato mundial 58-62, na Suécia e no Chile. Concomitante a tal fato, a economia brasileira iniciava sua maior ascensão na história, que foi catalisada por Juscelino Kubitschek a partir de 1956 com o Plano de Metas.

\footnotetext{
${ }^{57}$ FRANCO Jr., Hilário. A Dança dos Deuses - Futebol, Sociedade, Cultura. Editora Schwarcz Ltda. 2007.

58 Paulo Machado de Carvalho foi um advogado e empresário, conhecido com o título de "Marechal da Vitória" por chefiar a delegação brasileira em duas Copas do Mundo. É considerado o maior responsável "fora de campo" pelas conquistas das Copas de 1958 e 1962.
} 
A ideia do Plano de Metas de Juscelino, o sentido de se ter um projeto que organizasse o futuro do país em busca de grandes objetivos, criou ambiente para outras iniciativas desse tipo, em várias áreas, mostrando que uma mobilização nacional provoca não só os resultados colhidos dos projetos diretos políticos e econômicos, mas também, suscitam ambiente e clima indutores de mobilizações no mesmo sentido, em outras atividades relevantes. Sem dúvida, o futebol brasileiro se beneficiou disso e Paulo Machado de Carvalho, empresário e dirigente de futebol no São Paulo F.C., acreditou ser possível colocar em prática a idéia seminal que ocorreu por conta do desastre brasileiro em 1954. O insucesso do Brasil, contudo, evidenciou uma desorganização bem maior do que fora avistada pela crítica, retirando do futebol praticado em campo a única culpa pelo insucesso, exigindo dos dirigentes alguma providência redentora.

Embora necessitemos de estudos mais aprofundados para estabelecer a relação de causa-efeito na correlação economia do país e progresso no futebol, é possível afirmar que as condições ambientais acima aludidas contribuíram largamente para o processo de gestão que levou o Brasil à conquista do bicampeonato. Em 1958, desde um plano detalhado de treinamento, cuidou-se de forma inédita da alimentação, do preparo físico dos jogadores. O lendário Paulo Amaral ${ }^{59}$, que exigia muito mais dos atletas acostumados a treinos físicos tíbios e até irrisórios, com pouca aplicação de conhecimentos científicos já disseminados em outros países da Europa, até a inovação da contratação de um psicólogo especialmente dedicado aos jogadores, que passou a conviver com eles, e que também se tornou lendário. João Carvalhaes, por sua inusitada importância, foi citado em quase todas as análises e crônicas que os especialistas da época fizeram sobre a exegese do sucesso que colocou o Brasil no mapa do mundo do futebol e o ascendeu no mundo político.

Carvalhaes foi um símbolo tão marcante quanto inesperado dessa conquista de 1958, que sua importância foi pesquisada e explicitada no artigo "João 
Carvalhaes, um psicólogo do futebol"60, de João Augusto de Evangelho Hernandez ${ }^{61}$, do Instituto de Psicologia da UERJ, em 2011, tanto tempo depois.

No livro já citado “ A Dança dos Deuses”, Hilário (2007) detalha o planejamento mencionado:

\begin{abstract}
"Machado de Carvalho procurou organizar um corpo técnico de especialistas para superar as rivalidades Rio - São Paulo, tanto que dos 22 jogadores que foram à Suécia, exatamente metade atuava num estado, metade em outro. O grupo de trabalho estratégico era composto pelos experientes jornallistas Ary Silva e Flávio lazetti (este versado e arbitragem), pelo réporter Paulo Planet Buarque, pelo psicológico João Carvalhaes e pelo técnico Vicente Feola, todos de São Paulo. O grupo de trabalho executivo era formado plo supervisor Carlos Nascimento, pelo observador Ernesto Santos, pelo preparador físico Paulo Amaral, pelo médico Hilton Gosling, pelo dentista Mário Trigo e pelo massagista Mário Américo, todos do Rio de Janeiro (embora desde 1953 este último tivesse trocado o Vasco pela Portuguesa). Elaborou-se detalhado plano de 96 artigos que partia da identificação dos erros cometidos nas competições internacionais anteriores. Buscou-se estabelecer um padrão de jogo preocupadoo com o equilbrio entre a eficiência defensiva e a ousadia ofensiva; definir um responsável pelo estudo das táticas e deficiências dos adversários; instituir um conjunto de normas disciplinares para os atletas; programar com bastante antecedência as viagens e hospedagens da delegação; inlcuir nela novidades para época: um dentista, um psicólogo e um fisioterapeuta (profisão recente no país, onde a primeira instituição do ramo havia sido criada em 1957); planejar até mesmo a compra de uniformes e de chuteiras adequadas a cada tipo de gramado. Ao presidente Bossa Nova, como JK ficou conhecido pelos traços modernos que imprimiu na política nacional, corresponde no futebol o doutor Paulo, como era chamado Machado de Carvalho pela gestão empresarial que implantou naquele esporte."(FRANCO Jr., 2007, p. 133, 134).
\end{abstract}

O Brasil passava por um período histórico, não só de transformação econômica com o registro do maior crescimento de PIB no mundo, no período, como também por transformações sociais profundas, não só do trânsito de país rural para urbano, não só de migração interna considerável, como também de configurações da vida social.

João Manuel Cardoso de Mello e Novais, em "Capitalismo Tardio e Sociabilidade Moderna", registram que as qualidades intelectuais, as de formação profissional, as de "caráter", as de trato pessoal, todas elas são geradas e desenvolvidas com base em configurações da vida social.

${ }^{60}$ CARVALHAES, J. Um psicólogo no futebol: relatos e pesquisas. São Paulo: Editora Esporte e Educação, 1974.

61 HERNANDEZ, J. A. E. João Carvalhaes, um psicólogo campeão do mundo de futebol. Estudos e Pesquisa em Psicologia, v. 11, 2011. 
O futebol não poderia passar ao largo do que estava ocorrendo no país e não se isentou do clima em curso. Como afirmou Edmund Burke: "As circunstâncias (que para alguns cavalheiros nada significam!), na realidade, conferem a cada princípio político a sua cor peculiar e o seu efeito especial".

Não é possível ignorar a circunstância, e o futebol, em seus estudos e pesquisas, quase sempre a ignorou, provocando uma lacuna expressiva na interpretação devida aos fatores relevantes para os resultados.

O período de pós-guerra foi aquele em que o mundo experimentou seu maior crescimento econômico com distribuição de renda, sobretudo na Europa. Tony Judt, em "Pós -Guerra - Uma história da Europa desde 1945"62 destaca:

\begin{abstract}
"Em retrospecto, o período de 1945 a 1989 (queda do Muro de Berlim) passaria a ser visto não como o limiar de uma nova era, mas como um interstício: seria como parêntese abertos no período pós-guerra, compreendendo questões mal resolvidas de um conflito terminado em 1945 mas cujo epílogo perdurara por mais de meio século". (JUDT, 2005).
\end{abstract}

Um espaço de tempo tão profundo, tão rico em mudanças fundamentais, não pode ser desprezado quando se avalia um processo social tão significativo como o futebol no Brasil.

Da introdução do futebol no Brasil, no século XIX, até 1950, os valores europeus, incluindo a modernidade inglesa e francesa, não se imiscuíram na dinâmica da nossa organização e prática, e predominou o conhecido antagonismo formal onde o futebol, embora tenha absorvido determinados valores modernos, foi também contemplado por ações de caráter retrógrado. O futebol sofreu muito mais influência das tensões internas de toda ordem, destacando-se a Semana de Arte Moderna de 1922 e a revolução de 1930.

PRONI (2000) destaca:

"Os valores da modernidade europeia não se manifestavam em sua plenitude no Brasil, porque as raízes da nossa sociedade não eram as mesmas e porque a nossa sociabilidade tinha sido muito marcada pelo estigma da escravidão e da exclusão social. Ou seja, ainda que em algumas atividades lúdicas estivessem inscritos certos valores e ideais

62 JUDT, J. Pós - Guerra - Uma história da Europa desde 1945. Lisboa: Edições 70, 2005 . 
considerados "modernos", estes entravam em choque com os costumes e ideias "retrógrados" que permeavam a maioria das práticas sociais e a própria intimidade do cotidiano das pessoas. E essa tensão permaneceu na época da transição para o profissionalismo...

Assim, não é de estranhar que as relações de trabalho no futebol profissional refletissem essa tensão". (PRONI, 2000).

A Segunda Grande Guerra levou o mundo para uma política auspiciosa de crescimento e distribuição de renda na Europa, patrocinada pelo Plano Marshall, e à hegemonia econômica americana com significativa exportação por parte dos Estado Unidos da América de seu "way of life", incluindo a cultura esportiva. Os valores liberais ganharam espaço no Brasil, sobretudo junto à nossa elite.

Uma área onde isso não ocorreu foi o futebol, que resistiu ao assédio dos valores americanos, até por ser esporte não identificado com os EUA. Mas a matriz europeia de valores passou a participar de forma mais marcante. A modernização do futebol no Brasil, que ganha corpo nos anos 70, tem forte influência da Europa, e é a interpretação política e a ressonância da vitória alemã na Suíça em 1954, que acentua o processo de juntar o sucesso nos gramados à relevância política dos países no contexto mundial.

Trazido à tona pelo horror disseminado na Europa pela guerra, a busca pelo entretenimento catapultou a vinculação afetiva entre as pessoas, transformadas em torcedores ainda mais apaixonados, e o futebol, que funcionou como válvula de escape. O futebol vai além de ser utilizado como orgulho nacional e assume papel de atividade fundamental para preencher as horas de lazer, sobretudo dos homens, tornando-se essencial na vida da sociedade. Rapidamente, por essa relevância e pelo aspecto econômico que passa a ter, a questão organizacional se impõe. Cuidar dos campeonatos nacionais passa a combinar a necessidade de agradar os torcedores com o aspecto econômico-financeiro envolvido.

Assim como o capitalismo tardou em nosso país, tal impulso chegou atrasado, sucedendo-se em escala relevante no Brasil apenas nos anos 70 . O futebol foi então contemplado pelo clima de crescimento mundial e, em especial, pelo crescimento econômico brasileiro, com destaque para o que trouxeram os anos $\mathrm{JK}$ e o otimismo e entusiasmo que permearam o país. 
O impacto financeiro trazido pelo momento bastante favorável das economias mundial e nacional entre 1954 e 1970, e o surto de progresso econômico não foi acompanhado por medidas significativas de modernização na administração do futebol. A "fumaça da boa gestão" só alcançou o Brasil a partir de 1970, quando o interesse da televisão ganhou corpo com a transmissão da Copa do Mundo do México, abrangendo vários países no mundo e acendendo a faísca na dimensão colossal de audiência que o esporte poderia ter.

Como os EUA, que guiavam a introdução de novos costumes no mundo, praticavam esportes sem apelo mundial, como beisebol, futebol americano e basquetebol, esse ganho de escala em audiência não foi produzido pelos americanos.

A Copa do México foi um divisor de águas e uma nascente do potencial de relevância econômica que a televisão poderia ter, induzindo a modernização na gestão desse "novo" ramo de entretenimento. O futebol, que possuía a capacidade de atrair assistentes no mundo todo, diferentemente dos esportes tradicionais americanos, e com potencial para contemplar bilhões de expectadores, passou a ser visto como fonte de geração de riqueza. Este potencial fica exemplificado já em 2002, conforme dados da tabela abaixo.

Tabela 17 - Assistência pela TV: Copas do Mundo

\begin{tabular}{|c|l|c|}
\hline 2002 & :* Coreia do Sul/ • Japão & 1.5 bilhão \\
\hline 2006 & Alemanha & 2.63 bilhões \\
\hline 2010 & África do Sul & 3.2 bilhões \\
\hline 2014 & Brasil & 3.2 bilhões \\
\hline 2018 & Rússia & 3.57 bilhões \\
\hline
\end{tabular}

Fonte: A Copa na televisão brasileira: 2002, 2006, 2010 Folha de São Paulo https://www1 folha.uol.com.br - acesso em 18/05/2019. https://esportes.estadao.com.br/noticias/ acesso em 17/05/2019 
A gestão dos clubes de futebol no Brasil até 1930 foi praticamente amadora, e a economia brasileira, que sofria a derrocada dos preços do café, não ajudou em nada, nem financeiramente, nem na indução de métodos de gestão.

De 1930 a 1950, enquanto o amadorismo se movia paulatinamente para um semiprofissionalismo bastante incipiente, o Brasil de Getúlio Vargas procurou reagir aos efeitos da Grande Depressão de $1929^{63}$ com políticas de defesa da economia nacional, construindo uma visão de nação, uma unidade que não existira até então. É possível afirmar que as medidas de Getúlio e a desorganização do mercado mundial em 1929 suscitaram um impulso significativo à industrialização do país, gerando um clima de otimismo.

A II Grande Mundial tornou mais abrangente o crescimento da indústria de bens de consumo de não-duráveis (têxteis, calçados, alimentos e bebidas) e de insumos como óleo e graxas vegetais, além de ferro gusa, tendo se iniciado a instalação da indústria pesada com a construção da siderúrgica de Volta Redonda ${ }^{64}$. A velha economia primário-exportadora começava a ser superada em que pese a as deficiências de infraestrutura deixadas, as desigualdades regionais e a nefasta distribuição de renda.

No plano político, o país enfrentava as turbulências trazidas pelo suicídio de Getúlio. Todavia, a posse de Juscelino e a implantação do Plano de Metas instalaram ambiente de otimismo e entusiasmo que influenciou consideravelmente a recuperação do orgulho nacional com o futebol, a convicção de que era preciso planejar e organizar, resultando no sucesso alcançado. Embora bafejados pelo crescimento econômico e pelo apelo ao desenvolvimento, alguns clubes com resultados financeiros originados pelo desenvolvimento, no caminho oposto ao que seria natural de modernização das respectivas administrações para o aumento de receitas e a conuista de independência econômica, os clubes se mantiveram em

${ }^{63}$ A Grande Depressão persistiu ao longo da década de 1930, terminando apenas com a Segunda Guerra Mundial.

64 Companhia Siderúrgica Nacional (CSN) é a maior indústria siderúrgica do Brasil e da América Latina. Sua usina situa-se na cidade de Volta Redonda. A CSN foi criada durante o Estado Novo por decreto do presidente Getúlio Vargas. 
sistema de administração arcaico e personalizado, patrimonialista, com forte centralização de poder, vício que até hoje nos debatemos, em outro estágio.

Contudo, os clubes ganham capacidade financeira, não pelos seus próprios méritos, mas pelo impulso dado pela ascensão do país, e conseguem manter no Brasil a grande maioria dos melhores atletas. Os doze anos decorridos entre 1958 e 1970 são, até hoje, o período mais auspicioso do futebol brasileiro no cenário mundial. Todavia desperdiçados no sentido da indenpedência que é o cerne desse trabalho.

Assim como o futebol perdeu potência a partir de 1974, que coincide com o choque do petróleo, o Brasil tem desaceleração desde então chegando à década perdida dos anos 80, que se estende até 1993. O período 1974-1994 foi o de maior crise no futebol brasileiro, não só ocorrido pelos erros de gestão e estruturação, mas também engolfado pela crise econômica. No perído de sucesso econômico, perdemos a oportunidade de consolidar os clubes brasileiros financeiramente e Ihes dar um porvir sustentável e estável. Na crise ntre 1974-1994, acumulamos as desditas, retardando e até involuindo na autonomia dos clubes e na qualificação perante o resto do mundo.

Em a "Metamorfose do futebol", PRONI (2000) destaca:

\begin{abstract}
"Até 1980, pelo menos, os problemas do futebol brasileiro ainda eram apresentados em termos de carência de organização e planejamento, e a solução era buscada em fórmulas mais eficazes para aumentar as receitas, o que não exigia necessariamente uma mudança radical no aparato jurídico-institucional do futebol. Entretanto, a grave recessão econômica de 1981/83 e o descontrole da inflação afetaram profundamente a rentabilidade da atividade futebolística, agravando os problemas e dando início ao que pode ser considerado como a crise mais séria do futebol brasileiro, desde a consolidação do profissionalismo". (PRONI, 2000).
\end{abstract}

Em 1989, o "Consenso de Washington"65 açambarcou o pensamento econômico mundial. Foi formulado em novembro por economistas de instituições

${ }^{65}$ O Consenso de Washington foi uma recomendação internacional elaborada em 1989, que visava a propalar a conduta econômica neoliberal com a intenção de combater as crises e misérias dos países subdesenvolvidos, sobretudo os da América Latina. Sua elaboração ficou a cargo do economista norte-americano John Williamson. 
financeiras como FMI, Banco Mundial, e o Departamento de Tesouro americano. Eram 10 medidas arroladas:
a) disciplina fiscal;
b) redução dos gastos públicos;
c) reforma tributária, com redução de impostos;
d) juros de mercado;
e) câmbio de mercado,
f) desregulamentação (lassidão das leis bancárias e trabalhistas);
g) investimento estrangeiro direto, sem restrições;
h) abertura comercial;
i) privatização das estatais;
k) direito à propriedade intelectual.

Elas deveriam ser aplicadas, sobretudo, na América Latina, acabando por se espraiar pelo mundo, partindo das ações de Pinochet no Chile, e se estendendo a Margareth Thatcher na Inglaterra, com o "Thatcherismo", e Ronald Reagan nos Estados Unidos, com a ideia da "economia pelo lado da oferta" (supply-side economics). Na prática, foram adotadas em dezenas de países, sem contestações e questionamentos, a princípio, vindo a ser rejeitada só por volta de 1997, depois da crise da Ásia, da "quebra da Rússia", que perdeu $30 \%$ do PIB, e da "quebra da Argentina", que recebia notas $A+$ do FMI pela presteza de alinhamento às medidas do "Consenso".

Não temos elementos de pesquisa para afirmar que a correlação entre crescimento da economia nacional produza efeitos comprovados e sistêmicos na economia dos clubes, mas pode-se perceber o aumento de receita em vários casos. Sem dados suficientes, pois não foi a isso que a pesquisa se propôs; para conclusão científica, porém, pode-se observar que o ambiente gerado pela economia brasileira, seja na ascensão como no descenso, se alinha a impacto no mesmo sentido na economia do futebol, fato que deve ser considerado.

Os clubes não cuidaram nem cuidam desse aspecto estrutural, e o que desejamos é chamar a atenção para a relevância de se trabalhar tal relação no planejamento da matriz econômica que sustentará cada entidade. 
O próprio John Williamson, criador da expressão "Consenso de Washington", acusou a deturpação da ideia original:

\begin{abstract}
"Claro que eu nunca tive a intenção que meu termo fosse utilizado para justificar a quintessência do pensamento neoliberal, qual seja, a liberalização de contas de capital externo, monetarismo, supply-side economics ou minarquia".
\end{abstract}

Porém, o conceito ganhou asas e, inevitavelmente, atingiu as atividades econômicas de toda ordem, chegando ao futebol. O Manchester United, até hoje um ícone internacional do clube-empresa e ainda um dos maiores faturamentosno mundo, acima de Real Madrid e Barcelona, se serviu da onda do Consenso de Washington para justificar e implantar nova filosofia de administração ancorada na relevância e necessidade da busca do sucesso financeiro.

Martin Edwards ${ }^{66}$, que substituiu o pai e não era um torcedor fanático, combinou o fracasso das empresas da família com a necessidade de ter lucro no Manchester United. Houve uma transição na filosofia de administração entre 1978 e 1981, como registra Leoncini (2001) ${ }^{67}$, Martin tentou realizar os investimentos de seu pai e quase vendeu o clube em 1989, mas nunca gerou lucros expressivos.

Segundo Leoncini, Martin Edwards desejava consagrar a máxima: "clube de futebol pode e deve gerar lucros". Isso contribuiu decisivamente para o processo que fez emergir a chamada economia do futebol. A necessidade de títulos foi agregada à filosofia que se consolidou na ideia: clubes de futebol devem gerar lucros, além do desempenho em campo. O Manchester foi o segundo clube de futebol inglês a ter ações na Bolsa de Valores, transformando-se numa "public company", ou seja, uma empresa de capital aberto. O peso histórico e esportivo do clube foi determinante no processo então iniciado e também estimulou a questão

66 Charles Martin Edwards foi o presidente do Manchester United de 1980 até 2002. Ele agora ocupa o cargo de presidente honorário da vida no clube e diretor da Inview Technology Ltd.

67 LEONCINI, Marvio Pereira. Entendendo o negócio futebol: um estudo sobre a transformação do modelo de gestão estratégica nos clubes de futebol. 2001. 168 f. Tese (Doutorado em Engenharia) - Escola Politécnica, Universidade de São Paulo, São Paulo, 2001. 
central desse trabalho que é a relevância do estádio como fonte de receita de um clube.

LEONCINI (2001) escreve:

\begin{abstract}
"Contudo, além de ser usado para pagar os empréstimos que a família Edwards fez para saldar as dívidas, que a família fez ao longo dos anos, na sua busca para obter o domínio acionário do Manchester,o dinheiro da série de venda de ações do clube na Bolsa de Valores deu a Martin a possibilidade de restaurar o estádio e, finalmente, ganhar dinheiro". (LEONCINI, 2001).
\end{abstract}

O Consenso de Washington contribuiu para o processo de transformação dos clubes em empresas,e para a chamada "financeirização" que no caso dos clubes, na prática, correspondia não só a perseguir resultados econômicos como também a implantar normas profissionais na administração com racionalidade, impessoalidade e responsabilização dos dirigentes pelos atos de administração. Isso trouxe duas consequências: a melhoria na gestão nos clubes contemplados e o movimento de elitização dos estádios, já que passaram a ser ativos financeiros a serem explorados e rentabilizados, suscitando dicotomia nada simples, não fácil até hoje de ser gerencida, mas passível de solução harmônica.

$\mathrm{Na}$ Inglaterra, além do procedimento do Manchester United, outro vetor propulsionou a organização dos clubes e a valorização do futebol, tratando-o como espetáculo da indústria da cultura: o Relatório Taylor68 "Taylor's Report" depois do desastre de Hillsborough ${ }^{69}$, em 15 de abril de 1989, em Sheffield, onde pereceram 96 pessoas e 766 ficaram feridos. Foi o maior desastre da Inglaterra em campos de futebol e um dos maiores do mundo. As causas estavam profundamente ligadas à insegurança no estádio, à atuação deficiente da polícia e ao descuidado com o planejamento dos jogos de futebol.

Tal fato foi seminal na criação do "estádio seguro". Na ocasião, Lord Justice Taylor publicou a versão definitiva em 1990, onde as diretrizes e normas adotadas

68 O Relatório Taylor é um documento sobre as consequências e as causas do desastre de Hillsborough, em 1989. sEU desenvolvimento foi supervisionado por Lorde Taylor de Gosforth.

69 A "Tragédia de Hillsborough" foi um incidente que ocorreu em 15 de abril de 1989 no Estádio Hillsborough, em Sheffield, durante o jogo entre Liverpool FC e Nottingham Forest, válido pelas semifinais da Taça da Inglaterra. 
balizaram a reestruturação dos estádios na Inglaterra, com forte repercussão no mundo. A chamada "Tragédia de Hillsborough" veio na sequência do desastre do estádio de Heysel ${ }^{70}$, na final da Copa dos Campeões da Europa, a mais importante do Continente, no jogo entre Liverpool e Juventus em 1985, com participação aguda dos "hooligans"71, torcedores violentos da Inglaterra. A reiteração da catástrofe implicou séria reação e se transformou num marco na luta pelo afastamento dos "hooligans" e torcedores inadequados.

Em paralelo, com a retirada dos "hooligans" ocorreu a elitização dos estádios, que se espraiou pouco a pouco pelo mundo, contemplando o Brasil de forma significativa somente a partir da preparação para a Copa do Mundo de 2014, com a construção dos estádios-shopping.

Como decorrência desse movimento mundial, amparado pelo Relatório Taylor, e a transformação do Manchester United em clube-empresa de capital aberto, lançou-se também a semente da transformação da relação do torcedor com o clube, que migrou do torcedor-apaixonado incondicional, que frequentava qualquer estádio para ver o clube do coração, para torcedor cliente - clube empresa, pautada pelo fundamento do marketing: quem manda é o cliente. Os desejos e idiossincrasias do cliente, que se propunha a pagar o elevado preço dos ingressos, passaram a conduzir a forma como o estádio o recebia.

Assim como nos anos $\mathrm{JK}$, não só o crescimento do país impulsionou o futebol, como também o otimismo vigente, que contagiava a sociedade brasileira, a suscitar o desejo de mudança e progresso em vários setores, inclusive o futebol, o clima do final da década de 80 e início dos anos 90 empolgou a absorção das ideias liberais aguçadas pelo Consenso de Washington.

O lucro do Manchester United no início da década de 90, já com ações na Bolsa de Valores, era cerca de 170 mil dólares. Em 1997 atinge 46 milhões de

\footnotetext{
70 A tragédia do Estádio do Heysel, na Bélgica, ocorreu no dia 29 de maio de 1985, quando estava para ser disputada a final da Taça dos Campeões Europeus, que opunha o Liverpool, da Inglaterra, e a Juventus, da Itália.

71 Hooliganismo (para a língua portuguesa do inglês hooligan, "vândalo"), refere-se a um comportamento destrutivo e desregrado, comumente associado a fãs de desportos, principalmente adeptos de futebol e universitários.
} 
dólares, o preço das ações quintuplicaram, o faturamento anual chegou a 200 milhões de dólares e o valor de mercado ultrapassou 1,5 bilhão de dólares.

Em paralelo, na FIFA, João Havelange, que assumiu a entidade em 1974 com receitas de 78 milhões de dólares, deixou o cargo apenas em 1998, com o estratosférico faturamento de 4 bilhões de dólares, cerca de 23,5 vezes o faturamento dos tempos anteriores, numa sólida aliança com a Coca-Cola e a família Dassler ${ }^{72}$, proprietária da Adidas. O futebol ingressara, sem retorno, no ciclo capitalista, na indústria do entretenimento.

O Brasil foi marcado por característica singular: todos os processos de mudança e o de crescimento e planejamento provocados pelos anos JK; e o de financeirização dos anos 90 acima citados, mexeram com o faturamento dos clubes, mas não com a modernização da gestão. No campo de jogo atingiam a Seleção nacional, mas não os clubes, que mesmo com arrecadações maiores mantinham-se mal administrados, repletos de dívidas e submetidos ao controle político e econômico da CBF e Federações. Os clubes não queriam ser "livres economicamente", os dirigentes apreciavam gerir a riqueza em causa própria ou a fim de conquistas imediatas, pontuais, que não eram projetadas para serem permenentes. Os clubes se contentavam metaforicamente em sair da senzala e adentrar a casa grande da CBF, ocupando um lugar no canto da mesa da sala de jantar.

O ambiente mais arcaico vigia nos clubes de futebol do Brasil, inclusive os maiores, mais potentes e tradicionais, que exerciam o papel de "puxar para baixo" o que qualquer espírito renovador tentava elevar, num exemplo clássico do antagonismo formal, capítulo desse trabalho.

\subsection{Consolidação e Realidade}

Hoje, os números do futebol atingem valores jamais imaginados no início do século XX e até mesmo em meados dele. Afinal, como já mencionado, só no Brasil

72 Adolf "Adi" Dassler foi um sapateiro e empresário alemão que começou a produzir sapatilhas nos anos 1920, junto a seu irmão Rudolf Dassler, em Herzogenaurach, próximo de Nuremberg. Fundador da empresa de material esportivo Adidas. 
foram movimentados $\mathrm{R} \$ 52,9$ bilhões em 2018, demonstrando o expressivo impacto econômico, politico e social causado pelo setor, dada sua ampla e relevante participação no PIB dos países ao redor do mundo.

Nesse contexto, importante destacar os principais dados constantes do Relatório Anual PLURI - Gigantes das Américas, 2018, publicado pela Pluri Consultoria ${ }^{73}$ em 02 de abril de 2019:

(a) a receita dos 50 maiores Clubes das Américas atingiu US\$2,9 bilhões anuais;

(b) em 2017, 70\% dos 50 maiores clubes das Américas apresentou crescimento de Receitas, sendo Botafogo o clube com maior crescimento, seguido por Grêmio e Chapecoense; o Flamengo aparece

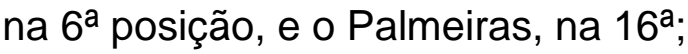

(c) os clubes brasileiros representam mais da metade (54\%) do faturamento dos 50 maiores clubes da região, seguido pelos EUA com $21 \%$ e pela Argentina com $17 \%$, sendo que os $8 \%$ restantes ficam com os demais países;

(d) os 165 clubes que disputam as 9 principais ligas e campeonatos de $1^{\text {a }}$ divisão das Américas faturaram em conjunto US\$3,744 bilhões em 2017, o que equivale a uma média de US\$22,7 milhões por clube, sendo que a receita dos TOP 30 Clubes das Américas equivale a 23\% dos TOP 30 Europeus:

${ }^{73}$ Empresa de Consultoria que deu origem ao GRUPO PLURI, composto por 7 empresas atuando nos setores de Esportes e Entretenimento, com foco em Consultoria em Gestão, Governança, Finanças e Marketing Esportivo para Clubes, Entidades e Atletas (www.pluriconsultoria.com.br) 
Tabela 18 - TOP 50 Clubes com maiores Receitas das Américas

\begin{tabular}{|c|c|c|c|c|c|}
\hline \multicolumn{2}{|c|}{ Rank } & \multirow[t]{2}{*}{ Clube } & \multirow[t]{2}{*}{ Pais } & \multicolumn{2}{|c|}{ Receita US\$ Milhōes } \\
\hline 2017 & 2016 & & & 2017 & 2016 \\
\hline 1 & 1 & Flamengo & Brasil & 203,2 & 146,3 \\
\hline 2 & 2 & Palmeiras & Brasil & 157,8 & 137,0 \\
\hline 3 & 5 & São Paulo & Brasil & 151,2 & 112,8 \\
\hline 4 & 4 & River Plate & Argentina & 126,7 & 118,8 \\
\hline 5 & 3 & Corinthians & Brasil & 122,6 & 139,2 \\
\hline 6 & 6 & Boca Juniors & Argentina & 113,9 & 105,3 \\
\hline 7 & 11 & Cruze iro & Brasil & 107.9 & 68,4 \\
\hline 8 & 12 & Grêmio & Brasil & 106,9 & 65,6 \\
\hline 9 & 7 & Atlético Mineiro & Brasil & 97,5 & 90,7 \\
\hline 10 & 8 & Santos & Brasil & 89,9 & 84,9 \\
\hline 11 & 20 & Botafogo & Brasil & 87,9 & 45,9 \\
\hline 12 & 10 & Internacional & Brasil & 77,0 & 83,9 \\
\hline 13 & 9 & Fluminense & Brasil & 71,8 & 84,1 \\
\hline 14 & 13 & LA Galaxy & EUA & 63,0 & 63,0 \\
\hline 15 & 14 & Vas co da Gama & Brasil & 60,0 & 61,2 \\
\hline 16 & 17 & Racing & Argentina & 53,2 & 51,1 \\
\hline 17 & 15 & Seattle Sounders & EUA & 52,0 & 53.0 \\
\hline 18 & 22 & San Lorenzo & Argentina & 50,8 & 43,1 \\
\hline 19 & 18 & Athletico Paranaense & Brasil & 50,5 & 47,1 \\
\hline 20 & 19 & Toronto FC & Canadá & 49,0 & 46,0 \\
\hline 21 & 21 & Portland Timbers & EUA & 48,0 & 44,0 \\
\hline 22 & 16 & Atlético Nacional & Colômbia & 47,5 & 52,8 \\
\hline 23 & - & Atlanta United & EUA & 47,0 & 0,0 \\
\hline 24 & 30 & Orlando City SC & EUA & 44,0 & 33,0 \\
\hline 25 & 23 & Independiente & Argentina & 43,0 & 42,7 \\
\hline 26 & 28 & New York City FC & EUA & 42,0 & 34,0 \\
\hline 27 & 25 & Sporting Kansas City & EUA & 41,0 & 36,0 \\
\hline 28 & 32 & New York Red Bulls & EUA & 38,0 & 32,0 \\
\hline 29 & 33 & Coritiba & Brasil & 37,3 & 31,5 \\
\hline 30 & 28 & San Jose Earthquakes & EUA & 36,0 & 34,0 \\
\hline 31 & 26 & Velez Sarsfield & Argentina & 34,3 & 35,6 \\
\hline 32 & 34 & FC Dallas & EUA & 34,0 & 30,0 \\
\hline 33 & 24 & Sport Recife & Brasil & 33,0 & 37,2 \\
\hline 34 & 27 & Bahia & Brasil & 32,9 & 34,6 \\
\hline 35 & - & Chapecoense & Brasil & 31,3 & 19,3 \\
\hline 36 & 46 & Barcelona Guayaquil & Equador & 29,1 & 21,7 \\
\hline 37 & 45 & Universidad de Chile & Chile & 28,2 & 22,1 \\
\hline 38 & 37 & Houston Dynamo & EUA & 28,0 & 26.0 \\
\hline 39 & 35 & New England Revolution & EUA & 28,0 & 27,0 \\
\hline 40 & 31 & Vitória & Brasil & 27,6 & 32,1 \\
\hline 41 & 41 & Chicago Fire & EUA & 27,0 & 25,0 \\
\hline 42 & 36 & Colo Colo & Chile & 27,0 & 26,6 \\
\hline 43 & 41 & Philade Iphia Union & EUA & 26,0 & 25,0 \\
\hline 44 & 41 & D.C. United & EUA & 26,0 & 25,0 \\
\hline 45 & 40 & Rosario Central & Argentina & 24,7 & 25,8 \\
\hline 46 & - & Newells Old Boys & Argentina & 24,4 & 17,7 \\
\hline 47 & - & Deportivo Cali & Colômbia & 24,2 & 16,3 \\
\hline 48 & 37 & Estudiantes & Argentina & 24,1 & 26,0 \\
\hline 49 & 41 & Montreal Impact & Canadá & 24,0 & 25,0 \\
\hline 50 & 37 & Columbus Crew & EUA & 24,0 & 26,0 \\
\hline
\end{tabular}

Fonte: Relatório Anual PLURI - Gigantes das Américas 2018 - 02/04/2019 $\left(^{*}\right)$ Excluíndo clubes Mexicanos, que não apresentaram seus balanços. 
Tabela 19 - 30 Clubes mais valiosos das Américas em 2018

\begin{tabular}{|c|c|c|}
\hline Clube & País & Valor - US\$ milhões \\
\hline Corinthians & Brasil & 462,2 \\
\hline Palmeiras & Brasil & 424,1 \\
\hline Los Angeles FC & EUA & 406 \\
\hline New England Revolucion & EUA & 351,2 \\
\hline Grêmio & Brasil & 313 \\
\hline Chivas & México & 297,1 \\
\hline Monterrey & México & 281,8 \\
\hline New York Red Bulls & EUA & 264,1 \\
\hline River Plate & Argentina & 219,1 \\
\hline Boca Juniors & Argentina & 213,1 \\
\hline Internacional & Brasil & 201,1 \\
\hline Galaxy & EUA & 200,1 \\
\hline Orlando City & EUA & 188,1 \\
\hline Flamengo & Brasil & 178,8 \\
\hline América & México & 174,8 \\
\hline Santos & México & 164,6 \\
\hline São Paulo & Brasil & 156,4 \\
\hline Real Salt Lake & EUA & 145,2 \\
\hline Tijuana & México & 140 \\
\hline Athetico Paranaense & Brasil & 137,2 \\
\hline Independiente & Argentina & 136,2 \\
\hline San Jose & EUA & 126,6 \\
\hline Pumas & México & 125,3 \\
\hline Toluca & México & 116 \\
\hline Santos & Brasil & 110,3 \\
\hline Vasco da Gama & Brasil & 103,4 \\
\hline Atlanta & EUA & 100 \\
\hline Tigres & México & 93 \\
\hline Racing & Argentina & 91,3 \\
\hline Vancouver & Canadá & 91,2 \\
\hline
\end{tabular}

(*) fonte: https://forbes.com.br/listas/2018/08/ acesso em 31/01/2020 
Tabela 20 - 20 Clubes mais valiosos da Europa em 2018

\begin{tabular}{|ccc|}
\hline Clube & País & Valor - US\$ bilhões \\
\hline Manchester United & Inglaterra & 4,12 \\
\hline Real Madrid & Espanha & 4,09 \\
Barcelona & Espanha & 4,06 \\
\hline Bayern de Munique & Alemanha & 3,06 \\
Manchester City & Inglaterra & 2,47 \\
Arsenal & Inglaterra & 2,24 \\
Chelsea & Inglaterra & 2,06 \\
Liverpool & Inglaterra & 1,94 \\
Juventus & Itália & 1,47 \\
\hline Tottenham & Inglaterra & 1,24 \\
\hline Paris Saint-Germand & França & 971 \\
Borussia Dortmund & Alemanha & 901 \\
Atlético de Madri & Espanha & 848 \\
West Ham & Inglaterra & 754 \\
Schalke 04 & Alemanha & 707 \\
Roma & Itália & 618 \\
Milan & Itália & 612 \\
Inter de Milão & Itália & 606 \\
Leicester & Inglaterra & 500 \\
Napoli & Itália & 471 \\
\hline (*) fonte: https://forbes.com.br/listas/2018/06/acesso em 31/01/2020 & \\
\hline I &
\end{tabular}

Da observância dos dados acima compilados, resta evidente que o montante de recursos envolvidos nas divesas atividades ligadas ao futebol não pode ser desprezado, e mais: os investimentos no setor tendem a crescer ainda mais, segundo estudos desenvolvidos por especialistas.

Uma vez superado o ambiente arcaico vivido no país, atualmente dirigentes de alguns dos clubes brasileiros vêm buscando alternativas para as respectivas crises financeiras, em especial novas formas de gestão, inclusive dispensando maior atenção aos estudos desenvolvidos acerca do tema, o que é extremamente positivo e alentador. Além das respectivas crises financeiras, tal mudança de postura é devida, em grande parte, à proporção alcançada pelos recursos manejados pelos clubes e atividades relacionadas ao esporte, denotando a dimensão da Nova Economia do futebol. 
Nesse contexto, importante destacar a análise efetuada pelo advogado Pedro Trenghouse ${ }^{74}$, um dos defensores do projeto "clube-empresa", que segundo ele, aproxima à realidade um ideal de que o futebol brasileiro será alvo de investidores. Em entrevista concedida a $\mathrm{O} \mathrm{GLOBO}^{75}$, o Professor afirma que "o futebol profissional hoje é negócio de bilhões e não pode continuar sendo administrado por estruturas criadas para contar tostões. Onde tudo é de todos, nada é de ninguém".

Afirma, ainda, que a legislação pátria precisa ser adaptada para possibilitar a pavimentação do caminho necessário à mudança no modelo de gestão dos clubes de futebol no Brasil, razão pela qual apoia a aprovação, pela Câmara dos Deputados, do projeto de lei que incentiva os clubes a virarem empresa ${ }^{76}$. Nele estão previstos incentivos fiscais para os clubes que se organizarem como empresas, um regime tributário mais favorável que o atual e um programa especial de quitação acelerada das dividas fiscais, dentre outras alterações, impactando de maneira significativa todo o mecanismo produtivo do futebol brasileiro. O professor Pedro Trenghouse tem se dedicado bastante ao tema e procurado mostrar a importância de se entender essa nova fase do futebol profissional que está inserida na economia desse esporte. Ele tem proferido várias palestras e participado de debates sobre o assunto.

Questionado acerca da existência de um modelo de gestão futebolística que seja indiscutível, o Professor destaca:

"Em regra, associação sem fins lucrativos não serve para gestão de futebol profissional. Exemplos como Inglaterra, França, Alemanha, Itália, Portugal e Estados Unidos onde a esmagadora maioria dos clubes é empresa evidenciam isso. Mesmo na Espanha, onde a lei que obrigou clubes a se organizarem como empresas previu uma exceção para associações que tivessem resultado operacional positivo nos últimos anos, clubes que se mantiveram como

\footnotetext{
${ }^{74}$ Professor de Direito Desportivo da FGV e presidente da Comissão da OAB que trata de jogos e loterias (tema que, segundo ele, dialoga com o projeto "clube-empresa".

75 https://oglobo.globo.com/esportes/clube-empresa-futebol-negocio-de-bilhoes-nao-paracontar-tostoes-diz-trengrouse-24107775

${ }^{76}$ PL 5.082/2016 - Clube-empresa, do Deputado Federal Pedro Paulo (DEM-RJ). Aprovado no Plenário da Câmara dos Deputados em 27/11/2019. Aguarda aprovação do Senado Federal.
} 
associação pagam impostos e a diretoria é obrigada a prestar garantia financeira para a gestão, colocando seu patrimônio pessoal em jogo como se fossem os donos de uma empresa." (entrevista a $\mathrm{O}$ GLOBO, 2019)

Ainda sobre as vantagens dos clubes associativos se transformarem em empresas, Trenghouse ressalta que normas aplicáveis às sociedades empresárias, como a responsabilidade dos sócios, a possiblidade de abertura de capital, emissão de debêntures e atração de investimentos com segurança jurídica, dentre outros, são fatores positivos e incentivadores da eficiência na gestão.

Diante do cenário apresentado, é fundamental que os clubes brasileiros se adaptem à nova realidade: a nova Economia do Futebol. Isso somente será possível através de gestões sérias e responsáveis, além da efetiva e eficiente utilização dos ativos disponíveis, aptos à geração de receita e alteração da matriz econômico-financeira dos clubes de futebol.

\subsection{A Economia do Futebol nos dias atuais}

Os dias atuais são conformação veemente da consolidação da Economia do Futebol, com o alcance de cifras jamais imaginadas para os valores dos clubes, das respectivas marcas, dos elencos, mensurados pela multas rescisórias dos atletas que os integram; valores de transferências, com destaque para a entrada de novos proprietários de clubes: pessoas físicas com patrimônio elevadíssimo, "sheiks" árabes, milionários de toda parte, empresas do mundo financeiro e fundos patrimoniais e de investimento. O futebol como negócio se impôs de forma avassaladora, embora a questão do mérito técnico, da tradição e "glamour" das competições perdure e, em alguns casos, resista ao assédio e à ocupação.

A Roma está sendo negociada pelo grupo empresarial James Palotta por U\$ 780 milhões com o Dan Friedkin, presidente do grupo Gulf State; o Milan, cujo maior acionista era Sílvio Berlusconi, magnata do meio de comunicação, foi vendida ao chinês Youghong Lee, e depois para o fundo norte-americano Elliot; a Fiorentina, que pertencia à família Della Valle, passou para o comando do norteamericano Rocco Comisso; o Bologna, comprado pelo empresário ítalo-canadense 
Joey Saputo; a Internazionale saiu do controle do italiano Massimo Moratti e foi adquirida pelo indonésio Erick Thohir, e mais tarde para o grupo Suning, onde Zhang Jindong é o maior acionista. O futebol não só foi envolvido por uma enxurrada de dinheiro como globalizou-se, com clubes tradicionais deixando de pertencer a associados ou proprietários dos países de origem, rumando para 0 controle de pessoas ou grupos empresariais e financeiros de países sem qualquer tradição cultural com o esporte.

O Manchester City, clube mais valioso em 2019, estimado em 4,8 bilhões de dólares, passou a ser propriedade do sheik Mansour; o Chelsea foi adquirido pelo milionário russo Roman Abramovich em 2003; o Manchester United pertence ao grupo norte-americano Malcolm Glazer; o Arsenal, em 2007, passou para os grupos dos empresários Stan Kroenke, EUA, e Alisher Usmanov do Uzbequistão, sendo que em 2018 o grupo Kroenke \& Entertainement adquiriu as ações de Usmanov por 550 milhões de libras esterlinas.

Os elencos dos clubes passaram a ter valor estratosférico se comparados ao passado, cerca de 30 anos antes. Atualmente o mais valioso atinge a avaliação de 1,3 bilhão de dólares, segundo dados divulgados pela "Transfermarkt". Os jogadores têm seus direitos federativos cotados em centenas de milhões de dólares e não são poucos. Os salários alcançam cifras inimagináveis. Diferentemente do tempo em que Gilmar dos Santos Neves já era goleiro campeão mundial de futebol e trabalhava meio-período como funcionário público na Secretaria da Fazenda do Governo do Estado de São Paulo para completar os rendimentos, dado que ganhava um salário no futebol parco e insuficiente.

O "futebol como negócio" é hoje uma realidade inquestionável. Contudo, não é inexorável deixá-lo só por conta do movimento natural do mercado financeiro que o abarcou, o que traria vários efeitos colaterais nocivos, sobretudo na relação com o torcedor.

Apesar dos números e evidências comportamentais de agremiações no exterior, estabelecida a dimensão da Nova Economia, os clubes demoraram para enxergá-la como fator relevante para a constituição de suas respectivas matrizes de sustentação financeira. Por receio de lidar com o desconhecido ou por não ser 
conveniente ao descontrole que permite o patrimonialismo e a gestão irrefletida, optaram por ignorá-la. Também foi assim na Sociedade Esportiva Palmeiras. Porém, ocorre que a dinâmica econômica não se detém diante do alheamento à sua realidade. De alguma forma ela vai pressionando e até encurralando as atividades contempladas no mercado, funcionando como um fluxo de água gigantesco à montante que, em certo instante, transpassa a barragem. Onde existe a capacidade de geração de riqueza, a dinâmica econômica vai atrás e captura o ativo. A economia do futebol não poderia continuar a ser ignorada por haver um fluxo de recursos e oportunidades que não era possível, então, ser mantido submerso. No caso do Palmeiras, a Economia do Futebol adentrou pela porta do Allianz Parque.

Tal ativo passa a ter valor impossível de ser negligenciado, sobretudo quando seus resultados nas receita do clube são significativos e acenam para a tão desejada autonomia, percebida apenas com a geração dessas receitas.

Desse modo, o estádio se transforma em ativo econômico relevante. 


\section{CAPÍTULO III - A HISTÓRIA E O ESTÁDIO COMO ATIVO ECONÔMICO}

\subsection{Copa do Mundo de 2014}

Em 30 de outubro de 2007 a FIFA anunciou oficialmente que a Copa do Mundo de 2014 seria realizada no Brasil. Como o país não tinha estádios com a qualidade exigida pela entidade, de pronto estabeleceu-se a necessidade de construí-los dentro do padrão oficial denominado "Padrão-FIFA", que contém conjunto de requisitos a certificar o modelo aludido, obrigando o Brasil a providenciar os equipamentos.

Tal exigência não contemplou tão-somente os estádios que seriam sedes dos jogos do torneio, estendendo-se a todos os outros planejados ou em início de obras naquele momento, uma vez que passariam a êmulos dos estádios da Copa, modernos em eventos esportivos, espaços de lazer e de cultura, além da disputa por sediar outras competições oficiais da FIFA e da Conmebol ${ }^{77}$. Foi essa diretriz que levou a WTorre, empresa que assumiria o direito de uso de superfície e seria a construtora do Allianz Parque, a projetá-lo totalmente dentro do padrão requerido, preocupando-se em fazê-lo com esmero, para obter vantagens competitivas concorrenciais. Assim se deu o primeiro e decisivo passo para o estádio-shopping.

A partir de então o processo ocorreu de forma incremental, por não haver, como já mencionamos, qualquer modelo de referência no país. Sander Van Stiphout $^{78}$, executivo da Amsterdam Arena Advisory - AAA, que administrava a arena holandesa, tinha interesse em gerir o Allianz Parque, e em conjunto com grupo de trabalho nomeado pelo diretor de Planejamento da Sociedade Esportiva Palmeiras, além de executivos de empresas interessadas na operação, foram lenta e gradualmente evoluindo na concepção do estádio, em conjunto com a WTorre.

77 A Copa Libertadores da América ou Taça Libertadores da América, oficialmente CONMEBOL ou simplesmente Libertadores, é a principal competição de futebol entre clubes profissionais da América do Sul, organizada pela Confederação Sul-Americana de Futebol desde 1960.

78 Diretor e vice-presidente de projetos da Amsterdam Arena International. 
Stiphout trouxe como contribuição mais significativa a sequência lógica do empreendimento: primeiro, estabelecer o conceito da arena, a seguir esboçar o plano de negócios básico e, depois, realizar o projeto de arquitetura, o "design", que seria consequência. E não como ocorria, e ainda ocorre no Brasil, partir do "design", que funciona como a estrutura monumental aludida no início do trabalho, para então adaptar a ele as outras características e equipamentos, o que leva , quase sempre, a inadequação e erros de concepção. O projeto do Allianz Parque, depois de respeitada a sequência acima citada, baseou-se nos trabalhos do arquiteto português Thomaz Taveira, que havia sido responsável por dois estádios em Portugal construídos para a Euro-2004, campeonato de seleções nacionais. Por conta, do plano de negócios, que incluía jogos e shows, fixaram-se as inclinações e distâncias, de modo a permitir melhor visibilidade e conforto dos espectadores, respeitando o "padrão-FIFA" para jogos de futebol.

O Allianz Parque foi um empreendimento inovador, com todas as características de pioneirismo, urdido por aproximações sucessivas entre o pensar e as possibilidades que surgiam ao longo do seu incremento. Não foi algo que chegou ao Brasil pronto, que se construiu baseado em planta de estádios de fora do país, embora, se lastreasse nos conceitos do que havia na Europa e Estados Unidos, sobretudo, com relação ao conforto e à condição de prover espetáculos não esportivos. Não havia paradigmas no Brasil, e partiu-se de uma conclusão econômica: só em São Paulo, com certeza, e, talvez no Rio de Janeiro, a ver, poder-se-ia pensar em empreendimento do tipo, naquele momento, com segurança de rentabilidade para o investidor privado

O Allianz Parque foi pioneiro na concepção estádio-shopping e desenvolveu um modelo peculiar que seria decisivo na criação da matriz econômica: estádio privado com financiamento totalmente privado, vindo diretamente do parceiro que iria explorar a cessão de direito de superfície. O proprietário do estádio, a Sociedade Esportiva Palmeiras, não colocou recursos próprios na construção do estádio, participando do empreendimento com a propriedade do terreno e de parte, pequena, do estádio, que se manteve durante o processo de reforma. A obra não foi tratada como construção de novo estádio, mas sim como uma grande reforma do estádio existente. O Palmeiras não assumiu nenhuma dívida quanto ao 
financiamento. Esse modelo se impôs não só pela decisão do Palmeiras e WTorre, como também pela concentração de recursos públicos nos estádios que sediariam a Copa. Tal política, transformou-se em algo benéfico para o Palmeiras, isentandoo de ônus financeiro e político.Estar fora do rol dos equipamentos oficiais para a Copa do Mundo foi fator decisivo e fundamental para a implantação do modelo que acabou por ser o mais eficiente e eficaz na consecução da matriz econômica.

Houve alguns modelos paralelos, como o do Maracanã, estádio público com financiamento público e gestor privado. A Arena Corinthians, estádio privado com financiamento público obtido junto ao Banco Nacional de Desenvolvimento Econômico e Social - BNDES, Caixa Econômica Federal - CEF, e o Morumbi ${ }^{79}$, que ficou excluído da Copa e não se adequou ao padrão-FIFA, insistindo em tentar reforma limitada, restando sem encontrar parceiros, transformando-se no modelo do estádio-arquibancada não aderente ao modelo modernizado da economia do futebol, embora tentasse concorrer com os outros por já sediar eventos culturais, propiciando bom exemplo de comparação entre o funcionamento do estádioarquibancada e do estádio-shopping.

O trabalho de pesquisa mostra a efetividade de cada um como ativo capaz de gerar receitas que levassem à matriz econômica sistêmica e sustentável de autonomia financeira, questão básica dessa tese. Só o estádio multiuso com as condições do Allianz Parque logrou o resultado que consolidou a matriz propalada, como veremos adiante no capítulo que compara tais modelos.

O ponto fundamental a ser reiterado e ressaltado, e que embasa a matriz econômica eficaz, é a não existência de recursos públicos e 0 não comprometimento financeiro do clube com a construção do estádio. O Palmeiras passou a usufruir apenas dos benefícios gerados pelas receitas extra-futebol e do significativo crescimento das fontes de receita oriundas do estádio nos eventos esportivos. Todas as receitas dos dias de jogos, excluindo as despesas operacionais, são do Palmeiras, e tal propriedade de direitos permite estruturar o programa de sócio-torcedor, com seus descontos e vantagens a arrecadar receita antecipada, previsível e sistemática, além de liberdade para a fixação de preços

79 O Estádio Cícero Pompeu de Toledo, mais conhecido como Estádio do Morumbi, inaugurado em 1930 e sede oficial do São Paulo Futebol Clube - SPFC. 
dos ingressos. O estádio-arquibancada, o Palestra Italia, nos seus derradeiros anos de funcionamento, 2013 e 2014, tinha custo fixo de manutenção em torno de $\mathrm{R} \$ 10.000 .000,00 / a n o$, além das despesas operacionais dos jogos. O Allianz Parque não tem custo de manutenção para o clube, que cabe à parceira WTorre, e tem fontes de receitas tanto dos eventos esportivos como de qualquer outra atividade existente, além de propriedades de marketing, tal qual publicidade. Houve importante inversão de significado do estádio na economia do clube: de passivo, gerador de despesas, a ativo, fornecedor de receitas.

A receita gerada permite independência com relação aos direitos pagos pela transmissão por TV, fonte majoritária em outros clubes, possibilitando que o Palmeiras possa estabelecer concorrência real sobre tais direitos, fazendo-o auferir mais dinheiro na comercialização desse ativo. Foi o que ocorreu com a venda para o Esporte Interativo, concorrente da Rede Globo de Televisão, que pagou só de luvas 100 milhões de reais para transmitir os jogos do Palmeiras em TV fechada canal a cabo, dos campeonatos brasileiros de 2019 a 2024. Tal recurso não poderia ter sido recepcionado, e nunca foi auferido em períodos anteriores, pela necessidade anterior de submissão à proposta que fazia a Rede Globo, que antecipava receitas para os clubes com a condição de aceitação de contrato integral, abrangendo TV aberta, TV fechada, sistema pagar-para-ver, pay-per-view e internet. Os clubes precisavam submeter-se ao conjunto dos meios citados, percebendo receita, no todo, menor. 


\section{Gráfico 05 - Valores pagos em 2017 pela Globo}
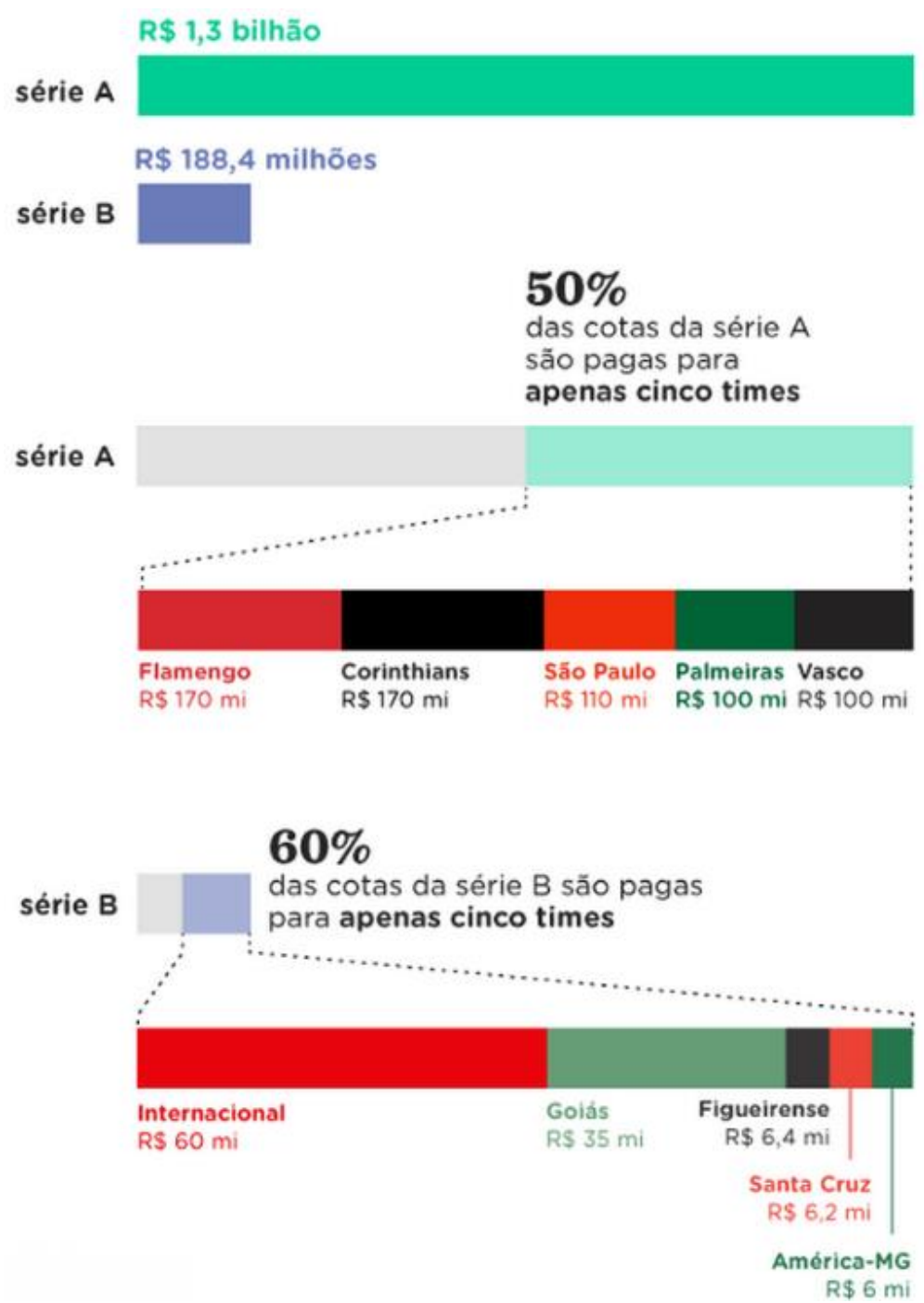

Fonte: Nexo Jornal - www.nexojonrla.com.br - Acesso em 10/10/2018

Quando se pensou pela primeira vez em reformar o Palestra Italia não havia a visão do estádio multiuso nem da modernidade. Seguia-se um mesmo modelo anterior de quando se executaram obras de reforma, nos anos 1950 e 1964, onde o objetivo principal não era criar ativo que viesse a ser fonte de receita e se tornasse relevante na equação de equilíbrio financeiro. O motivo maior determinante da reforma foi a sequência de intervenções da Prefeitura de São Paulo, impondo restrições ao uso do estádio por contrariar posturas municipais de segurança, remetendo à operação de alto custo financeiro. A cada campeonato, o Palmeiras se via na obrigação de realizar várias obras de manutenção e adequação para poder utilizar o estádio no campeonato seguinte. Custava caro e não 
resolvia a questão estrutural, além de agravar as despesas com manutenção do ano seguinte. Logo, a primeira ideia foi diminuir os custos de obras corretivas e manutenção, sem o vislumbre do papel que poderia ter o estádio.

Toda a história sobre esse processo contou com o relevante papel do conselheiro José Cyrillo Jr., coordenador da "Comissão do Estádio" e responsável direto pelo acompanhamento da manutenção e reforma perante a Prefeitura de São Paulo. Cansado daquele processo repetitivo e preocupante, além de cada vez mais custoso, o Palmeiras resolveu realizar uma grande reforma, porém nos mesmos moldes das anteriores, com foco em redução de custos de manutenção e ampliação da capacidade de espectadores. Não havia preocupação com quaisquer demandas que vieram, posteriormente, conduzir o trabalho de formulação do Allianz Parque no conceito de estádio que se voltava ao torcedor cliente, tomando o lugar do torcedor apaixonado, que ocupava sem exigências o estádio-arquibancada.

A falta de investidores para tal tipo de reforma simples, que não acrescentava nada ao panorama conhecido dos estádios, e a circunstância decisiva da Copa do Mundo, impulsionaram o projeto para o conceito de estádio-shopping, que, como vimos, não partiu de modelo já conhecido e acabado, mas foi sendo elaborado passo a passo, procurando harmonizar as necessidades do clube e as do parceiro candidato a administrar o direito de superfície a ser concedido.

A WTorre não fez a primeira incursão no negócio por intermédio do Allianz Parque. Anteriormente, a empresa havia procurado o Corinthians para construir estádio em terreno da Dow Química ${ }^{80}$ na marginal do rio Pinheiros. $O$ acordo não se consolidou, em grande parte por haver compromisso anterior do Corinthians com a $\mathrm{MSI}^{81}$, empresa que passou a administrar o futebol do

${ }^{80}$ A The Dow Chemical Company é uma corporação estadunidense de produtos químicos, plásticos e agropecuários, atuando em numerosos setores, com igualmente numerosos produtos.

${ }^{81}$ Micro-Star International Co. Ltda é uma empresa de produtos eletrônicos e de hardware sediada em Novo Taipé, Taiwan. É uma das maiores fabricantes de placas-mãe e placas de vídeo do mundo. 
clube e também se propunha a fazer um estádio. As idas e vindas desse negócio ofereceram à WTorre experiência sobre os pontos débeis do empreendimento "estádio de futebol" no Brasil. Os pontos cruciais eram a propriedade do terreno e a certeza de que o clube não iria provocar problemas no cumprimento do contrato. Por esse caminho chegou ao Palmeiras, e então se iniciou toda a história contada pelo condutor oficial do processo no Palmeiras, José Cyrillo Jr., e atestada pelos diretores da WTorre.

Foi uma longa e complexa transação, com as dificuldades inerentes ao inusitado negócio, além da já aventada não existência de referencial no Brasil, contribuíram largamente para a consecução do modelo hoje existente. Isso porque o modelo precisou ser desenhado passo a passo, demandando reflexão, pesquisa e planejamento, fatores raros em empreendimentos do tipo no Brasil.

Tal arquitetura se concretizou com o direito de uso de superfície constante no arcabouço jurídico vigente, a proporcionar solidez e segurança a ambas as partes; a não participação do clube no processo de financiamento; a plena autonomia do clube no uso do estádio em dias de jogos; a administração da WTorre nos dias em que não há jogos e o respectivo direito de promover eventos, espetáculos, reuniões, seminários empresariais; propriedade do direito de nomear o estádio, "naming rights ${ }^{82 " ~ e ~ a s ~ p o r c e n t a g e n s ~ d e ~ p a r t i c i p a c ̧ a ̃ o ~ d o ~ c l u b e ~ n a s ~ r e c e i t a s ~ v i n d a s ~}$ dos eventos e nas propriedades não-operacionais. Por ter capacidade abaixo dos 65.000 expectadores exigidos pela FIFA para sediar o jogo de abertura da Copa de 2014, o Allianz Parque não foi cogitado para o evento, isentando-se do que ocorreu com a Arena Corinthians, que após plano de estádio definido incluiu estrutura improvisada atrás dos gols para atingir os assentos requeridos, o que suscitou acréscimo de recursos e mudança no projeto, fato que até hoje agrava a equação financeira do estádio em Itaquera, comprometendo gravemente as finanças do Corinthians, sem uma solução conhecida até o início de 2020.

82 "Naming Rights" é a prática da concessão de direitos de nome que empresas donas de algum estabelecimento de espetáculos culturais e/ou esportivos dá o nome para uma marca ou produto. 
O Allianz Parque, por sua vez, escapou da armadilha do financiamento, contemplando modelo saudável e sustentável, isentando o clube de compromissos financeiros futuros atrelados à construção e permitindo receitas líquidas desde a sua inauguração. $O$ modelo transformou o estádio em ativo financeiro gerador de receita significativa, independente, sistêmica e permanente, sobretudo ao tornar-se âncora do programa de sócio-torcedor do Palmeiras, no Palmeiras denominado Sócio Avanti83.

\subsection{Allianz Parque}

\subsubsection{A Conversão do Palestra Italia no Estádio-Shopping}

O Estádio-Shopping muda a relação clube-torcedor, transformando o vínculo do torcedor apaixonado, que se dispõe a tudo para ver seu time atuar, ajustando-se às condições impostas pelo estádio, em relação subordinada; para conexões idênticas àquelas da indústria do entretenimento, onde o torcedor assume a condição de cliente; e o time de futebol, a de clube-empresa; e este precisa seduzir o torcedor, atrai-lo, não só a frequentar esporadicamente, mas com alta constância, em processo de fidelidade. O torcedor passa a ser um demandante, que estabelece as condições para assistir ao espetáculo, o jogo de futebol, e o clube procura organizar o tal espetáculo, nos mesmos cânones da indústria cultural. Essa é uma mudança crucial, uma inflexão que leva ao estádio-shopping.

Anteriormente a isso, já observava LEONCINI (2001): "o esporte, que nasceu dos jogos realmente populares, isto é, produzidos pelo povo, retorna ao povo sob a forma de espetáculos produzidos para o povo".

Estádio-shopping não se atém a ser simplesmente um palco para jogos de futebol, criando os espaços necessários para frequência fora dos dias de jogo, com shows, lojas, restaurantes e locais para reuniões sociais e empresariais. A concepção final do Allianz Parque, após o desenvolvimento dos estudos já mencionados, realizou-se sobre duas premissas: por parte do Palmeiras, com a

\footnotetext{
${ }^{83}$ Avanti Palmeiras é o programa de sócio torcedor da Sociedade Esportiva Palmeiras.
} 
ideia de fonte de receita, expressa claramente pelo seu diretor de Planejamento no período da formulação, Luiz Gonzaga de Mello Belluzzo; e por parte da WTorre, cessionária do direito de uso de superfície, com o objetivo de obter receitas com a promoção de atividades no estádio fora dos dias de futebol, sobretudo, mas também, durante os jogos, com a arrecadação por intermédio de camarotes de alta rentabilidade, e 10.000 cadeiras que ficaram, por disposição contratual, sob sua propriedade. Dessa forma erige-se o Allianz Parque, que não foi projetado oficialmente como nova construção e sim como uma reforma do antigo Palestra Italia, a resultar em complexo processo de obtenção do alvará de reforma, só efetivado em 2010. A obra se iniciou dois anos e três meses após a assinatura do contrato, ocorrida em julho de 2008, após o registro da escritura do acordo entre Palmeiras e WTorre.

Allianz Parque é um estádio que atende às normas da FIFA ${ }^{84}$, possuindo, portanto, o selo conhecido por "Padrão FIFA", e como estádio-shopping configurase em arena multiuso, apto a receber os mais categorizados eventos esportivos e artísticos. Foi construído pela empresa WTorre Properties/Arenas, do Grupo WTorre, com obra iniciada em 2010 e concluída em 2014. Atualmente é uma arena multiuso, para "shows" e se encontra entre aquelas com maior número de eventos ao ano no mundo, atestando a eficácia do os objetivos pretendidos e a visão da demanda do mercado de espetáculos em São Paulo.O estádio foi inaugurado em 19 de novembro de 2014 com o jogo Palmeiras e Sport do Recife, placar de 2x0 para os visitantes, com presença de 35.939 torcedores.

${ }^{84}$ Federação Internacional de Futebol Associação, mais conhecida pelo acrônimo FIFA, é a organização não governamental internacional que dirige as associações de futsal, futebol de areia e futebol. 


\section{Figura 07 - Estádio Allianz Parque}

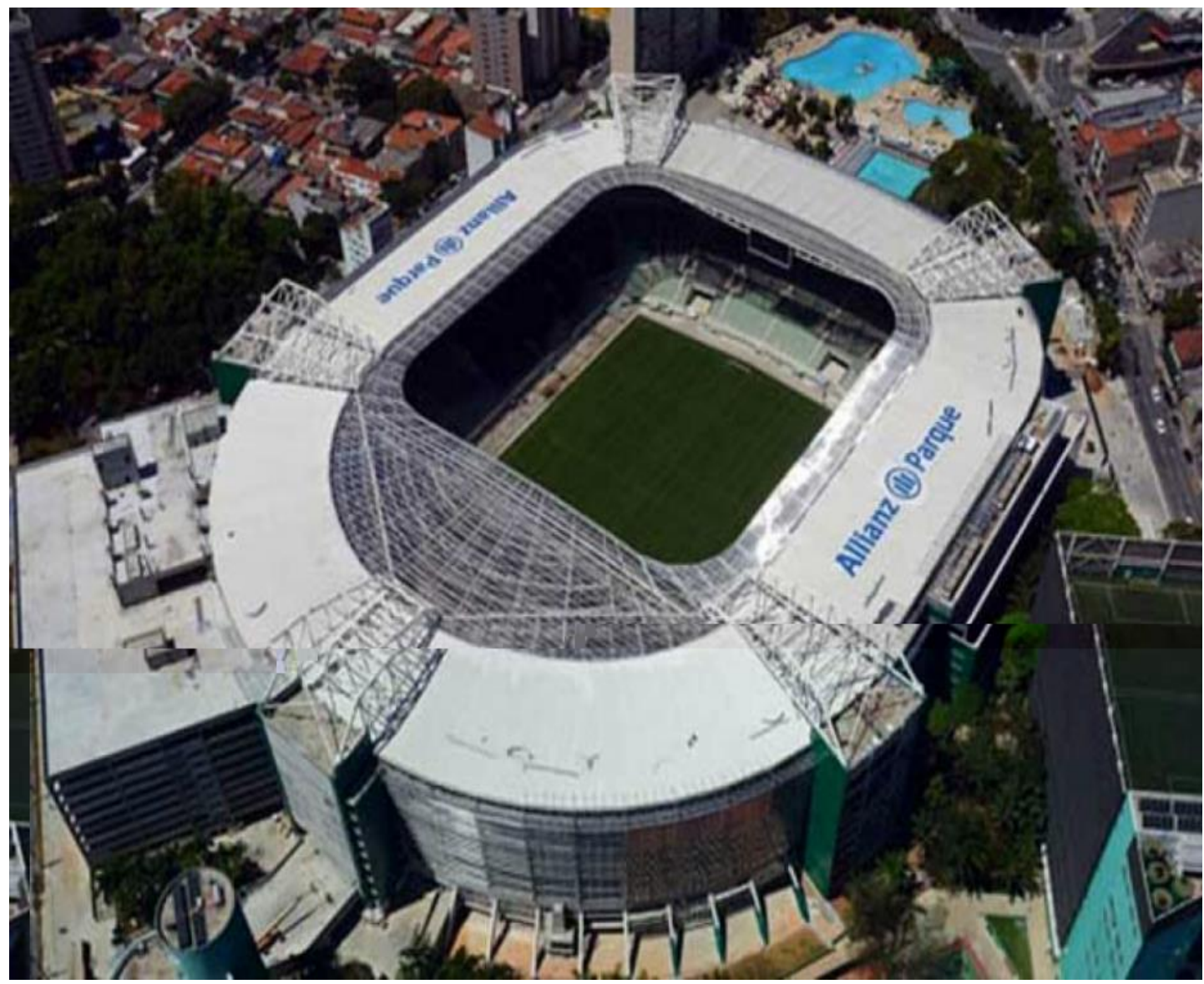

FonteJornal Lance! - www.lance.com.br - acesso em 11/04/2018

Ano do início da construção, 2010 registra o Produto Interno Bruto-PIB de $7,5 \%$ tratando-se da maior alta dos últimos 24 anos, fato que impulsiona 0 entusiasmo pela obra. Após crescer 4,7\% em média de 2004 a 2007 e expandir-se 5,2\% em 2008, o PIB regrediu 0,3\% em 2009, fruto da crise mundial chamada de "subprime" nos Estados Unidos da América. 


\section{Gráfico 06 - 100 anos de crescimento do PIB no Brasil (\%)}

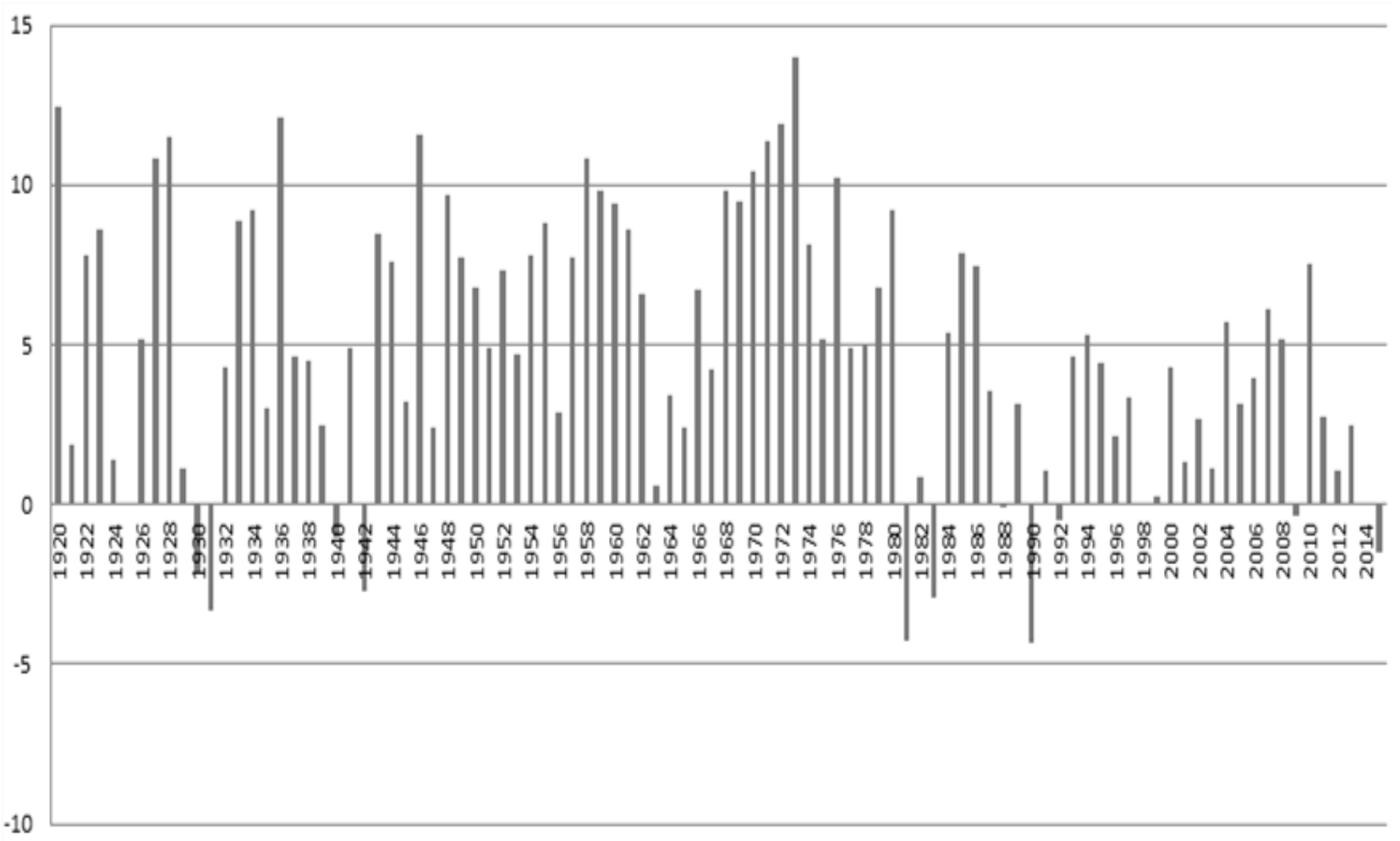

Fonte: 100 Anos de PIB no Brasil - www.paulogala.com.br- acesso em 11/04/2018

Quando o estádio é gestado, nos anos de 2007 e 2008, o ambiente reinante no país é de crescimento desde 2004, como acima referido, e o ano de 2009 não é tido como fator sistêmico de involução do crescimento por ser relacionado à falha no sistema bancário americano. O espírito de desenvolvimento foi robustecido pelo resultado expressivo de 2010, quando o crescimento do PIB atingiu $R \$ 3,675$ trilhões $\left(7,5 \%\right.$ a mais que 2009) ${ }^{85}$. Outra vez, idêntico às reformas do Parque Antarctica em 1933, que se transformou em Palestra Italia, e do próprio Palestra Italia em 1958, coincidem o tempo de crescimento, o descortinar de desenvolvimento do país e o espírito empreendedor com relação a modernização do estádio. Os dirigentes responsáveis pela iniciativa das obras, tanto em 1933, 1958 como em 2010, foram tangidos por ambiente instalado pelo crescimento econômico do Brasil, alicerçando o estímulo a novos investimentos, ao decidirem iniciar os trabalhos.

85 IBGE - Censo 2010 


\section{Tabela 21 - Padrão-FIFA}

\begin{tabular}{|c|c|}
\hline $\begin{array}{l}\text { Capacidade e } \\
\text { Assentos }\end{array}$ & $\begin{array}{l}\text { De acordo com as normas da FIFA, um estádio deve ter capacidade de, } \\
\text { no mínimo, } 30 \text { mil lugares sentados para receber uma partida de futebol } \\
\text { internacional, e ainda, mínimo de } 50 \text { mil para receber uma final de Copa } \\
\text { das Confederações, e mínimo de } 60 \text { mil para ter o privilégio de sediar uma } \\
\text { decisão de Copa do Mundo.Os assentos devem ser individuais e fixados, } \\
\text { com encostos com altura mínima de } 30 \mathrm{~cm} \text {. Recomendada a distância } \\
\text { mínima de } 80 \mathrm{~cm} \text { de encosto a encosto, A largura recomendado } 50 \mathrm{~cm} \text { e } \\
\text { devem ser identificados. }\end{array}$ \\
\hline $\begin{array}{l}\text { Toaletes e } \\
\text { instalações } \\
\text { sanitárias }\end{array}$ & $\begin{array}{l}\text { Recomenda-se no mínimo } 28 \text { sanitários e } 14 \text { pias para cada } 1.000 \\
\text { mulheres e } 3 \text { sanitários, } 15 \text { mictórios e } 6 \text { pias para cada } 1.000 \text { homens. }\end{array}$ \\
\hline $\begin{array}{l}\text { Dimensões do } \\
\text { campo de jogo }\end{array}$ & $\begin{array}{l}\text { O padrão adotado pela FIFA exige que o gramado dos estádios de futebol } \\
\text { tenha dimensões de } 105 \text { metros de comprimento por } 68 \text { metros de largura, } \\
\text { com área auxiliar as dimensões totais são as seguintes: comprimento de } \\
125 \mathrm{~m} \text { e largura de } 85 \mathrm{~m} \text {. A FIFA sugere que não haja barreiras entre o } \\
\text { campo e as arquibancadas. Dessa forma, para evitar invasões, } \\
\text { recomenda-se a presença constante de seguranças e policiais. }\end{array}$ \\
\hline $\begin{array}{l}\text { Instalações de } \\
\text { alimento e bebidas }\end{array}$ & Precisam ter: rapidez e qualidade de atendimento. \\
\hline Vestiários e acessos & $\begin{array}{l}\text { Jogadores e arbitragem devem ter à disposição uma área de entrada } \\
\text { segura e exclusiva, com espaço suficiente para circulação de carros, } \\
\text { ônibus e ambulâncias. Os vestiários, tanto para times da casa quanto para } \\
\text { visitantes, devem ter, no mínimo, } 150 \mathrm{~m}^{2} \text { e também itens de conforto } \\
\text { idênticos para ambos.O túnel de acesso ao campo de jogo deve ter, no } \\
\text { mínimo, } 4 \text { metros de largura por } 2,2 \text { metros de altura. Para sediar partidas } \\
\text { internacionais, o recomendado pela FIFA é o mínimo de } 6 \text { metros de } \\
\text { altura.Áreas de aquecimento devem ter a partir de } 100 \mathrm{~m}^{2} \text {. }\end{array}$ \\
\hline lluminação & $\begin{array}{l}\text { Para evitar apagões prolongados, o estádio deve contar com sistema de } \\
\text { geradores de energia com capacidade para funcionar por } 3 \text { horas. }\end{array}$ \\
\hline Segurança & $\begin{array}{l}\text { A segurança também é primordial. E isso deve ser considerado já no } \\
\text { projeto de construção do estádio, com itens como escadarias, portões e } \\
\text { corredores completamente livres de obstáculos. Os estádios devem contar } \\
\text { com uma sala de controle com visão panorâmica, assim como câmeras de } \\
\text { vigilância interna e externa. Sala de primeiros socorros é exigência básica }\end{array}$ \\
\hline $\begin{array}{l}\text { Conforto e } \\
\text { visibilidade }\end{array}$ & $\begin{array}{l}\text { A visão do campo deve ser perfeita de qualquer setor do estádio e as } \\
\text { placas de publicidade devem ter altura máxima de } 100 \mathrm{~cm} \text {. As normas de } \\
\text { acessibilidade devem ser adotadas com portão de entrada exclusivo, } \\
\text { rampas para cadeirantes, banheiros adaptados, assentos para } \\
\text { acompanhantes, tomadas elétricas e serviço de apoio. }\end{array}$ \\
\hline Mídia & $\begin{array}{l}\text { As cabines de imprensa devem ter localização central no estádio, com } \\
\text { uma mesa para cada estação, provida de tomadas de energia, conexão de } \\
\text { modem e telefone e uma televisão para cada oito estações.As cabines de } \\
\text { televisão e rádio também devem ter localização central, com estações } \\
\text { separadas e proteção acústica. O local deve contar com telefone, tomadas } \\
\text { de energia e uma televisão para cada estação.A sala de coletiva de } \\
\text { imprensa deve ter, no mínimo, } 100 \mathrm{~m}^{2} \text { e aproximadamente } 100 \text { assentos. } \\
\text { A zona mista, área entre os vestiários e a saída dos jogadores, deve } \\
\text { comportar ao menos } 250 \text { profissionais de comunicação. }\end{array}$ \\
\hline $\begin{array}{l}\text { Localização, } \\
\text { facilidade no acesso } \\
\text { e saída do público }\end{array}$ & $\begin{array}{l}\text { O estádio deve ser de fácil acesso por meio de transporte público e ter } \\
\text { estacionamento para carros e ônibus no entorno, além de hotéis, centros } \\
\text { comerciais e aeroportos nas proximidades. Heliporto no estádio ou bem } \\
\text { próximo a ele também é recomendado.Os estádios com capacidade para } \\
60 \text { mil torcedores devem ter, no mínimo, } 10 \text { mil vagas de estacionamento } \\
\text { para carros e } 500 \text { para ônibus. Eles podem ser adjacentes ao estádio ou } \\
\text { num raio de até } 1,5 \mathrm{~km} \text {.O acesso ocorre ao longo de uma hora e na saída, } \\
\text { todos desejarão sair quase ao mesmo tempo. }\end{array}$ \\
\hline
\end{tabular}

Fonte: FIFA - www.fifa.com acesso em 11/04/2018 
A história da consecução do projeto Allianz Parque não tem trajetória simples, obrigando seus executores a trabalho político intenso, numa batalha que levou anos dentro do Conselho Deliberativo do Palmeiras, e a aprofundamento técnico complexo, por não haver experiência anterior no Brasil, no sentido de um estádio multiuso. Os estádios erguidos para a Copa do Mundo de 2014 se constituíram no segundo ciclo de construção por atacado no Brasil. Houve um ciclo anterior nos anos 70 , todos no conceito estádio-arquibancada, por dentro, combinados com a ideia de monumentos, na arquitetura e aparência, tornando-se, a maior parte deles, obras sem a utilização planejada, chamados de "elefantes-brancos", que passaram de orgulho inicial a centro de despesas insustentáveis, gerando alta deterioração física.

Os estádios tinham sentido político, interessando às forças locais participar do benefício político do evento de corte da fita inaugural e depois se ausentar da respectiva manutenção, omitindo-se no planejamento orçamentário futuro as despesas e encargos com a respectiva manutenção. Eles não eram pensados para outro uso sistemático, recebendo vez ou outra, improvisadamente, espetáculos de entretenimento, sem nenhuma infraestrutura conveniente. Mesmo assim, o segundo ciclo de construção não cuidou de compatibilizar usos e circunstâncias, pensar no que contemplariam após a Copa do Mundo e como poderiam ser parte de equação financeira que visasse a sua autossuficiência, a princípio, e depois se tornassem fonte de receita sistêmica para os clubes de futebol. Outra vez, o sentido de construir monumentos para efeito de poder e glória sobrepujaram a racionalidade e a visão do que os estádios poderiam representar.

O estádio-shopping construído pela WTorre quebrou o paradigma de "monumentos deficitários", os chamados "elefantes-brancos". O Allianz Parque acabou por cumprir as etapas necessárias acima aludidas, com a primeira ideia sobre o conceito vinda de um executivo que atuava na Amsterdam Arena ${ }^{86}, 0$ estádio consagrado para shows e eventos no modelo multiuso. A Arena multiuso é o que denominamos, desde a introdução, de estádio-shopping. Esse conceito, vital

\footnotetext{
${ }^{86} \mathrm{O}$ Johan Cruijff Arena é um estádio localizado em Amsterdam, na província neerlandesa da Holanda do Norte, projetado para ser o estádio olímpico das Olimpíadas de 1992. É a casa do time de futebol AFC Ajax e do time de futebol americano da NFL Europa Amsterdam Admirals.
} 
para a transformação do Allianz Parque em rentável fonte de recursos, foi sendo trabalhado e aprimorado nas reuniões em que a construtora WTorre realizava com a equipe da diretoria de Planejamento do Palmeiras. Não foi uma ideia, como já vimos, que chegou pronta e se estabeleceu, foi sendo urdida gradualmente, adequando a experiência da Amsterdam Arena às condições brasileiras e às possibilidades específicas e limitações que o futuro Allianz Parque apresentava. Também teve papel relevante a oposição que o grupo de conselheiros ligados a Mustafá Contursi Goffar Majzoub efetuava, pois à medida que seu grupo apontava dificuldades, a equipe técnica responsável pela obra tratava de encontrar soluções, evitando a rejeição do projeto por parte da maioria do Conselho.

O caminho para a aprovação foi tortuoso e teve momentos de dramaticidade real, como a atitude do conselheiro Pasquale Bruno, que se atirou diante do trator que faria a demolição, causando estupor e indignação. $O$ instrumento que proporcionou autonomia financeira ao Palmeiras foi seriamente combatido por muitos conselheiros e autoridades do clube, mesmo depois de já iniciado, havendo uma descrença permanente quanto à conclusão da empreitada em 2014. Com a obra já em fase de acabamento foi registrado discurso em reunião oficial do Conselho Deliberativo do clube, de um conselheiro e vice-diretor jurídico do Palmeiras, em que ele aponta em direção ao estádio e questiona ceticamente: "Vocês acham que isso aí vai ficar pronto?".

De todo modo, tal resistência representou um desafio para os condutores do projeto, e assim o conceito de estádio-shopping foi ganhando sua forma e modelo definitivo, modelo que se mostrará adiante como diferenciado dos demais estádios concorrentes e fundamental para a formação da matriz econômica que o trabalho procura investigar. 
Tabela 22 - Dados do Estádio Allianz Parque

\begin{tabular}{|c|c|}
\hline \multicolumn{2}{|r|}{ Allianz Parque } \\
\hline Estacionamento & Capacidade para até 2.000 veículos \\
\hline Capacidade & $\begin{array}{l}\text { Jogos de futebol em estádio padrão FIFA para até } 43 \text { mil } \\
\text { pessoas. }\end{array}$ \\
\hline Capacidade Oficial & 43.713 \\
\hline Assentos & $\begin{array}{l}\text { Total de } 43 \text { mil assentos cobertos, pouco mais de } 3 \text { mil } \\
\text { encontram-se nas áreas premium, em dois andares exclusivos } \\
\text { que abrigam camarotes privativos, lounges e business club. } \\
\text { Cadeiras Inferiores: } 25.935 \\
\text { Cadeiras Intermediarias (camarotes): } 3.430 \\
\text { Cadeiras Superiores: } 14.888\end{array}$ \\
\hline $\begin{array}{l}\text { Shows - } \\
\text { Espetáculos }\end{array}$ & Shows para até 55 mil pessoas \\
\hline Teatro & Anfiteatro coberto para até 12 mil pessoas \\
\hline $\begin{array}{l}\text { Centro de } \\
\text { Convenções }\end{array}$ & Moderno centro de convenções para até 1,2 mil pessoas \\
\hline Vestiários & 04 vestiários \\
\hline Elevadores & 15 elevadores \\
\hline Escadas & Arena possui 26 escadas rolantes \\
\hline Camarotes & $\begin{array}{l}166 \text { camarotes, no 3o e } 40 \text { pavimentos, sendo que a capacidade } \\
\text { varia de } 12,17,18 \text { e } 21 \text { lugares, dependendo da sua localização. }\end{array}$ \\
\hline $\begin{array}{l}\text { CATERING } \\
\text { Serviço de } \\
\text { alimentacão }\end{array}$ & $\begin{array}{l}\text { São mais de } 20 \text { lanchonetes, uma cozinha central de } 1300 \text { m2 e } \\
\text { cozinha salelites distribuidas pela arena nas caixas de escadas. }\end{array}$ \\
\hline Banheiros & $\begin{array}{l}\text { O Allianz Parque dispõe de } 63 \text { sanitários preparados para } \\
\text { portadores de necessidades especiais. Há banheiros disponiveis } \\
\text { em todos os andares da arena. }\end{array}$ \\
\hline Inauguração & $19 / 11 / 2014$ \\
\hline $\begin{array}{l}\text { Dados da } \\
\text { Construção }\end{array}$ & $\begin{array}{l}\text { Data da Construção: 05/10/2010 a 19/11/2014 } \\
\text { Nome: Allianz Parque } \\
\text { Local: Avenida Francisco Matarazzo, } 1705 \text { - Água Branca, SP } \\
\text { Propriedade: Privada } \\
\text { Proprietário: S. E. Palmeiras } \\
\text { Administrador: WTorre Properties/Arenas AEG (Gestão) } \\
\text { Arquiteto: Edo Rocha Arquiteturas } \\
\text { Mandante: S.E. Palmeiras } \\
\text { Custo: R\$ } 650 \text { milhões }\end{array}$ \\
\hline Partida inaugural & $\begin{array}{l}\text { Palmeiras } 0 \times 2 \text { Sport } \\
\text { Primeiro gol: Ananias (Sport) }\end{array}$ \\
\hline
\end{tabular}

Fonte: Sociedade Esportiva Palmeiras www.palmeiras.com.br , www.wtorre.com.br acesso em 11/04/2018.

O Allianz Parque alcançou um número expressivo nas redes sociais. A casa do Palmeiras chegou a 1 milhão de seguidores em todas as suas plataformas (Top 
5 mundial), sendo a primeira arena do país a atingir essa marca. Somente no Facebook, o Allianz tem mais de 700 mil seguidores - são mais de 200 mil no Instagram e 100 mil no Twitter.

Os números colocam o Allianz Parque entre os cinco estádios mais populares do mundo nas redes sociais. A casa do Palmeiras tem, por exemplo, mais seguidores do que outras arenas mundialmente conhecidas, como Stamford Bridge, arena do líder do campeonato inglês Chelsea, e do estádio do Barcelona, o Camp Nou. Em comparação com outros estádios do país, o Allianz Parque já coloca uma grande vantagem. A arena alviverde supera em 250 mil seguidores a Arena Corinthians e em quase $\mathbf{5 0 0}$ mil usuários a arena Itaipava Fonte Nova.

Evidente que número de seguidores não significa engajamento e é justamente este segundo que faz toda a diferença nas redes sociais. Mas também nesse aspecto a arena tem se mostrado atenta, com direito a publicações que envolvem fotos e vídeos especiais, promoções e conteúdos exclusivos.

Veja, abaixo, ranking das arenas nas redes sociais. No levantamento foi considerada a quantidade de seguidores das arenas no Facebook, Instagram e Twitter.

Tabela 23 - Seguidores do Allianz Parque nas redes sociais

TOP 5 arenas nacionais em número de seguidores nas redes sociais:

\begin{tabular}{|c|l|c|}
\hline $\mathbf{1}$ & Allianz Parque & 1 milhão \\
\hline $\mathbf{2}$ & Arena Corinthians & $746 \mathrm{mil}$ \\
\hline $\mathbf{3}$ & Itaipava Fonte Nova & $504 \mathrm{mil}$ \\
\hline $\mathbf{4}$ & Arena Castelão & $301 \mathrm{mil}$ \\
\hline $\mathbf{5}$ & Arena do Grêmio & $225 \mathrm{mil}$ \\
\hline
\end{tabular}

Fonte: https://exame.abril.com.br/blog/esporte-executivo/ acesso em 10/02/2020

O campo do Parque da Antarctica existe desde 1902, anterior até mesmo à fundação do então Palestra Italia, ocorrida em 1914. As primeiras arquibancadas foram construídas no início dos anos 30. O Jardim Suspenso é dos anos 60, e foi com essa face que o estádio permaneceu até o ano de 2010. No Allianz Parque o 
novo e moderno estádio levou quatro anos para ficar pronto. Foi inaugurado no dia 19 de novembro de 2014.

O clube social também foi remodelado, recebendo obras compensatórias por conta dos espaços suprimidos com a construção. Alcançando o conceito de arena multiuso, a nova casa do Palmeiras recebe mega-shows, espetáculos e jogos de futebol com até 40.000 pessoas, além de shows menores e outros eventos sociais.

\section{Figura 08 - Antes e depois: Estádio Parte Externa}

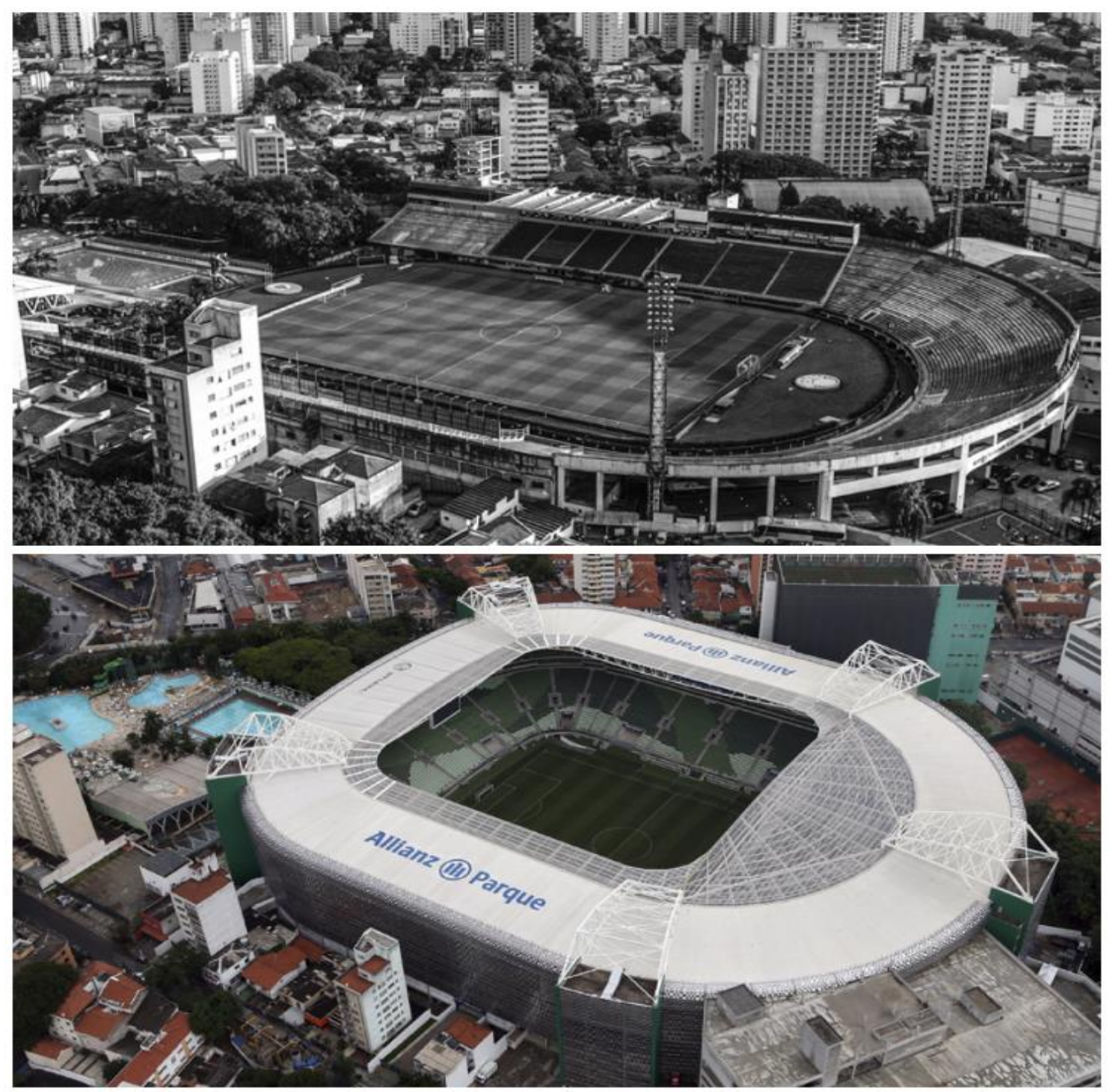

Fonte:Jornal Estadão:Allianz Parque-www.estadao.com.br - acesso em14/04/2018 
No Palestra Italia a comparação da visão atrás do 'gol da ferradura' impressiona e mostra a grande diferença de um estádio antigo para um novo. $\mathrm{O}$ Allianz Parque possui espaço para um palco e estrutura para receber grandes shows, além de eventos corporativos. No alto, atrás de cada gol há um telão de $103 \mathrm{~m} 2$ cada (figura 8 ).

Figura 09 - Antes e depois: Estádio Parte Interna
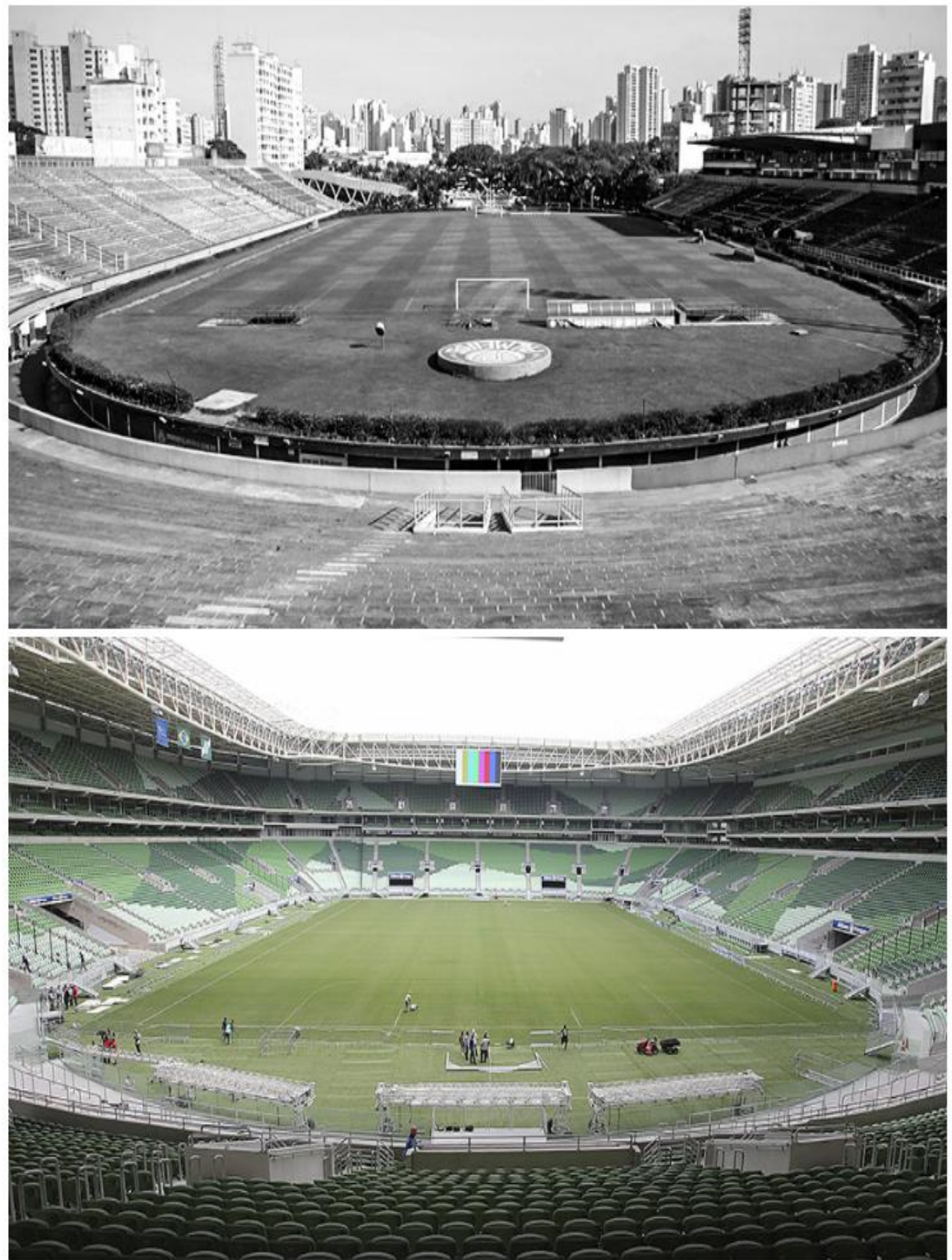

Fonte:Jornal Estadão:Allianz Parque-www.estadao.com.br - acesso em14/04/2018 
A reforma no Palestra Italia diminuiu o espaço que havia entre o gramado e a arquibancada. O símbolo do Palmeiras foi retirado. Já no Allianz Parque a arquibancada de concreto deu lugar a setores mais bem definidos e as cadeiras ganharam tonalidades de verde (figura 9).

Figura 10 - Antes e depois: Gramado e arquibancada
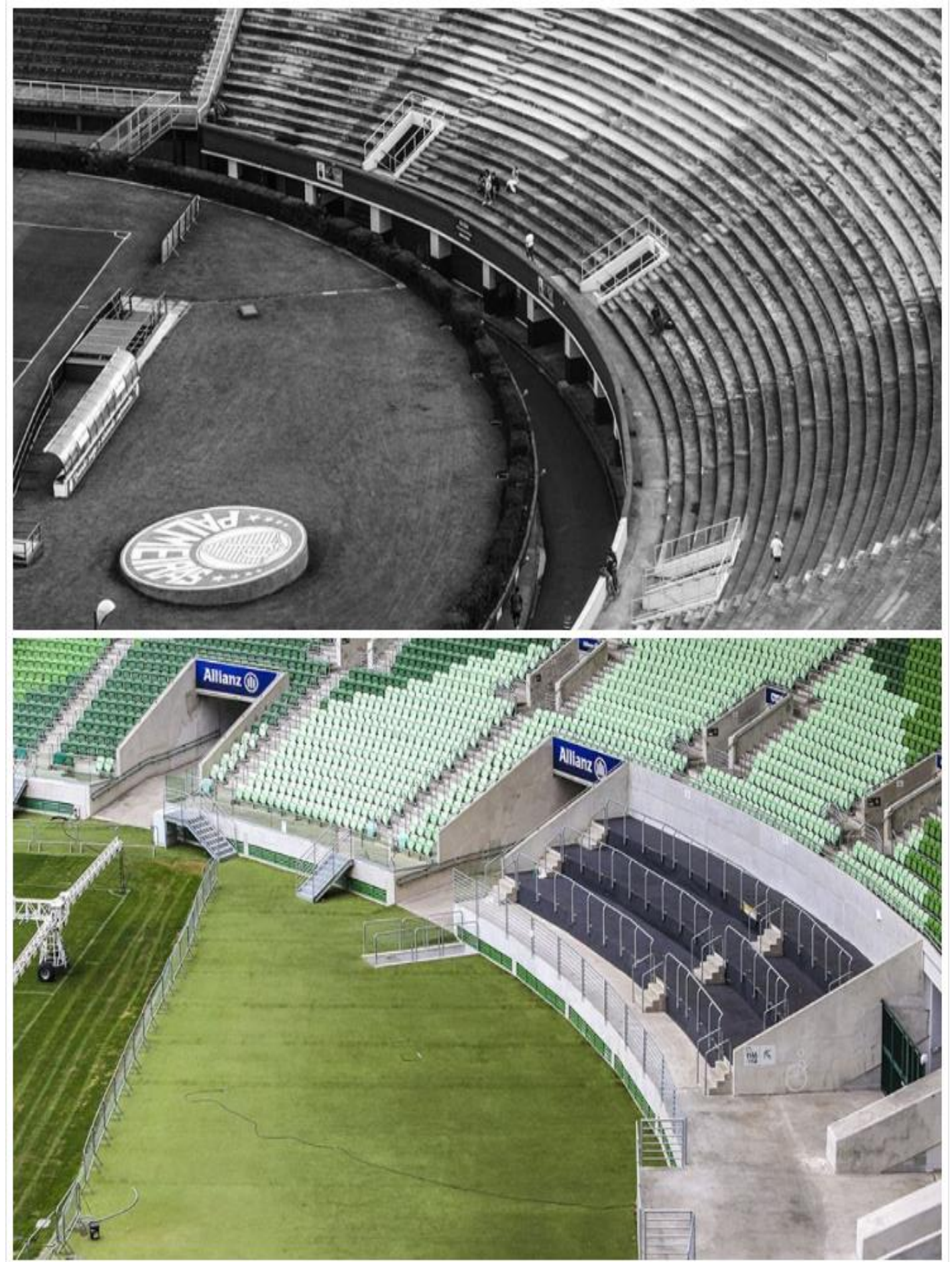

Fonte:Jornal Estadão:Allianz Parque-www.estadao.com.br - acesso em14/04/2018. 
Dos 32 mil lugares do antigo Palestra poucos havia assentos, e eram todos marcados (5 mil). No Allianz Parque só existem cadeiras retráteis. E elas estão em todos os setores, até mesmo onde ficam as torcidas organizadas (figura 10).

\section{Figura 11 - Antes e depois: Cadeiras}

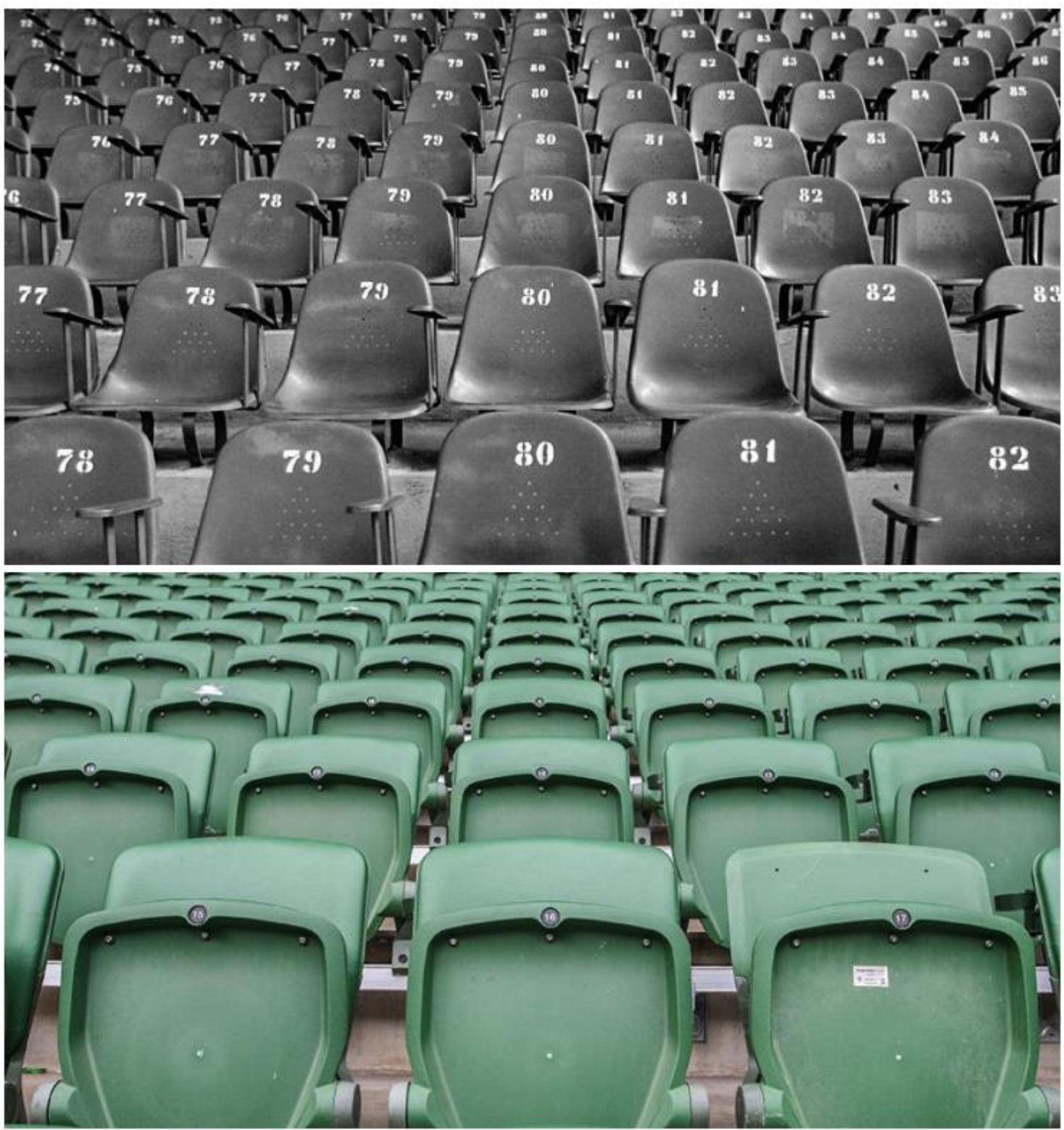

Fonte:Jornal Estadão:Allianz Parque-www.estadao.com.br - acesso em14/04/2018

Das janelas e coberturas dos prédios da Pompeia, bairro onde fica o estádio Palestra Italia, torcedores podiam se dar ao luxo de assistir as partidas de fora do estádio. Tal privilégio perpetuado por décadas acabou. Com a construção do Allianz Parque o estádio ganhou uma cobertura que impede a visão dos moradres dos prédios em volta. Os camarotes se multiplicaram. Se no antigo Palestra eram 
apenas 15, em condições precárias, com cadeiras desconfortáveis, no Allianz esse número chega a 188 (figura 11).

Figura 12 - Antes e depois: Campo
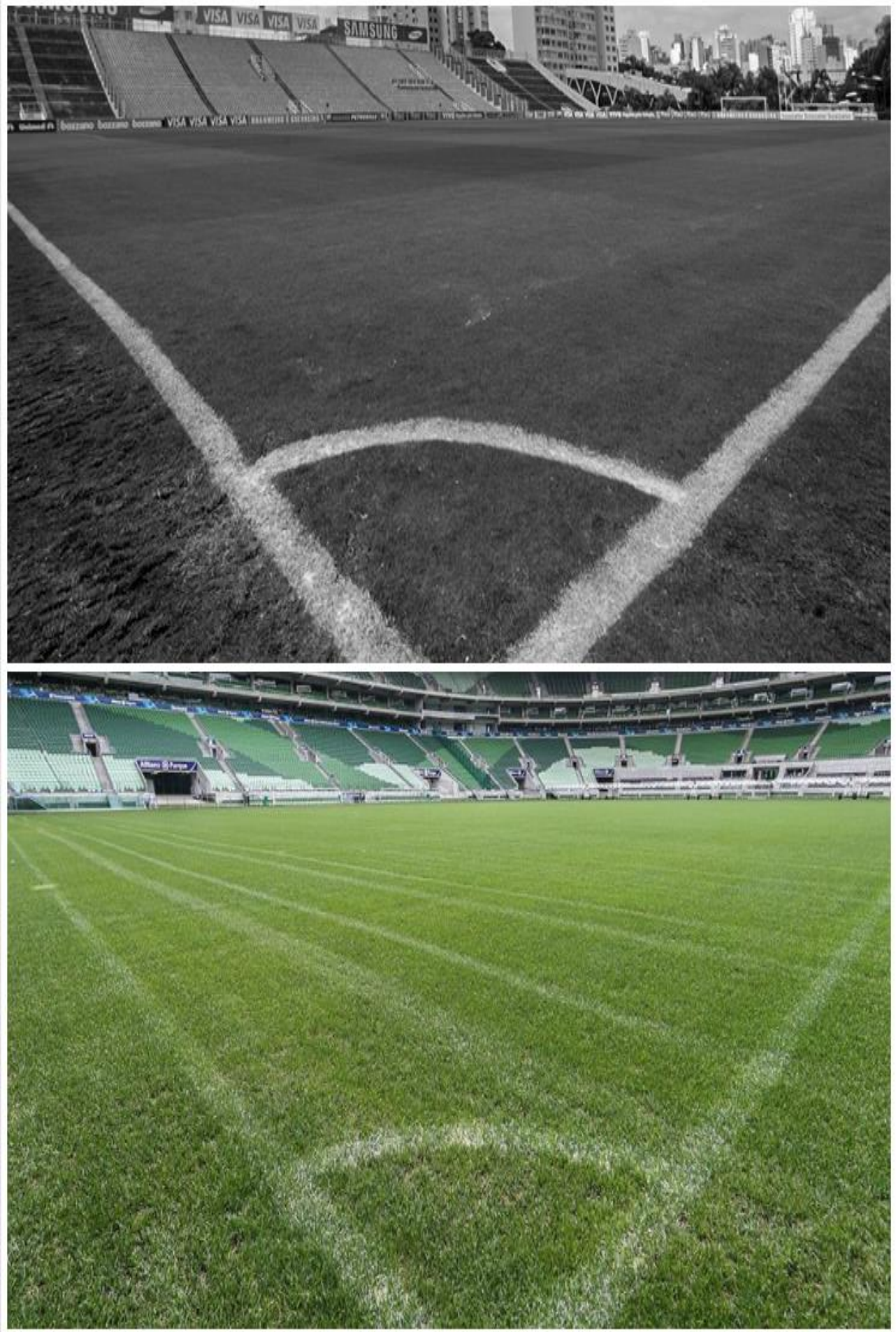

Fonte:Jornal Estadão:Allianz Parque-www.estadao.com.br - acesso em14/04/2018 


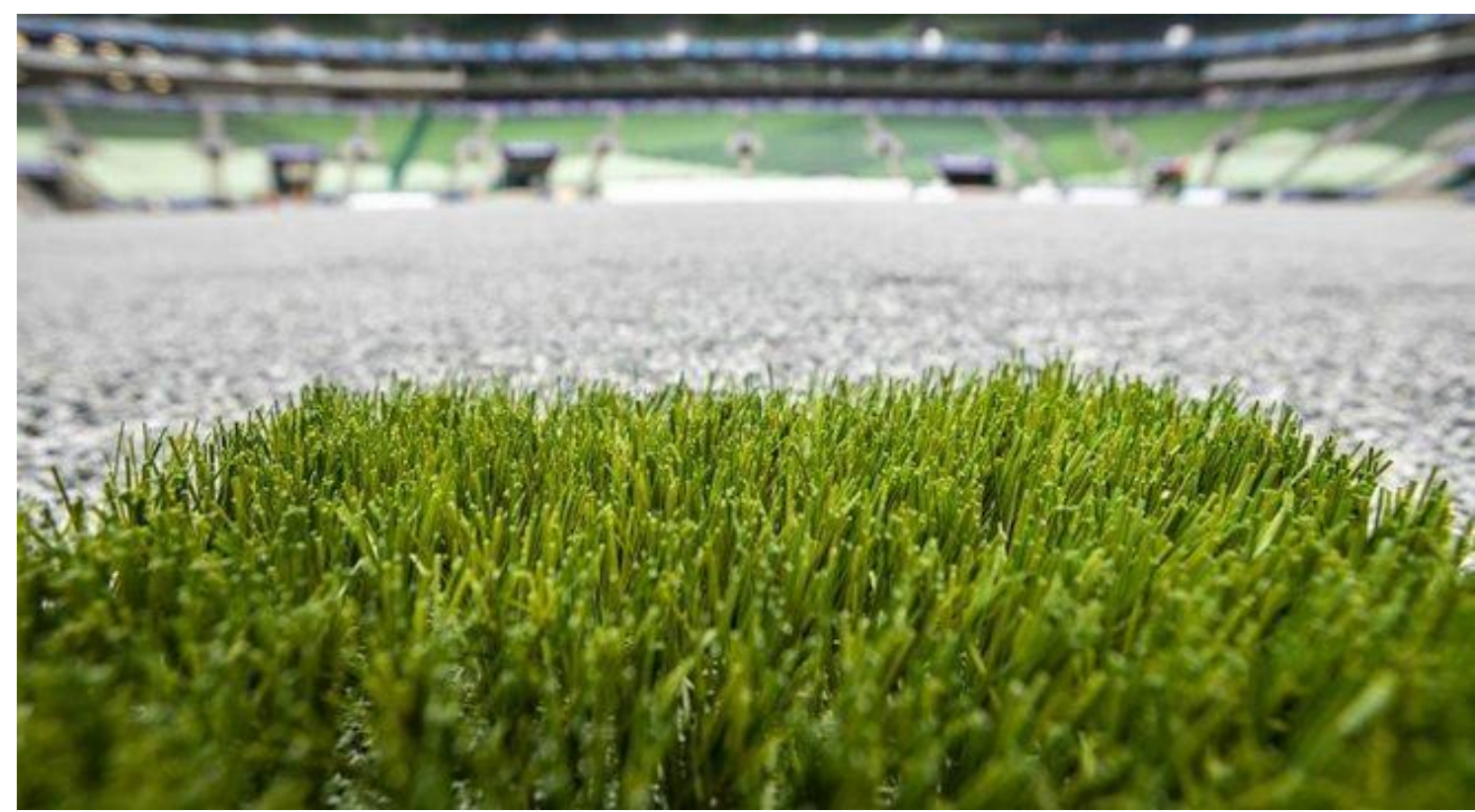

Fonte: https://esportes.r7.com/futebol/grama-sintetica acesso em 10/02/2020

Importante destacar também que a Sociedade Esportiva Palmeiras, a partir da inauguração do estádio, tornou-se referência com seu programa de sócio torcedor, denominado Sócio Avanti87. Iniciado em 2009, o Programa tinha poucos inscritos com o estádio Palestra Italia, avançou um tanto passando de 28.164 sóciostorcedores em 2013, para 80.500 sócios-torcedores em 2014, nos anos de construção do estádio novo, quando o Palmeiras mandava seus jogos no Pacaembu, e cresceu exponencialmente com a inauguração do Allianz Parque. Houve uma queda brusca no número de Sócio Avanti em 2019, conforme tabelas abaixo:

${ }^{87}$ Avanti Palmeiras é o programa de sócio torcedor da Sociedade Esportiva Palmeiras. 
Tabela 24 - Ranking Sócio-torcedor 2013

\begin{tabular}{|c|c|c|}
\hline Ranking 2013 & Clubes & N$^{\circ}$ de sócio-torcedores \\
\hline $1^{\circ}$ & Flamengo & 58.622 \\
\hline $2^{\circ}$ & Cruzeiro & 45.743 \\
\hline $3^{\circ}$ & Internacional & 32.069 \\
\hline $4^{\circ}$ & Palmeiras & $\mathbf{2 8 . 1 6 4}$ \\
\hline $5^{\circ}$ & Atlético-MG & 22.067 \\
\hline $6^{\circ}$ & Bahia & 16.196 \\
\hline $7^{\circ}$ & São Paulo & 14.578 \\
\hline $8^{\circ}$ & Sport & 13.029 \\
\hline $9^{\circ}$ & Fluminense & 9.715 \\
\hline $10^{\circ}$ & Grêmio & 8.219 \\
\hline
\end{tabular}

Fonte: Jornal Estadão - www.estadao.com.br - acesso em 18/04/2018

Tabela 25 - Ranking Sócio-torcedor 2014

\begin{tabular}{|c|c|c|}
\hline Ranking & Clubes & $\mathbf{N}^{\circ}$ de sócio-torcedores \\
\hline $1^{\circ}$ & Internacional & 129.396 \\
\hline $2^{\circ}$ & Palmeiras & $\mathbf{8 0 . 5 0 0}$ \\
\hline $3^{\circ}$ & Grêmio & 80.484 \\
\hline $4^{\circ}$ & Corinthians & 72.332 \\
\hline $5^{\circ}$ & Cruzeiro & 67.289 \\
\hline $6^{\circ}$ & Santos & 56.973 \\
\hline $7^{\circ}$ & Flamengo & 53.658 \\
\hline $8^{\circ}$ & São Paulo & 43.257 \\
\hline $9^{\circ}$ & Atlético-MG & 36.996 \\
\hline $10^{\circ}$ & Bahia & 24.021 \\
\hline
\end{tabular}

Fonte: IG São Paulo Esportes - www.esporte.ig.com.br - acesso em 18/04/2018 
A partir de 2015 o programa sócio-torcedor AVANTI recebe um vultuoso incremento de mais de $50 \%$, indo de 80.500 para 126.903 :

Tabela 26 - Ranking Sócio-torcedor 2015

\begin{tabular}{|c|c|c|}
\hline Ranking 2015 & Clubes & $\mathbf{N}^{\circ}$ de sócio-torcedores \\
\hline $1^{\circ}$ - & Corinthians & 135.166 \\
\hline $\mathbf{2}^{\circ}$ & Palmeiras & $\mathbf{1 2 6 . 9 0 3}$ \\
\hline $3^{\circ}$ & Internacional & 112.756 \\
\hline $4^{\circ}$ & Grêmio & 88.714 \\
\hline $5^{\circ}$ & São Paulo & 80.388 \\
\hline $6^{\circ}$ & Cruzeiro & 73.028 \\
\hline $7^{\circ}$ & Flamengo & 64.929 \\
\hline $8^{\circ}$ & Santos & 61.759 \\
\hline $9^{\circ}$ & Atlético-MG & 48.025 \\
\hline $10^{\circ}$ & Sport & 41.829 \\
\hline
\end{tabular}

Fonte: http://globoesporte.globo.com acesso em 18/04/2018

Tabela 27 - Ranking Sócio-torcedor 2016

\begin{tabular}{|c|c|c|}
\hline Ranking 2016 & Clubes & $\mathbf{N}^{\circ}$ de sócio-torcedores \\
\hline $1^{\circ}$ & Corinthians & 128.181 \\
\hline $2^{\circ}$ & Palmeiras & $\mathbf{1 2 6 . 6 0 7}$ \\
\hline $3^{\circ}$ & Internacional & 112.756 \\
\hline $4^{\circ}$ & São Paulo & 109.070 \\
\hline $5^{\circ}$ & Grêmio & 95.233 \\
\hline $6^{\circ}$ & Cruzeiro & 76.068 \\
\hline $7^{\circ}$ & Santos & 63.983 \\
\hline $8^{\circ}$ & Atlético-MG & 63.375 \\
\hline $9^{\circ}$ & Flamengo & 52.843 \\
\hline $10^{\circ}$ & Sport & 43.749 \\
\hline
\end{tabular}

Fonte: Exame - Negócios, economia, tecnologia e carreira - https://exame.abril.com.br acesso em 18/04/2018. 
Tabela 28 - Ranking Sócio-torcedor 2017

\begin{tabular}{|c|c|c|}
\hline Ranking 2017 & Clubes & $\mathbf{N}^{\circ}$ de sócio-torcedores \\
\hline $1^{\circ}$ & Corinthians & 123.106 \\
\hline $\mathbf{2}^{\mathbf{o}}$ & Palmeiras & $\mathbf{1 2 2 . 7 7 8}$ \\
\hline $3^{\circ}$ & Grêmio & 120.944 \\
\hline $4^{\circ}$ & São Paulo & 115.741 \\
\hline $5^{\circ}$ & Internacional & 112.756 \\
\hline $6^{\circ}$ & Flamengo & 103.708 \\
\hline $7^{\circ}$ & Atlético-MG & 97.665 \\
\hline $8^{\circ}$ & Cruzeiro & 54.777 \\
\hline $9^{\circ}$ & Sport & 43.990 \\
\hline $10^{\circ}$ & Fluminense & 35.889 \\
\hline
\end{tabular}

Fonte: ESPN -www.espn.com.br -acesso em 18/04/2018

Tabela 29 - Ranking Sócio-torcedor 2018

\begin{tabular}{|c|c|c|}
\hline Ranking 2018 & Clubes & $\mathrm{N}^{\circ}$ de sócio-torcedores \\
\hline $1^{\circ} \underline{0}$ & Grêmio & 140.979 \\
\hline $2^{0}$ & Corinthians & 126.001 \\
\hline 30 & Palmeiras & 123.924 \\
\hline $4^{\circ}$ & São Paulo & 120.044 \\
\hline $5^{0}$ & Internacional & 112.756 \\
\hline $6^{\circ}$ & Atlético-MG & 108.738 \\
\hline $7^{0}$ & Cruzeiro & 78.087 \\
\hline $8^{0}$ & Flamengo & 56.842 \\
\hline $9^{\circ}$ & Sport & 41.993 \\
\hline $10^{\circ}$ & Fluminense & 37.095 \\
\hline
\end{tabular}

Fonte: Futebol Melhor - Torcedômetro https://www.futebolmelhor.com.br - acesso em $18 / 04 / 2018$

Tabela 30 - Ranking Sócio-torcedor 2019

\begin{tabular}{|c|c|c|}
\hline Ranking 2019 & Clubes & $\mathbf{N}^{\circ}$ de sócio-torcedores \\
\hline $1^{\circ}$ & Vasco da Gama & 183.000 \\
\hline $2^{0}$ & Flamengo & 131.000 \\
\hline $3^{0}$ & Internacional & 126.000 \\
\hline $4^{0}$ & Atlético Mineiro & 110.000 \\
\hline $5^{0}$ & Grêmio & 91.000 \\
\hline $6^{0}$ & Corinthians & 81.000 \\
\hline $7^{0}$ & Palmeiras & 60.000 \\
\hline $8^{0}$ & Bahia & 44.000 \\
\hline $9^{0}$ & Sport & 38.000 \\
\hline $10^{\circ}$ & Fortaleza & 31.000 \\
\hline
\end{tabular}

Fonte: https://mundotop10.com acesso em 10/02/2020 
O Allianz Parque converteu-se, literalmente, na casa do torcedor palmeirense.

A cidade de São Paulo possui 96 distritos administrativos. Em 95 deles, não há supremacia de torcedores palmeirenses sobre corintianos e são-paulinos; apenas em um, o distrito da Lapa, sucede-se tal fenômeno, conforme a pesquisa do Datafolha DNA Paulistano registrada abaixo:

Tabela 31 - Torcedor: Datafolha 2008 (em percentual)

\begin{tabular}{|l|c|c|c|c|}
\hline \multicolumn{5}{|c|}{ I - ZONA NORTE - (8 Distritos) } \\
\hline \multicolumn{1}{|c|}{ Distrito } & Corinthians & São Paulo & Palmeiras & Outros/Nenhum \\
\hline Jaçanã & $42 \%$ & $18 \%$ & $10 \%$ & $30 \%$ \\
\hline Mandaqui & $37 \%$ & $23 \%$ & $23 \%$ & $27 \%$ \\
\hline Santana & $34 \%$ & $23 \%$ & $13 \%$ & $30 \%$ \\
\hline Tremembé & $35 \%$ & $21 \%$ & $14 \%$ & $30 \%$ \\
\hline Tucuruvi & $36 \%$ & $23 \%$ & $12 \%$ & $29 \%$ \\
\hline Vila Guilherme & $39 \%$ & $20 \%$ & $14 \%$ & $27 \%$ \\
\hline Vila Maria & $40 \%$ & $15 \%$ & $11 \%$ & $34 \%$ \\
\hline Vila Medeiros & $38 \%$ & $25 \%$ & $12 \%$ & $25 \%$ \\
\hline
\end{tabular}

\begin{tabular}{|l|c|c|c|c|}
\hline \multicolumn{5}{|c|}{ II - ZONA SUL - (8 Distritos) } \\
\hline \multicolumn{1}{|c|}{ Distrito } & Corinthians & São Paulo & Palmeiras & Outros/Nenhum \\
\hline Campo Belo & $21 \%$ & $27 \%$ & $17 \%$ & $35 \%$ \\
\hline Cursino & $31 \%$ & $22 \%$ & $20 \%$ & $27 \%$ \\
\hline Ipiranga & $38 \%$ & $20 \%$ & $13 \%$ & $29 \%$ \\
\hline Jabaquara & $36 \%$ & $25 \%$ & $15 \%$ & $24 \%$ \\
\hline Moema & $25 \%$ & $28 \%$ & $17 \%$ & $30 \%$ \\
\hline Sacomã & $33 \%$ & $22 \%$ & $15 \%$ & $30 \%$ \\
\hline Saúde & $28 \%$ & $23 \%$ & $15 \%$ & $34 \%$ \\
\hline Vila Mariana & $26 \%$ & $24 \%$ & $17 \%$ & $33 \%$ \\
\hline
\end{tabular}




\begin{tabular}{|l|c|c|c|c|}
\hline \multicolumn{5}{|c|}{ III - ZONA CENTRO - (10 Distritos) } \\
\hline \multicolumn{1}{|c|}{ Distrito } & Corinthians & São Paulo & Palmeiras & Outros/Nenhum \\
\hline Bela Vista & $26 \%$ & $27 \%$ & $15 \%$ & $32 \%$ \\
\hline Bom Retiro & $34 \%$ & $18 \%$ & $14 \%$ & $34 \%$ \\
\hline Brás & $36 \%$ & $16 \%$ & $18 \%$ & $30 \%$ \\
\hline Cambuci & $35 \%$ & $20 \%$ & $15 \%$ & $30 \%$ \\
\hline Consolação & $24 \%$ & $26 \%$ & $16 \%$ & $34 \%$ \\
\hline Liberdade & $26 \%$ & $18 \%$ & $19 \%$ & $37 \%$ \\
\hline Pari & $40 \%$ & $14 \%$ & $15 \%$ & $31 \%$ \\
\hline República & $29 \%$ & $19 \%$ & $15 \%$ & $37 \%$ \\
\hline Santa Cecília & $27 \%$ & $24 \%$ & $17 \%$ & $32 \%$ \\
\hline Sé & $30 \%$ & $23 \%$ & $13 \%$ & $34 \%$ \\
\hline
\end{tabular}

\begin{tabular}{|l|c|c|c|c|}
\hline \multicolumn{5}{|c|}{ V - ZONA OESTE - (15 Distritos) } \\
\hline \multicolumn{1}{|c|}{ Distrito } & Corinthians & São Paulo & Palmeiras & Outros/Nenhum \\
\hline Alto de Pinheiros & $28 \%$ & $30 \%$ & $17 \%$ & $25 \%$ \\
\hline Barra Funda & $25 \%$ & $28 \%$ & $24 \%$ & $23 \%$ \\
\hline Butantã & $31 \%$ & $26 \%$ & $16 \%$ & $27 \%$ \\
\hline Itaim Bibi & $25 \%$ & $22 \%$ & $14 \%$ & $39 \%$ \\
\hline Jaguara & $36 \%$ & $22 \%$ & $19 \%$ & $23 \%$ \\
\hline Jaguaré & $33 \%$ & $19 \%$ & $15 \%$ & $33 \%$ \\
\hline Jardim Paulista & $23 \%$ & $26 \%$ & $16 \%$ & $35 \%$ \\
\hline Lapa & $\mathbf{2 4 \%}$ & $\mathbf{2 1 \%}$ & $\mathbf{2 9} \%$ & $\mathbf{2 6 \%}$ \\
\hline Morumbi & $31 \%$ & $32 \%$ & $13 \%$ & $24 \%$ \\
\hline Perdizes & $\mathbf{2 0 \%}$ & $\mathbf{2 5 \%}$ & $\mathbf{2 3} \%$ & $\mathbf{3 2 \%}$ \\
\hline Pinheiros & $22 \%$ & $31 \%$ & $16 \%$ & $31 \%$ \\
\hline Raposo Tavares & $29 \%$ & $25 \%$ & $13 \%$ & $33 \%$ \\
\hline Rio Pequeno & $31 \%$ & $25 \%$ & $13 \%$ & $31 \%$ \\
\hline Vila Leopoldina & $25 \%$ & $21 \%$ & $18 \%$ & $36 \%$ \\
\hline Vila Sônia & $28 \%$ & $31 \%$ & $14 \%$ & $27 \%$ \\
\hline
\end{tabular}




\begin{tabular}{|l|c|c|c|c|}
\hline \multicolumn{5}{|c|}{ IV - EXTREMO LESTE - (16 Distritos) } \\
\hline \multicolumn{1}{|c|}{ Distrito } & Corinthians & $\begin{array}{c}\text { São } \\
\text { Paulo }\end{array}$ & Palmeiras & Outros/Nenhum \\
\hline Cidade Líder & $34 \%$ & $18 \%$ & $16 \%$ & $32 \%$ \\
\hline Cidade Tiradentes & $38 \%$ & $23 \%$ & $12 \%$ & $27 \%$ \\
\hline Ermelino Matarazzo & $36 \%$ & $18 \%$ & $12 \%$ & $34 \%$ \\
\hline Guaianases & $40 \%$ & $23 \%$ & $9 \%$ & $28 \%$ \\
\hline Iguatemi & $30 \%$ & $23 \%$ & $13 \%$ & $34 \%$ \\
\hline Itaim Paulista & $34 \%$ & $22 \%$ & $11 \%$ & $33 \%$ \\
\hline Itaquera & $41 \%$ & $19 \%$ & $10 \%$ & $30 \%$ \\
\hline Jardim Helena & $36 \%$ & $19 \%$ & $11 \%$ & $34 \%$ \\
\hline José Bonifácio & $40 \%$ & $22 \%$ & $14 \%$ & $24 \%$ \\
\hline Lajeado & $32 \%$ & $23 \%$ & $12 \%$ & $33 \%$ \\
\hline Parque do Carmo & $40 \%$ & $22 \%$ & $8 \%$ & $30 \%$ \\
\hline São Mateus & $40 \%$ & $21 \%$ & $14 \%$ & $25 \%$ \\
\hline São Miguel Paulista & $36 \%$ & $19 \%$ & $11 \%$ & $34 \%$ \\
\hline São Rafael & $37 \%$ & $18 \%$ & $9 \%$ & $36 \%$ \\
\hline Vila Curuçá & $37 \%$ & $19 \%$ & $9 \%$ & $35 \%$ \\
\hline Vila Jacuí & $33 \%$ & $21 \%$ & $16 \%$ & $30 \%$ \\
\hline
\end{tabular}

\begin{tabular}{|l|c|c|c|c|}
\hline \multicolumn{5}{|c|}{ VI - EXTREMO SUL - (14 Distritos) } \\
\hline \multicolumn{1}{|c|}{ Distrito } & Corinthians & São Paulo & Palmeiras & Outros/Nenhum \\
\hline Campo Grande & $31 \%$ & $26 \%$ & $14 \%$ & $29 \%$ \\
\hline Campo Limpo & $29 \%$ & $24 \%$ & $15 \%$ & $32 \%$ \\
\hline Capão Redondo & $28 \%$ & $28 \%$ & $12 \%$ & $32 \%$ \\
\hline Cidade Ademar & $33 \%$ & $25 \%$ & $15 \%$ & $27 \%$ \\
\hline Cidade Dutra & $30 \%$ & $19 \%$ & $16 \%$ & $35 \%$ \\
\hline Grajaú & $29 \%$ & $26 \%$ & $14 \%$ & $31 \%$ \\
\hline Jardim Ângela & $26 \%$ & $25 \%$ & $13 \%$ & $36 \%$ \\
\hline Jardim São Luís & $29 \%$ & $26 \%$ & $14 \%$ & $31 \%$ \\
\hline Marsilac & $24 \%$ & $29 \%$ & $15 \%$ & $32 \%$ \\
\hline Parelheiros & $22 \%$ & $27 \%$ & $13 \%$ & $38 \%$ \\
\hline Pedreira & $34 \%$ & $26 \%$ & $12 \%$ & $28 \%$ \\
\hline Santo Amaro & $25 \%$ & $27 \%$ & $21 \%$ & $27 \%$ \\
\hline Socorro & $28 \%$ & $25 \%$ & $16 \%$ & $31 \%$ \\
\hline Vila Andrade & $24 \%$ & $33 \%$ & $14 \%$ & $29 \%$ \\
\hline
\end{tabular}




\begin{tabular}{|l|c|c|c|c|}
\hline \multicolumn{5}{|c|}{ VII - ZONA NOROESTE - (10 Distritos) } \\
\hline \multicolumn{1}{|c|}{ Distrito } & Corinthians & São Paulo & Palmeiras & Outros/Nenhum \\
\hline Anhangüera & $27 \%$ & $23 \%$ & $13 \%$ & $37 \%$ \\
\hline Brasilândia & $32 \%$ & $23 \%$ & $14 \%$ & $31 \%$ \\
\hline Cachoeirinha & $35 \%$ & $21 \%$ & $10 \%$ & $34 \%$ \\
\hline Casa Verde & $43 \%$ & $22 \%$ & $13 \%$ & $22 \%$ \\
\hline Freguesia do Ó & $39 \%$ & $23 \%$ & $15 \%$ & $23 \%$ \\
\hline Jaraguá & $37 \%$ & $19 \%$ & $12 \%$ & $32 \%$ \\
\hline Limão & $43 \%$ & $19 \%$ & $15 \%$ & $23 \%$ \\
\hline Perus & $38 \%$ & $16 \%$ & $14 \%$ & $32 \%$ \\
\hline Pirituba & $26 \%$ & $17 \%$ & $21 \%$ & $36 \%$ \\
\hline São Domingos & $39 \%$ & $20 \%$ & $14 \%$ & $27 \%$ \\
\hline
\end{tabular}

\begin{tabular}{|l|c|c|c|c|}
\hline \multicolumn{5}{|c|}{ VIII - ZONA LESTE - (15 Distritos) } \\
\hline \multicolumn{1}{|c|}{ Distrito } & Corinthians & São Paulo & Palmeiras & Outros/Nenhum \\
\hline Água Rasa & $38 \%$ & $21 \%$ & $16 \%$ & $25 \%$ \\
\hline Aricanduva & $38 \%$ & $20 \%$ & $13 \%$ & $29 \%$ \\
\hline Artur Alvim & $36 \%$ & $17 \%$ & $13 \%$ & $34 \%$ \\
\hline Belém & $35 \%$ & $15 \%$ & $20 \%$ & $30 \%$ \\
\hline Cangaíba & $35 \%$ & $18 \%$ & $12 \%$ & $35 \%$ \\
\hline Carrão & $43 \%$ & $18 \%$ & $15 \%$ & $24 \%$ \\
\hline Mooca & $32 \%$ & $18 \%$ & $23 \%$ & $27 \%$ \\
\hline Penha & $35 \%$ & $22 \%$ & $15 \%$ & $28 \%$ \\
\hline Ponte Rasa & $41 \%$ & $19 \%$ & $10 \%$ & $30 \%$ \\
\hline São Lucas & $37 \%$ & $20 \%$ & $12 \%$ & $31 \%$ \\
\hline Sapopemba & $37 \%$ & $22 \%$ & $17 \%$ & $24 \%$ \\
\hline Tatuapé & $39 \%$ & $19 \%$ & $18 \%$ & $24 \%$ \\
\hline Vila Formosa & $40 \%$ & $20 \%$ & $15 \%$ & $25 \%$ \\
\hline Vila Matilde & $39 \%$ & $20 \%$ & $14 \%$ & $27 \%$ \\
\hline Vila Prudente & $34 \%$ & $14 \%$ & $18 \%$ & $34 \%$ \\
\hline
\end{tabular}

Fonte:DataFolha-Pesquisa de torcida 2008-www.folhauol.com.br-acesso em 18/04/2018

A Companhia Matarazzo é a origem dessa concentração de torcedores, ao investir na construção de casas para ter seus funcionários ao lado da fábrica, situada em frente ao então Parque da Antarctica, de propriedade da cervejaria, terreno que veio abrigar o estádio Palestra Italia, e a seguir o Allianz Parque. Como a grande maioria dos funcionários eram italianos ou descendentes, concentrou-se ali um expressivo número daqueles que vieram a se tornar os fundadores e torcedores da Società Sportiva Palestra Italia, antecessora da Sociedade Esportiva Palmeiras. Grande parte dos fundadores do Palestra Italia eram funcionários do grupo Matarazzo. 
Em "Imigração e Futebol, O Caso Palestra Italia", José Renato de Campos Araújo registra: "Os formuladores da ideia que gerou o Palestra Italia eram funcionários administrativos das empresas Matarazzo, cujo objetivo era aglutinar em torno de uma associação desportiva, justamente a parte italiana dessa faixa social, que não encontrava espaço nas associações futebolísiticas de porte da cidade". . A região foi se espraiando: Vila Romana, Lapa, Perdizes e arredores foram sendo ocupados por italianos imigrantes e descendentes.

O Allianz Parque tem à sua volta a maior densidade de torcedores palmeirenses da cidade, criando o clima de "estar em casa" aos torcedores que ali habitam. Até hoje, em que pese a gentrificação ocorrida pela construção do estádio, observa-se uma massa de torcedores que descem dos prédios em volta ao estádio, quase todos com a camisa do clube, caminhando para presenciar as partidas de futebol do Palmeiras. A localização é fator relevante para a frequência e podemos registrá-la não só com o dado mencionado da maioria inusual de torcedores palmeirenses com relação aos maiores rivais na cidade, como pela utilização do Allianz Parque comparado ao Pacaembu, que não fica distante, e é estádio tradicional da cidade e bastante querido por todas as torcidas, situado na mesma zona oeste, servido por metrô e por fartas linhas de ônibus e que nunca logrou seduzir o torcedor com a mesma intensidade.

A localização conta muito na frequência dos estádios e a simbiose entre todos os fatores citados, inclusive a tal proximidade física, tornaram o modelo de ocupação do estádio mais eficaz. 
Tabela 32 - Comparação dos estádios: Allianz Parque X Pacaembu

\begin{tabular}{|c|c|c|}
\hline ESTÁDIO & Allianz Parque & Pacaembu \\
\hline Nome & Allianz Parque & $\begin{array}{c}\text { Estádio Municipal Paulo Machado } \\
\text { de Carvalho }\end{array}$ \\
\hline Construção & 05/10/2010 a 19/11/2014 & 17/09/1938 a 1940 \\
\hline Inauguração & $19 / 11 / 2014$ & $27 / 04 / 1940$ \\
\hline Local & $\begin{array}{c}\text { Avenida Francisco Matarazzo, } 1705 \text { - } \\
\text { Agua Branca, SP }\end{array}$ & $\begin{array}{c}\text { Praça Charles Miller - Pacaembu, } \\
\text { SP }\end{array}$ \\
\hline Capacidade & 43.713 & 40.199 \\
\hline $\begin{array}{l}\text { Taxa de } \\
\text { Ocupação }\end{array}$ & $\begin{array}{l}\text { Em } 2019 \text { foi de aproximadamente } \\
699 \%\end{array}$ & $\begin{array}{l}\text { Em } 2019 \text { foi de aproximadamente } \\
\qquad 65 \%\end{array}$ \\
\hline Proprietário & S.E. Palmeiras & Prefeitura de São Paulo \\
\hline Administrador & WTorre Properties/Arenas AEG & $\begin{array}{c}\text { Allegra Pacaembu/ } \\
\text { Consórcio PATRIMÔNIO SP }\end{array}$ \\
\hline Arquiteto & Edo Rocha Arquiteturas & $\begin{array}{c}\text { Escritório Técnico Ramos de } \\
\text { Azevedo }\end{array}$ \\
\hline Mandante & S.E. Palmeiras & $\begin{array}{l}\text { FPF; (eventualmente, Santos; } \\
\text { Palmeiras; Corinthians e São } \\
\text { Paulo). }\end{array}$ \\
\hline
\end{tabular}

Fonte:Revista Exame - https://exame.abril.com.br - Acesso em 20/04/2018

O mesmo pode ser observado com a Arena Corinthians, localizada no distrito de Itaquera, onde o clube tem número de torcedores bem acima da média da cidade, consagrando-se como "casa corintiana".

O modelo de estádio como ponto central da matriz de receitas do clube requer localização precisa, em consonância com os pontos de maior concentração de seus torcedores.

\subsubsection{O Allianz Parque na Economia do Futebol}

O futebol, apesar de fazer parte desse todo, procura desastradamente, por intermédio de boa parte de seus "interessados envolvidos" (locução traduzida por 
"stakeholders", em inglês), desbordar-se do processo econômico mundial e nacional, como se isso fosse possível, para não ter que aplicar às condutas, regras e controles da racionalidade administrativa e econômica, em desenvolvimento oposto às boas práticas gerenciais e à busca de estabilidade financeira. Em vez de assumir a pertinência, busca criar um mundo próprio que 0 isente de acompanhamento e avaliação. Um dos maiores ativos da economia do futebol é o chamado "direito federativo" 88 dos jogadores, que apresenta trajetória bem semelhante àquela que Marx descreveu com relação às obras de arte. Como na obra de arte, o valor de um jogador não pode ser comparado ao de nenhum outro, pois são coisas distintas, que não podem ser mensuradas por "horas trabalhadas", e fogem totalmente ao conceito de "commodity". Isso permite uma criação de valor específico que pode gerar riqueza significativa, sem parâmetros de controle, possibilitando ganhos imensos e desvios consideráveis. Por conta dessa capacidade de gerar riqueza instantânea e sideral, os envolvidos no negóciofutebol esforçam-se por tratá-lo como algo que não deve ser acompanhado da mesma forma que outros setores da economia, emprestando a ele caráter exclusivamente lúdico. A argumentação é astuciosa , todavia frágil.

A economia do futebol é parte do todo e se confronta com os ciclos econômicos como tal.

Segundo José Jobson de Andrade Arruda ${ }^{89} \mathrm{em}$ sua tese de doutoramento:

\footnotetext{
"O estudo dos ciclos econômicos, para os americanos, ou das flutuações econômicas para os franceses, está intimamente associado ao estudo das conjunturas. A palavra conjuntura evoca ideias diversas que se ressentem de parentesco com a palavra "junção" ( reunião de elementos diversos) e de sua semelhança com a palavra "conjectura" (cálculo de elementos incertos)". (ARRUDA, 1980, p.89).
}

${ }^{88}$ Direito Federativo é único e só pode ser detido por um clube devidamente registrado. ${ }^{89}$ ARRUDA, José Jobson de. O Brasil no comércio colonial. São Paulo: Ática, 1980, p.89. 
Atividade, conjuntura e ciclos econômicos estão associados e tal realidade não pode ser negada.

Em 2007, com a definição do Brasil como sede da Copa do Mundo de 2014, a necessidade de construção de estádios significou a criação de vetor que provocaria um novo ciclo econômico no futebol, a partir da construção dos estádios com padrão-FIFA, que se transformaram em estádios-shoppings, ponto central desse trabalho. Além dos estádios, outras atividades ganharam tração com a escolha do Brasil como sede. Os clubes foram abrangidos por esse novo ciclo.

Os balanços da Sociedade Esportiva Palmeiras, comparados entre 2007 e 2018, recorte utilizado para a pesquisa, mostram a relação dos ativos, em particular do estádio como fator gerador de receita, e também indutor de uma nova matriz econômica sustentável para o clube (vide anexos $\mathrm{A}$ a K).

\subsection{Demonstrativo das Receitas}

O simples cotejamento entre as receitas obtidas pela Sociedade Esportiva Palmeiras nos anos de 2007 a 2013 e as receitas obtidas pela Sociedade Esportiva Palmeiras a partir da inauguração do Allianz Parque, demonstra o exponencial aumento a partir 2014:

Tabela 33 - Receitas Operacionais (em milhões R\$)

\begin{tabular}{|c|c|}
\hline \multicolumn{2}{|c|}{ Sociedade Esportiva Palmeiras - Palestra Italia } \\
\hline Ano & Total \\
\hline 2007 & 263.557 \\
\hline 2008 & 264.448 \\
\hline 2009 & 162.355 \\
\hline 2010 & 201.907 \\
\hline 2011 & 142.901 \\
\hline 2012 & 177.869 \\
\hline 2013 & 178.420 \\
\hline
\end{tabular}




\begin{tabular}{|c|c|}
\hline \multicolumn{2}{|c|}{ Sociedade Esportiva Palmeiras - Estádio Allianz Parque } \\
\hline Ano & Total \\
\hline 2014 & 252.732 \\
\hline 2015 & 351.480 \\
\hline 2016 & 468.644 \\
\hline 2017 & 503.682 \\
\hline 2018 & 653.852 \\
\hline
\end{tabular}

Fonte:Sociedade Esportiva Palmeiras-www.palmeiras.com.br - acesso em 14/04/2018, Jornal Estadão - www.estadao.com.br - Acesso em: 16/05/2019.

Os próximos gráficos mostram a importância da introdução do Allianz Parque na matriz econômica da Sociedade Esportica Palmeiras.

\section{Gráfico 07 - Evolução da Receita Operacional ao longo dos anos (em milhões R\$)}

\section{Evolução da receita operacional ao longo dos anos (RS MI)}

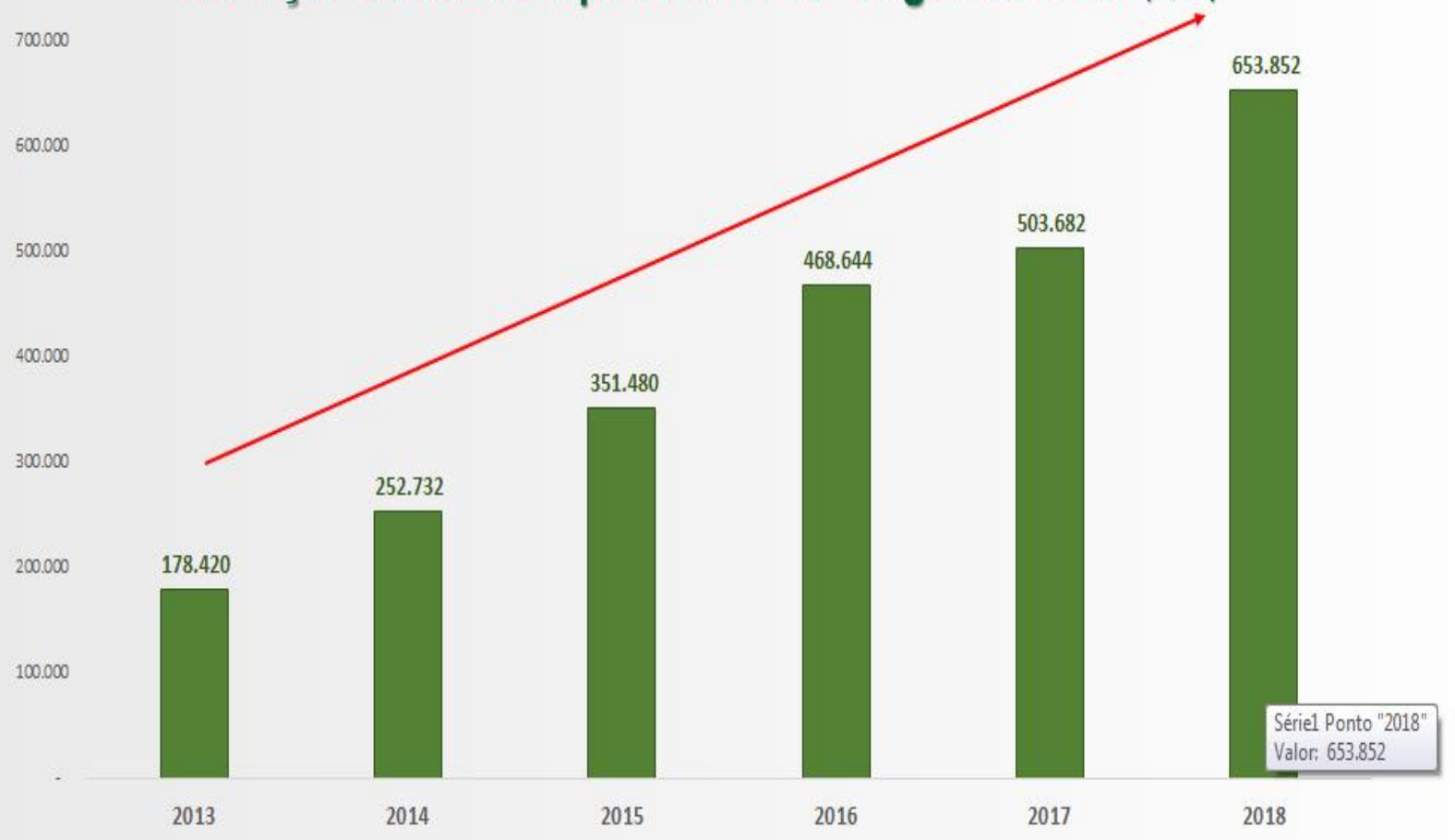

Fonte: Sociedade Esportiva Palmeiras - Presidência - Acesso em 18/03/2019 
Um dos efeitos mais virtuosos, mais importantes na vida econômica do Palmeiras, foi a conquista de Patrimônio Líquido positivo, após tantos anos no "vermelho". O Patrimônio Líquido é um dos conceitos mais relevantes do balanço patrimonial e é utilizado por todo o mercado para a avaliação da saúde da empresa. Trata-se da diferença entre os valores do ativo e do passivo de uma entidade. Raros clubes de futebol logram ter PL positivo.

\section{Gráfico 08 - Patrimônio Líquido: Positivo (em milhões R\$)}

100

\section{Patrimônio Liquido: Positivo (rs un)}

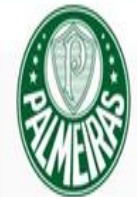

$(50)$

$[100]$

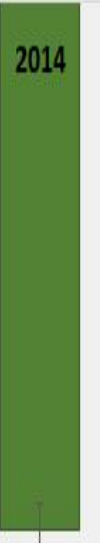

(128)
60

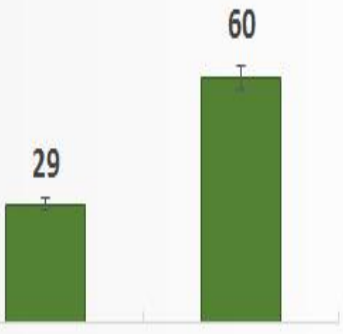

2017 2018

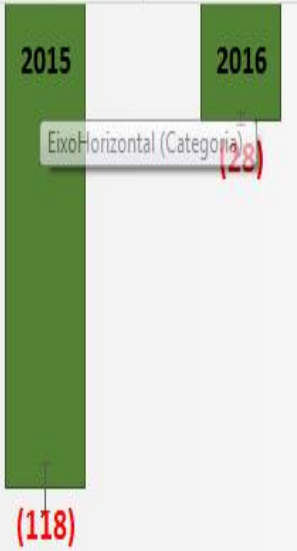

(118)
Realizado 2018

R\$ 30 Milhões

$(150)$

Fonte: Sociedade Esportiva Palmeiras - Presidência - Acesso em 18/03/2019 
Gráfico 09 - Receitas por Tipo - SEP - Período Allianz Parque 2017

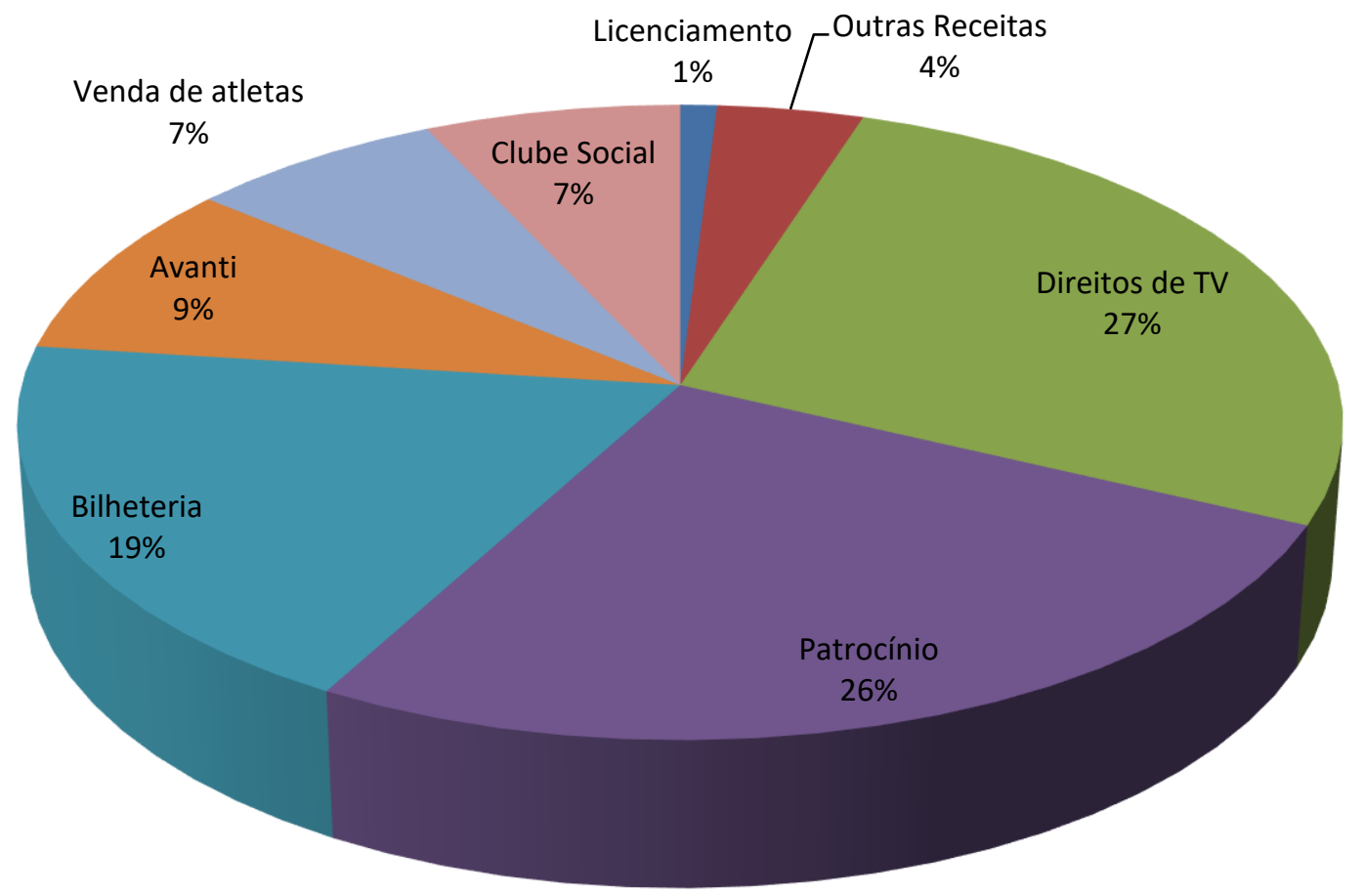

Fonte: Sociedade Esportiva Palmeiras - Presidência - Acesso em 18/03/2019. 
Gráfico 10 - Receita por Tipo - SEP - Período Allianz Parque 2018

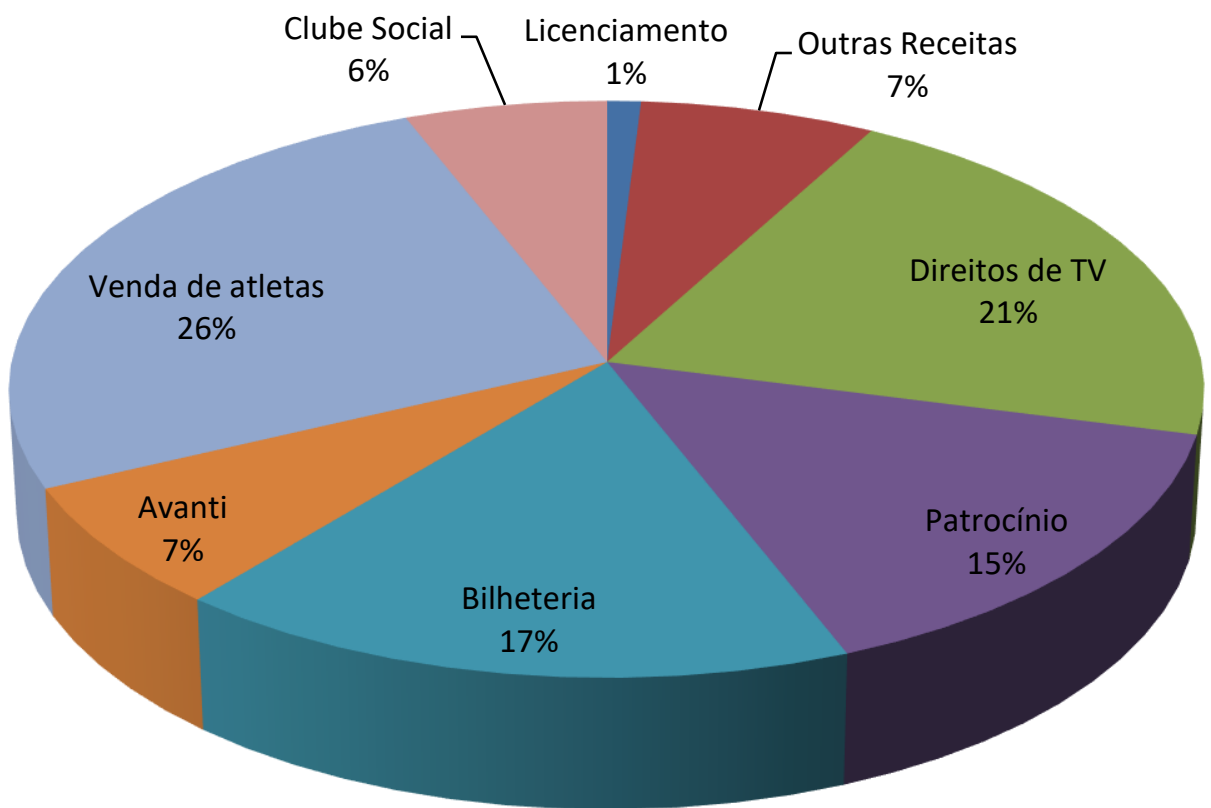

Fonte: Sociedade Esportiva Palmeiras - Presidência - Acesso em 18/03/2019 
O futebol brasileiro atuou com vários ativos principais, embora com dimensões bastante diferenciadas em termos de valores e participação nas receitas totais dos clubes. A princípio, a arrecadação da bilheteria do jogo foi relevante, mas com baixo valor monetário. A seguir, o direito federativo, no molde inicial, tratado popularmente como "direito do passe do jogador", amparado pela Lei do Passe ${ }^{90}$, depois as vendas de atletas e os direitos de transmissão por TV. Os clubes não perseguiam ativ0os que pudessem controlar e harmonizar com os respectivos torcedores, maior patrimônio potencial que possuíam. O estádio era visto como passivo, como custo.

O estádio só voltou ao proscênio a partir de 2014, com o Allianz Parque conduzindo esse processo, suscitando possibilidade de arrecadação autônoma, que alterou enormemente a dinâmica de auferição de receitas, conforme as tabelas e gráficos relacionados. O estádio também proporcionou renda indireta, uma vez que a respectiva entronização, com o destaque que ganhou não só pelo conforto, segurança e oferecimento de serviços, como pela imagem fulgurante, que passou a ser ícone do clube e da torcida, criando valor publicitário imagético, associado à transmissão de TV, a contemplar milhões de espectadores, catapultando a verba de patrocínio.O Allianz Parque foi a combinação do estádio monumento arquitetônico com o estádio monumento econômico.

Os anunciantes, as empresas interessadas na visibilidade do negócio-futebol, do "business futebol", aumentaram significativamente suas verbas nos clubes que possuíam as condições acima enunciadas e o Palmeiras foi o maior beneficiário desse movimento, que agregou valor à marca. Isso ocorre pelas condições específicas do seu modelo, onde avulta a segurança do clube, pois o Pameiras não contraiu dívidas com relação à construção do estádio, o que poderia disseminar o risco ao negócio, como ocorreu com a Arena Corinthians.

\footnotetext{
${ }^{90}$ A Lei no 9.615 de 24 de março de 1998, mais conhecida como "Lei do Passe Livre" , é uma norma jurídica brasileira sobre desporto baseada nos princípios presentesna Constituição, e cujo efeito mais conhecido foi ter mudado a legislação sobre o passe de jogadores de futebol, revogando a chamada Lei Zico (Lei no 8.672, de 6 de julho de 1993).
} 


\subsection{A mudança econômica e a matriz financeira}

\subsubsection{Governança e a Matriz Econômica}

A matriz econômica pesquisada se torna viável a partir do modelo desenvolvido pelo Allianz Parque:

a) estádio multiuso;

b) clube sem ônus com relação à construção do estádio;

c) despesa do clube apenas com a sustentação operacional dos dias de jogos;

d) inexistência de financiamento ou aportes do poder público;

e) participação do clube nas receitas extra-futebol;

f) identificação da torcida com o estádio;

g) localização propícia para a respectiva torcida;

h) adequação do programa sócio-torcedor à ocupação do estádio;

i) facilidade de acesso e existência de estacionamento compatível com o público-alvo.

O alinhamento acima aludido não é meta simples e depende de planejamento acurado, que no caso do Palmeiras, em parte, ocorreu, como citado, pela aglutinação dos trabalhadores da Matarazzo, dos fundadores, do envolvimento de Ermelino Matarazzo com o clube, com a fixação herdada dos descendentes de italianos nos bairros em volta do estádio e do eixo de crescimento e de distribuição do transporte público na cidade.Nem sempre os clubes conseguiram tal conjunção de fatores.

Contudo, o sucesso da empreitada que leva à matriz econômica independente e estável não se esgota nesses atributos, por si sós, complexos. É preciso, inescapavelmente, da qualidade da gestão, fator intangível, normalmente conhecido, mas, desprezado. Concretizado o modelo descrito anteriormente, a forma de administração e o processo de gestão, que, juntos, constituem o que se passou a chamar de governança, ganha importância vital, que não pode ser em nenhum momento descurada. 
Detalharemos em capítulo posterior a questão considerada fundamental: os fatores intangíveis no futebol são enunciados nas discussões sobre gestão, todavia não são levados devidamente em conta na hora de se estudar modelos gerenciais, implantá-los e avaliá-los, provavelmente porque isso requer um cuidado especial que o futebol parece não cultuar.

Em primeiro lugar, destacam-se as normas jurídicas e institucionais que o clube possui e que darão segurança ao negócio. O futebol é um potente negócio que movimenta bilhões de reais, mas recai sobre ele uma sombra lúdica, associada à paixão tida como intrínseca, que associadas suscitam um olhar de complacência,um "perdão", "um fechar de olhos para", um "waiver"12, como diriam os ingleses, a introduzir métodos personalistas e distantes dos cuidados empresariais, envoltos numa embalagem de romantismo, que existe, mas é aí mal aplicado. Onde há aporte financeiro, existe busca por segurança e previsibilidade nos investimentos. E o futebol procura fugir disso. Há clubes que até hoje, mesmo inseridos na economia do futebol vigente, não respeitam contratos e possuem órgãos de controle lenientes.

A seguir, é relevante a forma como as direções dos clubes atuam, na prática. Mesmo diante de regras estabelecidas, há um espaço para que elas as interpretem de modo diverso e distante da realidade requerida pelos investidores e pelo mundo dos negócios contemplado. Mudanças no estatuto social com casuísmos políticos internos, gastos sem controle, ainda que amparados em receitas existentes, política de venda de atletas, instabilidade da equipe para manter a atração do torcedor, que é fator decisivo na receita e outras questões são cruciais e riscos nesse processo de garantia de desempenho. Gestões diversas, muitas vezes pertencentes até ao mesmo grupo político que se sucede no poder, provocam resultados diferentes, com impactos consideráveis, isso,quando não produzem consequências antagônicas à gestão anterior, utilizando o mesmo arcabouço jurídico institucional.

Portanto, cabe uma forma de avaliação do sistema gerencial completo e um modo de acompanhá-lo permanente, com o estabelecimento de metas absolutamente claras e que assegurem o êxito da empreitada. 
As administrações de Paulo Nobre ${ }^{91}$ e Maurício Galiotte ${ }^{92}$, no Palmeiras; a sequência Andrés Sanchez ${ }^{93}$, Mário Gobbi94, Roberto Andrade ${ }^{95}$, e novamente Andrés Sanchez, no Corinthians; Juvenal Juvêncio ${ }^{96}$, Carlos Miguel Aidar ${ }^{97}$, Carlos Augusto de Barros e Silva ${ }^{98}$, no São Paulo; todas coincidentemente oriundas das mesmas respectivas correntes políticas, são ilustrações claras do peso das idiossincrasias gerenciais nos resultados econômicos do clube, agindo assim como fator decisivo, e em direções opostas, na construção de matriz econômica sustentável. Abaixo, segue quadro com resultados sintéticos de cada gestão. (Vide Anexo $L$ ao Anexo $G$ ).

Os gráficos e tabelas do Palestra Italia e do Allianz Parque (reproduzidos nos capítulos anteriores) traduzem, com a força de seus respectivos números, a comparação entre os resultados suscitados, com destaque para a diferença de renda gerada.

Paulo Nobre foi eleito pela primeira vez Presidente da Sociedade Esportiva Palmeiras em 2013, quando o clube estava na Série B do Campeonato Brasileiro e mandava seus jogos no Palestra Italia. Neste período a receita total era bem menor em comparação com a atual. Somente após a inauguração do Allianz Parque, como demonstrado, as receitas aumentaram substancialmente, em especial pela arrecadação com bilheteria e Sócio Avanti. Paulo Nobre foi reeleito, tendo exercido seu mandato até 2016. Em 2017 foi eleito Presidente Maurício Galiotte, que

91 Paulo de Almeida Nobre, mais conhecido como Paulo Nobre, é conselheiro da Sociedade Esportiva Palmeiras desde 1997 e foi presidente do Clube nos anos de 2013 e 2014.

92 Maurício Precivalle Galiotte foi eleito presidente da Sociedade Esportiva Palmeiras para o biênio 2017/2018, substituindo Paulo Nobre.

${ }^{93}$ Andrés Navarro Sánchez é o atual presidente do Sport Club Corinthians Paulista.

${ }_{94}$ Mário Gobbi Filho foi presidente do Sport Clube Corinthians Paulista nos anos de 2012 a 2015.

${ }^{95}$ Roberto de Andrade Souza foi presidente do Sport Clube Corinthians Paulista nos anos de 2015 a 2018.

96 Juvenal Juvêncio foi presidente do São Paulo Futebol Clube nos anos de 2008 a 2014.

${ }^{97}$ Carlos Miguel Castex Aidar foi presidente do São Paulo Futebol Clube nos ano de 1986 a 1988 e nos anos de 2015.

${ }^{98}$ Carlos Augusto de Barros e Silva é o atual presidente do São Paulo Futebol Clube (2015 a 2020). 
assumiu o clube em situação financeira melhor que seu antecessor, período em que a receita do clube continuou crescendo.

De toda forma, no caso do Palmeiras, o Palestra Italia encerra suas atividades com a demolição na gestão Luiz Gonzaga de Mello Belluzzo, e na gestão de Arnaldo Tirone, que faz a transição entre o Palestra Italia e o Allianz Parque, inaugurado na gestão Paulo Nobre.

A diferença de resultados no desempenho e no papel exercido pelos dois estádios, para que compreendamos a magnitude da transformação havida, é apresentada no capítulo seguinte, com a história quantitativa falando por si mesma. 


\section{CAPÍTULO IV - PALESTRA ITALIA X ALLIANZ PARQUE}

Do Palestra Italia ao Allianz Parque, a Sociedade Esportiva Palmeiras faz uma viagem significativa na sua história econômica. Não são apenas os números que seguem, é um conjunto que podemos chamar de notável e conquistador. Ao impacto de geração de riqueza se alinham a comutação do estádio-arquibancada para o estádio-shopping, a metamorfose do torcedor-apaixonado para o torcedorcliente, o predomínio da indústria do entretenimento, o florescimento do sóciotorcedor em bases significativas, o reconhecimento do clube como paradigma de independência financeira, disputando com o Flamengo a liderança de arrecadação de receitas no Brasil. Utilizando o mote de Juscelino Kubitschek, mutatis mutandis, foram "40 anos em 4", considerado o tempo real de construção. Após a inauguração do Allianz Parque, em novembro de 2014, não foi por coincidência que - Palmeiras realizou as receitas que seguem abaixo e conquistou a Copa do Brasil de 2015 e os Campeonatos Brasileiros de 2016 e 2018, depois de longos anos na fila por títulos.

\subsection{Resultado Econômico Financeiro}

A seguir, colacionamos dados relativos às receitas operacionais do Palestra Italia e do Allianz Parque, no período de 2007 a 2018.

(a) Receitas Operacionais: Palestra Italia 
Tabela 34 - Receitas operacionais de 2007 - 2008 (x 1.000 R\$)

\begin{tabular}{|c|c|c|c|c|c|c|c|c|c|}
\hline & \multirow[b]{3}{*}{$\underline{\text { notas }}$} & \multicolumn{4}{|c|}{2008} & \multicolumn{4}{|c|}{2007} \\
\hline & & \multicolumn{2}{|c|}{ Futebol } & \multicolumn{2}{|l|}{$\begin{array}{l}\text { Clube } \\
\text { social e }\end{array}$} & \multicolumn{2}{|c|}{ Futebol } & \multicolumn{2}{|l|}{$\begin{array}{c}\text { Clube } \\
\text { social e }\end{array}$} \\
\hline & & profissional & amador & $\begin{array}{l}\text { esportes } \\
\text { amadores }\end{array}$ & $\underline{\text { Total }}$ & profissional & Amador & $\begin{array}{r}\text { esportes } \\
\text { amadores }\end{array}$ & $\underline{\text { Total }}$ \\
\hline \multicolumn{10}{|l|}{$\begin{array}{l}\text { Receitas } \\
\text { operacionais }\end{array}$} \\
\hline $\begin{array}{l}\text { Direitos de } \\
\text { transmissão de } \\
\text { TV }\end{array}$ & & 30.371 .634 & & & 30.371 .634 & 25.283 .228 & & & 25.283 .228 \\
\hline $\begin{array}{l}\text { Publicidade e } \\
\text { patrocínio }\end{array}$ & & 16.666 .013 & & & 16.666 .013 & 9.541 .460 & & & 9.541 .460 \\
\hline $\begin{array}{l}\text { Arrecadação de } \\
\text { jogos }\end{array}$ & & 17.570 .408 & & & 17.570 .408 & 7.539 .494 & & & 7.539 .494 \\
\hline $\begin{array}{l}\text { Negociação de } \\
\text { atletas }\end{array}$ & & 43.456 .357 & & & 43.456 .357 & 12.070 .384 & & & 12.070 .384 \\
\hline $\begin{array}{l}\text { Timemania e } \\
\text { outros }\end{array}$ & & 869.959 & & & 869.959 & & & & \\
\hline \multicolumn{10}{|l|}{$\begin{array}{l}\text { Arrecadação } \\
\text { social }\end{array}$} \\
\hline \multicolumn{10}{|l|}{$\begin{array}{l}\text { Licenciamento } \\
\text { da marca }\end{array}$} \\
\hline \multicolumn{10}{|l|}{$\begin{array}{l}\text { Departamentos } \\
\text { amadores }\end{array}$} \\
\hline $\begin{array}{l}\text { Rendas } \\
\text { diversas }\end{array}$ & & 3.794 .372 & & & 3.794 .372 & 2.252 .135 & & & 2.252 .135 \\
\hline & & 112.728 .743 & & & 112.728 .743 & 65.145 .701 & & & 65.145 .701 \\
\hline
\end{tabular}

Fonte: Sociedade Esportiva Palmeiras- www.palmeiras.com.br- Acesso em 17/05/2019.

Como demonstrado na tabela 34, de 2007 para 2008 houve um acréscimo de aproximadamente $73 \%$ nas receitas operacionais do clube, com destaque para o aumento no item "Negociação de Atletas". O clube dependia muito dessa rubrica. 
Tabela 35 - Receitas operacionais de 2008 - 2009 (x 1.000R\$)

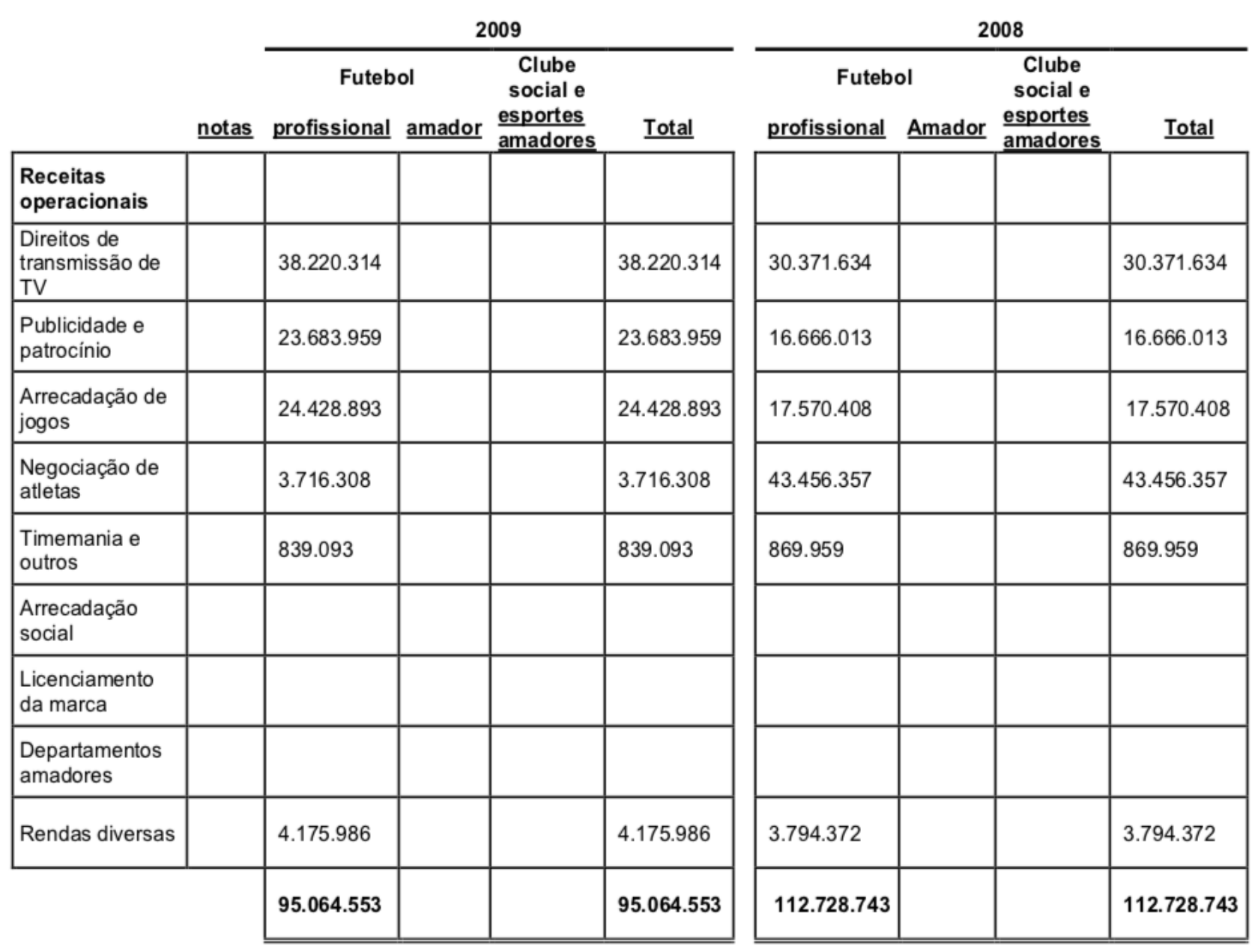

Fonte: Sociedade Esportiva Palmeiras - www. palmeiras.com.br- Acesso em 17/05/2009.

Verifica-se na tabela 35, que de 2008 para 2009 houve um decréscimo de aproximadamente $16 \%$ nas receitas operacionais, destacando-se a diminuição no item "Negociação de Atletas". 
Tabela 36 - Receitas operacionais de $2009-2010$ (x1.000R $\$$ )

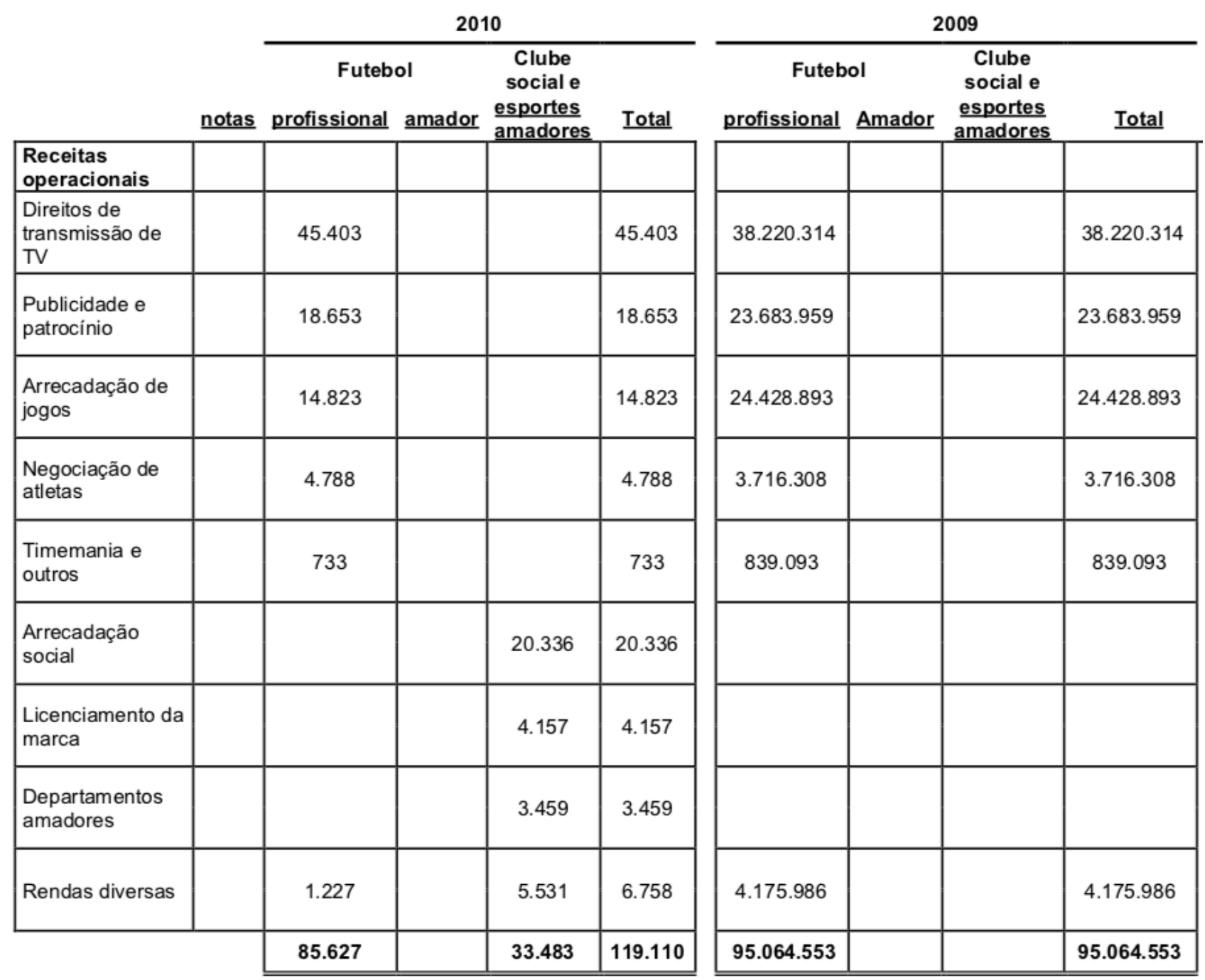

Fonte:Sociedade Esportiva Palmeiras-www.palmeiras.com.br - acesso em 14/04/2018 e 17/05/2009.

Na próxima página podemos observar as mudanças mais relevantes.

Na tabela 36 acima, observa-se que de 2009 para 2010 houve um acréscimo de aproximadamente $25 \%$ nas receitas operacionais, com aumento no item "Direitos de transmissão de TV" e a inclusão de itens como "Arrecadação Social", "Licenciamento da marca", "Departamento amadores" e "Rendas Diversas

No mesmo período, cumpre destacar a diferença de aproximadamente $13 \%$ de acréscimo em relação aos direitos de transmissão e de imagem de 2010 para 2009. Em relação à bilheteria houve um decréscimo de aproximadamente 5\%. 
Tabela 37 - Receitas operacionais de 2010 - 2011 (x1.000R\$)

\begin{tabular}{|c|c|c|c|c|c|c|c|c|c|}
\hline & \multirow[b]{2}{*}{$\underline{\text { notas }}$} & \multicolumn{4}{|c|}{2011} & \multicolumn{4}{|c|}{2010} \\
\hline & & $\begin{array}{r}\text { Futeb } \\
\text { profissional } \\
\end{array}$ & $\underline{\text { amador }}$ & $\begin{array}{c}\text { Clube } \\
\text { social e } \\
\text { esportes } \\
\text { amadores } \\
\end{array}$ & $\underline{\text { Total }}$ & $\begin{array}{r}\text { Futeb } \\
\text { profissional }\end{array}$ & amador & $\begin{array}{c}\text { Clube } \\
\text { social e } \\
\text { esportes } \\
\text { amadores } \\
\end{array}$ & $\underline{\text { Total }}$ \\
\hline \multicolumn{10}{|l|}{$\begin{array}{l}\text { Receitas } \\
\text { operacionais }\end{array}$} \\
\hline $\begin{array}{l}\text { Direitos de } \\
\text { transmissão de TV }\end{array}$ & & 46.771 & & & 46.771 & 45.403 & & & 45.403 \\
\hline $\begin{array}{l}\text { Publicidade e } \\
\text { patrocínio }\end{array}$ & & 44.649 & & & 44.649 & 18.653 & & & 18.653 \\
\hline $\begin{array}{l}\text { Arrecadação de } \\
\text { jogos }\end{array}$ & & 12.004 & 2 & & 12.006 & 14.823 & & & 14.823 \\
\hline $\begin{array}{l}\text { Negociação de } \\
\text { atletas }\end{array}$ & & 12.754 & 39 & & 12.793 & 4.788 & & & 4.788 \\
\hline $\begin{array}{l}\text { Timemania e } \\
\text { outros }\end{array}$ & & 1.756 & & & 1.756 & 733 & & & 733 \\
\hline Arrecadação social & & & & 15.702 & 15.702 & & & 20.336 & 20.336 \\
\hline $\begin{array}{l}\text { Licenciamento da } \\
\text { marca }\end{array}$ & & & & 4.049 & 4.049 & & & 4.157 & 4.157 \\
\hline $\begin{array}{l}\text { Departamentos } \\
\text { amadores }\end{array}$ & & & & 3.041 & 3.041 & & & 3.459 & 3.459 \\
\hline Rendas diversas & & 3.205 & & 2.169 & 5.374 & 1.227 & & 5.531 & 6.758 \\
\hline & & 121.139 & 41 & 24.961 & 146.141 & 85.627 & & 33.483 & 119.110 \\
\hline
\end{tabular}

Fonte:Sociedade Esportiva Palmeiras-www.palmeiras.com.br - acesso em 14/04/2018

De 2010 para 2011 houve um acréscimo de $23 \%$ das receitas operacionais, conforme demonstrado na tabela 37, com aumento nos itens "Publicidade e Patrocínio" e "Negociação de Atletas". Direitos de transmissão: acréscimo de 3\%. No item arrecadação de jogos (bilheteria) houve um decréscimo de aproximadamente $22 \%$. 
Tabela 38 - Receitas operacionais de 2011 - 2012 (x1.000R\$)

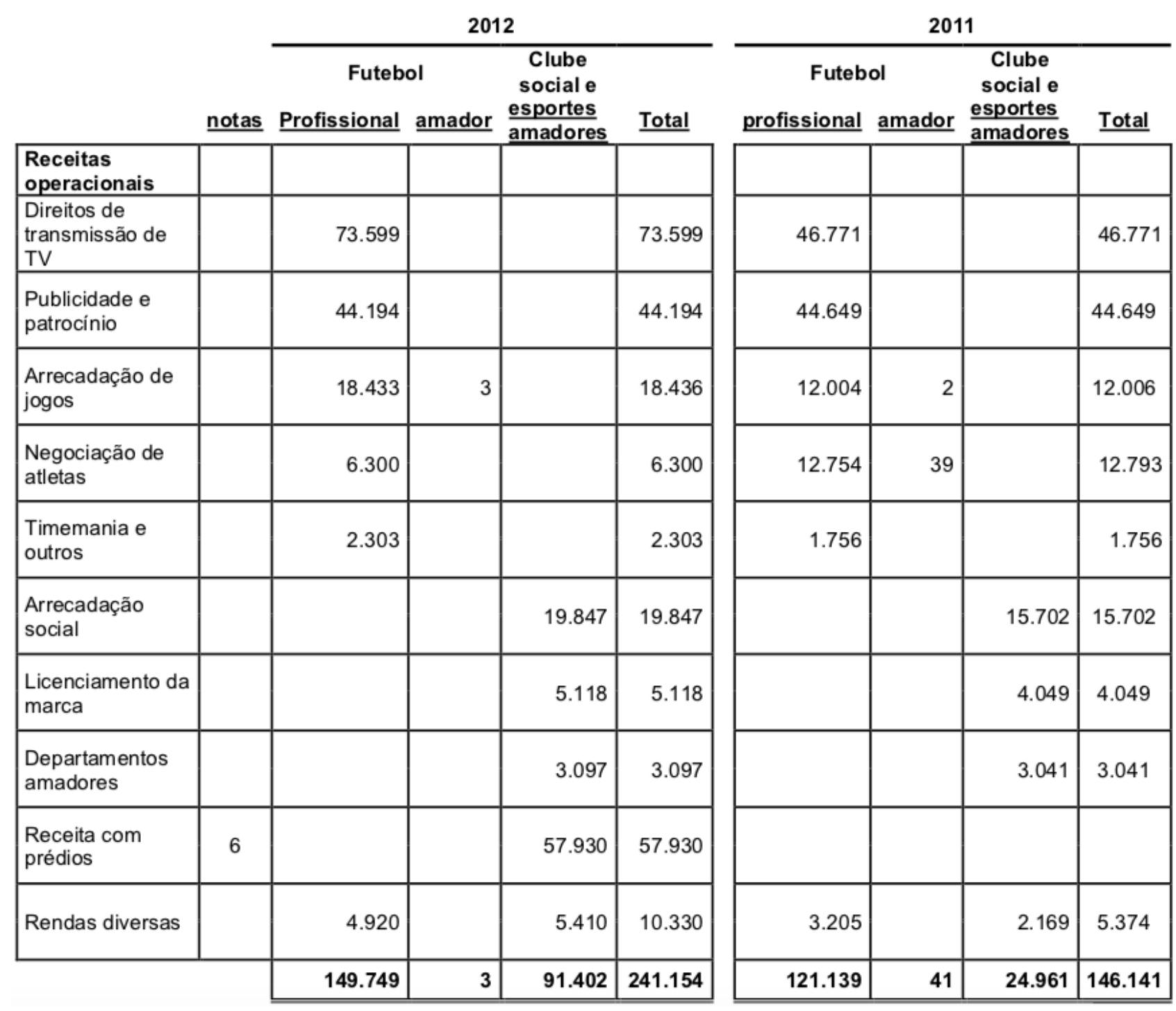

Fonte:Sociedade Esportiva Palmeiras-www.palmeiras.com.br - acesso em 14/04/2018

Conforme Tabela 38, de 2011 para 2012: acréscimo de cerca de 65\% nas receitas operacionais do clube, com destaque para o aumento nos itens "Direitos de Transmissão", "Arrecadação de jogos"e a inclusão do item "Receita com prédios". Houve um acréscimo de aproximadamente $57 \%$ sobre os direitos de transmissão e de imagem. No item arrecadação de jogos (bilheteria) houve um acréscimo de aproximadamente $53 \%$. 
Tabela 39 - Receitas operacionais de $2012-2013$ (x1.000R\$)

\begin{tabular}{|c|c|c|c|c|c|}
\hline & \multicolumn{5}{|c|}{2013} \\
\hline & \multirow[b]{2}{*}{ notas } & \multicolumn{2}{|c|}{ Futebol } & \multirow{2}{*}{$\begin{array}{c}\begin{array}{c}\text { Clube } \\
\text { social e } \\
\text { esportes } \\
\text { amadores }\end{array} \\
\end{array}$} & \multirow[b]{2}{*}{$\underline{\text { Total }}$} \\
\hline & & profissional & amador & & \\
\hline \multicolumn{6}{|l|}{$\begin{array}{l}\text { Receitas } \\
\text { operacionais }\end{array}$} \\
\hline $\begin{array}{l}\text { Direitos de } \\
\text { transmissão de } \\
\text { TV }\end{array}$ & & 76.297 & & & 76.297 \\
\hline $\begin{array}{l}\text { Publicidade e } \\
\text { patrocínio }\end{array}$ & & 24.456 & & & 24.456 \\
\hline $\begin{array}{l}\text { Arrecadação } \\
\text { de jogos }\end{array}$ & & 26.366 & 1 & & 26.367 \\
\hline $\begin{array}{l}\text { Negociação de } \\
\text { atletas }\end{array}$ & & 6.048 & & & 6.048 \\
\hline $\begin{array}{l}\text { Timemania e } \\
\text { outros }\end{array}$ & & 1.539 & & & 1.539 \\
\hline $\begin{array}{l}\text { Arrecadação } \\
\text { social }\end{array}$ & & & & 23.638 & 23.638 \\
\hline $\begin{array}{l}\text { Licenciamento } \\
\text { da marca }\end{array}$ & & & & 7.803 & 7.803 \\
\hline $\begin{array}{l}\text { Departamentos } \\
\text { amadores }\end{array}$ & & & & 5.613 & 5.613 \\
\hline $\begin{array}{l}\text { Receita com } \\
\text { prédios }\end{array}$ & 5 & & & & \\
\hline $\begin{array}{l}\text { Rendas } \\
\text { diversas }\end{array}$ & & 2.084 & & 3.036 & 5.120 \\
\hline & & 136.790 & 1 & 40.090 & 176.881 \\
\hline
\end{tabular}

\begin{tabular}{|c|c|c|c|}
\hline \multicolumn{4}{|c|}{2012} \\
\hline $\begin{array}{r}\text { Futeb } \\
\text { profissional }\end{array}$ & al & $\begin{array}{c}\begin{array}{c}\text { Clube } \\
\text { social e } \\
\text { esportes }\end{array} \\
\text { amadores } \\
\end{array}$ & $\underline{\text { Total }}$ \\
\hline 73.599 & & & 73.599 \\
\hline 44.194 & & & 44.194 \\
\hline 18.433 & 3 & & 18.436 \\
\hline 6.300 & & & 6.300 \\
\hline 2.303 & & & 2.303 \\
\hline & & 19.847 & 19.847 \\
\hline & & 5.118 & 5.118 \\
\hline & & 3.097 & 3.097 \\
\hline & & 57.930 & 57.930 \\
\hline 4.920 & & 5.410 & 10.330 \\
\hline 149.749 & 3 & 91.402 & 241.154 \\
\hline
\end{tabular}

Fonte:Sociedade Esportiva Palmeiras-www.palmeiras.com.br - acesso em 14/04/2018

Como exibido pela tabela 39, nas receitas operacionais de 2012 para 2013 houve um decréscimo de aproximadamente $27 \%$, destacando-se a diminuição nos itens "Publicidade e patrocínio" e "Arrecadação social", além de um acréscimo de aproximadamente $3,5 \%$ sobre os direitos de transmissão e de imagem. No item arrecadação de jogos (bilheteria) houve um acréscimo de aproximadamente $43 \%$. 
Tabela 40 - Receitas operacionais de 2013 - 2014 (x1.000R\$)

2014

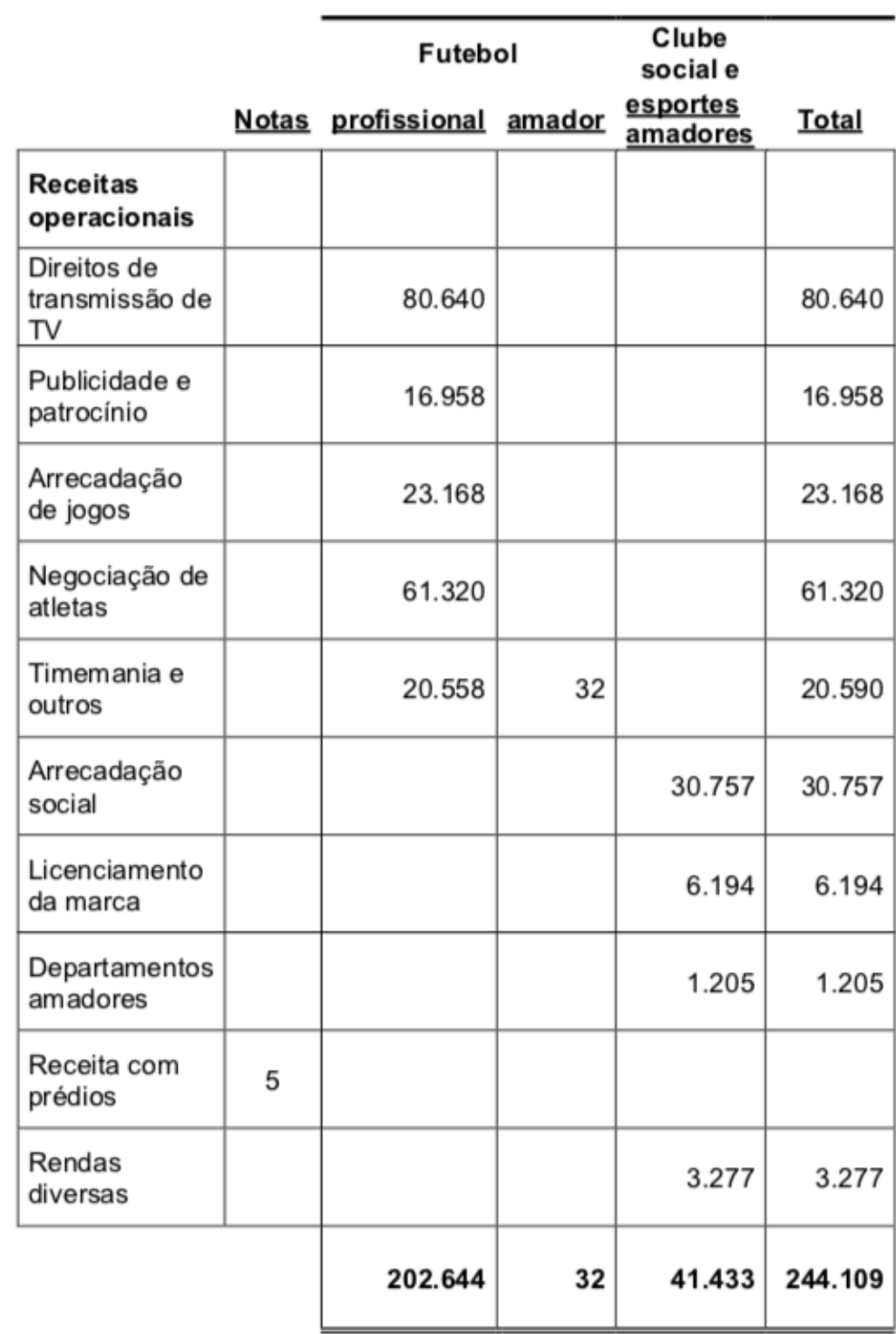

2013

\begin{tabular}{|c|c|c|c|}
\hline Futeb & ol & $\begin{array}{l}\text { Clube } \\
\text { social e }\end{array}$ & \\
\hline profissional & amador & $\begin{array}{l}\text { esportes } \\
\text { amadores }\end{array}$ & $\underline{\text { Total }}$ \\
\hline 76.297 & & & 76.297 \\
\hline 24.456 & & & 24.456 \\
\hline 26.366 & 1 & & 26.367 \\
\hline 6.048 & & & 6.048 \\
\hline 1.539 & & & 1.539 \\
\hline & & 23.638 & 23.638 \\
\hline & & 7.803 & 7.803 \\
\hline & & 5.613 & 5.613 \\
\hline 2.084 & & 3.036 & 5.120 \\
\hline 136.790 & 1 & 40.090 & 176.881 \\
\hline
\end{tabular}

Fonte:Sociedade Esportiva Palmeiras-www.palmeiras.com.br - acesso em 14/04/2018

A tabela 40 mostra que de 2013 para 2014 houve um acréscimo de aproximadamente $38 \%$ nas receitas do clube, com aumento nos itens "Negociação de atletas" e "Timemania", além de um acréscimo de aproximadamente 5,7\% sobre os direitos de transmissão e de imagem. No item arrecadação de jogos (bilheteria) houve um decréscimo de aproximadamente $13 \%$.

Conforme se verificará adiante, quando demonstradas as receitas operacionais do Allianz Parque, houve expressivo acréscimo na arredacação geral 
da Sociedade Esportiva Palmeiras, em comparação com o período anteiror à construção do estádio-shopping.

(b) Receitas Operacionais: Allianz Parque

A partir da inauguração do novo estádio as receitas do clube apresentaram expressivo aumento, como demonstram os dados a seguir colacionados. Cite-se, dentre outros, o acréscimo de aproximadamente 376\% no item arrecadação de jogos (bilheteria) entre 2014 e 2015 (tabela 41).

Tabela 41 - Receitas operacionais de 2014 - 2015 (x1.000R\$)

2015

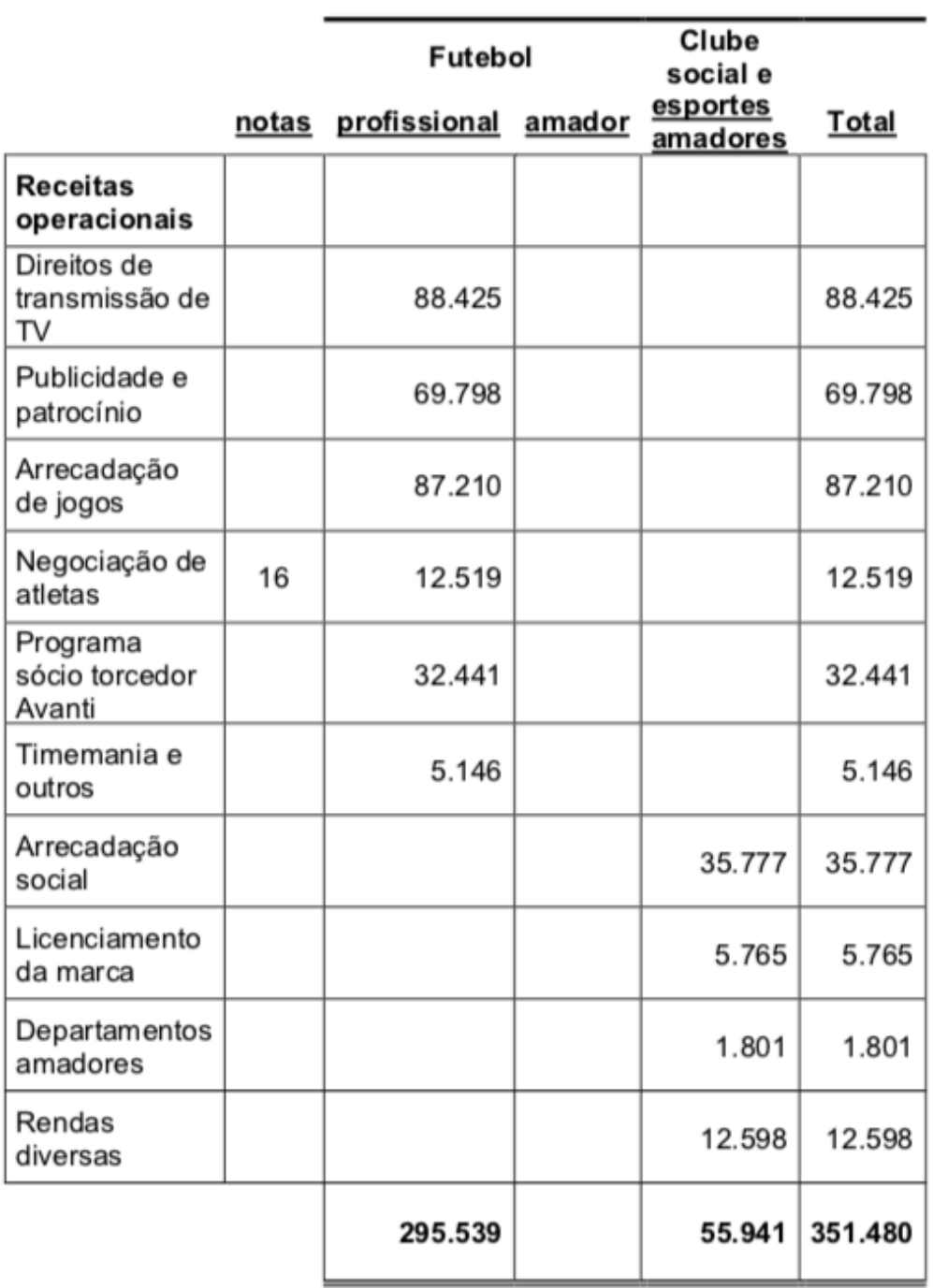

2014

\begin{tabular}{|c|c|c|c|}
\hline $\begin{array}{r}\text { Futeb } \\
\text { profissional }\end{array}$ & & $\begin{array}{c}\text { Clube } \\
\text { social e } \\
\text { esportes } \\
\text { amadores }\end{array}$ & Total \\
\hline 80.640 & & & 80.640 \\
\hline 16.958 & & & 16.958 \\
\hline 23.168 & & & 23.168 \\
\hline 61.320 & & & 61.320 \\
\hline \multirow[t]{5}{*}{20.558} & 32 & & 20.590 \\
\hline & & 30.757 & 30.757 \\
\hline & & 6.194 & 6.194 \\
\hline & & 1.205 & 1.205 \\
\hline & & 3.277 & 3.277 \\
\hline 202.644 & 32 & 41.433 & 244.109 \\
\hline
\end{tabular}

Fonte:Sociedade Esportiva Palmeiras-www.palmeiras.com.br - acesso em 14/04/2018 
Ainda conforme a tabela 41, de 2014 para 2015 houve um acréscimo de cerca de $44 \%$ nas receitas operacionais do clube, destacando-se o aumento nos itens "Publicidade e Patrocinio", "Arrecadação de jogos" e "Timemania".

Tabela 42 - Receitas operacionais de 2015 - 2016 (x1.000R\$)

2016

2015

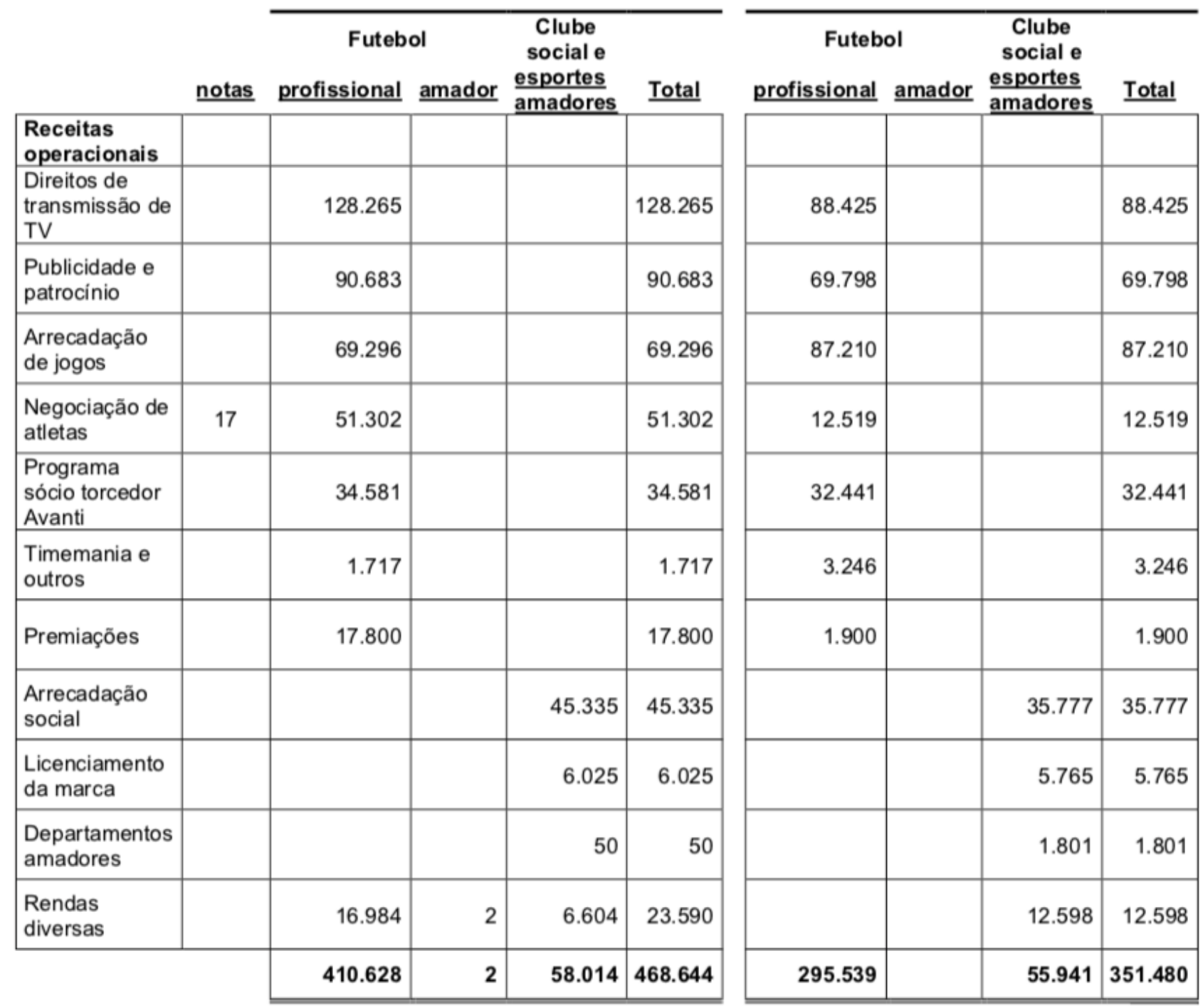

Fonte:Sociedade Esportiva Palmeiras-www.palmeiras.com.br - acesso em 14/04/2018

Percebe-se na tabela 42, que de 2015 para 2016 o acréscimo nas receitas operacionais do clube foi de aproximadamente $33 \%$, destacando-se o aumento nos itens "Direitos de Transmissão", "Publicidade e patrocínio", "Negociação de 
Atletas" e "Premiações". No item arrecadação de jogos (bilheteria) houve um decréscimo de aproximadamente $6 \%$.

Tabela 43 - Receitas operacionais de 2016 - 2017 (x1.000R\$)

2017

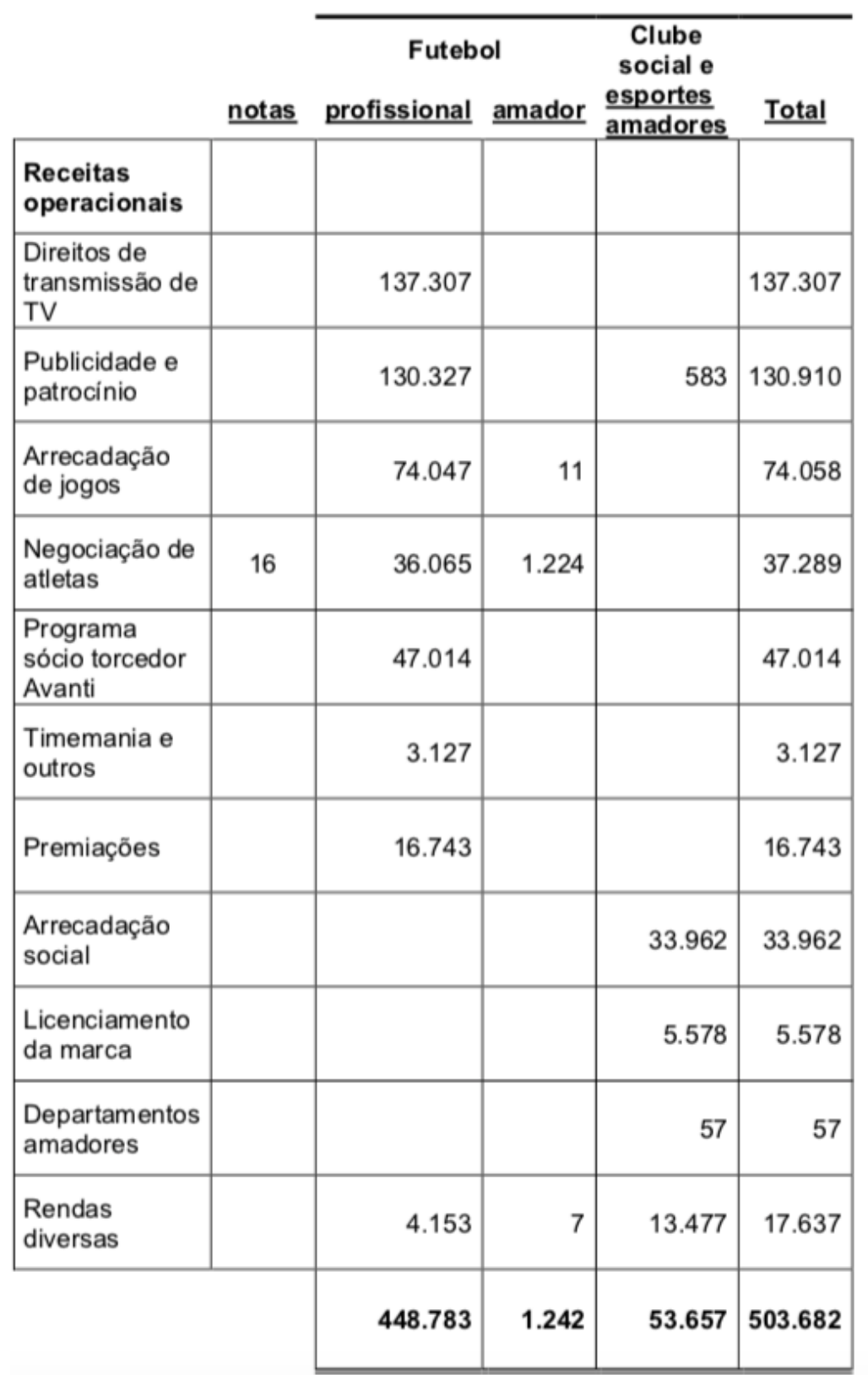

2016

\begin{tabular}{|c|c|c|c|}
\hline $\begin{array}{r}\text { Futeb } \\
\text { profissional }\end{array}$ & $\begin{array}{l}\text { ol } \\
\text { Amador }\end{array}$ & $\begin{array}{c}\begin{array}{c}\text { Clube } \\
\text { social e } \\
\text { esportes }\end{array} \\
\text { amadores }\end{array}$ & Total \\
\hline 128.265 & & & 128.265 \\
\hline 90.683 & & & 90.683 \\
\hline 69.296 & & & 69.296 \\
\hline 51.302 & & & 51.302 \\
\hline 34.581 & & & 34.581 \\
\hline 1.717 & & & 1.717 \\
\hline \multirow[t]{4}{*}{17.800} & & & 17.800 \\
\hline & & 45.335 & 45.335 \\
\hline & & 6.025 & 6.025 \\
\hline & & 50 & 50 \\
\hline 16.984 & 2 & 6.604 & 23.590 \\
\hline 410.628 & 2 & 58.014 & 468.644 \\
\hline
\end{tabular}

Fonte:Sociedade Esportiva Palmeiras-www.palmeiras.com.br - acesso em 14/04/2018

Como demonstrado na tabela 43, de 2016 para 2017 o acréscimo de receitas operacionais foi modesto, de cerca de 7,5\%, destacando-se o aumento no item "Publicidade e patrocínio". 


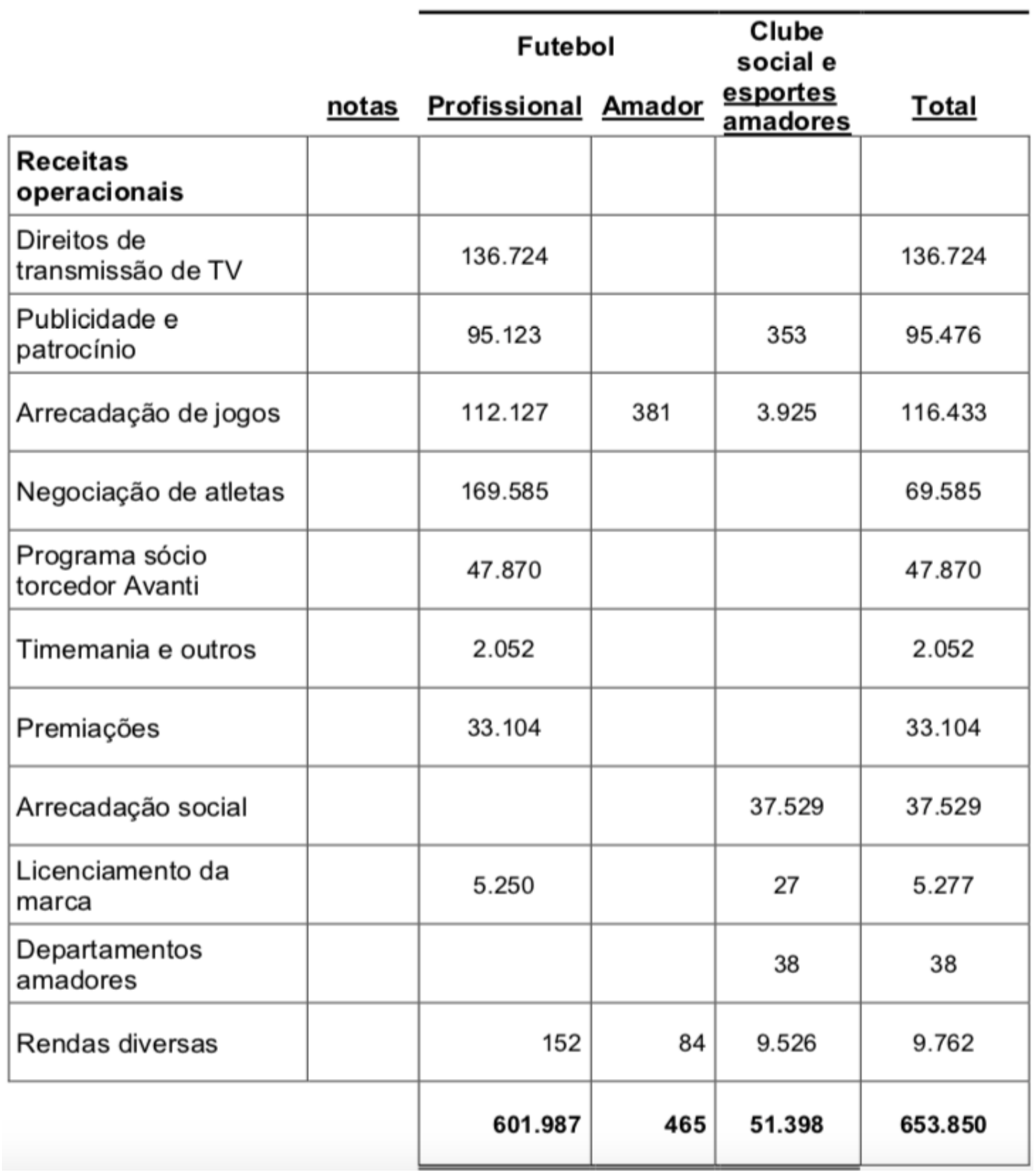

Fonte: Sociedade Esportiva Palmeiras - www.palmeiras.com.br - Acesso em 17/05/2019.

As receitas obtidas pela Sociedade Esportiva Palmeiras nos anos de 2007 a 2013 e as receitas obtidas pelo clube a partir da inauguração do Allianz Parque, demonstram o exponencial aumento a partir 2014, como demonstra a tabela 33, a seguir replicada: 
Tabela 33 - Receitas Operacionais (em milhões $\mathbf{R} \$$ ) - replicada

\begin{tabular}{|c|c|}
\hline \multicolumn{2}{|c|}{ Sociedade Esportiva Palmeiras - Palestra Italia } \\
\hline Ano & Total \\
\hline 2007 & 263.557 \\
\hline 2008 & 264.448 \\
\hline 2009 & 162.355 \\
\hline 2010 & 201.907 \\
\hline 2011 & 142.901 \\
\hline 2012 & 177.869 \\
\hline 2013 & 178.420 \\
\hline
\end{tabular}

\section{Sociedade Esportiva Palmeiras - Estádio Allianz Parque}

\begin{tabular}{|c|c|}
\hline Ano & Total \\
\hline 2014 & 252.732 \\
\hline 2015 & 351.480 \\
\hline 2016 & 468.644 \\
\hline 2017 & 503.682 \\
\hline 2018 & 653.852 \\
\hline
\end{tabular}

Fonte:Sociedade Esportiva Palmeiras-www.palmeiras.com.br - acesso em 14/04/2018, Jornal Estadão - www.estadao.com.br - Acesso em: 16/05/2019.

Da mesma forma, o Gráfico 07 (pág.136), a seguir replicado, demonstra a evolução da receita operacional do clube ao longo do período mencionado: 
Gráfico 07 - Evolução da Receita Operacional ao longo dos anos (em milhões R\$) replicado

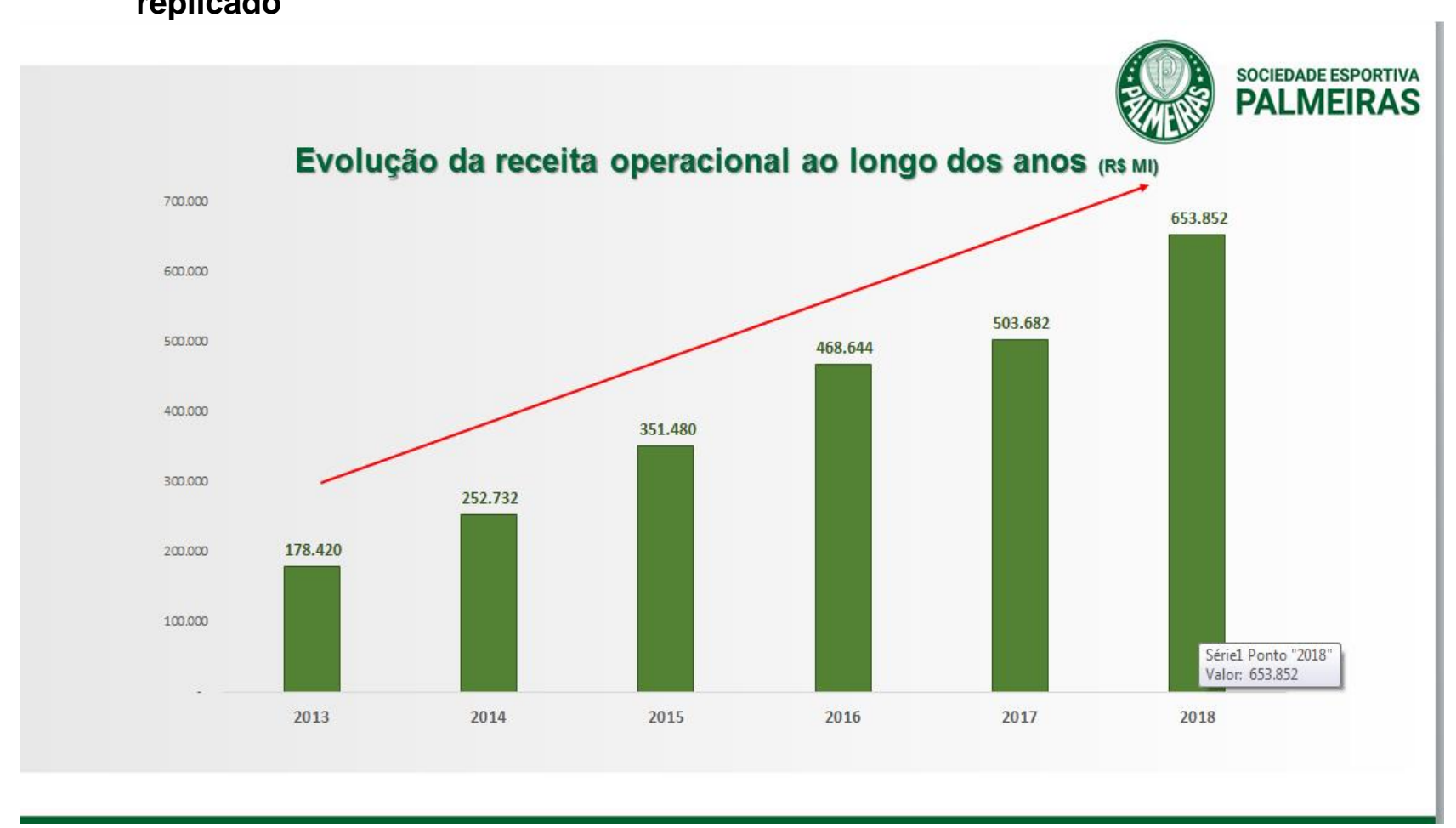

Fonte: Sociedade Esportiva Palmeiras - Presidência - Acesso em 18/03/2019

Por sua vez, o Gráfico 11 a seguir, apresenta o comparativo anual das receitas da nova Arena: 
Gráfico 11 - Comparativo anual: Receitas da arena (em Milhões $\mathbf{R} \$$ )

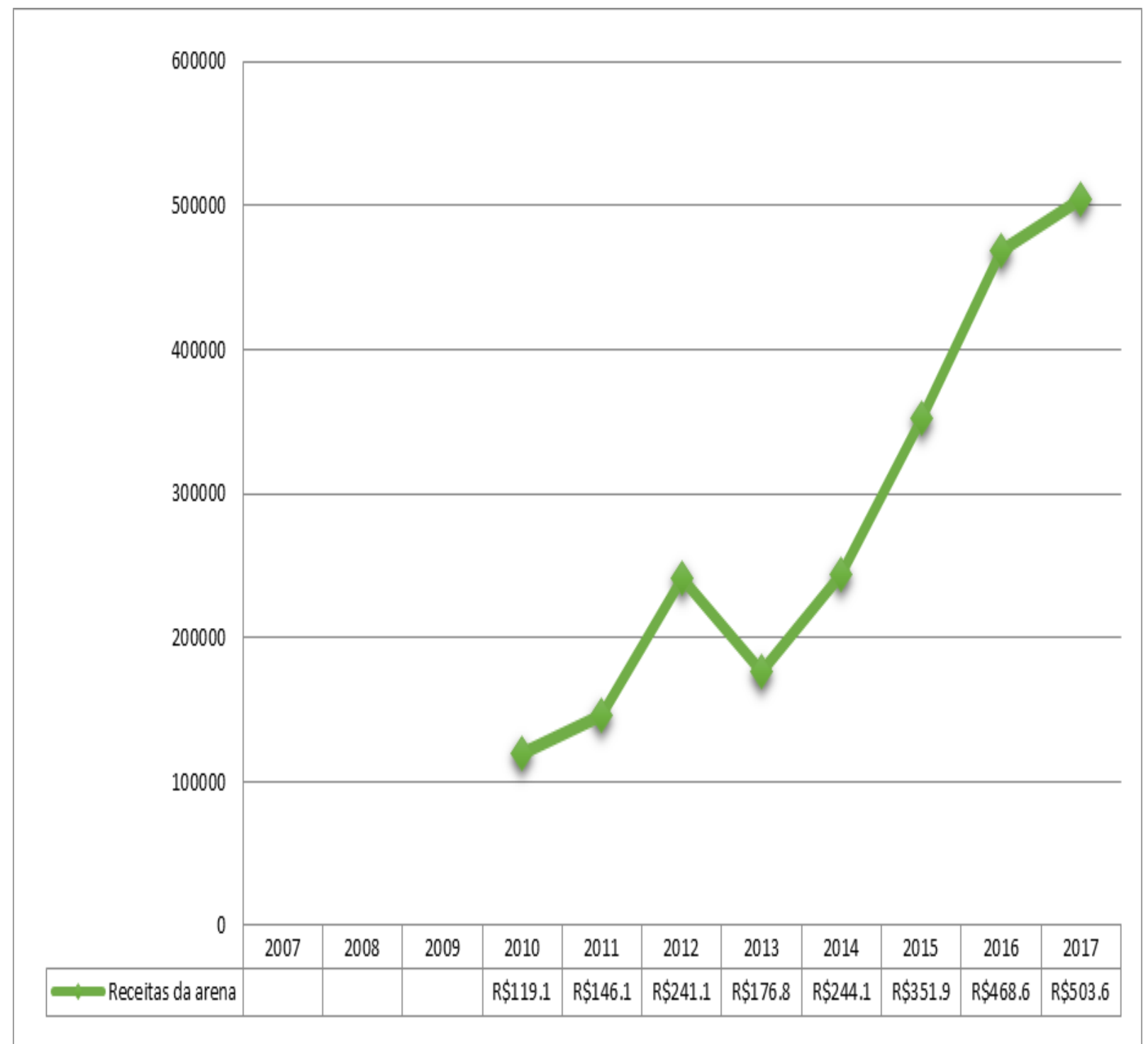

Fonte: Sociedade Esportiva Palmeiras- www.palmeiras.com.br - acesso em 12/04/2018.

A receita do clube após a inauguração do estádioshopping passou de $R \$ 119.1$ milhões com o Palestra Italia em 2010, para $R$ \$ 503,6 milhões com o Allianz Parque em 2017. 


\begin{tabular}{|c|c|c|c|c|c|}
\hline Critério & Valor (em RS mil) & Ranking & Critério* & Valor & Ranking \\
\hline Valor da Marca & 1.123 .840 & 3 & Seguidores FB & 3.989 .919 & 4 \\
\hline Receita Total & 468.644 & 3 & Seguidores Youtube & 485.740 & 1 \\
\hline Receita s/ Transferência & 417.342 & 2 & Público Médio & 32.470 & 1 \\
\hline Patrocínio e Publicidade & 90.683 & 1 & & \multirow{3}{*}{\multicolumn{2}{|c|}{ "Dados de dez/2016 }} \\
\hline Cota de TV & 128.265 & 10 & & & \\
\hline Bilheteria & 69.296 & 1 & & & \\
\hline
\end{tabular}

> Maior receita com patrocínio e publicidade do Brasil;

- Lider em público e renda;

> Sócio Torcedor de referência;

$>$ Maior canal de Youtube da América Latina;

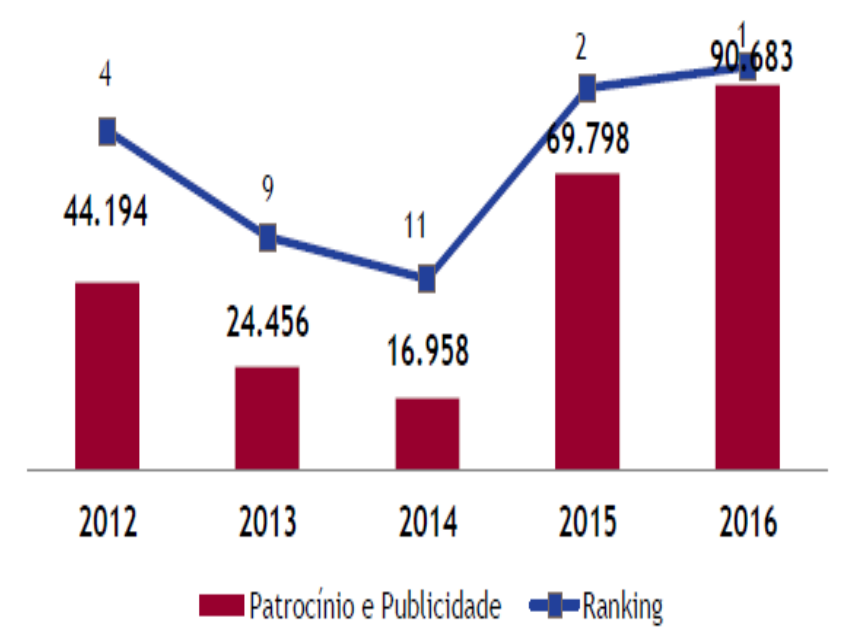

Fonte:BDO RCS Auditores Independentes-www.bdobrazilrcs.com.br - Acesso em $12 / 04 / 2018$

O Capítulo IV nos exibiu o cotejamento entre Palestra Italia e Allianz Parque, entre estádio-arquibancada e estádio-shopping. A força dos números fala por si. É a nova receita gerada pelo Allianz Parque que permite à Sociedade Esportiva Palmeiras realizar uma nova matriz econômica a proporcionar a perspectiva de independência financeira, autodeterminação e capacidade para gerar outros negócios e novas riquezas adicionais. Todavia, para se obter os desideratos de sustentabilidade, perenidade, estabilidade, avulta a necessidade de se ir além da nova matriz econômica. 
O que significa ir além? Trata-se de examinar os outros fatores indispensáveis para que a Matriz Econômica se consolide. Não basta alcançá-la, é preciso assegurá-la, e isso se dá por intermédio da governança e também por conta de outros motores, inclusive os intangíveis, que são aqueles que mais fogem à consideração e análise no futebol, por serem abstratos e por incidirem nos deslizes mais graves na gestão dos clubes. 


\section{CAPÍTULO V - ALÉM DA NOVA MATRIZ ECONÔMICA}

\subsection{Missão dos Clubes de Futebol}

Clubes de futebol profissionais enfrentam grande dicotomia: conquistar títulos ou posições de relevo nos campeonatos de que participam e sobreviver economicamente, o que implica ter matriz econômica sustentável e perene. Mutatis muntandis, buscam desempenho técnico e saldo positivo no balanço orçamentário. Com a introdução da economia do futebol e a consequente entrada de empresas, fundos do mercado financeiro, acionistas, etc, os clubes perseguem o lucro sem deixar de atuar por qualificado desempenho técnico. Nos tradicionais há a necessidade de títulos, vitórias expressivas, e o torcedor está no centro das duas demandas. É ele o esteio para a geração de riqueza que leva ao saldo positivo no orçamento e, simultaneamente, também é ele que exige desempenho esportivo. Quanto menor esse desempenho, menor o engajamento, ao longo do tempo, da grande massa de torcedores que sustenta o clube financeiramente, embora sempre haja um grupo de fanáticos-leais, não suficiente para o embasamento econômico.

Essa dicotomia não é simples, nem fácil de ser administrada. Estar bem financeiramente é condição necesssária, mas não suficiente, para o clube vencer campeonatos. Aparentemente trata-se de ações complementares, o que em parte procede; todavia, nem sempre isso acontece. O clube mais rico não é campeão automaticamente nem com a frequência que seria razoável pressupor. Além disso, o fato de um clube estar bem econômica e fianceiramente não implica a exclusão de outros no mesmo patamar. E quando os títulos de um clube rico não vêm, o clamor da torcida é ainda maior e ocorre com agressividade intensa, pressionando dirigentes, causando impacto na imprensa, ocasionado relação tensa com os atletas.

$\mathrm{Na}$ missão dos clubes de futebol profissionais, sobretudo os mais tradicionais, há convivência e choque entre os objetivos primários do esporte como fonte de prazer e exercício da relação afetiva entre torcedor-clube do coração e as imposições naturais do negócio-futebol, do "business" - as requisições da indústria do entretenimento, a busca por eventual lucro por parte dos acionistas que 
suportam o negócio. E o que agrava mais o cenário é a forma descuidada, amadora, nada impessoal, primitva, como muitos clubes, no Brasil, são administrados. Diante de um desafio tão complexo que é administrar tal dicotomia, a forma de gestão exponencializa os riscos de insucesso e frustração.

LEONCINI (2001) destaca:

\begin{abstract}
"No cerne desta evolução do campo esportivo estão as lutas que disputam o monopólio de imposição da definição legítima da prática esportiva e da função legítima da atividade esportiva: amadorismo contra profissionalismo, esporte-prática contra esporte-espetáculo, esporte de eleite e esporte popular. Mais recentemente, a luta principal travada no interior ddo campo é a luta que disputa gestão e o controle do esporte profissional: gestão amadora ou política contra gestão profissional, clube social contra empresa profissional."
\end{abstract}

Além de desafio de tal porte, como o da gestão competente para defrontar o problema, há uma carga pouco pensada, pouco aprofundada, no estudo desse caso: o romantismo acalentado por muitos torcedores, principalmente os mais antigos, que viveram a fase semiamadora do futebol, e que é procedente, não pode ser descartada de pronto, como se tratasse de algo anacrônico e descartável "in limine”. Em GALEANO (1995), “ a história do futebol é uma triste viagem do prazer ao dever. Ao mesmo tempo em que o esporte se tornou indústria, foi desterrando a beleza que nasce da alegria de jogar só pelo prazer de jogar".

Não é possível abraçar tal sentimento integralmente diante da realidade da economia do futebol; também não cabe menosprezá-lo, por estar na origem do vínculo afetivo do torcedor e na relação social que o sustenta, imprescindível para a consolidação dos clubes. O segredo, no caso, é a devida ponderação.

E o caminho para isso é o que procuramos aprofundar no presente capítulo. O certo é que o Allianz Parque na Economia do futebol foi o modelo com mais êxito para o estudo e alcance da possibilidade de consecução de tal objetivo.

Não se trata tão-somente de encontrar uma solução pontual para 0 problema. O Allianz Parque e o que discorremos no trabalho rumam na direção de 
perceber um caminho estável e permanete, fugindo do hábito brasileiro de soluções imediatistas, que não se sustentam ao longo do tempo nem se reproduzem. É a investigação em torno do estabelecimento de um ambiente propício, que não se esgote em caso exemplarmente excepcional. Aliás, o desenvolvimento desse ambiente é bem tratado por CASTRO E MANSSUR no livro Futebol, Mercado e Estado:

\footnotetext{
"Ao contrário: ele lida com um fenômeno estrutural, fruto de décadas de incapacidade de criação de soluções efetivas para formação, manutenção e desenvolvimento de ambiente propício para gestão de atividade que deixou de ser essencialmente lúdica e amadora. Aí reside o divisor de águas. Enquanto o futebol foi tratado em plano mundial, com as devidas características e peculliaridades, como atividade não empresarial, sem uma organização compassada com essa faceta, o Brasil, estimulado pelo mito do "jeitinho" e da ufanista máxima da habilidade natural e incompatível de seus jogadores, protagonizou o cenário futebolístico. Mas, o amadorismo, em outros centros, cedeu posição a um sistema organizado e profissional, ora mantendo-se fiel ao modelo associativo, mas, em qualquer caso aderente à realidade (i) do fluxo informacional, negocial e de capitais, bem como (ii) das técnicas contemporâneas de governação societária."
}

Conjugar mercado e sonhos não é fácil, mas é possível. Seguramente o caminho não é o trilhado no Brasil pela maioria dos clubes, e a Sociedade Esportiva Palmeiras conquistou essa oportunidade através da emergência do Allianz Parque. O primeiro desafio é o modelo de governaça da matriz econômica.

\subsection{O Antagonismo Formal e os Modelos de Governança}

O Brasil vive sob a égide do antagonismo formal, que consiste na aplicação de duas forças sobre o mesmo objeto, uma progressista, "modernizadora", que o elevaria, e outra antiquada, arcaica, voltada a um conservadorismo praticamente primitivo, que o descenderia. A resultante não nos permite grande desenvolvimento, ascensão significativa, nem nos submerge rigorosamente. $O$ fato de não nos remeter a retrocesso profundo, em certas ocasiões, impede um choque 
de arcaísmo que nos levaria à reação vigorosa contrária, recuperando o tempo perdido. $\mathrm{O}$ antagonismo formal nos retém em zona mediana, consagrando a mediocridade. A consequência se apresenta numa frase atribuída a Mário Henrique Simonsen: "O Brasil não confirma nem os melhores nem os piores vaticínios".

É muito difícil que o Brasil se eleve ao patamar que necessita para alcançar a trajetória de um país desenvolvido econômica e socialmente, diminuindo a iniquidade acentuada que $\mathrm{o}$ distingue e nos constrange.Esssa barreira do antagonismo formal está ancorada em diversos fatores culturais, históricos e da formação econômica do país, afetando todas as atividades, abrangendo o futebol.

A ação do antagonismo formal estabelece o rito da parcialidade, da submeta. Nada avança nem retroage de forma considerável, produzindo movimentos incompletos, fracionados, sob os signos da instabilidade e da insuficiência.

Florestan Fernandes tratou desse fenômeno onde duas forças antagônicas incidem sobre a mesma matéria denominando-o "capitalismo dependente". Em artigo elaborado por Giuliano Contento de Oliveira e Daniel Arias Vasquez, "Florestan Fernandes e o capitalismo dependente: elementos para interpretação do Brasil"99, os autores descrevem o pensamento de Florestan:

\footnotetext{
"A depender do tipo de reação, as estruturas coloniais serão ou não internamente suplantadas pela ordem social competitiva emergente: quando totalmente suplantadas, originam economias autossuficientes e economicamente autônomas, quando parcialmente superadas originam o capitalismo dependente, sistema em que a ordem social competitiva interage com as estruturas arcaizantes produzindo economias polarizadas, heterogêneas e incapazes de espraiar as forças modernizadoras ao conjunto da sociedade". (OLIVEIRA; VASQUEZ, 2010, p. 148).
}

O processo de antagonismo formal aparece em vários momentos da história política, econômica e social do Brasil desde a colônia. O futebol brasileiro não foge à regra, e desde seu exórdio em nossa terra combina simultaneamente forças modernizantes e arcaicas.

${ }^{99}$ OLIVEIRA; VASQUEZ. Florestan Fernandes e o capitalismo dependente: elementos para interpretação do Brasil. Rio de Janeiro. Revista Oiko, 2010. 
O semiamadorismo, aplicado a partir de 1930, representou uma de suas primeiras manifestações, ao justapor movimento de revolta dos clubes contra diretriz que procurava coibir o profissionalismo dos atletas, denegando o pagamento de salários permanentes. Contrapunha medidas de caráter paternal, personalistas, eivadas de insidioso mecenato, que mantinham os clubes sob 0 comando dos mesmos agentes arcaicos, pseudomodernizadores.

O antagonismo formal acompanhou nosso futebol de forma muito semelhante ao processo de desenvolvimento do país, ora de modo explícito, escarrado, ora de forma dissimulada, disfarçada, mas, sempre como fator a obstaculizar seu progresso, que por muitas vezes, parecia iminente, todavia, frustrado imediatamente pela reação produzida em sentido contrário.

O raio de ação dos agentes verdadeiramente modernizadores não logra envolver o todo da organização do futebol, nem da respectiva economia, restringindo-se a certas esferas administrativas e financeiras, sendo incapaz de contemplar o conjunto almejado. Imagem icônica desse antagonismo foi a capa da revista "The Economist"100, em 2009, que exibia o Cristo Redentor, símbolo do Rio de Janeiro e do Brasil, como um foguete pronto a decolar, vaticinando que o país tangenciava o futuro promissor tantas vezes anunciado. Meses depois mergulhávamos na maior recessão da nossa história.

Poucos sabem que entre 1933 e 1937 existiram duas entidades com autoridade sobre o futebol brasileiro: a Confederação Brasileira de Desportos CBD e a Federação Brasileira de Futebol - FBF, por conta das visões diferenciadas com relação ao profissionalismo. Havia duas forças atuando no futebol, uma arcaica, buscando impedir a profissionalização; outra modernizante, procurando consolidá-lo.

Marcelo Proni, em A Metamorfose do Futebol ${ }^{101}$, descreve com propriedade:

"No RJ, o movimento de criação de uma liga profissional foi liderado pelo Sr. Oscar da Costa, presidente do Fluminense (curiosamente o clube mais tradicional da época), que se opunha à direção política da AMEA,

100 The Economist. Brasil takes off. Londres, 2009.

101 PRONI. A Metamorfose do Futebol. Campinas. Ed. Unicamp, 2000. 
presidida por Rivadávia Meyer, do Flamengo. Depois de muita discussão, Fluminense, América, Vasco e Bangu criaram a LCF, Liga Carioca de Futebol, em histórica assembleia de 23 de janeiro de 1933. Em São Paulo, a transição foi menos traumática: após a extinção do futebol no Paulistano, em 1929, apenas Santos e Ponte Preta permaneciam contrários ao profissionalismo. Diante da expectativa carioca, a APEA adotou oficialmente o futebol profissional em 3 de março de 1933". (PRONI. 2000)

Venceu a modernização, mas de 1933 a 1937 remanesceu a cisão, a obstaculizar o desenvolvimento do profissionalismo. Isso repercutiu não só na prática esportiva, contemplando a escolha dos jogadores que comporiam o selecionado brasileiro que atuaria na Copa do Mundo da Itália, em 1938.

Em 1937, a CBD negociou com os componentes da FBF, cedeu reconhecendo o profissionalismo e voltou a ser a única representante do esporte no Brasil. Mais recentemente, o antagonismo formal no futebol tem se manifestado nos movimentos para a introdução de modelos de gestão nos clubes de futebol mais tradicionais e com maior número de torcedores.

O São Paulo Futebol Clube alterou o Estatuto Social para criar uma presidência menos centralizadora, personalista e autocrática. Introduziu um Conselho de Gestão que atua junto à presidência, com nove membros, e que deveria contemplar a presença de três membros vindos do mercado profissional, executivos com experiência em administração, para agregarem conhecimentos novos ao ambiente político interno visando impedir a "politização endógena". Com celeridade, transformaram os nove membros que deveriam trazer os ares externos em conselheiros, ligados ao presidente, mantendo a força política dos grupos internos de poder, sopesando o modelo anterior, antiquado, que deveria, por diretriz do novo estatuto, ser erradicado. O mais comum é que todo movimento na direção de gestão mais moderna seja sopitado por arranjos administrativos contrários.

No Santos Futebol Clube, depois de muitos anos de poder centralizado e personalista, o presidente Luís Álvaro de Oliveira Ribeiro ${ }^{102}$, empresário e ex-chefe de Gabinete do Ministério da Fazenda na gestão Bresser Pereira, e neto do ex-

102 Luis Álvaro de Oliveira Ribeiro, também conhecido como LAOR, foi um empresário brasileiro do setor imobiliário e presidente do Santos Futebol Clube, tendo cumprido mandato entre dezembro de 2009 e maio de 2014. 
presidente Luís Álvaro de Oliveira Ribeiro, elegeu-se em 2009, com a plataforma explícita da modernidade.

Implantou um Conselho Gestor que preencheu com a nomeação de profissionais do mercado, sobretudo do mercado financeiro, para imprimir uma nova sistemática na administração do clube. O Conselho deveria ter profissionais das áreas mais relevantes como Finanças, Marketing, Administração, que cuidariam das diretrizes estratégicas dos respectivos setores, em contato com os profissionais executivos contratados para tais áreas, dinamizando e trazendo ventos novos às estratégias e ao caminho desses executivos. Com o tempo, o Conselho Gestor foi espraiando suas competências, seus membros passaram a ser pessoas da confiança do presidente para assegurar que as decisões dele prevalecessem. Hoje, o Conselho tem um papel de gestão operacional no dia a dia, dificultando e obstaculizando 0 trabalho dos gerentes e executivos. A modernização recuou, o seu efeito foi amenizado a princípio, e hoje a medida tem várias consequências negativas como a insubsistência dos profissionais contratados e as falhas em contratos relevantes como ocorreu com a transferência do conhecido atleta Neymar para o Barcelona.

Se isso é uma realidade na vida do país, ocorre de modo mais veemente e pronunciado no futebol, por este estar embasado em estruturas antigas como as federações estaduais, que se sustentam por intermédio do refreamento da modernização, acima de tudo em curso na Europa, não permitido a adoção de um calendário compatível com o do resto do mundo.

Trata-se, portanto, do antagonismo formal, nascido com propriedades bastante semelhantes ao capitalismo dependente referenciado por Florestan Fernandes. Ao introduzir o conceito de capitalismo dependente, Florestan, em a Revolução Burguesa no Brasil (1975) ${ }^{103}$, observa, conforme o artigo de Giuliano de Oliveira e Daniel Vasquez:

"A constituição do Estado (Brasileiro) amálgama decorreu de um impasse histórico que se colocou ao processo de afirmação autônoma das elites no Brasil, que ao mesmo tempo que exigia o rompimento da condição de colônia, não permitia a gestão democratizada de poder. O privilégio em

103 FERNANDES. Revolução Burguesa no Brasil. Ed. Zahar, 1975. 
escala nacional, subproduto do monopólio do poder político pelos estamentos senhoriais atuava na direção de preservar e fortalecer as estruturas socioeconômicas nas quais repousavam o prestígio social exclusivo dessa classe. Não obstante, a implantação de um Estado nacional independente lançaria as bases para a formação do chamado "Brasil moderno", ainda marcado por contrastes sociais e econômicos, agudos que configuram a sua dualidade estrutural." (FERNANDES, 1975).

Mutatis mutandis, a construção é semelhante. O que representaria a "burguesia" no futebol são os dirigentes de federações e da maioria dos clubes. Eles foram ascendendo, inclusive socialmente, no exercício dos cargos, e construíram uma estrutura controlada de poder, junto com a "aristocracia", os dirigentes da CBF, de modo a não serem apartados dele, e só permitirem o ingresso no respectivo círculo aos que os apoiam e propugnam pela manutenção do status quo. Criaram um sistema impessoal e burocrático, tornaram-se "homens de negócio", via federações, clubes, CBF e órgãos de apoio, transformando os clubes em empresas sustentadas pelo modelo, que se funda em reter indefinidamente os ativos que irrigam os recursos financeiros do futebol.

Para avançarem precisaram, por vezes, irromperem modernidade adentro na obtenção de resultados financeiros mais expressivos que garantissem o financiamento do sistema, para não serem apeados do poder, como Florestan Fernandes registrou sobre a formação da burguesia nacional e a necessidade de extinção dos laços com o Brasil Colônia. Porém, para não perderem os privilégios de comando, sempre que contemplaram ações modernizadoras aplicaram simultaneamente mecanismos ultrapassados de administração, tolhendo o processo necessário.

O antagonismo formal é um fenômeno decisivo no entendimento do insucesso da consolidação de um modelo de gestão sustentável e autônomo nos clubes de futebol do Brasil, é fenômeno complexo, tão profundo quanto sutil, raramente observado na crítica que se faz à instabilidade financeira dos clubes. Ele ainda não aflorou para o mundo do futebol com a importância devida na história econômica do esporte. 
Apresentou-se mais recentemente no episódio sobre a introdução do árbitro de vídeo, o vídeo-árbitro ${ }^{104}$ (VAR, na sigla em inglês), quando após uma reação clamorosa na mídia por conta de um gol feito com a mão pelo atacante Jô do Sport Club Corinthians Paulista contra o Clube de Regatas Vasco da Gama, pelo campeonato Brasileiro de 2017. A CBF decidiu, tangida pela revolta opinião pública, a introduzir o mecanismo eletrônico. Anunciou que iria implementá-lo de uma semana para a outra, em atitude açodada diante das exigências técnicas do sistema. A seguir percebeu a inviabilidade, em prazo tão curto, foi levando o assunto sem conclusão, e, meses depois, ao discuti-lo no Conselho Arbitral, que referendou as regras do campeonato de 2018, utilizou estratégia para derrubar a introdução do vídeo-árbitro que a mesma CBF defendeu. Procurou não desagradar os clubes que se julgavam incapazes de arcarem com os respectivos custos. A CBF sequer cogitou a possibilidade de financiá-los, que teria papel modernizador, ao tornar o futebol em espetáculo mais técnico e justo. Em todos os centros desenvolvidos do futebol mundial o vídeo-árbitro está sendo incorporado de alguma forma e tem proporcionado espetáculos mais atraentes, valorizando a excelência em detrimento da manipulação e do "jeitinho" que procura levar vantagem indevida através da elisão de atos anti desportivos. Ele foi introduzido no ampeonato de 2019, por ação das forças midernizadoras, porém, com vários aspectos negativos, sobretudo no cumprimento do protocolo estipulado pela FIFA. Nem deixou de ser utilizado, nem surtiu o efeito imaginado.

A Sociedade Esportiva Palmeiras, personagem central desse trabalho, também tem exemplo hodierno do antagonismo formal, ao tratar da gestão de todos os recursos abundantes que passou a ter com a construção e utilização do novo estádio. Buscou criar estrutura profissional de gerenciamento com executivos contratados junto aos respectivos mercados, ganhando salários relevantes. Colocou-os, todos, sob o comando de diretores estatutários, a grande maioria

104 O sistema do vídeo-árbitro está a ser introduzido no futebol para apoiar as decisões do árbitro principal. Este sistema tem a função de ajudar a corrigir decisões claramente erradas em momentos-chave do jogo, bem como em situações graves que tenham passado despercebidas à equipa de arbitragem. 
conselheiros que não podem receber remuneração e que nem sempre dispõem da formação técnica aprofundada exigida para liderar os profissionais citados. Entre diretores e subdiretores o Palmeiras Há cerca de 100 conselheiros, de um total de 280, que definem o que os profissionais devem fazer, e, em quadro semelhante aos citados exemplos do São Paulo Futebol Clube e Santos Futebol Clube, com seus respectivos conselhos gestores, trazem para a gestão todas as escaramuças e consequências da vida política interna, reduzindo a eficácia do processo. Os conselheiros não atuam nem deliberam conforme avaliação técnica racional e objetiva dos resultados, mas tangidos predominantemente pela política interna do clube. O sucesso econômico de 2018 se transfomou em amargo pesadelo em 2019 com crescimento significativo da dívida e um fluxo de caixa negativo.

O Sport Clube Corinthians Paulista não foge à regra e os clubes do Rio de Janeiro, mesmo o Clube de Regatas do Flamengo, o mais avançado no estado, com ações gerenciais com êxito reconhecido, também não escapa desse antagonismo formal onde a forma de administrar o poder das instituições por intermédio de suas estruturas de comando mistura amadorismo com profissionalismo, paixão com processo racional, interesses pessoais e de política interna com modernos arcabouços organizacionais. Recentemente, após vencer o campeonato Brasileiro e a Taça Libertadores da América, chegando com méritos ao Mundial de Clubes da FIFA, protagonizou episódio amador e inexplicável na demissão do diretor de futebol Paulo Pelaípe, integrante da equipe que logrou os resultados mencionados. A questão não foi a dispensa em si, mas a forma como se procedeu, antagonizando o Flamengo moderno, campeão, rico, do Flamengo arcaico anterior que voltou a se apresentar.

A emergência do antagonismo formal é crucial no deslinde dos obstáculos ao modelo específico que pesquisamos, e que entendemos ter o poder de se tornar face diferenciadora para a constituição da matriz econômica sustentável para os clubes de futebol no Brasil. O antagonismo formal, hoje, mais proeminente é a contradição entre o que os presidentes de clubes que apregoam ser modernizadores anunciam e o comportamento que exercem junto à CBF e às 
federações estaduais. Os votos que enunciam, os procedimentos políticos diante da fixação de diretrizes desses órgãos de administração do futebol colidem frontalmente com o que defendem para os clubes. E como essas organizações dependem das normas e ações implementadas pelas federações e CBF, essa incidência de duas forças em sentido contrário, anulam vários esforços, amenizam outros, provocando um deambular infrutífero, que oscila constantemente, nunca proporcionando um patamar destacado, salvo escassas exceções. Essas excepcionalidades acontecem quando a força modernizadora é muito potente e logra arrastar o objeto para níveis superiores, mesmo que não o faça com a dimensão que seria possível se a força arcaica não estivesse interagindo.

Em 17 de junho, data da estreia do Brasil na Copa da Rússia, a Folha UOL trazia uma matéria instigante a ilustrar o cenário do antagonismo formal em curso: "Tite obteve liberdade total da CBF para estruturar o projeto do hexacampeonato"105. E para isso, lançou mão de todos os recursos e ferramentas modernos, da mais avançada tecnologia existente, não deixando o Brasil dever a nenhuma outra potência do futebol mundial com tradição gerencial como a Alemanha. Aumentou o número de assessores, procurando contemplar todas as áreas de trabalho com dedicação integral dos especialistas chamados, em suma, voou ao cume da modernização, sem limitações e, se vencesse o campeonato, teria como chefe imediato o presidente da CBF, que nem é mais Marco Polo Del Nero ${ }^{106}$. O presidente que teria conquistado o almejado hexacampeonato, perseguido há dezesseis anos com três insucessos anteriores, inclusive o fracasso constrangedor da Copa no Brasil, seria o Cel. Nunes, um coronel da PM do Pará, que presidiu a federação local sem brilho e sem mostrar qualquer intimidade com o futebol, e que protagonizou na assembleia que escolheu o local da Copa do Mundo de 2026, papel inimaginágel, ao votar com Marrocos, após ter se comprometido, como todos os presidentes de confederações do continente americano o fizeram, em escolher os EUA, México e Canadá, como anfitriões. Mas, não foi só o voto na direção contrária ao estabelecido e nem contra uma Copa proposta com mais

105 Site: https://www.bol.uol.com.br/copa-2018/noticias/2018/06/17/caos-politico-deuliberdade-inedita-a-tite.htm.

${ }^{106}$ Marco Polo Del Nero foi presidente da Confederação Brasileira de Futebol - CBF de 2015 a 2018. 
modernidade do que o Marrocos pretendia, além da forma como procedeu, a motivação, o comportamento pessoal e o conteúdo das declarações, como também o modo pelo qual administra a CBF, vão de encontro frontal ao trabalho de Tite, atual treinador da Seleção Brasileira de futebol.

O técnico que poderia ser o campeão seria modernizador, o presidente que ostentaria o título historicamente é conservador e reacionário. E indica em todos os movimentos realizados, que continuará assim. Posteriormente, em 2018 e 2019, o "modernizador" Tite não se incomodou de , após contratar o filho para a Comissão Técnica como analista de dados, depois torná-lo sem qualquer experiência anterior como treinador, em auxiliar-técnico oficial e braço direito, retornando ao modelo personalista que não convive com a modernidade que Tite dizia perseguir.

Se lançarmos um olhar ao passado e procurarmos trazer para o presente 0 que se enxerga factualmente na gestão da CBF, veremos uma sucessão de movimentos contraditórios funcionando simultaneamente sobre a organização do futebol brasileiro. Um dos símbolos mais vivos foi a CBD, precursora da CBF, em 1937, realizando acordo com a entidade dissidente, a Federação Brasileira de Futebol, em episódio relatado em capítulo anterior.

A CBF induz a não implantação do VAR em 2018 e o adota em 2019, tendo os mesmos recursos que justificou para não tê-lo, e o faz de modo estouvado, sem preocupação com os resultados. O antagonismo formal vigente no país é um grande desafio para a matriz econômica que buscamos investigar nesse trabalho e se soma ao enorme repto que o fator humano acarreta no futebol brasileiro. Como a condição humana influi no processo.

\section{3. $O$ fator humano na gestão do futebol}

Os livros, trabalhos, artigos e reportagens sobre gestão e administração do futebol brasileiro, embora não sejam abundantes, escrutinam com eficiência os modelos estruturais que impediram ou ainda impedem a estabilidade econômica dos clubes, e alguns deles discutem com propriedade o que deve ser feito na direção do modelo eficaz. 
Marcelo Proni realiza uma boa discussão em "A Metamorfose do Futebol", utilizando como ponto de referência os artigos de Matinas Suzuki na Folha de São Paulo, de 1998, que tratavam da modernização do futebol. Em sua tese "EsporteEspetáculo e Futebol-Empresa"107, PRONI (1998) também investiga com cuidado o processo, e ambos, ele e Matinas, trazem para a realidade da época, alternativas fundamentadas. Ocorre, porém, no cenário constatado durante o trabalho de pesquisa, o fator intangível, representado pela condição humana, no caso, pelo comportamento pessoal dos dirigentes, a combinar personalidade e idiossincrasias. A amalgamar persona, sombra e si-mesmo. Penso que os fatores intangíveis nunca foram considerados com a importância que deveriam ter ou foram sumariamente descartados da análise, desprezando-se elemento relevante no resultado da gestão. No caso, a formação, os valores a se refletirem na conduta dos dirigentes

É natural que em arcabouços idênticos de governança, a personalidade do dirigente imponha diferenças. Isso acontece em empresas com sólidas estruturas de administração, mesmo com aspectos de impessoalidade rígidos e várias instâncias decisórias que ampliam a rede de participantes nas definições das diretrizes gerenciais, porém, no futebol, por toda sua natureza desregrada e influências passionais, os desvios do padrão organizacional implicam diversificações mais amplas e aprofundadas, que precisam ser estudas com mais atenção.

Os presidentes de clubes conseguem moldar a seus respectivos talantes, mesmo as estruturas formais existentes, muitas vezes manipulando os órgãos de gestão e os poderes políticos estabelecidos, como os conselhos deliberativos e fiscais, modificando a praxe, a ponto de ela funcionar em completa oposição ao que ocorria com o seu antecessor. $O$ espaço nos clubes de futebol franqueado ao manejo do processo de governança é muito maior do que nas estruturas empresariais que lidam com os mesmos volumes de receitas e de orçamentos. Os clubes mais tradicionais do país trabalham com orçamento de centenas de milhões de reais por ano, possuem centenas de funcionários, o que significa no padrão

107 PRONI, Marcelo Weishaupt. Esporte-Espetáculo e Futebol-Empresa. 1998. 275 f. Tese (Doutorado em Educação Física) - Faculdade de Educação Física, Universidade Estadual de Campinas, Campinas, 1998. 
brasileiro " empresa de grande porte". Empresas dessas dimensões de faturamento e de empregados impõem rigor muito maior à discricionariedade dos seus dirigentes e executivos. Por não se suceder nos clubes, a diversidade suscita cenário bastante específico, fazendo com que o comportamento do dirigente influa mais decisivamente no resultado. Os Conselhos Deliberativos, a quem caberia a fiscalização das atitudes e atos administrativos tem entre seus mebros número elevado de diretores que, concomitantemente, são juízes e réus, são atores e críticos das ações, afastando qualquer possibilidade de ação corretiva e saneadora consistente, salvo honrosas exceções que confirmam a regra.

Corremos o risco de condenarmos ou consagrarmos o modelo que leva a matriz que investigamos e que se sucedeu no Palmeiras indevidamente, sem que ele seja observado por esse ângulo do comportamento, por nos limitarmos puramente a técnica ou só nos basearmos em resultados de curto prazo. A qualidade pessoal do dirigente, a sua forma de condução, no caso, podem mudar o resultado, e muito. Pode-se dizer: a qualidade do jogador altera o placar. Os presidentes Paulo Nobre e Maurício Galiotte, oriundos do mesmo grupo político tiveram procedimentos absolutamente antagônicos no trato da mesma matriz.

Por muito tempo, a história do pensamento administrativo registra, que os responsáveis por analisá-la menoscabaram a relevância do comportamento humano, tanto na base, os empregados, quanto na cúpula, os dirigentes. Por muitos anos, filósofos e pensadores cuidaram de alertar os administradores para as respectivas responsabilidades com relação ao aspecto social.

Claude S. George Jr., em "História do Pensamento Administrativo"108, escreveu:

"O processo de tomada de decisões passou, igualmente, por várias mudanças, no decorrer do tempo. Ao que parece, nos primeiros tempos, os administradores tomavam suas decisões baseados em grande parte, em palpites, intuição e conjeturas".(GEORGE Jr.,1974).

Isso mudou, em parte, nas empresas, mas no futebol brasileiro, quase nada. Os dirigentes, mesmo contemplados com arcabouços organizacionais modernos e

108 GEORGE JR.Claude S. História do Pensamento Administrativo. São Paulo, Cultrix, 1974. 
tecnicamente bem constituídos, resvalam sistematicamente para o abismo dos palpites, intuição e conjeturas.

Em parte, esta tese procura desvelar a história do pensamento administrativo no futebol brasileiro e, ao fazê-lo, busca a emergência dos fatores preponderantes na condução dos clubes, e que, por não serem usuais na gestão das empresas, quedam submersos e desconsiderados.

Como já nos referimos acima, compondo um mesmo grupo político, atuando sob as mesmas diretrizes organizacionais, contando com muitos diretores comuns às duas gestões, respeitando idênticas normas e composições dos conselhos, Paulo Nobre e Maurício Galiotte realizaram gestões bem diferentes, cada qual moldada às respectivas características pessoais, personalidades e idiossincrasias não só em aspectos em que a decisão assume caráter mais personalizado, mas também, e com muito mais impacto, em assuntos onde se esperaria um padrão mais técnico e impessoal, como a negociação dos direitos de transmissão por TV, a forma de lidar com a dívida do clube e a relação com o patrocinador mais relevante.

Assim também ocorreu no Corinthians com Andrés Sanchez, Mário Gobbi e Roberto Andrade, todos integrantes, na origem, de um mesmo grupo político e governados pelas mesmas diretrizes administrativas e normas estatutárias, perpetrando gestões bem diferentes, sob a égide do mesmo modelo organizacional.

No São Paulo Futebol Clube, com Juvenal Juvêncio, Carlos Miguel Aidar e Carlos Augusto de Barros e Silva . No Santos Futebol Clube com Modesto Roma Jr. e José Carlos Péres ${ }^{109}$, e em tantos outros clubes que poderiam ser citados, 0 mesmo procedimento de antagonismo se revelou sem que houvesse uma troca nos agrupamentos pol'ticos dos dirigentes em exercício.

$\mathrm{Na}$ realidade, como sempre acontece, ao nos defrontarmos com problemas cruciais, dá-se prioridade ao que é menos desgastante emocionalmente para ser tratado. O que, em regra, é cuidar de modelos administrativos, arcabouços

109 José Carlos Péres é o atual presidente dos Santos Futebol Clube. 
jurídicos, cuidar de estrutura teórica para propor mudanças, muito mais cconfortável do que arrostar as dificuldades advindas do comportamento dos dirigentes, que são negligenciadas, por se tratar de tarefa complexa a ser investigada. Portanto, há pouco material disponível para pesquisa, que tentaremos escrutinar por intermédio das observações fáticas, e de outros meios de investigação.

Niccolò di Bernardo dei Machiavelli, ou Nicolau Maquiavel, escreveu o célebre livro "O Príncipe"110, onde tratava do ser humano da forma como ele é, e não de como deveria ser, trazendo à discussão a ingente tarefa de administrar as pessoas e suas particularidades, sendo sua obra bastante conhecida. Outro grande especialista, o Brâmane Vishnugupta Kautilya ${ }^{111}$, que exerceu papel fundamental no Império Indiano durante o século IV a.C., em sua principal obra Arthashastra ${ }^{112}$, escrita em torno de 321 a.C., tratou também da ciência da administração política, que é mais próxima da administração de clubes de futebol do que a de administração de empresas. Kautilya, cuidou das questões políticas, econômicas e sociais do Estado com o objetivo precípuo de analisar as práticas que levariam ao êxito da administração, mostrando o que os homens estão acostumados a realizar e não o que "deveriam fazer". Ambos, Maquiavel e Kautilya se perpetuaram como sinônimos de figuras inescrupulosas, manipuladoras, maléficas, porque ao apresentarem o ser humano para si mesmo, como ele é, causaram rejeição e até repulsa, pois a sociedade evita se enxergar no espelho. É pungente se mirar sem o véu do autoengano. Por isso, os aspectos da personalidade humana envolvidos na administração tendem a ser obnubilados e esquecidos. Como o futebol traz em si o signo do entretenimento, da diversão, da alegria do jogo, e os críticos, em regra, são mais apaixonados do que analistas, mais torcedores do que críticos, e não buscam o distanciamento do objeto para o relatarem, eles descartam em grande escala, e com maior avidez, a condição humana envolvida na administração. O que

110 MAQUIAVEL, Nicolau. O príncipe (Trad. Antonio Caruccio-Caporale). São Paulo: L\&PM Editores: Porto Alegre, 2011.

111 Cautília, Kautília ou Kautilya, também chamado de Chanakya ou Vichnugupta, foi um estadista e filósofo indiano dos séculos IV e III a.C. que serviu como primeiro-ministro de Chandragupta Máuria, o fundador do Império Máuria.

112 Artaxastra, Artasastra ou Arthashastra (AITS: Arthaśāstra) é um antigo tratado indiano sobre estadismo, política econômica e estratégia militar escrito em sânscrito. Seu autor é Cautília (Kauțilya). 
desejamos alertar é a necessidade de se inserir na avaliação do modelo de gestão, que leva à matriz econômica de independência financeira, é a importância da atitude do dirigente, sobretudo do dirigente máximo que comanda o modelo.

Em 1987, quando da Copa União, momento em que os clubes assumiram excepcional e surpreendentemente a organização do campeonato nacional diante da desistência da CBF, que alega não dispor de recursos para sustentá-lo, formouse o chamado Clube dos 13 , com os 12 clubes mais tradicionais do Brasil e a inclusão do Esporte Clube Bahia, a convite dos outros 12, para representar o Nordeste do país. Diante do impasse, trataram de buscar financiamento e acabaram por conseguir um patrocínio integral da empresa americana Coca-Cola. Foi um processo complexo, mas dentro do prazo cabível para o início do campeonato, percorrendo momento crucial, no qual o Grêmio, rival histórico do Internacional, que tem a cor vermelha como marca, alegou que em seu estatuto havia a proibição do uso dessa cor na sua camisa. A Coca-Cola teria sua marca mundialmente conhecida com fundo vermelho estampada em todas as camisas dos participantes, mas o Grêmio intestou o fato, que se cingia à questão técnica de patrócínio, que naquele momento salvava o fracasso do campeonato, pela não existência de condições por parte da CBF. Foi preciso consultar a sede da empresa em Atlanta, que levou horas para reunir seu conselho de administração e permitir, na única exceção da sua história até então, que o Grêmio utilizasse a cor preta no lugar da vermelha no logotipo oficial. Superado esse obstáculo que parecia instransponível, assegurando patrocínio que evitava o vexame incomensurável do futebol brasileiro, ao não efetuar um campeonato nacional naquele ano, no momento em que haveria a assinatura com conexão direta com Atlanta, Vicente Matheus, presidente do Corinthians se nega a assinar. $E$ se faltasse qualquer assinatura o contrato não entraria em vigor, conforme as normas estabelecidas. Diante de todos os outros clubes esperando pela salvação da arrecadação do ano, porque sem o patrocínio a TV também não pagaria sua parte, Vicente Matheus, então presidente do Corinthians, recusou-se peremptoriamente. Matheus era um homem simples, que enriquecera como dono de pedreiras, duro, seco e pouco letrado, dotado de personalidade fortíssima, 
teimosia inarredável.Perguntaram-lhe o porquê da negativa e Matheus respondeu: "porque se é bom para o São Paulo não é bom para o Corinthians, o São Paulo nos tirou o Renatinho (jogador da base) e eu não perdôo". Todo o empreendimento correu o risco de fracasso avassalador por conta da personalidade do dirigente, sem que houvesse qualquer cláusula ou norma que impedisse que UM dirigente tão-somente pudesse provocar um prejuízo moral e financeiro imenso aos clubes. Foi necessário mais um bom tempo para convencê-lo, permanecendo todo o mundo do futebol e Atlanta, atônitos e inertes, por conta da personalidade do expresidente corintiano, em instante em que os clubes fechavam o maior contrato, até então, e que acabou por levar ao campeonato que estabeleceu recorde de público e renda por muito tempo na história do nosso futebol.

Tabela 45 - Público e renda recorde de 1987, 1988, 1999 (em milhões Cz\$)

\begin{tabular}{|c|c|c|}
\hline Ano & Público Total & Renda \\
\hline 1987 & 4.989 .603 & 2.226 .700 \\
\hline 1988 & 4.005 .190 & 6.605 .255 \\
\hline 1999 & 4.005 .700 & 7.454 .590 \\
\hline
\end{tabular}

Fonte: Uol Esporte - https://www.uol.com.br - acesso em 16/05/2019, Galo Digital http://www.galodigital.com.br/ acesso em 17/05/2019.

Não foi um lance pontual, apenas midiático, que exemplifica tantos outros que acontecem nos bastidores do futebol, a evidenciar o peso da atitude do dirigente no processo de consecução de modelo organizacional sustentável para os clubes brasileiros.

A atitude, por intangível, não há como ser mensurada da mesma forma que ações objetivas como receitas financeiras, todavia, cabe inseri-la no processo de medição da eficácia do modelo, o que buscaremos fazer no capítulo adiante dedicado a isso. A avaliação do modelo não pode se isentar de incluí-lo na análise, e cremos que tal omissão tem prejudicado significativamente à evolução para a estrutura colimada. 
Modelos são estruturas criadas para representar da melhor forma possível a realidade, e, em geral, encontram dificuldades para interpretar as ações humanas subjetivas, contudo, nada tem obstado o aprimoramento desses modelos, como ocorre com frequência na ciência econômica, sobretudo na econometria. As equações gerais, e básicas, de Kalecki e de Keynes, que visam a explicação sobre o crescimento econômico suscitado pela demanda efetiva, partem de propostas teóricas e fechadas, para depois incorporarem a incerteza humana contida inexoravelmente na luta por meios de sobrevivência e renda.

Por conta disso, Keynes alertou:

\begin{abstract}
"O que apenas desejamos lembrar é que as decisões humanas envolvem o futuro, sejam elas pessoais, políticas ou econômicas, não podem depender da estrita expectativa matemática, uma vez que as bases para realizarem semelhante cálculo não existem, e que o nosso impulso inato para a atividade é que faz girar as engrenagens, sendo que a nossa inteligência faz o máximo possível para escolher o melhor que pode haver entre as diversas alternativas, calculando sempre que se pode, mas retraindo-se, muitas vezes, diante do capricho, do sentimento ou do azar". (KEYNES).
\end{abstract}

Adicione-se a tal proposição, que sobreleva a importância do capricho humano nas decisões em contraposição à "matematização", ao impulso de se buscar soluções que envolvem o humano por meio de fórmulas, em consonância com o pensamento de Jung: "Não importa como as coisas são, mas sim como as vemos".

Os seres humanos, na formação do processo decisório, independentemente das diretrizes e normas que os envolvem no sistema, são tangidos fortemente pela forma como enxergam as coisas. Diante do mesmo objeto, o homem interpreta de modo diverso de outrem, de acordo com a sua visão de mundo, cultura e com a tendência da respectiva personalidade.

Os modelos de sustentação econômica possuem constituição teórica, porém, submetidos à prática exigem complemento inafastável que os conecte com a dinâmica do procedimento humano, a contemplar a bulha da vida, com todas as suas contradições. 
A omissão ou a depreciação do fator humano nos modelos econômicos e administrativos dos clubes de futebol têm proporcionado falha no processo de construção de modelos eficientes, que correspondam à complexa realidade humana, matéria que os pensadores Maquiavel e Kautilya se debruçaram, com alto preço às respectivas reputações, como vimos. $A$ atitude do dirigente conta, como já aludimos, ela altera o placar. No futebol, muito mais do que na empresa convencional.

O clima que envolve a sociedade em determinado momento atua diretamente no ser humano, fazendo-o tomar decisões e implementar ações que, em outras condições, mesmo com as mesmas convicções, personalidades e interesses, não realizariam. O ambiente faz brotar um conjunto de iniciativas que são propulsionadas pelo entusiasmo ou frustração dominantes e pela ideia motriz em vigor, que se juntam para formar o chamado "espírito do tempo". Este pode modificar, e seguramente influencia as atitudes humanas. O que estamos querendo dizer é que a personalidade do dirigente, com todo o poder que tem, e a inexplicável irresponsabilidade que goza pelo regime jurídico que a nossa legislação permite aos clubes, possibilitando que eles, apesar de exercerem atividade comercial incontestável e com valores significativos, na comercialização de ingressos, na compra e venda de jogadores, na contratação de patrocínios, possam atuar como entidades sociais sem fins lucrativos, nos moldes de clubes exclusivamente sociais.

Max Weber, em "A ética protestante e o espírito do capitalismo"113, explica o capitalismo com o que ele chama de sentenças de Benjamin Franklin, que Ferdinand Kürnberger, em o "Retrato da Cultura Americana", diz ser a confissão de fé do "yankee":

- Lembra-te que tempo é dinheiro;

- Lembra-te que crédito é dinheiro;

- Lembra-te de que o dinheiro é de natureza prolífica, procriativa;

- Lembra-te do refrão: "O bom pagador é dono da bolsa alheia";

113 WEBER M. A ética protestante e o espírito do capitalismo. 3 ed. Trad. de Irene de Q. F. Szmrecsáyi e Tomás J. M. K. Regis Barbosa Szmrecsáyi. São Paulo: Pioneira, 1983. 
- Lembra-te: as mais insignificantes ações que afetem o crédito de um homem devem ser consideradas. O som do teu martelo às cinco da manhã ou às oito da noite farão um credor que os ouvir, conceder-te mais seis meses de crédito.

- Guarda-te de pensar que tens tudo o que possuis e de viver de acordo com isso. Descobrirás como as mínimas despesas se amealham em grandes somas.

- Aquele que gasta um "groat" (sêmola) por dia, desperdiça mais de seis libras por ano, que é o preço do uso de cem libras.

Segundo Weber:

"O que aqui é pregado não é uma simples técnica de vida, mas sim uma ética popular, cuja infração não é tratada como uma tolice, mas como um esquecimento do dever. Essa é a essência do problema. O aqui preconizado não é mero bom senso comercial - o que não seria original mas sim um ethos. Essa é a qualidade que nos interessa".

Weber fala em algo mais do que um simples conjunto de ideias. Trata-se da formação de um conjunto de hábitos e costumes que configuram o caráter de uma dada comunidade. São costumes e traços comportamentais que distinguem uma determinada sociedade.

A formação de um ethos que se agrega a um clima de mobilização provocado pelo fator intangível do sentimento de entusiasmo ou depressão, gera a força motriz que leva a ações que modificam o status quo. No capítulo em que alinhamos a economia mundial e a nacional, percebemos como isso alterou as condições de organização e gestão dos clubes brasileiros.

O espírito do capitalismo expresso pelas sentenças de Franklin, destacadas por Weber, mostram um exemplo expressivo do que afirmamos acima. Somado à volúpia da sociedade americana na busca pelo enriquecimento pessoal, ele construiu um modo de vida econômico de um país.

No futebol, acima de tudo no Brasil, isso acontece, mas segue ignorado ou relativizado, chegando a ser completamente desconsiderado. E mesmo em se tratando do maior fator a criar um vazio cognitivo no entendimento do processo que norteia a gestão dos clubes, levou-os ao endividamento, à inviabilidade financeira, à submissão aos órgãos de administração do futebol e aos financiadores desse 
esporte. Como tratar da independência econômica dos clubes sem considerar isso?

O espírito do tempo atuou no futebol sem ser devidamente escrutinado, e forjou resultados positivos e negativos que procuramos trazer à discussão, acrescido do estudo das respectivas consequências.

A ação dos dirigentes não se configura plasmada apenas pelo caráter de cada um, como já mencionado, agregando-se ao aspecto pessoal, às possíveis idiossincrasias, um componente significativo de atitude, que copia a coletividade à qual pertence, provavelmente com peso maior, e que se inspira no espírito do tempo vigente.

Por isso, ao se analisar os modelos que podem levar os clubes à matriz econômica sustentável e de independência, objetivo da pesquisa, é indispensável entender o que se passa nos clubes sob esse aspecto, tanto no passado, que os remeteu à condição indesejada, como no presente, que os obriga a atualizações inexoráveis diante das demandas da atual economia do futebol. Os fatores intangíveis não podem ser negligenciados nem tratados com imperícia.

No livro seminal para entedermos o papel do esporte, e particularmente o do futebol, na vida social e nas relações humanas, "Deporte Y Ocio Em El Proceso De La Civilizacion", Norbert Elias e Eric Dunning destacam na Introdução de Elias:

\footnotetext{
"A pesquisa sociológica no campo dos esportes tem a tarefa de trazer à luz aspectos do esporte antes desconhecidos ou conhecidos apenas de maneira vaga. Em tais casos, o objetivo é fortalecer o conhecimento. Estávamos muito conscientes de que o conhecimento sobre o esporte também era conhecimento da sociedade." (ELIAS, DUNNING, 1986, p.31).
}

Também Elias e Dunning enleam a relação da sociedade com a emoção que é fator essencial no futebol:

\footnotetext{
"Nas sociedades industriais avançadas, as atividades recreativas são um reduto no qual, com a aprovação social, um nível moderado de emoção pode ser expresso em público.Não podemos compreender a natureza específica e as funções específicas do lazer nessas sociedades, se não percebermos que, em geral, no nível de controle das emoções tanto na vida pública quanto na vida privada, aumentou em relação às sociedades menos diferenciadas." (ELIAS, DUNNING, 1986, p.85).
} 
Em pleno 2020, a maior parte dos dirigentes de clubes, mesmo diante de modelos diversos, específicos a cada agremiação, administram dentro de um impulso muito conhecido no mercado financeiro: o comportamento de manada. Uns seguem os outros sem saber bem aonde estão indo, mas por enxergarem que os pares se movimentam em determinada direção.

Cuidando de incorporar essa dimensão pouco utilizada como referência para o sucesso dos modelos de gestão, destacam-se alguns fatores decisivos:

\subsubsection{A vaidade no manejar da matriz econômica}

Desde o século XVII, Blaise Pascal afirmou que a origem dos problemas estava naquilo que denominou de "o reino nefasto do amor-próprio". No futebol, ele é exponencial. Alguns presidentes de clubes são mais conhecidos na sociedade do que ministros de Estado e até presidentes da República. No governo de Fernando Henrique Cardoso (1995-2003) realizou-se uma pesquisa que mostrou que o ministro mais conhecido então era Adib Jatene, que já se notabilizara anteriormente como médico de expressão, com $6 \%$ de conhecimento público. Depois dele surgia o nome de Pedro Malan, Ministro da Fazenda, a Pasta mais relevante e diariamente na mídia: Malan tinha $3 \%$. Presidentes de clubes como Flamengo, Corinthians, Palmeiras, São Paulo, têm patamar entre $20 \%$ e $30 \%$.

A maioria chega ao cargo como ilustre desconhecido e passa a ter uma visibilidade imensa associada à solicitação permanente da mídia. Isso ocorreu com Paulo de Almeida Nobre, investidor do mercado financeiro que possuía fortuna significativa ao chegar à direção do Palmeiras, ocasião em que era desconhecido mesmo nos meios financeiros. Em pouco tempo passou a ter um grau de conhecimento destacado em todo o Brasil, e isso ajudou a reforçar características pessoais que foram distintivas nas decisões que tomou mais adiante no clube, com grande impacto no desempenho do mandato e consequências marcantes para o clube. Os patrocinadores atuais do Palmeiras, donos da empresa de financiamento Crefisa e da Faculdade das Américas-FAM, que possuíam patrimônio bilionário, eram figuras quase anônimas na sociedade brasileira, até mesmo nos círculos da 
sociedade que congregam pessoas mais ricas, tinham pouco destaque social, porém obtiveram um ganho sideral de visibilidade com alguns meses no Palmeiras.

O presidente Andrés Sanchez, empresário médio, percorreu a mesma trajetória de promoção de imagem. Embora isso seja incontroverso e aceito por todos, quando se estudam os modelos de gestão onde eles estão envolvidos e tomando decisões cruciais, tal fator não é levado em conta. Normalmente, o amorpróprio aflorado contribui para resultados negativos e que se desviam das diretrizes e rotas traçadas pelos modelos de gestão e seus respectivos arcabouços institucionais. Portanto, devem entrar na avaliação da perenidade do modelo, no risco que causam à manutenção e na quebra de contratos. $O$ descumprimento de contratos, antes bastante comum na vida dos clubes, decresceu substancialmente, embora não tenha se extinguido, a partir da consolidação de administrações mais profissionais, que surgiram após a Lei Pelé, sua modificação parcial que ficou conhecida como Lei de Responsabilidade dos Clubes $^{114}$ ou Lei de Moralização e o Estatuto do Torcedor ${ }^{115}$, que trouxeram marcos regulatórios ao futebol, além das injunções naturais advindas da presença de investidores também profissionais.

A vaidade é constitutiva no ser humano. Em Eclesiastes 1 isso está consagrado: "Vaidade de vaidades, vaidade de vaidades!Tudo é vaidade", e o futebol com a sua impressionante capacidade para promover os protagonistas exacerba o apetite. Pois ela é fator de risco crucial no manejar da matriz. O "reino nefasto do amor-próprio", muitas vezes também vinculado a interesses conflitantes, pesa de forma considerável, e portanto não pode ser esquecido na análise da estabilidade da matriz econômica que emerge do modelo de gestão novo pesquisado. Os clubes carecem de nomas que funcionem como freios e contrapesos à condição humana, em especial a hubris, para que ela não transcenda o métron. $E$ isso pode ser acrescido no instrumento de avaliação e controle por intermédio da mensuração do risco. Tal ideia procura contribuir como fato inovador no futebol.

\footnotetext{
114 Lei $n^{\circ}$ 13.155, de 04 de agosto de 2015 - Lei de Responsabilidade Fiscal do Esporte LRFE, que estabelece princípios e práticas de responsabilidade fiscal e financeira e de gestão transparente e democrática para entidades desportivas profissionais de futebol, cria - Programa de Modernização da Gestão e de Responsabilidade Fiscal do Futebol Brasileiro e dispõe sobre a gestão temerária no âmbito das referidas entidades.

${ }^{115}$ Lei no 10.671 , de 15 de maio de 2003 - Dispõe sobre o Estatuto de Defesa do Torcedor.
} 


\subsubsection{As pressões endógenas}

Nada diferencia mais um clube de outro do que a contingência da pressão exercida por torcedores e conselheiros, alavancada pela mídia e vinculada ao momento em curso.

Um time que não ganha campeonato há tempos e que possui torcida significativa, não se compara a rival que conta com a tolerância dos respectivos agentes por ter conquistado títulos recentes. O mesmo modelo de gestão sofre risco de quebra ou de intrusão quando a ansiedade por títulos se apresenta. Ou seja, tanto o investidor, como quem realiza a análise do modelo para verificar se ele é eficiente e tem perspectiva de perenidade, precisam acrescentar tal fator na avaliação. Mais uma vez, por se tratar de fator intangível, menos reconhecido que a questão egoica, ele pode ser citado, contudo não entra na mensuração do processo.

O Corinthians, na longa espera por títulos que enfrentou entre 1954 e 1977, teve por parte dos seus dirigentes atitudes inimagináveis do ponto de vista de coerência e lógica gerenciais. Isso poderia ser atribuído ao passado, onde a gestão era um ato quase que puramente emocional e destituído de valores da teoria administrativa. Porém, o comportamento se repetiu mais adiante, quando da espera pelo primeiro título nacional, que ocorreu em 1990. E foi reiterado continuadamente, mesmo após conquistas significativas.

No Palmeiras, o sistema de co-gestão com a Parmalat,empresa italiana de produtos alimentícios, que aportou recursos significativos para os valores da época, embora a espera não tenha sido nada longa, houve por parte do gestor maior da empresa, o presidente no Brasil, Gianni Grisendi, que pagou por atletas preços superiores aos que o mercado pedia para ter a garantia de sucesso na compra e na formação de um elenco que chegasse à conquista do campeonato, para justificar o investimento. Ou seja, ganhar campeonato era mais importante do que uma gestão financeira equilibrada, e o sistema de patrocínio da Parmalat não se preocupou com continuidade e estabilidade da geração de receita. Era uma matriz econômica instável, transitória, na base da introdução de recursos que não se 
sabia se poderiam ser mantidos. O Palmeiras saiu da fila de títulos com a Parmalat, para em seguida regressar a ela.

O alto investimento realizado pelo Palmeiras, proporcionado pela matriz econômica que pesquisamos, a do Allianz Parque, durante o período de 2017 e 2018 - cerca de 180 milhões de reais, muito acima dos rivais, mesmo levando em conta os títulos alcançados recentemente em 2015 e 2016 (este último retirando o Palmeiras de uma "fila" de 23 anos sem conquistar o campeonato nacional), causa pressão brutal sobre a diretoria, suscitando várias atitudes que contrastam com o discurso das diretrizes profissionais antes enaltecidas. A pressão por títulos faz a direção dos clubes abandonar a racionalidade econômica, e o aumento da arrecadação provoca rigor maior da torcida na cobrança por resultados.

A comparação com o Corinthians, que investiu menos de um quarto do valor referido ao Palmeiras no período e obteve dois campeonatos paulistas e um brasileiro no biênio destacado, somada aos insucessos seguidos no confronto direto do Palmeiras com o rival neste mesmo lapso de tempo, exerceram pressão que coloca em risco, até hoje, alguns tantos princípios administrativos e diretrizes gerenciais anteriormente incorporadas ao modelo que o Allianz Parque possibilitou ao clube.

Trata-se de outro fator a ser considerado na avaliação do modelo de gestão. O caminho para isso, que não é simples por lidar com a complexidade humana, e pelo fato da solução não se ater a roteiro pré-estabelecido de medidas administrativas, remete os controles do clube a evitar os fatores citados acima e adiante, e o entendimento de que há uma convivência, um equilíbrio instável, mas que deve ser buscado permanentemente entre a dicotomia títulos $x$ geração de riqueza perene.

\subsubsection{Subordinação, Insubordinação ao Arcabouço Vigente}

Os clubes considerados grandes ${ }^{116}$ faturam valores anuais que atingem centenas de milhões de reais, em geral mais de uma centena de milhão de dólares

\footnotetext{
116 Sociedade Esportiva Palmeiras; São Paulo Futebol Clube; Sport Club Corinthians
} Paulista; Santos Futebol Clube; Clube de Regatas do Flamengo; Botafogo de Futebol e 
que, na escala nacional de empresas, significa "empresa de grande porte", porém eles não possuem uma estrutura administrativa semelhante às das grandes empresas.

Os conselhos deliberativos e fiscais ou outros órgãos de controle não têm estrutura de funcionamento nem atribuições de fiscalização idênticas às empresariais, e esses vazios institucionais permitem manobras por parte das direções executivas que podem ameaçar o modelo de gestão, o que significa instabilizar a matriz econômica sustentável. Os vazios e as manobras, muitas vezes com o consentimento dos órgãos de controle e dos conselheiros, por conta de objetivos políticos internos ou de conveniências conjunturais erodem o modelo de forma não perceptível como uma doença assintomática que enfraquece o paciente. Como tudo isso é tratado na sociedade como mero embate político interno pelo poder, sem que se aprofunde suas implicações no processo de gestão, acaba por se transformar num fator de risco bastante perigoso. Como as direções se subordinam ou não às normas jurídicas e gerenciais é fator imprescindível a ser perscrutado na crítica ao modelo.Há uma questão crucial em tela, organizações que praticam transações comerciais de vulto, não podem ser consideradas entidades sem fins lucrativos, fato que a legislação brasileira acaba por permitir e que está sendo, em parte, encaminhada no Congresso com dois projetos, um já aprovado na Câmara, patrocinado pelo deputado Rodrigo Maia, que tem o vício de conceder perdão em multas e emolumentos e apresentado pelo dep. Pedro PauloRJ; e no Senado, ainda em curso que cuida da SAF, melhor estruturado.A autoria do projeto na sua origem foi trabalho dos advogados Rodrigo R. Monteiro de Castro e José Francisco C. Manssur e apresentado pelo senador Rodrigo Pacheco, com o objetivo de criar base concreta para formar o ambiente necessário para o funcionamento dos clubes na realidade da Economia de Mercado, sem perder a demanda de origem ancorada na paixão.Só um novo arcabouço jurídico, onde a SAF é parte, poderá amenizar os efeitos acima citados. A SAF deve ter regime jurídico próprio, que incorpore e regule as caracter[isiticas e as circunstâncias

Regatas, Club de Regatas Vasco da Gama; Fluminense Footbal Club; Cruzeiro Esporte Clube; Clube Atlético Mineiro; Grêmio Foot-Ball Porto Alegrense; Sport Clube Internacional. 
especiais e extraordinárias da atividade a que se dedicará, conforme explicitam seus autores.

\subsubsection{Ilusão do Profissionalismo}

O decantado profissionalismo apregoado pelos dirigentes que defendem a agenda mais modernizadora do futebol tem tiro curto e pouca profundidade. Quando perscrutado, com raras exceções, se atém ao "pagamento a profissionais em cargos de direção e no comando gerencial subordinado ao departamento de futebol do clube". Tomam tal como suficiente. As relações desses profissionais com os diretores estatutários do clube, não-remunerados, que em geral aparecem no recinto de trabalho ao final do dia, por horas, e têm poder de decisão que pode contrariar os profissionais, não são levadas em conta, anulando o que seria o conhecimento técnico aplicado sem o viés "político". Nem essas relações, nem a interação desses profissionais com empresários conhecidos, que possuem interesses próprios, em conflito de interesse com o clube, e também a relação de compadrio entre esses profissionais, que uma vez egressos, vão compartilhar funções em outras agremiações.Quando o sistema de gestão é tênue, não havendo normas e procedimentos impessoais e baseados na técnica gerencial esses itens expostos acima, minam substancialmente 0 desenrolar $e \quad 0$ desempenho dos modelo de gestão.Outros fatores tangenciam o processo, mas não com o peso dos acima mencionados, ocorrendo, talvez, a importância conjuntural na vida de determinado clube, merecendo então tratamento específico, caso a caso.

Desde o aparecimento dos primeiros clubes, final do século XIX e início do século $\mathrm{XX}$, temos o impacto das questões intangíveis, todavia, como enunciamos, elas são desconsideradas mesmo nos tempos atuais, quando a profissionalização do esporte ganhou outra dimensão e relevância. Acreditamos que a desconsideração aludida constitui-se em objeto que esse trabalho procura trazer como inovação no campo analítico.

Apesar dos números e evidências comportamentais de clubes do exterior, acima de tudo na Europa, e estabelecida a dimensão da Nova 
Economia, ainda assim, as agremiações brasileiras demoraram para enxergá-la como fator relevante para a constituição de suas respectivas matrizes de sustentação financeira. Por receio de lidar com o desconhecido ou por medo que isso atrapalhasse a condução pessoal que faziam, optaram por ignorá-la. Também foi assim na SEP. Ocorre que a dinâmica econômica não se detém diante do alheamento à sua realidade, de alguma forma ela vai pressionando ou encurralando as atividades expostas no mercado, funcionado como um fluxo de água gigantesco à montante, que, em certo instante, transpassa a barragem. O mercado segue a direção de ontem há riqueza gerada, sobretudo se não explorada. Negá-lo, só aguça a dificuldade no tratamento dos problemas. A Economia do Futebol adentrou ao Palmeiras pela construção do Allianz Parque.

\subsection{Parâmetros de Medição de Eficiência e Eficácia do Modelo}

A primeira questão que se impõe quando se deseja criar parâmetros de mensuração de desempenho dos modelos de gestão de clubes é a dimensão do faturamento. Uma empresa é considerada de grande porte segundo o padrão BNDES-OCDE-IBGE, quando possui mais de 249 funcionários, no Brasil, também se utiliza o faturamento acima de 300 milhões para classificar como "grande porte", e a Sociedade Esportiva Palmeiras cumpre as duas exigências tendo faturado 524 milhões em 2017, e 688 milhões em 2018. Portanto, estamos diante de uma empresa dessa dimensão, que requer gestão profissional e de alto nível, mas, além dessa exigência, sabemos que também precisa de títulos, todos precisam de resultados em campo, nenhum pode prescindir do desempenho esportivo, tornando-os empresas peculiares.

$\mathrm{Na}$ realidade, nenhuma torcida, mesmo o contingente que mais se comporta como cliente e demanda posturas voltadas à indústria do entretenimento, se contenta só com o espetáculo, com o conforto, segurança, acesso e boa alimentação. A ideia de ter o futebol jogado apenas por jogar, mencionada por GALEANO (Apud LEONCINI, 2001), não se sustenta mais. Se não houver títulos 
ou desempenho aceitáveis, os torcedores restringem sua participação, gerando queda na receita. Além disso, provocam um clima bastante hostil, pressionam, suscitando ações por parte da direção, muitas vezes na direção oposta à preconizada pelas boas práticas administrativas, como contratações dispendiosas, acima da capacidade financeira do clube. Sem títulos ou desempenho, as fontes de receita minguam, aumentando a possibilidade de desatinos orçamentários, e o risco se eleva perigosamente. Logo, como temos reiterado pela importância na solução pela busca da matriz econômica, base desse trabalho, e que emergiu no Palmeiras com o Allianz Parque, não se pode ignorar ou menosprezar esse antagonismo formal, onde incidem sobre a direção do clube fatores modernizantes em termos de administração de empresas, noções e normas de gestão, que induzem a tomar decisões mais racionais; e fatores vinculados à necessidade de sucesso no campo, que se somam à passionalidade mais arcaica e irracional.

A questão que se coloca é: o que estamos medindo?

Antes de nos aprofundarmos na indagação colocada, cabe discutir o porquê da inclusão do capítulo. Se estamos pesquisando um modelo que resulte numa matriz econômica a permitir gestão estável, sistêmica, que produza autonomia política e independência financeira, cabe sabermos como mensurar se o modelo está funcionando e de que necessita para se consolidar. O modelo não pode ser volátil na sua efetividade, sob pena de não sustentar as premissas de estabilidade financeira.

Uma das grandes incompletudes dos estudos realizados é exatamente essa: não há sistema de avaliação que forneça informações para aprimorá-lo, corrigi-lo ou modificá-lo. Acrescenta-se a esse hiato, o desprezo pelos fatores intangíveis vinculados à atitude do dirigente e a governança do clube, como já vimos anteriormente. Assim, os estudos efetuados restam perigosamente inconclusos no sentido de propiciarem caminho aplicável e estável. Não basta, contudo apontar os defeitos nem nos contentarmos com o relato das inconformidades dos modelos de gestão, é preciso pesquisar um sistema que possa servir de modelo real, passível de controle e avaliação permanentes. 
O segundo ponto a se observar nessa busca por um modelo que não seja meramente acadêmico, e não se atenha a considerações limitadas, é evitar a "matematização" dos sistemas de avaliação, equívoco comum a quem opta pelo apego exacerbado à econometria. Keynes já dizia, que não existem bases matemáticas suficientes para se metrificar as decisões humanas, e que a nossa inteligência, apesar de calcular sempre a favor da melhor alternativa, muitas vezes se retrai diante do capricho, do sentimento ou do azar.

O que buscamos com esse capítulo é incluir, tanto quanto possível, o capricho e o sentimento, via a inserção dos fatores intangíveis, e procurar levar em consideração de forma adicional aqueles pontos intocáveis que não cabem na equação matemática de mensuração.

Considerando todos os fatores acima referidos, a melhor ferramenta encontrada para efetuar tal medição é o Balanced Scorecard ${ }^{117}$, conhecido pela sigla BSC, lançado por dois professores de Harvard, em artigo publicado em 1992, "Balanced Scorecard: Medidas que Impulsionam o Desenvolvimento", que teve importante repercussão no meio acadêmico e empresarial, como uma metodologia nova para mensurar o desempenho das organizações, sem estar atrelado tão somente a métricas unicamente com foco em resultados financeiros. Trata-se de modelo de gestão estratégica que auxilia a medição do progresso das instituições as quais ele é aplicado, rumo às suas metas de longo prazo, a partir da tradução da estratégia em objetivos, metas, indicadores e iniciativas operacionais.

Portanto, o conceito de BSC apresenta os seguintes termos-chave:
a) Gestão Estratégica;
b) Objetivos;
c) Metas;
d) Estratégia;
e) Iniciativas Operacionais.

117 Balanced Scorecard, em português seria traduzido como "Indicadores Balanceados de Desempenho", é uma metodologia de medição e gestão de desempenho desenvolvida em 1992 pelos professores da Harvard Business School Robert Kaplan e David Norton. 
$\mathrm{O}$ artigo se transformou em um dos livros mais vendidos na área de gestão estratégica e planejamento, chamado "A Estratégia em Ação - Balanced Scorecard', de David P. Norton e Robert S. Kaplan ${ }^{118}$.

Balanced Scorecard é uma ferramenta de planejamento estratégico onde a empresa determina com clareza e objetividade as metas e estratégias visando medir o desempenho por intermédio de indicadores quantificáveis e mensuráveis.

A mensuração do progresso ocorre por intermédio de 4 perspectivas:

a) Perspectiva financeira:

- Perspectiva Financeira: Para satisfazer nossos acionistas (donos ou direção do clube). Quais objetivos financeiros devemos seguir?

b) Perspectiva de mercado:

- Perspectiva do Mercado (Clientes): Para atingir nossos objetivos financeiros, que necessidades de nossos clientes devemos atender?

c) Perspectiva de processamento interno:

-Perspectiva de Processos Internos: Para satisfazer nossos clientes e acionistas, em quais processos internos devemos ser excelentes?

d) Perspectiva de aprendizado:

- Perspectiva de Aprendizado e Crescimento: Para atingir nossas metas, como nossa organização deve aprender e inovar?

\subsubsection{Balanced Scorecard, Conceito}

Diz o conceito da BSC: para tornar a empresa mais valiosa e lucrativa é preciso satisfazer o mercado e clientes. Para isso, é imperativo melhorar nossos processos internos, o que só será possível se aprendermos com a experiência e

118 KAPLAN, R. S. e NORTON, D.P. A Estratégia em Ação: Balanced Scorecard. Rio de Janeiro: Campus, 1997. 
praticarmos a inovação. Depois de definir cada uma das perspectivas, ao responder essas perguntas, é preciso transformar a estratégia em ação.

Dessa forma, elementos importantes que fazem parte do conceito de Balanced Scorecard (BSC) deverão ser determinados para cada perspectiva individualmente.Definidos os objetivos, indicadores, metas e projetos estratégicos se constrói o Mapa Estratégico do Balanced Scorecard.

\subsection{Mapa Estratégico}

O resultado final de tudo isso deve ser uma espécie de quadro resumo do conceito de Balanced Scorecard que deverá ser aplicado.

O mapa é dividido em 4 faixas, cada uma referente a uma das 4 perspectivas estratégicas.

As faixas são ordenadas de cima para baixo, nesta ordem:

1. Perspectiva Financeira;

2. Perspectiva do Mercado;

3. Perspectiva de Processos Internos;

4. Perspectiva de Aprendizado.

Em seguida, coloca-se em cada faixa, caixas com as iniciativas estratégicas que serão tomadas em cada uma delas, para que as perspectivas consigam atingir seus objetivos. Em alguns casos, é comum colocar setas de uma caixa para outras, em faixas diferentes ou nas mesmas, indicando como a iniciativa favorecerá outras, em diferentes perspectivas. 
Vale lembrar também que algumas empresas usam perspectivas próprias, diferentes dessas 4 mais usadas. Apresentamos como referência o Mapa Estratégico do Banco VW'119.

Tabela 46 - Mapa Estratégico do Banco Volkswagen

\begin{tabular}{|c|c|c|c|c|c|c|c|}
\hline Rentabilidade & \multicolumn{7}{|c|}{$\begin{array}{c}\text { Gerar a rentabilidade esperada pelo acionista } \\
\text { - Otimizar margens }\end{array}$} \\
\hline Volume & \multicolumn{3}{|c|}{$\begin{array}{l}\text { Consolidar a liderança em } \\
\text { financiamentos } \\
\text { - Novos } \\
\text { - Seminovos }\end{array}$} & \multicolumn{4}{|c|}{$\begin{array}{l}\text { Ampliar participação dos negócios de consórcio, } \\
\text { mobilidade e seguros }\end{array}$} \\
\hline Clientes & $\begin{array}{c}\text { Entender as } \\
\text { necessidades dos } \\
\text { clientes para } \\
\text { oferecer os } \\
\text { melhores produtos } \\
\text { e serviços }\end{array}$ & \multicolumn{2}{|c|}{$\begin{array}{l}\text { Aumentar a } \\
\text { lealdade e } \\
\text { retenção dos } \\
\text { clientes }\end{array}$} & \multicolumn{3}{|c|}{$\begin{array}{l}\text { Aprimorar os canais de } \\
\text { comercialização e } \\
\text { relacionamento com o cliente } \\
\text { - Digital } \\
\text { - Presencial }\end{array}$} & $\begin{array}{c}\text { Atuar com o } \\
\text { parceiro } \\
\text { estratégico das } \\
\text { marcas e } \\
\text { concessionárias do } \\
\text { Grupo Volkswagen }\end{array}$ \\
\hline $\begin{array}{l}\text { Excelência } \\
\text { Operacional }\end{array}$ & $\begin{array}{c}\text { Identificar e } \\
\text { gerenciar riscos } \\
\text { ativamente } \\
\text { - Financeiros e não } \\
\text { financeiros } \\
\text { - Compliance }\end{array}$ & \multicolumn{2}{|c|}{$\begin{array}{c}\text { Tornar os } \\
\text { processos mais } \\
\text { ágeis e eficientes, } \\
\text { melhorando a } \\
\text { experiência do } \\
\text { cliente }\end{array}$} & $\begin{array}{l}\text { Elevar o grau } \\
\text { de maturidade } \\
\text { na gestão de } \\
\text { projetos }\end{array}$ & \multicolumn{2}{|c|}{$\begin{array}{c}\text { Assegurar a } \\
\text { estabilidade } \\
\text { dos sistemas e } \\
\text { introduzir } \\
\text { novas soluções } \\
\text { para suportar } \\
\text { os negócios }\end{array}$} & $\begin{array}{l}\text { Otimizar a gestão } \\
\text { de custos e } \\
\text { investimentos } \\
\text { - Diretos e } \\
\text { indiretos } \\
\text { - Captação }\end{array}$ \\
\hline Pessoas & \multicolumn{2}{|c|}{$\begin{array}{l}\text { Atuar como um time de alta } \\
\text { performance cultivando um } \\
\text { excelente ambiente de } \\
\text { trabalho }\end{array}$} & $\begin{array}{r}\mathrm{Se} \\
\text { organiza }\end{array}$ & $\begin{array}{l}\text { conhecida com } \\
\text { ção com forte c } \\
\text { com o cliente } \\
\text { - Interno } \\
\text { - Externo }\end{array}$ & o uma & & $\begin{array}{l}\text { pliar a capacidade } \\
\text { nalítica aplicada à } \\
\text { mada de decisão }\end{array}$ \\
\hline
\end{tabular}

Fonte: (Banco VW) acesso em 10/03/2018

119 Banco Volkswagen - A Volkswagen Financial Services é responsável pelas operações financeiras do Grupo Volkswagen em todo o mundo. No Brasil, o conglomerado é constituído pelo Banco Volkswagen, Consórcio Nacional Volkswagen e Volkswagen Corretora de Seguros. 
O Banco VW usa perspectivas estratégicas próprias, específicas de seu negócio. O BSC deve ser adequado à realidade da instituição a qual está sendo aplicado, no nosso caso, um clube de futebol. Cabe adaptar o Mapa Estratégico da Balanced Scorecard aos clubes de futebol no Brasil, inserindo as questões tangíveis e intangíveis relevantes para a avaliação do desempenho do modelo de gestão aplicado.

É o passo que daremos a seguir.

Tabela 47 - Mapa Estratégico do Futebol

\begin{tabular}{|c|c|c|c|c|}
\hline Receita & \multicolumn{4}{|c|}{$\begin{array}{l}\text { Gerar a receita esperada pela direção e Conselhos . } \\
\text { Otimizar margens. }\end{array}$} \\
\hline Posicionamento & \multirow{2}{*}{$\begin{array}{l}\text { Consolidar } \\
\text { liderança na } \\
\text { conquista de } \\
\text { títulos } \\
\text { nacionais e } \\
\text { regionais } \\
\text { Aumentar e } \\
\text { manter a } \\
\text { regularidade e } \\
\text { fidelidade no } \\
\text { programa } \\
\text { Sócio } \\
\text { Torcedor } \\
\text { (Avanti) }\end{array}$} & \multicolumn{3}{|c|}{$\begin{array}{l}\text { Ampliar participação nos torneios internacionais } \\
\text { mais importantes } \\
\text { Libertadores da América } \\
\text { Mundial de Clubes }\end{array}$} \\
\hline Clientes & & $\begin{array}{l}\text { Tornar a } \\
\text { frequência nos } \\
\text { jogos um } \\
\text { espetáculo } \\
\text { inesquecível. } \\
\text { Criar desejo e } \\
\text { prazer além } \\
\text { do conforto. }\end{array}$ & $\begin{array}{l}\text { Aprimorar } \\
\text { canais de } \\
\text { comercialização } \\
\text { de outros } \\
\text { produtos e } \\
\text { serviços }\end{array}$ & $\begin{array}{l}\text { Criar parcerias } \\
\text { entre } \\
\text { patrocinadores } \\
\text { e torcedores }\end{array}$ \\
\hline $\begin{array}{l}\text { Eficiência } \\
\text { Operacional }\end{array}$ & $\begin{array}{l}\text { Identificar } \\
\text { riscos no } \\
\text { desempenho } \\
\text { financeiro }\end{array}$ & $\begin{array}{l}\text { Assegurar a } \\
\text { estabilidade } \\
\text { orçamentária } \\
\text { e evitar gastos } \\
\text { além do } \\
\text { planejado }\end{array}$ & $\begin{array}{l}\text { Definir normas } \\
\text { de gestão } \\
\text { tornando os } \\
\text { processos } \\
\text { impessoais é } \\
\text { imune às } \\
\text { pressões não } \\
\text { profissionais } \\
\end{array}$ & $\begin{array}{l}\text { Otimizar } \\
\text { gestão de } \\
\text { custos }\end{array}$ \\
\hline Pessoas & $\begin{array}{l}\text { Atuar como } \\
\text { equipe de alta } \\
\text { performance, } \\
\text { harmonizando } \\
\text { accão da } \\
\text { direção, } \\
\text { conselheiros, } \\
\text { equipe } \\
\text { profissional e } \\
\text { torcedores }\end{array}$ & $\begin{array}{l}\text { Criar canal } \\
\text { oficial, } \\
\text { sistêmico e } \\
\text { ativo para } \\
\text { participação } \\
\text { de torcedores } \\
\text { conforme } \\
\text { Estatuto do } \\
\text { Torcedor. Lei } \\
1067 / 2013\end{array}$ & \multicolumn{2}{|c|}{$\begin{array}{l}\text { Ampliar a capacidade de juntar } \\
\text { desempenho financeiro e } \\
\text { conquista de títulos }\end{array}$} \\
\hline
\end{tabular}

Fonte: O próprio Autor - 17/05/2019 
A partir do Mapa Estratégico são definidas as metas e os respectivos indicadores. A fim de atingir as metas assentam-se planos de ação que são acompanhados, controlados e corrigidos para que as metas sejam satisfeitas. $O$ Mapa apresentado pode ser utilizado especificamente para o Palmeiras e, desde que adaptado, aplica-se a outros clubes como exemplo.

O BSC permite planejamento, controle e gestão muito mais condizente com a realidade dos clubes de futebol porque estende sua ação para além das métricas com foco em resultados financeiros como já mencionamos anteriormente.Isso nos parece a melhor forma de concertar as peculiaridades dos clubes de futebol. A ponderação a ser dada a cada meta e a harmonia entre elas será um fator distintivo que cada clube deverá contemplar.

O conjunto de dados apresentados explicita a renda auferida, a nova riqueza gerada pelo Allianz Parque, colocando a Sociedade Esportiva Palmeiras em condições de independência econômica, que se estabeleceu com a relativização das receitas por conta da cessão de direitos de transmissão - dinheiro da TV e Internet - e da prescindibilidade da obrigação de vender atletas para equilibrar o orçamento. Porém, a forma como é gerada tal riqueza nos permite descortinar a relevância de outros fatores que vão além da matriz econômica. Missão dos clubes, diferenciada de empresa comum que visa apenas ao lucro, o relacionamento com o torcedor, ativo principal na geração de receita, incluindo o torcedor com menos renda, modelos de governança, enfim, um conjunto que, conforme o manejo, pode alcançar o sucesso desejado. O fator humano entra em campo, acarretando a necessidade de estabelecimento de parâmetros para acompanhamento do modelo de gestão e para a mensuração da eficiência e eficácia do sistema. Cabe caminhar além da matriz econômica, contemplando todos os quesitos aludidos no presente capítulo.

Outro ponto fundamental é o entendimento dos modelos de construção e constituição da administração do estádio. Não basta ter um estádio e se almejar fazer dele um ativo para geração de riqueza. $O$ modelo faz a diferença, como veremos no capítulo seguinte. 


\section{CAPÍTULO VI - COMPARAÇÃO COM OUTROS MODELOS}

Com a definição, em 2007, do Brasil como país anfitrião da Copa do Mundo de 2014, como já se reiterou, impôs-se a necessidade de estádios com "padrãoFIFA" que pudessem sediar os jogos oficiais. Entre os estádios selecionados constituíram-se modelos diferentes de incorporação, que levaram a resultados bem diversos.

Desde o início das tratativas junto à CBF para escolha do estádio que sediaria a abertura e os jogos da Copa do Mundo FIFA 2014 em São Paulo, a construção da Arena Corinthians foi objeto de polêmicas. Inicialmente estava previsto que o estádio do Morumbi, de propriedade do São Paulo Futebol Clube, sediaria a abertura do evento, mas segundo noticiado à época, desentendimentos em relação aos custos e ao financiamento das obras de reforma necessárias à adaptação ao "padrão-FIFA", dentre outros fatores, acarretarem o descarte dessa opção em junho de 2010.

$\mathrm{Na}$ ocasião chegou-se a estudar outras possibilidades, como a construção de um novo estádio pelo Governo do Estado na região de Pirituba, zona oeste da capital, ou a reforma do estádio municipal do Pacaembu. Por fim, a CBF acabou por sugerir à Prefeitura e ao Governo do Estado que a abertura da Copa fosse realizada no estádio que o Corinthians pretendia erguer em seu centro de treinamento em Itaquera, na zona leste de São Paulo.

\subsection{Arena Corinthians}

Para construção da Arena Corinthians optou-se pela alternativa de estádio privado com dinheiro público dos $\mathrm{CIDs}^{120}$ da Prefeitura de São Paulo, repasse da

${ }^{120}$ CIDs - Certificados de Incentivo ao Desenvolvimento, são títulos emitidos pelo poder público na modalidade "incentivo fiscal". Especificamente no caso da Arena Corinthians, os "papeis" foram emitidos pela Prefeitura de São Paulo como contrapartida aos benefícios à economia da Zona Leste pelo estádio e a abertura da Copa do Mundo de 2014. A lei de incentivo à abertura da Copa, em Itaquera, foi uma adaptação da Lei 13.833, de 2004, que disciplina o incentivo fiscal à Zona Leste. Ela foi aperfeiçoada pelas Leis Municipais 14.654, de 20/12/2007, e 14.888, de 19/01/2009, que definem a área de abrangência dos incentivos. 
Caixa Econômica Federal e empréstimo do BNDES com juros TJLP ${ }^{121}$, que são subsidiados.

Tomada a decisão pela construção de um estádio no terreno do Corinthians para sediar a abertura oficial da Copa de 2014, o então Prefeito Gilberto Kassab sancionou a Lei Municipal no 15.413/2011, concedendo incentivos fiscais para a construção da Arena Corinthians e definindo o modelo de concessão a ser utilizado. Referida lei teve sua legalidade questionada pelo Ministério Público de São Paulo, especialmente pelos incentivos concedidos e pelo fato de não ter havido licitação para escolha da Odebrecht como empresa responsável pela construção. Segundo entendimento da Prefeitura, a licitação seria desnecessária por se tratar de obra privada. O parquet paulista, por sua vez, questionou a medida em razão do dinheiro público envolvido na construção, o que em tese exigiria a realização de certame licitatório. Contudo, o Tribunal de Justiça de São Paulo, por maioria, em julgamento realizado em abril de 2018, considerou constitucional a Lei Municipal 15.413/2011, não reconhecendo, na hipótese, a prática de atos de improbidade administrativa por parte dos agentes públicos e privados que definiram o modelo utilizado.

Outro ponto polêmico relacionado à construção da Arena Corinthians diz respeito ao custo total da obra, inicialmente orçada em $R \$ 850$ milhões. Além dos atrasos na conclusão, o valor da construção do estádio foi $\mathrm{R} \$ 985$ milhões, porém acrescendo-se juros e overlay (estruturas temporárias utilizadas na Copa do Mundo), o custo final supera $\mathrm{R} \$ 1,64$ bilhão ${ }^{122}$. Após a inauguração o Corinthians afundou-se em dívidas, e em 2019 a Odebrecht lhe apresentou uma cobrança no valor de $\mathrm{R} \$ 800$ milhões, para ao final obter uma renegociação junto ao clube (amplamente anunciada pela mídia), fechando um acordo para pagamento de $\mathrm{R} \$$ 160 milhões, mais a totalidade dos valores relativos aos CIDs emitidos pela Prefeitura de São Paulo ainda restantes quando da formalização do ajuste. Com relação à Caixa Econômica Federal, o Corinthians tomou $\mathrm{R} \$ 400$ milhões em

${ }^{121}$ TJLP - Taxa de Juros de Longo Prazo. 122

file://C:/Users/Intel/Desktop/ARQUIVOS\%20TESE/PESQUISA\%20ARENA\%20CORINTHI ANS/Arena\%20Corinthians_\%200\%20que\%20sabemos\%20sobre\%20a\%20renegocia\%C3 $\%$ A7\%C3\%A30\%20da\%20d\%C3\%ADvida\%20do\%20clube\%20com\%20a\%20Odebrecht\% 20_\%20corinthians\%20_\%20Globoesporte.html 
empréstimos, e mesmo pagando as parcelas do financiamento, em agosto de 2019 a dívida já estava em $R \$ 470$ milhões, em razão dos juros do contrato. Estima-se que a dívida do Corinthians, somando-se os valores devidos à Odebrecht e à Caixa Econômica Federal, seja equivalente, hoje, a $\mathrm{R} \$ 630$ milhões.

Figura 14 - Modelo de Financiamentoda Arena Corinthians FINANCIAMENTO

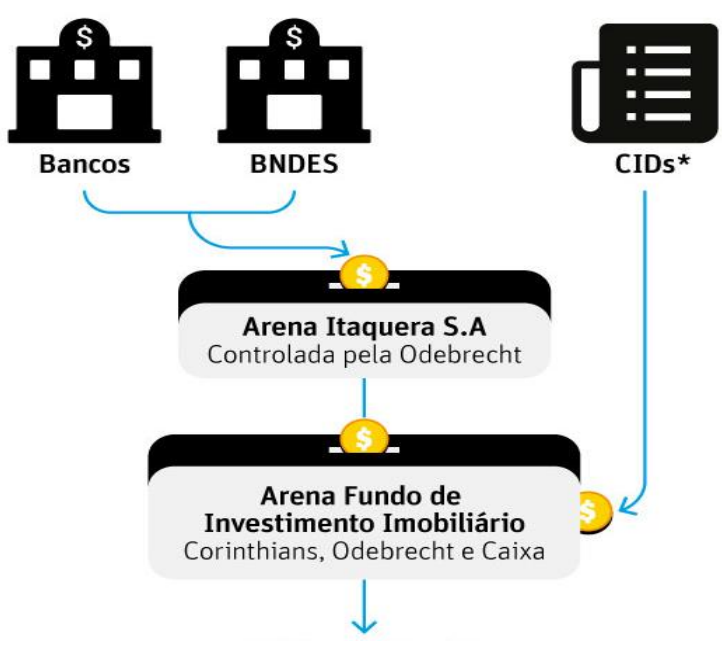




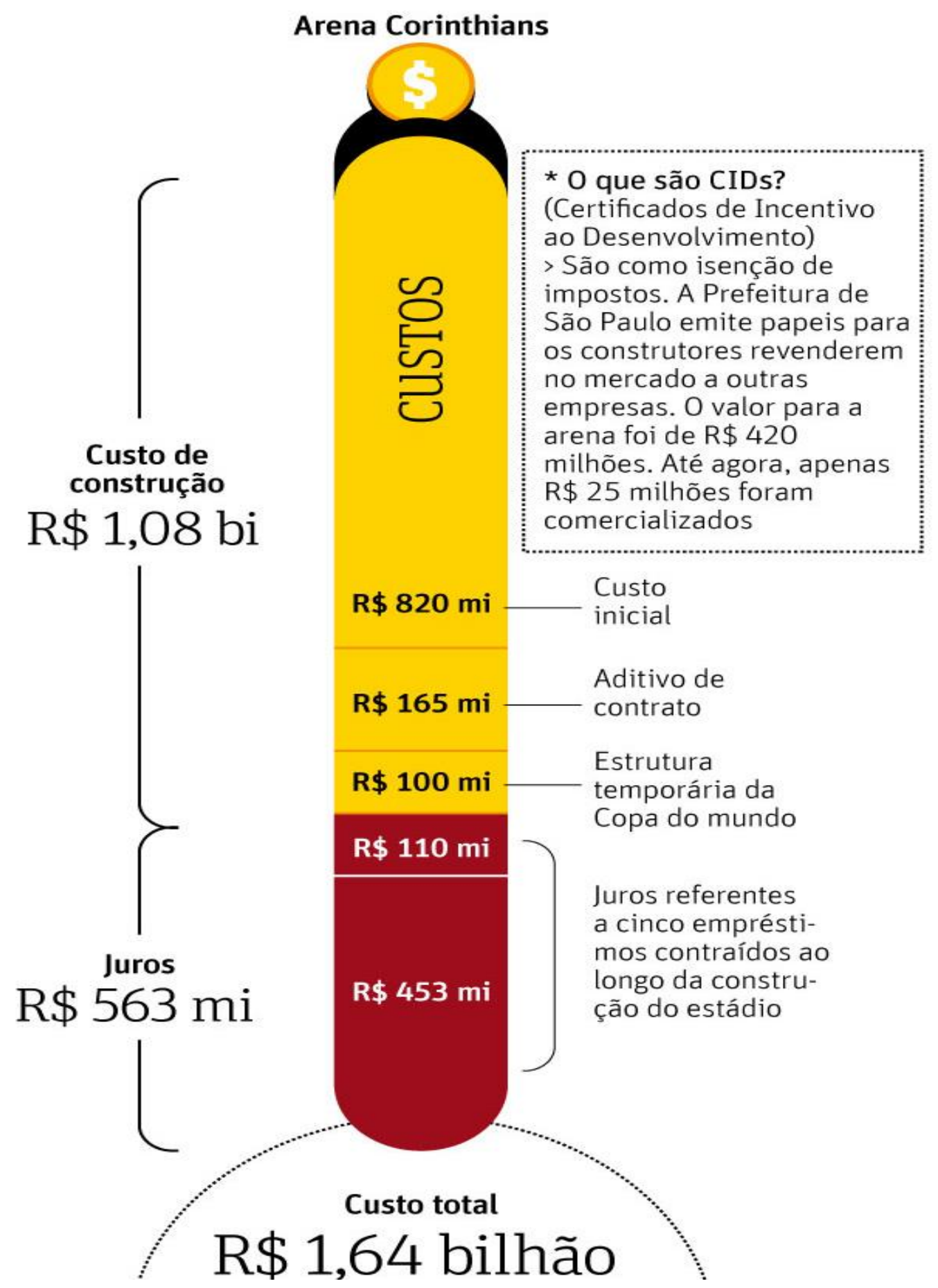

Fonte: (Folha de S.Paulo) - acesso em 15/04/2018

Além das inúmeras polêmicas citadas, em especial as relativas à concessão de incentivos fiscais, empréstimo de dinheiro público, não realização de licitação para escolha da empresa construtora e aos elevados custos da obra, outras situações relacionadas aos diversos percalços enfrentados para a inauguração da Arena Corinthians podem ser 
mencionadas: a morte de três operários durante a construção, o grande atraso na inauguração (a menos de um mês da abertura da Copa) e até polêmicas envolvendo a escolha do nome do estádio. Importante destacar, ademais, os impactos sofridos no entorno da Arena, tanto positivos (melhoria da infraestrutura geral da região, especialmente iluminação e policiamento), como negativos (a exemplo da forte alta nos preços dos imóveis e alugueis na região de Itaquera, a escassez de políticas públicas mitigadoras, dentre outros). Segundo estudo realizado sob orientação da Fundação Getúlio $\operatorname{Vargas}^{123}$ acerca do tema, destaca-se a importância do alinhamento das expectativas da sociedade civil e da formulação de políticas públicas colaborativas para o alcance dos efeitos pretendidos pelos interessados clubes, investidores, atletas, torcedores:

\begin{abstract}
"Ao final das três rodadas de entrevistas/diálogos previstas, foi possível notar: a ausência de canais de interlocução efetivos entre a população e o poder público; o descolamento entre as demandas dos atores locais e as políticas públicas formuladas pelo Estado; a percepção de benefícios exíguos gerados aos comerciantes; a existência de processos de gentrificação no entorno do estádio; e a melhora de alguns serviços públicos na região - como iluminação pública e policiamento. Entretanto, há desconfiança dos empresários locais quanto à manutenção da prestação desses serviços após a Copa do Mundo. Mas as obras do Complexo Viário Polo Itaquera foram um ponto positivo para a mobilidade da região, segundo os relatos. Respondendo às questões colocadas por este projeto de pesquisa, os impactos gerados pelo conjunto de ações promovidas até então pelo poder público no entorno da Arena Corinthians não são entendidos como desenvolvimento. A incapacidade - ou mesmo indisposição - de inserir os atores locais nos processos decisórios, somada aos resultados aquém do esperado, embasa esse posicionamento. Enquanto a Administração Pública se mantiver alheia às demandas e expectativas da sociedade civil, raras serão as experiências de pleno desenvolvimento - nas quais direitos são reconhecidos e garantidos, e as políticas públicas são formuladas de maneira colaborativa entre Estado e cidadãos."
\end{abstract}

Por todo exposto, em especial a crítica situação das finanças do clube, que como demonstrado acumula uma dívida de aproximadamente $\mathrm{R} \$ 630$ milhões,

123 "O IMPACTO ECONÔMICO DA CONSTRUÇÃO DO ESTÁDIO DO CORINTHIANS NO PROCESSO DE DESENVOLVIMENTO LOCAL DO BAIRRO DE ITAQUERA - SÃO PAULO", 2014, Vitor Knöbl Moneo Chaves - Orientador: Prof. Fernando Burgos Pimentel dos Santos 
pode-se pressupor que o modelo adotado para a construção da Arena não trouxe ao Sport Clube Corinthians Paulista uma matriz econômica sólida, apta a Ihe propiciar a necessária e almejada independência financeira, diferentemente do exemplo de sucesso alcançado pela Sociedade Esportiva Palmeiras através do modelo do Allianz Parque, fulcro do presente trabalho.

A Ttítulo de comparação entre os dois estádios - Allianz Parque e Arena Corinthians, alguns dados ${ }^{124}$ merecem destaque:

(a) Naming Rights

Arena Corinthians: o clube ainda não conseguiu fechar nenhum acordo, mas segue buscando.

Allianz Parque: a WTorre fechou um acordo com a seguradora Allianz que pagará 300 milhões de reais por 20 anos de exposição.

(b) Tamanho e capacidade

Arena Corinthians: o estádio tem 190 mil $\mathrm{m}^{2}$ de área construída e capacidade para receber 48 mil pessoas. Não são todos os lugares que têm cobertura.

Allianz Parque: a casa palmeirense tem $140 \mathrm{mil} \mathrm{m}^{2}$ de área construída e pode receber até 43,6 mil pessoas em cadeiras cobertas.

(c) Camarotes

Arena Corinthians: 89 unidades.

Allianz Parque: 160 unidades.

(d) Acesso

Arena Corinthians: o acesso ao estádio pode ser feito por duas estações de metrô (Arthur Alvim e Corinthians-Itaquera) ou pela estação Corinthians-Itaquera da

\footnotetext{
${ }^{124} \mathrm{https}: / /$ exame.abril.com.br/brasil/classico-compare-as-novas-casas-de-corinthians-epalmeiras/
} 
CPTM, que abriga também um terminal de ônibus. De todos os jeitos, o torcedor tem que caminhar cerca de 800 metros até as entradas do estádio.

Allianz Parque: a estação de metrô mais próxima ao estádio é Palmeiras Barra Funda, tem ônibus e uma estação da CPTM.

(e) Estacionamento:

Arena Corinthians: 2.549 vagas.

Allianz Parque: 2.000 vagas.

(f) Campo

Arena Corinthians: 105 metros de comprimento por 68 de largura - padrão Fifa. A distância entre o campo e as arquibancadas é de 9 metros.

Allianz Parque: 105 metros de comprimento por 68 metros de largura padrão Fifa. A distância entre o campo e as arquibancadas é de 14,6 metros.

\subsection{Maracanã}

O Maracanã, pertencente ao governo do Estado do Rio de Janeiro, enveredou pela opção estádio público com dinheiro público e concessão à iniciativa privada. $\mathrm{A}$ reforma desse estádio foi a obra mais cara da Copa do Mundo 2014, tendo custado $\mathrm{R} \$ 1,2$ bilhão, quase o dobro dos $\mathrm{R} \$ 700$ milhões previstos no projeto vencedor da licitação. Um dos fatores encarecedores da obra foi a substituição da cobertura das arquibancadas, que segundo o projeto inicial seriam preservadas. A nova estrutura é similar à do Soccer City de Joanesburgo, África do Sul, palco da final da Copa de 2010, mas custou cinco vezes mais ${ }^{125}$.

Grandes escândalos foram revelados envolvendo a reforma do Maracanã, como mau uso e desvio dos recursos públicos utilizados, conforme apontado em auditoria realizada pelo Tribunal da Contas da União e em investigações realizadas pela Polícia Federal e Ministério Público do Rio. Segundo consta das investigações

${ }^{125}$ https://g1.globo.com/rio-de-janeiro/noticia/reforma-do-maracana-teve-aditivos-suspeitose-gastos-em-duplicidade-diz-tce-ri.ghtml 
e auditorias realizadas pelos órgãos competentes ${ }^{126}$, as irregularidades praticadas teriam aumentado o custo das obras em $R \$ 211$ milhões, o que levou o Ministério Público a requerer que as empresas Odebrecht, Andrade Gutierrez e Delta Engenharia, integrantes do Consórcio Maracanã, vencedor da licitação, restituíssem $R \$ 200$ milhões ao erário fluminense. Dentre as principais irregularidades apontadas, estão termos aditivos suspeitos, realização de "jogo de planilhas"127, superfaturamentos, gastos em duplicidade, relevantes modificações entre os projetos básico e executivo, dentre outras. $O$ contrato teve 16 aditivos no total.

Além disso, a promotoria carioca apurou que teria havido irregularidade também no processo licitatório instaurado pelo Governo do Estado para escolha do consórcio responsável pela obra, com suposto favorecimento das empresas vencedoras e formação de cartel. A suspeita de favorecimento do Consórico Maracanã foi apontada também em delação de executivo da empresa Andrade Gutierrez, indicando a formação de um acordo para pagamento de propina ao Governo do Estado do Rio; esta foi, inclusive, uma das denúncias que levaram à prisão do ex-Governador Sérgio Cabral. Tais fatos acarretaram, além das sanções de natureza criminal, a propositura, em 2017, de ação civil pública para responsabilização dos envolvidos - servidores públicos, empresas favorecidas e executivos acusados da prática de atos de improbidade administrativa, contendo pleito voltado ao ressarcimento dos cofres públicos por parte dos responsáveis pelos prejuízos apurados.

O modelo econômico adotado pelo Governo do Estado para a reforma do Maracanã foi elaborado pela empresa IMX 9, segundo dados disponibilizados pela Secretaria da Fazenda do Rio de Janeiro ${ }^{128}$. A metodologia utilizada para qualificar a viabilidade do Projeto foi o método de Fluxo de Caixa Descontado. Segundo a IMX, o modelo econômico financeiro baseado no método citado foi elaborado em

\footnotetext{
${ }^{126}$ https://exame.abril.com.br/brasil/reforma-do-maracana-foi-superfaturada-em-r-211milhoes-diz-tce/

${ }^{127}$ Substituição de itens de maior valor por outros de menor valor, normalmente efetivada através de aditivo contratual.

${ }^{128} \mathrm{http}: / /$ www.fazenda.rj.gov.br/sefaz/ShowProperty?nodeld=\%2FUCMServer\%2FWCC224 508\%2F\%2FidcPrimaryFile\&revision=latestreleased
} 
reais $(R \$)$ constantes, descontando efeitos inflacionários, e projetado para 35 (trinta e cinco) anos (até 2047), sendo 2 (dois) anos para construção e 33 (trinta e três) para operação, com receitas iniciando em 2015 (terceiro ano da concessão).

As premissas econômico-financeiras utilizadas para suportar a viabilização do projeto foram: (a) contrapartida pública, na forma de outorga dos direitos de exploração comercial da área do complexo do Maracanã; e (b) dois dos principais times do Rio de Janeiro mandariam seus jogos no Maracanã, gerando o fluxo necessário à viabilidade do projeto. Para efeito deste estudo foram considerados como grandes clubes o Flamengo, o Fluminense, o Vasco e o Botafogo. Dentre os cenários analisados, ao considerar apenas um dos grandes clubes do Rio de Janeiro nas projeções, o projeto não se mostrou viável financeiramente. Segundo a IMX, sendo satisfeitas as condições básicas listadas, o investimento apresentaria um retorno real de aproximadamente $10,0 \%$ a.a. (TIR), o que demostraria que o projeto seria viável do ponto de vista econômico-financeiro por motivo de redução dos investimentos inicialmente previstos. 
Figura 15 - Comparação do Maracanã com maiores em despesas

\begin{tabular}{|c|c|c|c|c|}
\hline Nome & Dono & Esporte principal & Investimento público & Preço final \\
\hline Yankes & New York & Belse & RS2,4bilhoses & R\$3 \\
\hline Stadlum & Yankees & & $\begin{array}{l}\text { (Financiamento com } \\
\text { isenço de Juros) }\end{array}$ & bilhoes \\
\hline $\begin{array}{l}\text { Estadio } \\
\text { Olimpico } \\
\text { de Londres }\end{array}$ & $\begin{array}{l}\text { Autoridade } \\
\text { Olimplca } \\
\text { Britânica }\end{array}$ & $\begin{array}{l}\text { Atletismo } \\
\text { e Futebol }\end{array}$ & $\begin{array}{l}\text { RS } 1,55 \\
\text { bilhiso }\end{array}$ & $\begin{array}{l}\text { RS } 1,55 \\
\text { bilhato }\end{array}$ \\
\hline Maracand & $\begin{array}{l}\text { Governo } \\
\text { do Estado } \\
\text { do Rio de } \\
\text { Janeiro }\end{array}$ & Futebol & $\begin{array}{l}\text { RS } 1,45 \\
\text { bilhato }\end{array}$ & $\begin{array}{l}\text { RS } 1,45 \\
\text { bilhdo }\end{array}$ \\
\hline CitiFleld & $\begin{array}{l}\text { New York } \\
\text { Mets }\end{array}$ & Beisebol & $\begin{array}{l}\text { (Financiamento com } \\
\text { isencliode de juros) }\end{array}$ & $\begin{array}{l}\text { RS } 1,9 \\
\text { bilhato }\end{array}$ \\
\hline $\begin{array}{l}\text { Lucas OII } \\
\text { Stadium }\end{array}$ & $\begin{array}{l}\text { Indlanapolis } \\
\text { Colts }\end{array}$ & $\begin{array}{l}\text { Futebol } \\
\text { americano }\end{array}$ & $\begin{array}{l}\text { RS } 1.24 \\
\text { bilhato }\end{array}$ & $\begin{array}{l}\text { RS } 1,45 \\
\text { bilhato }\end{array}$ \\
\hline $\begin{array}{l}\text { Cowboys } \\
\text { Stadium }\end{array}$ & $\begin{array}{l}\text { Dallas } \\
\text { Cowboys }\end{array}$ & $\begin{array}{l}\text { Futebol } \\
\text { americano }\end{array}$ & $\begin{array}{l}\text { RS } 890 \\
\text { milhoes }\end{array}$ & $\begin{array}{l}\text { RS 2,4 } \\
\text { bilhoes }\end{array}$ \\
\hline Wembley & $\begin{array}{l}\text { Federacáo de } \\
\text { Futebol da } \\
\text { Inglaterra }\end{array}$ & Futebol & RS 480 milhøes & $\begin{array}{l}\text { RS 2,3 } \\
\text { bilhoes }\end{array}$ \\
\hline Levils & San Francisco & Futebol & R\$230 milhbes & \\
\hline Stadium & $49 \mathrm{ers}$ & americano & $\begin{array}{l}\text { Estadio deve ficar } \\
\text { pronto em } 2014\end{array}$ & bilhoses \\
\hline $\begin{array}{l}\text { MetUle } \\
\text { Stadlum }\end{array}$ & $\begin{array}{l}\text { New York } \\
\text { Glants e New } \\
\text { York Jets }\end{array}$ & $\begin{array}{l}\text { Futebol } \\
\text { americano }\end{array}$ & Zero & $\begin{array}{l}\text { R\$3.2 } \\
\text { bilhoes }\end{array}$ \\
\hline $\begin{array}{l}\text { Emirates } \\
\text { Stadlum }\end{array}$ & Arsenal & Futebol & Zero & $\begin{array}{l}\text { RS } 1,45 \\
\text { billhato }\end{array}$ \\
\hline
\end{tabular}

Fonte: (Extra Globo)

Os equívocos na construção do modelo de sustentação do estádio do Maracanã o levaram a ser um dos estádios com maiores custos existentes atualmente. 
Além disso, conforme noticiado pela imprensa em março de $2019^{129}$, em razão do cancelamento da concessão - segundo o Governo, o consório deixou de pagar a outorga, dando prejuízo de $\mathrm{R} \$ 38$ milhões, a Odebrecht cobra mais de $\mathrm{R} \$$ 200 milhões do Estado do Rio de Janeiro, o que pode gerar ainda mais prejuízos aos cofres estaduais.

Em síntese, depreende-se que o modelo adotado para reforma do Maracanã estádio público com dinheiro público e concessão à iniciativa privada, não foi capaz de superar as dificuldades amplamente conhecidas no Brasil quando se trata do manejo de recursos de origem pública: descaso, mau uso de verbas públicas, desvios de metas e finalidades não alcançadas, prejuízos incalculáveis ao erário e à sociedade civil como um todo.

\subsection{Morumbi}

O Morumbi, estádio do São Paulo Futebol Clube, entrou na disputa para ser o estádio do jogo inaugural e recepcionar os outros jogos na cidade, como já aduzido, escolhendo não se tornar um estádio-shopping, apropriado às exigências da FIFA; procurou atendê-las no mínimo necessário, por intermédio de reforma restrita, que não previa, por exemplo, cobertura dos setores de arquibancada nem cuidados maiores com segurança e conforto. Desejava manter a condição de grande estádio da cidade sem torná-lo estruturalmente um estádio multiuso, conformando-se em sediar shows e eventos não esportivos, pela capacidade de assentos, no modelo arcaico anterior, onde o público comparece pelo desejo de assistir ao espetáculo, sem receber atenção específica. Era o estádio-arquibancada que desejava ter eventos esportivos e não esportivos de estádio-shopping sem se adequar a isso. Foi uma opção que a diretoria de então insistiu em realizar.

Por conta das condições que levaram a embate político de seu presidente, Juvenal Juvêncio, com o então presidente da CBF, que representava a FIFA no Brasil para o evento da Copa do Mundo, o Morumbi foi liminarmente descartado. Porém, a opção de não se tornar um estádio-shopping provocou considerável

129 https://g1.globo.com/rj/rio-de-janeiro/noticia/2019/03/18/odebrecht-que-teve-concessaodo-maracana-cancelada-cobra-mais-de-r-200-milhoes-do-rj.ghtm 
perda financeira, pois o local deixou de sediar não só jogos da Copa, como também partidas importantes dos campeonatos no Brasil, deixando de alugar o campo para outros clubes que visavam a um maior número de espectadores, e perdendo ainda a condição de "casa de eventos" internacionais e nacionais, que proporcionaram renda substancial para o clube anteriormente a 2007.

O Morumbi foi o modelo que não entendeu o que estava ocorrendo na mudança da relação torcedor apaixonado-clube do coração para cliente-clube empresa. Não captou a entrada do futebol nos padrões da indústria cultural, passando a representar o clube que perdeu receita com o processo, exemplo oposto do que ocorreu com o Allianz Parque.

O presidente do São Paulo Futebol Clube à época, Juvenal Juvêncio, declarou: "Não tem Copa do Mundo de sucesso neste país que abstraia o Estado de São Paulo. Não existe Copa sem São Paulo, sem sua inteligência, força e estrutura. Portanto a abertura será aqui. E onde seria senão aquela casa sacrossanta do Morumbi?", decretou o dirigente sem temer nem mesmo as rigorosas exigências impostas pela FIFA para a execução do evento. "Todos os estádios sofrerão este ou aquele tipo de observação. O Morumbi, todos sabem, está muito à frente do segundo estádio deste país. Mas ele sofre críticas. Eu sequer consigo desvendar, ou talvez tenha meus pensamentos, mas não estão conclusos. Preciso de calma.", complementou, sem citar qual seria o segundo estádio do país em sua opinião.

Apesar das dúvidas sobre quais seriam os pontos criticados, Juvenal Juvêncio não tinha dúvidas de que a Copa do Mundo passararia pelo estádio do São Paulo Futebol Clube. "O Morumbi, não só pela importância física, mas também pela importância de São Paulo, de sua economia, rede hoteleira, do seu centro de cultura, do transporte de massa de qualidade e da rede hospitalar. A Copa estará em São Paulo na sua abertura", encerrou. Com efeito, a Copa esteve em São Paulo, mas não no Morumbi, pois o momento exigia outra visão, outro padrão, outro patamar. O desfecho conhecido foi a opção pela construção da Arena Corinthians para sediar o evento. 


\subsection{Reflexos da Copa do Mundo de 2014}

Conforme se denota da atual situação financeira dos clubes nacionais, com especial destaque àqueles citados a título de comparação com o modelo adotado pelo Palmeiras, explicitados anteriormente (Corinthians, Flamengo e São Paulo Futebol Clube), a matriz econômica de um clube pode ser imensamente fortalecida através da adoção de um novo modelo de estádio, capaz de gerar considerável receita sem realização de grandes despesas ou assunção de dívidas, com financiamento proveniente da iniciativa privada. De outro lado, se mal gerida, a construção de um estádio pode acarretar dívidas monumentais, perda de clientes e outras consequências nefastas para a gestão de qualquer agremiação.

Os dados a seguir colacionados (tabela 48) demonstram que, dos três estádios citados como comparação, o Maracanã, além de ter sido o mais caro, utilizou a maior soma em recursos públicos $-\mathrm{R} \$ 1,45$ bilhão:

Tabela 48 - Comparação dos estádios

\begin{tabular}{|c|c|c|c|}
\hline Allianz Parque & Estádio do Morumbi & Arena Corinthians & Maracanã \\
\hline Inauguração: 19/11/2014 & Inauguração: 02/10/1960 & Inauguração: 10/05/2014 & Inauguração: 16/06/1950 \\
\hline $\begin{array}{l}\text { Construção: out.2010 - } \\
\text { nov.2014 } \\
\text { Nome: Allianz Parque } \\
\text { Propriedade: Privada } \\
\text { Proprietário: S.E. Palmeiras } \\
\text { Administrador: WTorre } \\
\text { Properties Arenas AEG } \\
\text { (Gestão) } \\
\text { Mandante: S.E. Palmeiras } \\
\text { Custo: R\$ } 650 \text { milhões }\end{array}$ & $\begin{array}{l}\text { Construção: } 1952 \text { a } 1970 \\
\text { Nome: Cícero Pompeu de } \\
\text { Toledo } \\
\text { Propriedade: Privada } \\
\text { Proprietário: São Paulo FC } \\
\text { Administrador: São Paulo } \\
\text { FC } \\
\text { Mandante: São Paulo FC } \\
\text { Custo: US } \$ 70 \text { milhões (R } \$ \\
\text { 259.595,00) }\end{array}$ & $\begin{array}{l}\text { Construção: mai.2011- } \\
\text { abr.2014 } \\
\text { Nome: Arena Corinthians } \\
\text { Propriedade: Privada } \\
\text { Proprietário: Corinthians } \\
\text { Administrador: } \\
\text { Corinthians } \\
\text { Mandante: Corinthians } \\
\text { Custo: } R \$ 1,08 \text { bilhões }\end{array}$ & $\begin{array}{l}\text { Construção: 02/08/1948 } \\
\text { Nome: Estádio Jornalista } \\
\text { Mário Filho } \\
\text { Propriedade: Pública } \\
\text { Proprietário: Governo do } \\
\text { Estado do Rio de Janeiro } \\
\text { Administrador: } \\
\text { Consórcio Maracanã } \\
\text { Mandantes: Fluminense } \\
\text { FC Seleção Brasileira de } \\
\text { Futebol } \\
\text { Custo: } R \$ 1,5 \text { bilhões }\end{array}$ \\
\hline Capacidade: 43.713 & Capacidade: 77.011 & Capacidade: 47.605 & Capacidade: 78.838 \\
\hline $\begin{array}{c}\text { Intervenção do setor público? } \\
\text { Não }\end{array}$ & $\begin{array}{c}\text { Intervenção do setor público? } \\
\text { Sim } \\
\text { Custo: US\$ } 3 \text { milhões (R\$ } \\
11.125,00 \text { ) em recursos } \\
\text { públicos foram aplicados na } \\
\text { obra durante as décadas de } \\
50 \text { e } 60 .\end{array}$ & $\begin{array}{c}\text { Intervenção do setor } \\
\text { público? } \\
\text { Sim } \\
\text { Custo: } \mathrm{R} \$ 420 \text { milhões } \\
\text { da Prefeitura. }\end{array}$ & $\begin{array}{c}\text { Intervenção do setor } \\
\text { público? } \\
\text { Sim } \\
\text { Custo: } \mathrm{R} \$ 1,45 \text { bilhão em } \\
\text { recursos públicos }\end{array}$ \\
\hline
\end{tabular}

Fonte: Jornal Estadão - https://esportes.estadao.com.br - Acesso em 22/05/2018 
O custo total de construção ou reforma dos 12 estádios para o Mundial de 2014 foi de $R$ \$ 8,384 bilhões, segundo balanço final do Grupo Executivo da Copa de 2014, órgão do governo federal ${ }^{130}$. Os 3 estádios mais caros - Arena Corinthians, Mané Garrincha e Maracanã, correspondem a $42 \%$ desse valor. Ao contrário do que foi propagado quando o Brasil foi escolhido para sediar a Copa de 2014, houve poquíssimo investimento privado nos gastos com as arenas para o mundial: apenas $7,2 \%$. Segundo o mencionado balanço final publicado pelo governo federal acerca dos custos do Mundial, os governos locais contribuíram com $47 \%$ dos recursos, e os restantes $45,8 \%$ foram objeto de financiamento com recursos federais, em sua maioria do BNDES.

\subsubsection{Evolução das receitas dos clubes brasileiros}

Os gráficos a seguir colacionados demonstram como evoluíram as receitas dos principais clubes brasileiros a partir de 2015, primeiro ano após a realização da Copa:

130 https://iogoslimpos.ethos.org.br/destaques/quanto-custaram-os-estadios-da-copa-2014/ acesso em 22/05/2018 
Gráfico 13 - Cotas de TV 2016-2015 (milhões R\$)

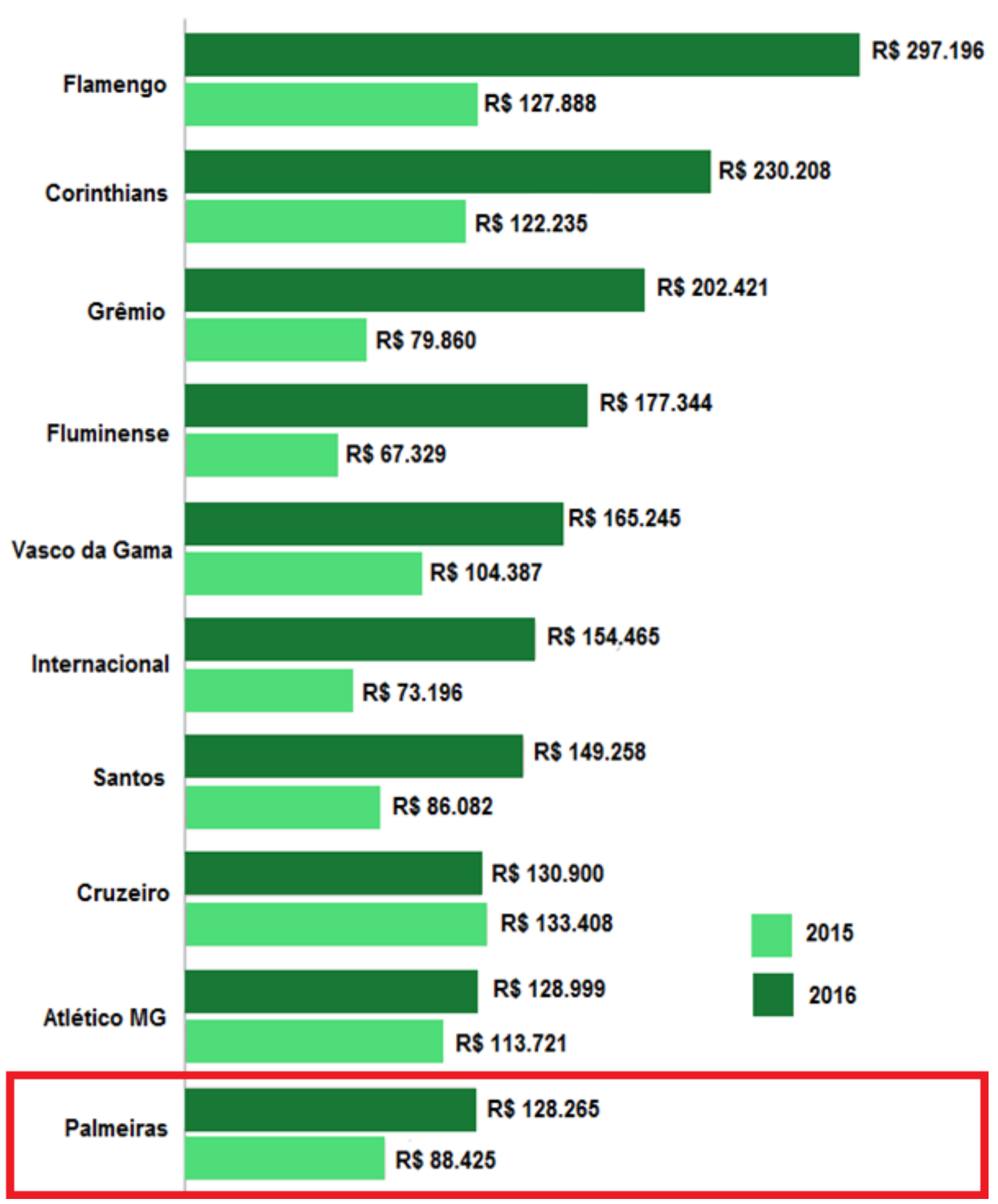

Fonte: www.bdo.com.br (BDO RCS Auditores Independentes)acesso 25/7/2018 
Gráfico 14 - Patrocínio e Publicidade 2016 - 2015 (milhões R\$)

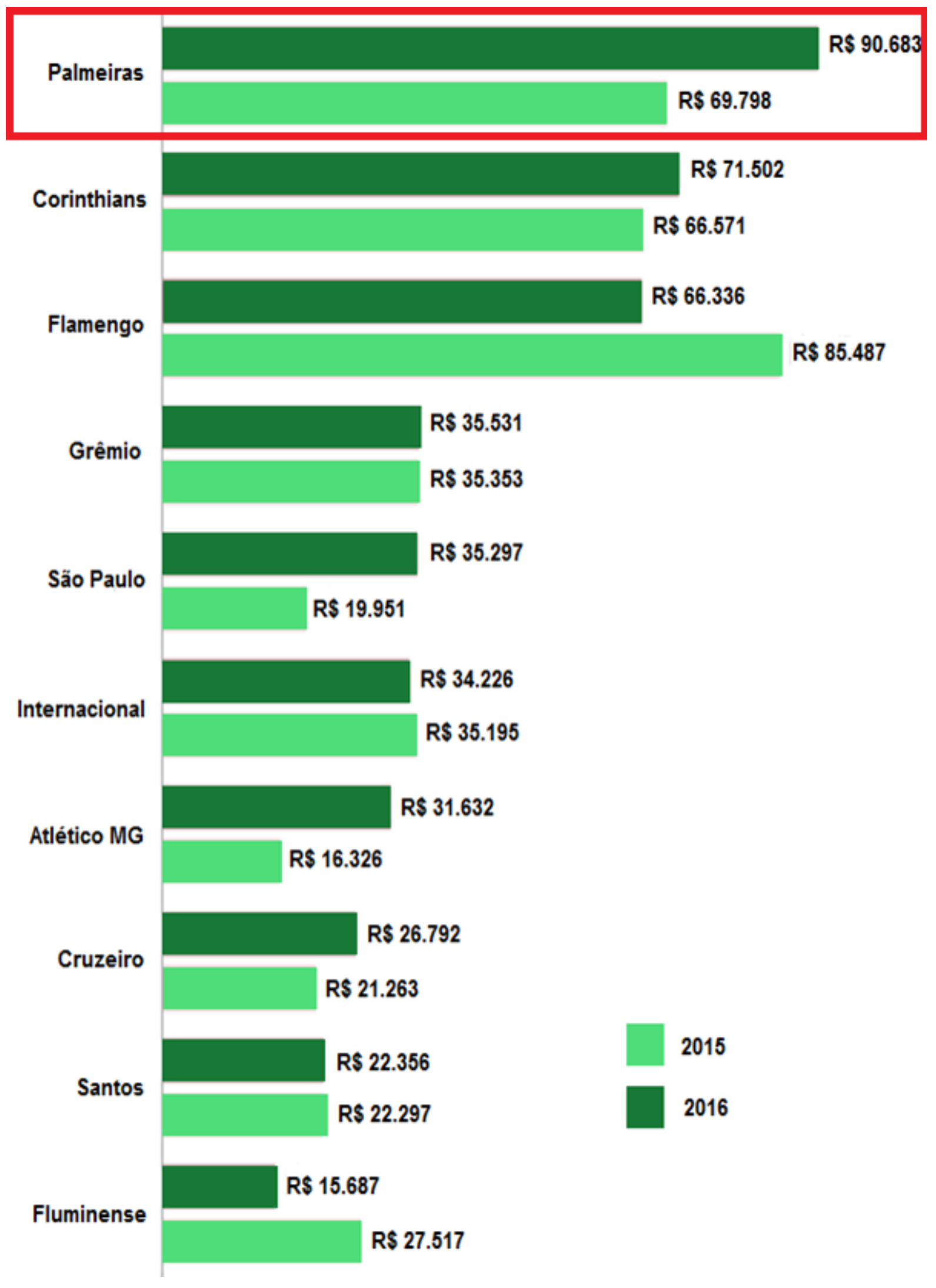

Fonte: www.bdo.com.br (BDO RCS Auditores Independentes)acesso 25/7/2018 
Gráfico 15 - Transferências de Atletas 2016 - 2015 (milhões R\$)

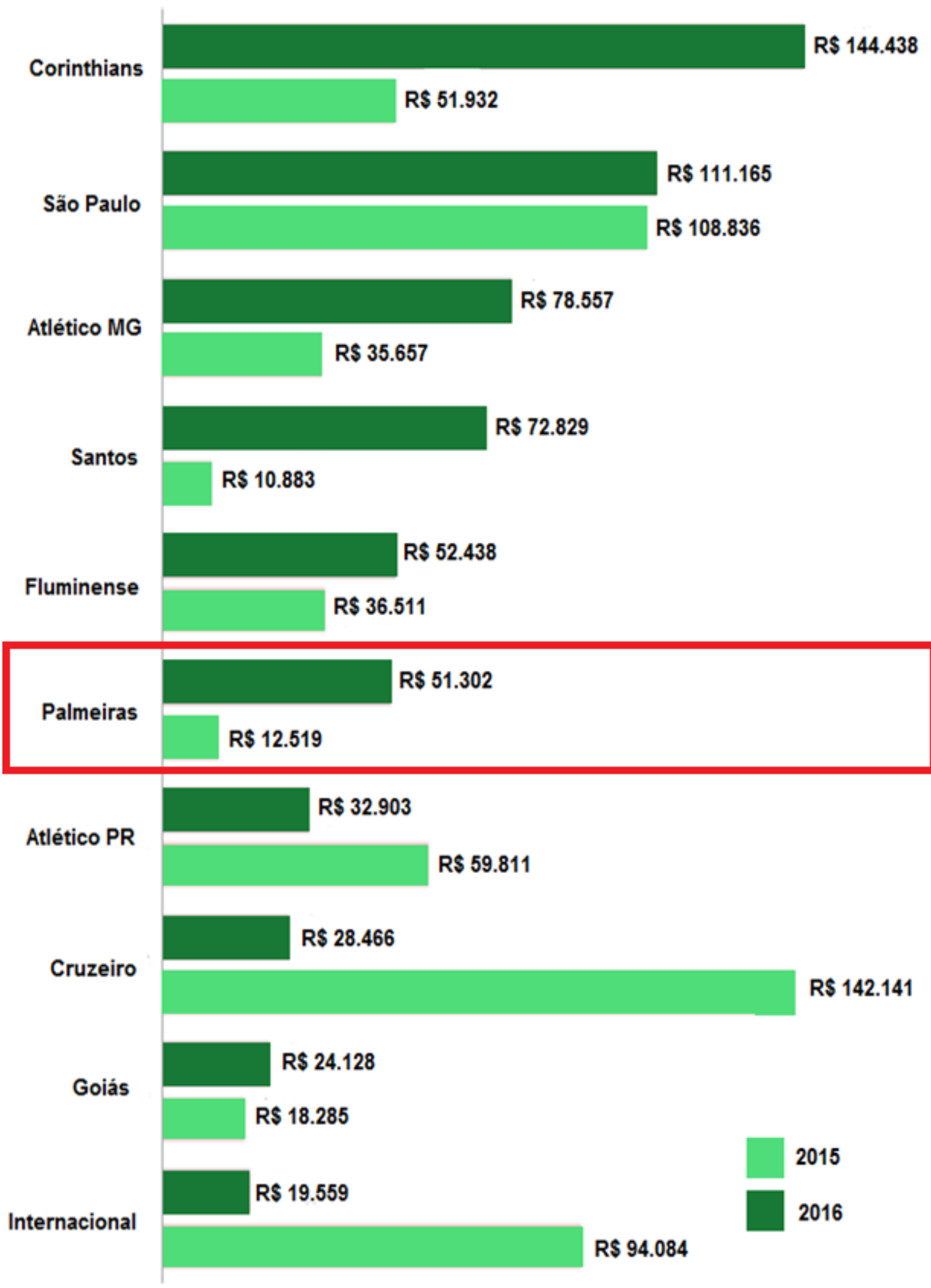

Fonte: www.bdo.com.br (BDO RCS Auditores Independentes)acesso 25/7/2018 
Gráfico 16 - Clube Social e Esporte Amador 2016 - 2015 (milhões R\$)

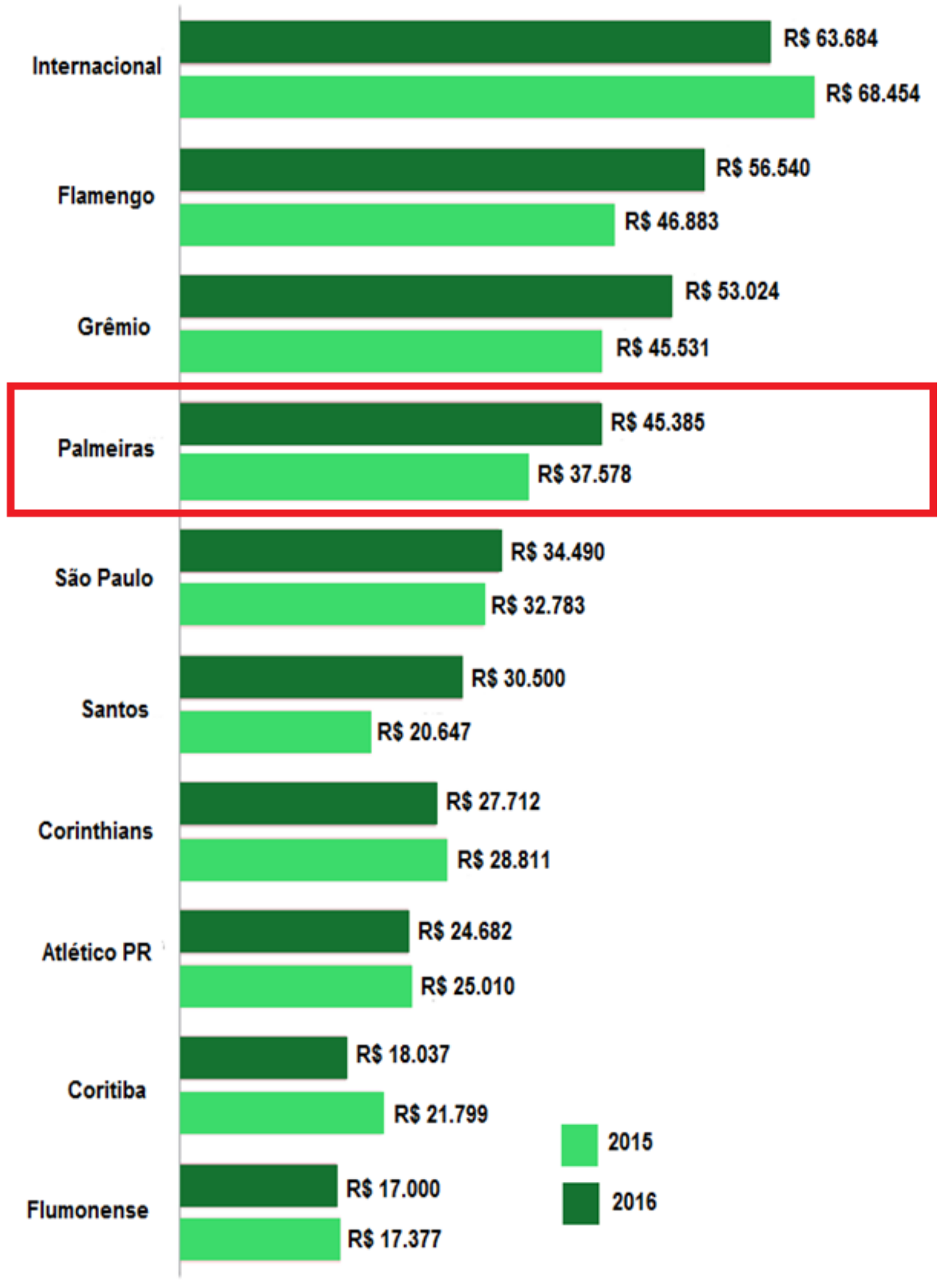

Fonte: www.bdo.com.br (BDO RCS Auditores Independentes) acesso 25/7/2018 
Gráfico 17 - Bilheteria 2016 - 2015 (milhões R\$)

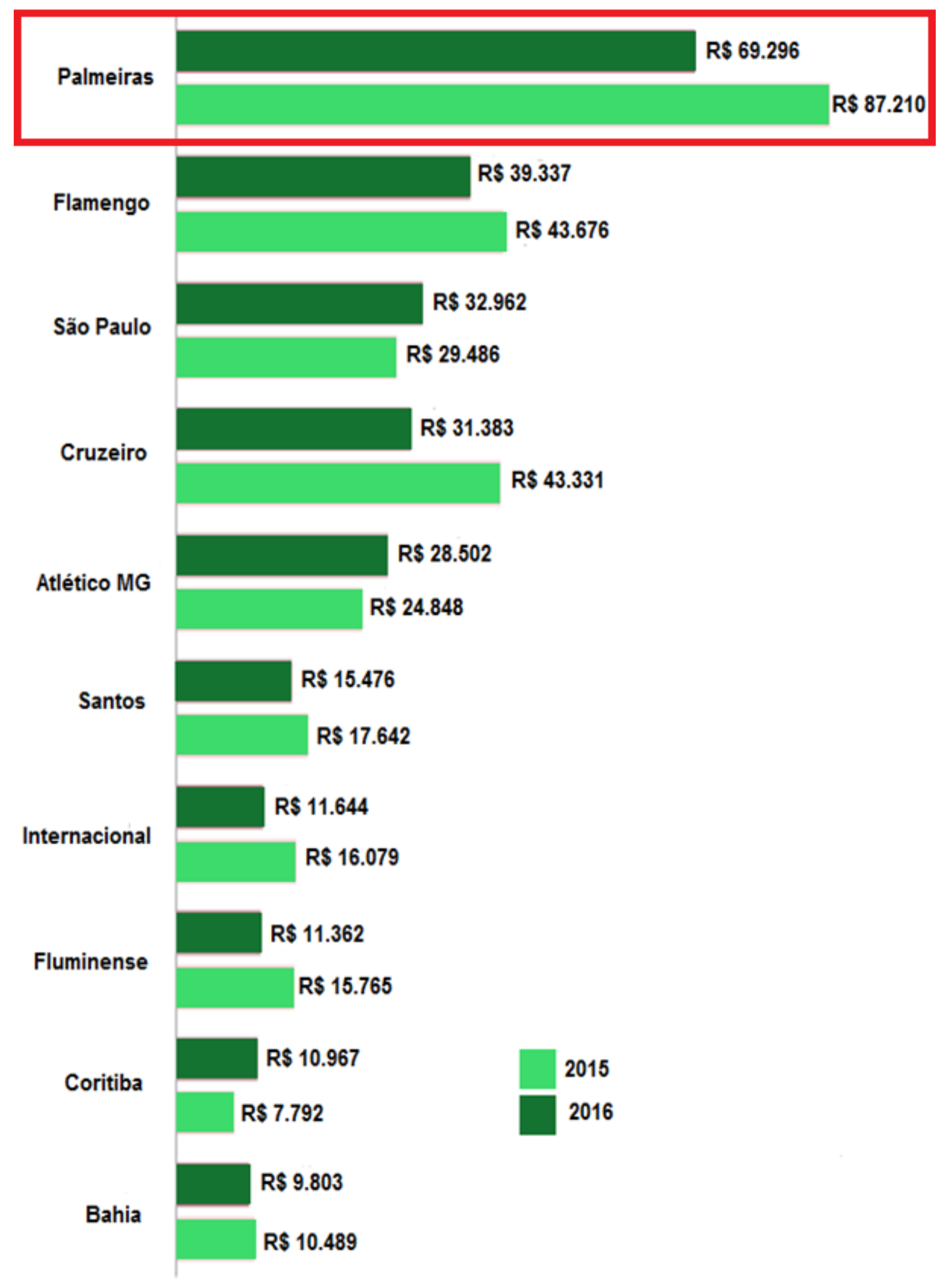

Fonte: www.bdo.com.br (BDO RCS Auditores Independentes) acesso 25/7/2018 
6.4.2. Ranking das Receitas: 22 Clubes Brasileiros

A corroborar todo o exposto, especificamente no que concerne ao grande salto para a independência econômico-financeira alcançado pela Sociedade Esportiva Palmeiras em decorrência do modelo adotado para construção do Allianz Parque, nota-se que em 2017 o clube foi o que obteve a segunda maior receita do país, atrás apenas do Flamengo:

Tabela 49 - Receita Total / Clubes (em R\$ mil)

\begin{tabular}{|c|l|c|c|c|c|}
\hline $\begin{array}{c}\text { RK } \\
\mathbf{2 0 1 7}\end{array}$ & \multicolumn{1}{|c|}{ Clubes } & UF & $\begin{array}{c}\text { Receita Total } \\
\mathbf{2 0 1 7}\end{array}$ & $\begin{array}{c}\text { Receita Total } \\
\mathbf{2 0 1 6}\end{array}$ & $\begin{array}{c}\text { Variação } \\
\mathbf{2 0 1 5 - 2 0 1 6}\end{array}$ \\
\hline 1 & Flamengo & RJ & 648.712 & 510.074 & $27 \%$ \\
\hline $\mathbf{2}$ & Palmeiras & SP & $\mathbf{5 0 3 . 6 8 2}$ & $\mathbf{4 6 8 . 6 4 4}$ & $\mathbf{7 \%}$ \\
\hline 3 & São Paulo & SP & 482.595 & 393.373 & $23 \%$ \\
\hline 4 & Corinthians & SP & 391.242 & 485.468 & $-19 \%$ \\
\hline 5 & Grêmio & RS & 364.582 & 330.366 & $10 \%$ \\
\hline 6 & Cruzeiro & MG & 344.315 & 238.360 & $44 \%$ \\
\hline 7 & Atlético - MG & MG & 311.365 & 316.312 & $-2 \%$ \\
\hline 8 & Santos & SP & 287.002 & 295.839 & $-3 \%$ \\
\hline 9 & Botafogo & RJ & 264.302 & 160.118 & $65 \%$ \\
\hline 10 & Internacional & RS & 245.915 & 292.651 & $-16 \%$ \\
\hline 11 & Fluminense & RJ & 212.156 & 293.194 & $-28 \%$ \\
\hline 12 & Vasco da Gama & RJ & 191.506 & 213.320 & $-10 \%$ \\
\hline 13 & Atlético - PR & PR & 161.285 & 164.075 & $-2 \%$ \\
\hline 14 & Coritiba & PR & 119.098 & 109.836 & $8 \%$ \\
\hline 15 & Bahia & BA & 104.898 & 120.708 & $-13 \%$ \\
\hline 16 & Chapecoense & SC & 99.802 & 67.195 & $49 \%$ \\
\hline 17 & Sport & PE & 92.560 & 121.422 & $-24 \%$ \\
\hline 18 & Vitória & BA & 88.071 & 111.976 & $-21 \%$ \\
\hline 19 & Ponte Preta & SP & 68.768 & 64.579 & $6 \%$ \\
\hline 20 & Goiás & GO & 64.768 & 90.406 & $-28 \%$ \\
\hline 21 & América & MG & 38.902 & 59.529 & $-35 \%$ \\
\hline 22 & Figueirense & SC & 26.533 & 70.891 & $-63 \%$ \\
\hline
\end{tabular}

Fonte: www.bdo.com.br (BDO RCS Auditores Independentes) acesso 25/7/2018 


\subsubsection{Maiores Rendas}

No que concerne às partidas com maiores rendas realizadas no ano de 2018, a tabela 38 demonstra que o Palmeiras consta nas cinco primeiras colocadas:

Tabela 50 - Maiores rendas do Brasil em 2018

\begin{tabular}{|c|c|c|c|c|c|}
\hline & Jogo & Renda & Público pagante & Campeonato & Data \\
\hline $1^{\circ}$ & Palmeiras $1 \times 1$ Boca Juniors & $\mathrm{R} \$ 4.426 .402$ & 37.192 & Libertadores & $11 / 04$ \\
\hline $2^{\circ}$ & Palmeiras $0 \times 1$ Corinthians & $\mathrm{R} \$ 4.001 .278$ & 41.227 & Paulista & 08/04 \\
\hline $3^{\circ}$ & Corinthians $0 \times 1$ Palmeiras & $\mathrm{R} \$ 3.182 .924$ & 43.535 & Paulista & $31 / 03$ \\
\hline $4^{\circ}$ & Palmeiras 2 x 0 Alianza Lima & $\mathrm{R} \$ 2.903 .371$ & 30.456 & Libertadores & $03 / 04$ \\
\hline $5^{\circ}$ & Palmeiras $2 \times 1$ Santos & $\mathrm{R} \$ 2.821 .680$ & 37.867 & Paulista & $04 / 02$ \\
\hline
\end{tabular}

Fonte: Globo Esporte - https://globoesporte.globo.com - Acesso em 10/10/2018

Além disso, o clube foi o que obteve a maior renda líquida entre os 20 clubes da Série A do Campeonato Brasileiro de 2018: 
Tabela 51 - Renda Líquida dos 20 Clubes da Série A Campeonato Brasileiro 2018

\begin{tabular}{|c|c|}
\hline CLUBE & RENDA LÍQUIDA \\
\hline Palmeiras & R\$ 23,75 milhões \\
\hline São Paulo & $\mathrm{R} \$ 16,72$ milhões \\
\hline Corinthians & $\mathrm{R} \$ 16,01$ milhões \\
\hline Grêmio & $\mathrm{R} \$ 11,61$ milhões \\
\hline Internacional & $\mathrm{R} \$ 11,17$ milhões \\
\hline Ceará & $\mathrm{R} \$ 5,04$ milhões \\
\hline Atlético-MG & $\mathrm{R} \$ 3,86$ milhões \\
\hline Flamengo & $\mathrm{R} \$ 3,38$ milhões \\
\hline Chapecoense & $\mathrm{R} \$ 3,37$ milhões \\
\hline Bahia & $\mathrm{R} \$ 3,18$ milhões \\
\hline Cruzeiro & $\mathrm{R} \$ 2,40$ milhões \\
\hline Paraná Clube & $\mathrm{R} \$ 2,38$ milhões \\
\hline Sport & $\mathrm{R} \$ 2,09$ milhões \\
\hline Santos & $\mathrm{R} \$ 1,07$ milhões \\
\hline Atletico Paranaense & $\mathrm{R} \$ 940,4 \mathrm{mil}$ \\
\hline Vasco da Gama & $\mathrm{R} \$ 921,4 \mathrm{mil}$ \\
\hline Vitória & $\mathrm{R} \$ 518,6 \mathrm{mil}$ \\
\hline América-MG & - $\mathrm{R} \$ 1,03$ milhões \\
\hline Botafogo & - $\mathrm{R} \$ 3,28$ milhões \\
\hline Fluminense & - R\$3,53 milhões \\
\hline
\end{tabular}

Fonte: https://www.espn.com.br/futebol/artigo/_/id/5050852/brasileirao-arrecadou-quase-r-220milhoes-em-bilheteria-veja-quanto-disso-ficou-para-o-seu-clube (acesso em 31/01/2020)

Com o Mapa Estratégico proposto no Capítulo V e as comparações entre os estádios apresentadas no presente Capítulo $\mathrm{VI}$, chegamos à conclusão desse trabalho. É preciso considerar toda a sua complexidade, o fato de o Brasil estar recém avançando na Economia do Futebol, enumerar os fatores de risco e aquilo que tratamos com cuidado especial: a transformação do vínculo do torcedor, de apaixonado para cliente, um corolário natural da economia do futebol envolta pela indústria do entretenimento. Sem nunca olvidar que, mesmo assim, vários torcedores se mantêm apaixonados e dispostos a comparecerem em qualquer estádio para assistir o clube do coração. Trata-se de considerar tudo isso, diante da intrincada teia das relações sociais e idiossincrasias humanas. A seguir, nossa conclusão procura examinar o todo, considerando a dificuldade dessa trajetória. 


\section{CONCLUSÃO}

Este trabalho se propôs a argumentar, ponderar e demonstrar que existe um caminho para que os clubes consigam construir uma matriz econômica estável, previsível e saudável, a permiti-los mais do que sobreviver, a contemplar projetos de crescimento e expansão. A história econômica dos clubes no Brasil, mesmo os considerados de grande porte pelo número de torcedores, receitas e/ou tradição, aponta trajeto desalentador, e por isso a tese emerge com vigor pelo surgimento de uma perspectiva de encantamento e sucesso com a construção, no Brasil, dos estádios suscitados pela Copa do Mundo de 2014.

Nem todos os clubes alcançarão as conjunções que o Allianz Parque proporcionou para a Sociedade Esportiva Palmeiras. Durante 0 trabalho enunciamos as condições específicas desse projeto, estrutura central da tese, com todas as nuances e contingências. Contudo, é possível descortinar que qualquer clube que dispute as séries $\mathrm{A}$ ou $\mathrm{B}$ do campeonato brasileiro gerido pela $\mathrm{CBF}$, pode evoluir a respectiva matriz econômica por intermédio da gestão do estádio que utiliza para sediar seus jogos. Ou seja, a inserção da administração do estádio no arcabouço econômico-financeiro é aplicável a qualquer um deles e, conforme as circunstâncias, pode se estender a outros clubes fora do rol aludido. Então surge a contribuição desejada do trabalho: a transformação do estádio, antes um elemento com saldo negativo, com despesas maiores do que as receitas, ou, no máximo, com saldo positivo modesto, a não se constituir em objeto prioritário na matriz econômica do clube, em ativo financeiro. $\mathrm{O}$ que era historicamente um passivo ou um ativo irrelevante passou a ser, por conta de todas as mudanças mencionadas ao longo do trabalho, um ativo importante, a depender do avistamento do significado e da boa governança estabelecida. $O$ trabalho procurou distinguir os requisitos necessários e enumerar os riscos para o insucesso do processo.

O futebol brasileiro gastou muitos anos desperdiçando oportunidades de estabilizar seus clubes, sobretudo os mais tradicionais, com equívocos específicos, mas não só, adicionou a eles vícios e erros que se sucederam em nossa economia e políticas públicas. Este é outro aspecto que a tese busca trazer como inovação, 
uma vez que o fracasso financeiro dos clubes é comumente apresentado como produto apenas da insensatez dos respectivos dirigentes, em simplificação profundamente equivocada, e que tem contribuído para a perenização do malogro. O futebol não é uma ilha, mas, muitas vezes, é tratado pelos seus adeptos dessa forma restrita. Ele é envolto por todas as relações econômicas e sociais do país, pela história e cultura, pelo ambiente político, fatores que costumam ser menoscabados nas análises.

A história econômica que se inicia como atividade de entretenimento exclusivamente amadora, evolui lentamente para exercício semiamador com presença de mecenas e contribuições não sistêmicas, além de contemplar procedimentos exóticos como a utilização das receitas dos bailes de Carnaval na Sociedade Esportiva Palmeiras para a compra de jogadores, recebe um impulso profissionalizante destacado com o advento da TV, sobretudo as transmissões ao vivo e a entrada de patrocinadores mais robustos, e pela dimensão econômica que ganha com a TV, catapultada pela assistência que veio da Ásia, a indústria de marketing dominando a organização dos eventos da FIFA, com a indução da globalização e, em especial, do Consenso de Washington, alcança o estágio atual de uma atividade econômica que mais movimenta recursos no mundo.

Todo esse processo caminhou com lenta adequação dos clubes brasileiros, e os estádios, embora ainda não os tenham colocado no patamar que eles podem atingir, abriram perspectiva imensa, desafiadora e passível de alterar a matriz econômica das entidades. Os dados coletados e expostos desvendam um horizonte provocante, tentador, a soar como um repto ao qual os clubes devem responder.

Se lançarmos uma esteira-âncora em direção ao passado e arrastarmô-la ao presente no processo histórico do nosso futebol, como sugere nosso orientador, não desfrutaremos de muitos exemplos promissores de modernidade administrativa nem de tentativas em busca de modelos de gestão sustentáveis, que proporcionassem aos clubes a matriz econômica sustentável e estável, a impeli-los a um futuro que os coloque em patamar de destaque no cenário de conquistas nacionais e no cenário internacional. 
Os clubes não procuraram a obtenção de ativo que permitisse receitas previsíveis e autônomas. Os estádios surgiram em decorrência das exigências da FIFA para a Copa do Mundo de 2014. Foi um movimento indireto, vindo do exterior, com o objetivo de assegurar padrões que, sobretudo, permitissem a obtenção de resultado financeiro melhor no evento de caráter mundial. $\mathrm{O}$ futebol brasileiro resistiu à modernidade como poucos.

Importante ressaltar na conclusão do trabalho, que o futebol tem uma particularidade que prejudica imensamente sua análise e coleta de dados: o clubismo irracional. Torcedores não aceitam críticas negativas, mesmo que construtivas, de nenhuma forma. Imaginam que, vindas de qualquer analista que não seja torcedor do mesmo clube, tenham o objetivo único de menosprezar a agremiação. E quando são geradas dentro do grupo de correligionários, muitas vezes são atribuídas a questões políticas internas e repelidas sem exame prévio sequer. Tal conduta dificulta muito a investigação de causas e a formação de juízos mais aprofundados. O torcedor e os conselheiros julgam a crítica como uma ameaça, e ao não se lançarem a escrutínio cuidadoso contribuem com o agravamento das falhas e a persistência dos erros. Outro viés a dificultar o trabalho de pesquisa é a leniência que torcedores e conselheiros efetuam com relação aos equívocos e desvios quando os respectivos clubes conquistam algum título. Tudo é perdoado e não há distanciamento entre a avaliação crítica e o objeto, resultando na desconsideração absoluta dos erros do sistema, sobretudo os relativos à gestão.

O futebol requer um campo de discussão mais isento e esse foi um dos motivos dessa tese: buscar trazer à luz todos os fatores envolvidos no processo de formação de uma matriz econômica sustentável e alvissareira, com horizonte amplo e factível, procurando isolar os elementos conjunturais ou fortuitos que levam à ilusão de sucesso por conta de conquistas memoráveis, mas não replicáveis.

O Allianz Parque foi o catalisador da ação que resultou na matriz econômica. No início de sua construção não vislumbrava tal objetivo. A constelação de alguns fatores, estádios padrão FIFA, um investidor que perseguia a lucratividade do 
empreendimento, um grupo de planejamento que se baseou na experiência da Amsterdam Arena, com o viés de espetáculo incutido, o empuxo da economia do futebol que se avultava, a transição do torcedor-apaixonado para o torcedor-cliente embalado pela indústria do entretenimento, tudo isso somado e devidamente ponderado, levou à nova realidade. Não foi um desenrolar absolutamente consciente. Todavia, as circustâncias contaram e conspiraram para o surgimento da matriz econômica estável que buscávamos na questão-chave suscitada na Introdução. A independência econômica do clube não foi rastreada desde logo, quando o projeto do estádio se apresentou. Contudo, a perspectiva de se ligar utilização da arena para jogos de futebol com outros usos que proporcionassem lucro e fizessem a transformação do estádio, de um elemento que fora dos dias de jogos é um passivo, especialmente por conta dos custos de manutenção, em ativo que traz receita em vários dias em que não ocorrem as partidas, auxiliou na pavimentação do caminho para o resultado apontado.

O Allianz Parque fez a Sociedade Esportiva Palmeiras divisar horizonte anteriormente jamais imaginado, provavelmente sequer cultivado como sonho: a perspectiva de independência econômica, da estabilidade financeira, conforme os dados coletados anunciam. O percentual de receitas procedentes do estádio, superando o faturamento com a venda dos direitos de transmissão por TV, sobrepujando os patrocínios espelha a conclusão desse trabalho. O estádio operou como ativo-âncora da construção da matriz econômica, trabalhando como forte fundação e acedendo a oportunidade de o clube negociar com mais desembaraço e independência outros ativos, inclusive os direitos de transmissão acima referidos.

Contudo, importante notar que há diversos fatores que devem ser escrutinados com cuidado para que o estádio se transforme em ativo realmente edificante, sólido, estável e contínuo. Vários aspectos se sucederam na implantação do Allianz Parque que trouxeram dificuldades e problemas, a saber:

a) não houve cuidado com a formalização da harmonia entre as programações dos eventos não esportivos que ocupariam o estádio e o calendário futebolístico; 
b) ocorreu imprecisão no texto que definia o número de cadeiras que seriam de propriedade da WTorre;

c) não se tratou de criar uma instância que pudesse resolver discordâncias na dinâmica do acordo, de modo a reduzir conflitos que poderiam chegar a disputas judiciais;

d) não se elaborou um plano de negócios que levasse em conta a frequência do torcedor com menor poder aquisitivo nem a participação do sócio-torcedor;

e) as áreas do clube que foram suprimidas pela reconstrução do estádio e alocadas em prédio a ser construído pela WTorre como forma de compensação não foram definidas e especificadas, suscitando outro litígio que afetou a relação entre as partes;

f) ocorreu um lapso de tempo muito grande entre a assinatura do contrato e o início da obra, a provocar necessidade de uma retirratificação do contrato que prejudicou o andamento da obra e causou insegurança no projeto.

O conjunto acima mencionado ocasionou uma série de conflitos prejudiciais ao desempenho econômico e administrativo, afetando tanto a Sociedade Esportiva Palmeiras como a WTorre.

A programação dos shows do porte que o Allianz Parque ostenta tem prazo de antecedência de dois a três anos por conta da agenda dos artistas eleitos, enquanto a agenda do futebol se dá ano a ano, o que não permite saber quando o clube utilizará o respectivo estádio para os jogos oficiais. A forma açodada por conta do risco de inviabilização, como se configurou a aprovação do acordo nos órgãos de gestão e deliberação do clube, propiciou indefinição sobre o número de cadeiras que ficariam na posse da WTorre, ocasionando disputa judicial longa e paralisante, com enorme desgaste entre os parceiros; a ausência de uma instância conjunta amigável com força contratual a buscar pontos em comum, diminuindo o campo de confrontação tornou mais aguda a disputa na arbitragem que se sucedeu, com os naturais recursos jurídicos que estenderam a desinteligência; a irreflexão sobre a forma como o torcedor ocuparia o estádio, tanto os originários do programa Avanti para sócios-torcedores, que adquirem vantagens não só com a 
frequência como na preferência, ocasionando demanda específica, como o torcedor não incluso no aludido programa, sobretudo aquele com menor renda, levando à elitização do estádio, com reclamações profundas e à existência de um grande contingente de torcedores apaixonados que, até hoje, nunca tiveram acesso ao Allianz Parque. O negligenciar da política interna, a desconsideração do fato, induzindo a consolidação de forças que se opunham à construção, são tópicos e particularidades que merecem um estudo cuidadoso para a redução de referências lesivas e ou postergatórias.

Não é só o estádio que pode desempenhar este papel de plataforma para a matriz econômica de independência, as idiossincrasias de cada entidade e as circunstâncias podem produzir outros; o que é fundamental é o estabelecimento de um ou dois ativos que exerçam tal função e se desenvolvam sob controle da direção do clube, porém com normas estáveis e que assegurem a não interferência dos fatores pessoais intangíveis relatados em capítulo anterior. A formação de ativos endógenos com gestão independente dos financiadores tradicionais do futebol como patrocinadores, detentores de direitos de transmissão por TV ou streaming, empresários e agentes de atletas, federações e CBF é fundamental e imprescindível. O clube não pode ficar à mercê deles, negociando em inferioridade e pressionado por dívidas e obrigações.De qualquer forma, mesmo aquele clube que não possua contingente de torcedores suficiente para tornar o estádio ativo principal, deve otimizar a utilização da respectiva arena de jogos para que ela tenha receita líquida positiva. Isoladamente, o estádio pode não constituir elemento suficiente para a independência, mas sempre deverá fazer parte do conjunto de ativos formadores dessa autonomia.

Além das limitações originadas por falhas produzidas pela imperícia de gestão ou desconhecimento do todo, o modelo do Allianz Parque como âncora da matriz econômica apresenta restrições exógenas ao gerenciamento, que devemos levar em consideração como as particularidades na constituição dos balanços e eventuais imprecisões no lançamento de rendas auferidas, que podem ter contestações judiciais e diferenças entre a forma de apropriação da Sociedade Esportiva Palmeiras e da empresa responsável pela gestão do Allianz Parque, a Real Arenas, e pendências que ainda seguem em discussão. Os clubes nunca 
tomaram a sério o processo de elaboração e tratamento dos dados, seja nas receitas auferidas, seja nas despesas ocorridas, passando a cuidar disso com mais atenção após a obrigatoriedade explicitada pelo Estatuto do Torcedor e Lei de Responsabilização do Futebol que fixaram parâmetros normativos antes inexistentes. A Lei Pelé estabeleceu a compulsoriedade da publicação de balanços, mas não definiu forma nem explicitou as penalidades pelo não cumprimento, proporcionando publicações resumidas e não totalmente claras. A exclusividade do Allianz Parque, com todas as respectivas idiossincrasias, também é fator limitante a ser observado.

Outra observação capital encontrada no trabalho realizado é o arcabouço institucional e a engenharia financeira da concretização do estádio como fonte. No caso do Maracanã, tivemos um estádio pertencente ao poder público - governo do Estado do Rio de Janeiro, com parte de dinheiro público e gestor privado que concorreu a certame licitatório, sem que houvesse clube responsável direto pelo mando de jogos no estádio definido. Há problemas que até hoje estão por se resolver. De nada adiantou o estádio do Sport Clube Corinthians Paulista para a alforria econômica da agremiação, por conta da engenharia financeira e do plano de negócios aplicados. O empreendimento foi idealizado como a resposta ao sonho de ter um estádio e não como base de matriz econômica. Tratou-se de alternativa onde o estádio é privado, mas houve a injeção de dinheiro público, através dos mencionados Certificados de Incentivo ao Desenvolvimento - CIDs, e empréstimo tomado diante de banco estatal - a Caixa Econômica Federal, em esfera de governo diferenciada do dinheiro municipal, com criação de fundo onde o clube é o último beneficiário e a constrtutora tem a prioridade. O Corinthians não se apropria da receita de bilheteria, pois esta é remetida ao Fundo Proprietário do estádio até que as dívidas referentes à construção e ao empréstimo sejam saldadas.

$\mathrm{Na}$ formação da matriz de independência, a receita de bilheteria deve ser direta e imediatamente apropriada pelo clube e o estádio necessita estar de acordo com exigências do novo torcedor, o torcedor-cliente, que o frequenta. O São Paulo Futebol Clube não reformou o estádio Cícero Pompeu de Toledo, o Morumbi, e embora seja proprietário das receitas, as têm diminuídas pelas condições do local. É um estádio que não se adequou aos novos tempos, necessitando lançar mão de 
preços baixos para conseguir lotação considerável. Outro fator relevante é que o estádio produza receitas além dos dias de jogos, e, para isso, é mais importante ainda que possua instalações modernas e confortáveis. No estádio do São Paulo F.C. parte significativa dos espectadores se submete ao risco de chuva e intempéries diminuindo a atratividade.Quer dizer, não basta ser um estádio, cabe se constituir num complexo gerador de receitas capaz de alcançar rentabilidade em todas as alternativas de utilizaçãoe isso leva em conta a qualidade das instalações.O estádio-arquibancada não consegue atender às demandas atuais. Além disso, a gestão dessa estrutura toda se sobreleva na obtenção do resultado colimado. Ela requer profissionalismo e cuidado com o cliente, o que nem sempre é levado em conta pelo clube proprietário acostumado com o torcedor-apaixonado que frequentava o estádio sem exigências.

Qualquer que seja o ativo que sirva de base para a matriz econômica independente é necessário estar adaptado à nova economia do futebol, que, por sua vez, nunca se desborda da economia nacional e da internacional em conexões que não podem ser descuidadas. A Economia do Futebol é uma realidade e não pode ser ignorada. Hoje, alguns clubes têm ações nas bolsas de valores dos respectivos países, fundos de "private equity"' são proprietários de clubes tradicionais, investidores particulares assumiram o controle de outros como no casos referidos do Milan e Internazionale, entre tantos, os petrodólares inundam o mundo do futebol com a participação de sheiks e membros de famílias reais riquíssimas, o patrocínio assumiu colossal dimensão, com clubes da Premier League inglesa, a liga mais rica, sendo patrocinados por poderosos bancos asiáticos por conta da audiência de TV que chega ao continente oriental, os passes dos atletas atingem valores estratosféricos e se enquadram nos conceitos de valor de uso e valor de troca, o valor financeiro movimentado é muito significativo. Não é possível passar ao largo nem cogitar os tempos românticos de outrora, ainda que possam trazer uma brisa poética do passado, com atletas que construíam vínculo afetivo inarredável com a camisa que vestiam. Tempos belos, tempos vencidos pela nova dinâmica da economia, da globalização, da criação de valores econômicos novos. Não existe perspectiva de sucesso para grandes clubes sem que percebam e se insiram nessa realidade. Contudo, também não é plausível 
abandonar ou sequer negligenciar o aspecto envolto pela paixão e fidelidade do torcedor, fatores que movem e sustentam esta nova economia.

O Allianz Parque é um exemplo dessa nova economia que os tempos mais recentes, em especial os anos do século $X X I$, transformaram em realidade inexorável. A economia do futebol está ligada inextricavelmente à indústria do entretenimento, que tem base na indústria cultural. Não é possível haver o deslinde entre economia do futebol e indústria do entretenimento e as respectivas consequências na formação das receitas da SEP.

Todavia, cabe aos clubes cuidarem do acesso de seus respectivos torcedores, sobretudo, à frequência aos estádios. Os novos estádios se tornaram muito caros. O Allianz Parque, especialmente, com tíquete médio elevadíssimo, o maior do Brasil. Assim como a governança dos clubes não pode se prender tãosomente ao resultado financeiro, e como observamos, necessita se preocupar com a conquista de títulos e bom desempenho nas competições, é imprescindível que a gestão não menospreze os torcedores que possuem poder aquisitivo menor, em regra, o maior contingente, mesmo em times considerados representantes da elite da sociedade.

O Allianz Parque possui espaço suficiente nos cerca de 43.000 lugares para abrigar locais com ingressos populares. O que se vê, em resumo, é que os clubes não podem ignorar a estrutura de mercado da qual participam, contudo não devem desprezar suas necessidades, origens e cultura. Haverá sempre tensão permanente entre aumentar receitas e ganhar títulos e entre elevar preços de ingressos para obter maior lucro nos jogos e abrigar o torcedor com menos renda pessoal. Clubes não são empresas comuns, já se viu, que visam somente ao lucro e à satisfação econômica dos acionistas, o torcedor é um tipo de acionista do clube, um relevante "stakeholder", e saber se conduzir entre essas antíteses provavelmente se constitua no maior segredo gerencial dessas instituições.

O aficionado não é só relevante como frequentador do estádio, como sóciotorcedor que assegura receita mensal independemente dos jogos, também não se exaure no papel de consumidor dos produtos comercializados pelo clube de futebol. Ele é uma força representativa que o distingue na sociedade, no ambiente 
futebolístico e diante dos agentes financeiros, constituindo-se em imagem e referência, em impressão e respeito. A dimensão, lealdade, a história e forma de vínculo afetivo o conduz a ser o maior patrimônio tangível e intangível. Exige atenção prioritária.

O romantismo, o denominado futebol-raiz não podem impedir a estruturação do esporte com base no racionalismo organizacional e a inclusão na economia de mercado, muitas vezes esses fatores foram utilizados como argumento para frear a visão de mercado, inarredável em processo econômico, porém, o romantismo não pode nem deve ser descartado, erradicado da relação que envolve o futebol. Ele proporciona a beleza do sentimento indispensável na condição humana. No futebol, romantismo/mercado é um oximoro que demanda ser bem tratado.

Como já vimos, induzido pelas exigências da FIFA para a Copa do Mundo de 2014, a partir de 2007, foi o estádio que propiciou à Sociedade Esportiva Palmeiras, por intermédio do estádio-shopping, o Allianz Parque, a matriz econômica que permite independência financeira, estabilidade e possível perenidade. Mas, toda descoberta, sobretudo aquelas que não são originadas por intencionalidade absoluta, só são percebidas após algum tempo, por vezes, um período nada curto. Recuperando nossas epígrafes, assinalou Galileu Galilei: "Todas as verdades são fáceis de serem entendidas a partir de quando elas são descobertas, o ponto é descobri-las". O descobrimento do Allianz Parque como base da nova matriz econômica do Palmeiras não foi um processo simples nem de fácil apreensão por parte do mundo do esporte no Brasil, sobretudo, da crítica esportiva, cujo o foco se prende demais ao cotidiano do futebol. A possibilidade que ele descortina aos outros clubes, mesmo aqueles não tradicionais com torcidas de menor tamanho e que não alcançam a dimensão nacional, foi menos percebida ainda. Continuando a trilha das epígrafes, John Maynard Keynes advertiu com sabedoria: "A dificuldade real não reside nas novas ideias, mas em conseguir escapar das velhas". O futebol brasileiro permanece em estado de letargia para as novas ideias, muitas já bastante em uso na Europa, para onde se olha como um "locus" inatingível, juntando-se conformismo, com "vira-latismo crônico" e uma boa dose de esperteza utilitária, que favorece aos que detêm o poder nas federações estaduais e na CBF, que sobrevivem no processo de transformismo de 
Gramsci,que aludimos no início do trabalho. Todavia, a força de uma ideia aplicada ao seu tempo correto, é difícil de ser contida absolutamente. Clubes que experimentam gestão com orientação vinda de fora, de lugares onde o futebol se desenvolveu no aspecto não só profissional como econômico, caso do Red Bull Bragantino, que compartilhou o nome e a posição do antigo clube do interior com a matriz austríaca, já se organizam pensando no estádio como fator essencial. O Red Bull Bragantino planeja para breve um estádio moderno, para 20.000 torcedores, adequado ao tamanho da torcida, da cidade e às dimensões do clube, mas inserido no contexto que mencionamos no trabalho.

Albert Einstein fecha nossa visita às epígrafes: "Nós não podemos resolver nossos problemas com o mesmo raciocínio que utilizamos quando os criamos". Entender isso é fundamental para quem deseja mudar de verdade a estrutura do futebol brasileiro. O papel exercido pelo estádio é crucial nessa transformação.

Antes de tudo, devemos reconhecer o impulso suscitado pelo desenvolvimento ocorrido na tecnologia da informação que tornou todo o procedimento mais fácil e exequível. Hoje, os ingressos do setor Gol Norte se esgotam em menos de dez minutos com o torcedor podendo fazê-lo à distância de forma simples, rápida e confortável.

Também cabe respeitar o aspecto fundamental das relações sociais no desenvolvimento do estádio como matriz econômica, questão que normalmente é menosprezada nos dias de hoje, tão intenso no aspecto citado, mas que o tratamento atual resvala quase sempre em direção da procura de algoritmos, fórmulas, números a tratar os fenômenos em vigência na sociedade como ciências exatas ou quase isso. A consciência do direito do consumidor, o reconhecimento por parte do torcedor de sua relevância na vida econômica do clube, fatores insubsistentes no tempo do estádio-arquibancada; a pressão social em busca de melhores condições de higidez, tratamento digno, e quesitos vários que foram tratados evolutivamente pela sociedade e configurados em normas, criaram condições essências para o papel do Allianz Parque na Economia do Futebol.

O estádio é viga mestra na construção da matriz econômica dos clubes, o Allianz Parque é o paradigma, e por isso tomado como tema central desse 
trabalho, porém ele não pode ser o elemento que desloque o clube das relações sociais que o envolvem e dos compromissos que tem com o pilar central de sustentação, o torcedor: alma, si-mesmo, persona e sombra desse esporte. $\mathrm{O}$ espírito da coisa. Sem o combustível humano central, o torcedor, não há futebol. 


\section{BIBLIOGRAFIA}

ACEMOGLU, Daron; ROBINSON, James. Por Que As Nações Fracassam: As Origens do Poder, Prosperidade e da pobreza. Rio de Janeiro: Elsevier, 2012.

AFIF, Antonio. A bola da vez. O marco esportivo como estratégia de sucesso. Editora Infinito, 2000.

ALMEIDA, Julio Gomes de; BELLUZZO, Luiz Gonzaga de Melo. Depois da Queda. Editora Civilização Brasileira, 2002.

ARENDT, Hannah. A condição humana. Editora Forense, 2007.

ARRUDA, José Jobson de Andrade. O Brasil no comércio colonial. São Paulo: Ática, 1980.

ARRUDA, Maria Arminda do Nascimento. Metrópole Cultura. Editora Edusc, 2001.

ARRUDA, José Jobson de Andrade. Historiografia Teoria e Prática. 1ํㅡ. Ed. São

Paulo: Alameda, 2014.

ARAUJO, José Renato de Campos. Imigração e Futebol - O caso Palestra Italia. Editora Sumaré, 2000.

BELLOS, Alex. Futebol o Brasil em Campo. Editora Zahar, 2002.

BOSI, Alfredo. Dialética da Colonização. Editora Companhia das Letras, 2001.

CALDEIRA, José. Ronaldo Glória e Drama do Futebol. Editora Lance, 2002.

CAMPOS, Flávio; ALFONSI, Daniela. Futebol Objetivo das Ciências Humanas. Editora Leya, 2014.

CAMPOS, Vicente Falconi. Gerenciamento pelas diretrizes. Editora Falconi, 2004.

CANO, Wilson. Da década de 1920 à de 1930: Transição Rumo à Crise e à Industrialização no Brasil. Brasília: EconomiA, 2012.

CARVALHAES, J. Um psicólogo no futebol: relatos e pesquisas. São Paulo: Editora Esporte e Educação, 1974.

CIDAR, Antonio Carlos Kfouri; LEONCINI, Marvio Pereira; OLIVEIRA, João José. A nova Gestão do Futebol. Editora FGV, 2002.

COUTINHO, Renata; BELLUZZO, Luiz Gonzaga de Melo. Desenvolvimento Capitalista no Brasil. Editora Brasiliense, 1983. 
DUNNING, Eric. Sport Matters. Editora Lightning Source Inc, 1999.

ELIAS; DUNNING. Deporte y Ocio en el proceso de la Civilizacion. Nova York. Basil Blackwell Publisher Ltd.,Oxford, 1986.

FERNANDES, Florestan. Revolução Burguesa no Brasil. Rio de Janeiro: Ed. Zahar, 1975.

FRANCO Jr., Hilário (2007). A dança dos deuses: futebol, cultura, sociedade. São Paulo, Companhia das Letras. Capítulo 1: Síntese da Europa industrial e colonialista, pp. 25-59.

FOER, Franklin. Como futebol explica o mundo. Editora Zahar, 2005.

FURTADO, Celso. Formação econômica do Brasil. São Paulo: Companhia das Letras, 2007.

GEORGE JR. Claude S., História do Pensamento Administrativo. São Paulo, Cultrix, 1974.

GUTERMAN, Marcos. O futebol explica o Brasil. Editora Contexto. 2009.

GRAMSCI, Antonio. Cadernos do Cárcere. Volume 3. $3^{\text {a }}$ edição. Maquiavel: Notas Sobre o Estado e a Política. Edição Carlos Nelson Coutinho - com Marcos Aurélio Nogueira e Luiz Sérgio Henriques. Rio de Janeiro: Ed. Civilização Brasileira, 2007.

HERNANDEZ, J. A. E. João Carvalhaes, um psicólogo campeão do mundo de futebol. Estudos e Pesquisa em Psicologia, v. 11, 2011.

HOLANDA, Bernardo Borges Buarque de. O Clube como vontade de representação. Editora 7 Letras, 2010.

JUDT, J. Pós-Guerra - Uma história da Europa desde 1945. Lisboa: Edições 70, 2005.

JÚNIOR, Hilário Franco. A Dança dos Deuses - Futebol, Sociedade, Cultura. Editora Schwarcz Ltda.2007.

KAPLAN, R. S. e NORTON, D.P. A Estratégia em Ação: Balanced Scorecard. Rio de Janeiro: Campus, 1997.

KFOURI, Juca. Confesso que perdi. Editora Companhia das Letras, 2017.

LEONCINI, Marvio Pereira. Entendendo o negócio futebol: um estudo sobre a transformação do modelo de gestão estratégica nos clubes de futebol. 2001. 168 f. Tese (Doutorado em Engenharia) - Escola Politécnica, Universidade de São Paulo, São Paulo, 2001. Faperj, 2011. 
MANSSUR, José Francisco; CASTRO, Rodrigo Monteiro de. Futebol, Mercado e Estado. Editora Quartier Latin, 2016.

MASCARENHAS, Gilmar; BIENENSTEIN,Glauco; SÁNCHEZ, Fernanda. O Jogo Continua: Megaeventos Esportivos e Cidades. Editora Faperj, 2011.

MAQUIAVEL, Nicolau. O príncipe (Trad. Antonio Caruccio-Caporale). São Paulo: L\&PM Editores: Porto Alegre, 2011.

MAXIMINIANO, Antonio Cesar Amaru. Introdução a Administração. Editora Atlas, 2011.

MAZZUCCHELLI, Frederico. Os anos de chumbo. Editora Unesp, 2009.

MELLO, J.M. de e NOVAIS, F.A. Capitalismo Tardio e Sociabilidade Moderna. São Paulo: Unesp, 2009.

NOVAIS, Fernando, Aproximações, Estudos de história e Historiografia, Casacnaify, São Paulo: 2005.

NOVAIS, Fernando; MELO, João Manuel Cardoso. Capitalismo tardio e Sociabilidade Moderna. Editora Unesp/ Facamp, 2009.

OLIVEIRA; VASQUEZ. Florestan Fernandes e o capitalismo dependente: elementos para interpretação do Brasil. Rio de Janeiro. Revista Oiko, 2010.

OLIVEIRA, Neuman Gusmão de. O poder dos jogos e os jogos do poder. Editora UFRJ, 2015.

PRIORI, Mary Del; MELO, Vitor de Andrade (Organizadores). História do Esporte no Brasil. Editora Unesp, 2009.

PRONI, Marcelo Weishaupt. A Metamorfose do Futebol. Campinas: Unicamp, 2000.

PRONI, Marcelo Weishaupt. Esporte-Espetáculo e Futebol-Empresa. 1998. 275 f. Tese (Doutorado em Educação Física) - Faculdade de Educação Física, Universidade Estadual de Campinas, Campinas, 1998.

PRONI, Marcelo Weishaupt; FAUSTINO, Rafael Brito; SILVA, Leonardo de Oliveira. Impactos Econômicos de Megaeventos Esportivos. Editora Casa da Educação Física, 2014.

REILLY, Kevan; DEMPSEY, Paul. Big Money Beautiful Game. Editora Nd, 1998.

RODRIGUES, Nelson. À sombra das chuteiras imortais. São Paulo: Cia. das Letras, 1993. p.51- 52: Complexo de vira-latas.

RODRIGUES, Márcio Silva; COSTA, Carlos Everaldo Silva da; GONÇALVES, Júlio Cesar de Santana. A Mercantilização do Futebol Brasileiro. Editora Ex Libris, 2008. 
SERRA, J. Ciclos e Mudanças Estruturais na Economia Brasileira do Após Guerra. Revista Economia Política, 1982.

SMITH, Adam. Riqueza das Nações. Editora Global, 1985.

WEBER M. A ética protestante e o espírito do capitalismo. 3 ed. Trad. de Irene de Q. F. Szmrecsáyi e Tomás J. M. K. Regis Barbosa Szmrecsáyi. São Paulo: Pioneira, 1983.

WILLIAMS, Raymond. Política do Modernismo. Contra os novos conformistas. São Paulo: Unesp, 2001.

WISNIK, José Miguel. Veneno Remédio. Editora Companhia das Letras, 2013.

\section{Revista}

The Economist. Brazil takes off. Londres, 2009.

\section{Sites}

ACERVO ESTADÃO. Como era São Paulo sem Parque Antártica. Disponível em: $\quad<$ http://acervo.estadao.com.br/noticias/acervo,como-era-sao-paulo-semparque-antartica,9339,0.htm> Acesso em: 09 de outubro de 2017.

BDO. 10 Valor das marcas dos clubes brasileiros: finanças dos clubes 2017. Disponível em: <www.bdobrazil.com.br> Acesso em: 17 de maio de 2018.

BDO. Análise de mercado: Clubes Brasileiros 2018. Disponível em: <www.bdobrazil.com.br> Acesso em: 17 de maio de 2018.

BDO. Valor das marcas: 40 clubes brasileiros 2017. Disponível em: <www.bdobrazil.com.br> Acesso em: 17 de maio de 2018.

BOL. Estréia põe à prova " cheque em branco" da CBF para Tite em caos politico. Disponível em: https://www.bol.uol.com.br/copa2018/noticias/2018/06/17/caos-politico-deu-liberdade-inedita-a-tite.htm. Acesso em 17/06/2018.

BLOG AMIR SOMOGGI. Finanças do Palmeiras. Disponível em: <http://blogs.lance.com.br/somoggi/financas-do-palmeiras/> Acessado em: 09 de maio de 2018. 
BLOG RADAMES MANOSSO. Os países membros de COI, FIFA, OMC e ONU. Disponível em: <http://radames.manosso.nom.br/palavras/geografia/os-paisesmembros-de-coi-fifa-e-onu/> Acessado em: 09 de maio de 2018.

CAMPEÕES DO FUTEBOL. História da S.E. Palmeiras. Disponível em: <http://www.campeoesdofutebol.com.br/hist_palmeiras.html> Acesso em: 31 de janeiro de 2018.

DIÁRIO OFICIAL. Balanços Financeiros Sociedade Esportiva Palmeiras. Disponível em: <https://www.imprensaoficial.com.br/\#20/02/2018> Acesso em: 20 de fevereiro de 2018.

EPOCA GLOBO. A impagável dívida pública da Arena Corinthians. Disponível em:<https://epoca.globo.com/esporte/epoca-esporte-

clube/noticia/2017/09/impagavel-divida-publica-da-arena-corinthians.html> Acesso em: 27 de Abril de 2018.

ESPN. Arena Corinthians não foi o único estádio privado da Copa 2014 beneficiado com dinheiro público. Disponível em: $<$ http://www.espn.com.br/blogs/maurocezarpereira/587062_arena-corinthians-naofoi-o-unico-estadio-privado-da-copa-2014-beneficiado-com-dinheiro-publico> Acesso em: 27 de Abril de 2018.

ESPN. Em alta, Corinthians reage, passa Palmeiras e volta a liderar ranking de sócio-torcedores no Brasil. Disponível em: $<$ http://www.espn.com.br/noticia/719560_em-alta-corinthians-reage-passapalmeiras-e-volta-a-liderar-ranking-de-socios-torcedores-no-brasil> Acesso em: 17 de maio de 2018.

ESTADÃO. Allianz Parque um ano. Disponível em: <http://infograficos.estadao.com.br/esportes/allianz-parque-um-ano/allianzparque\%2C-um-ano.html> Acesso em: 17 de maio de 2018.

ESTADÃO. Internacional mantém ponta no ranking de sócio-torcedores no Brasil.

Disponível em: <http://esportes.estadao.com.br/noticias/futebol, internacional-mantem-ponta-noranking-de-socio-torcedores-no-brasil,1131429> Acesso em: 17 de maio de 2018.

EXAME. O Top 10 de sócio-torcedores do Brasil. Disponível em: $<$ https://exame.abril.com.br/blog/esporte-executivo/o-top-10-de-socios-torcedoresdo-brasil/> Acesso em: 17 de maio de 2018.

EXTRA GLOBO. Maracanã é o terceiro estádio do mundo que mais consumiu dinheiro público: $\mathbf{R} \$ \mathbf{1 , 4 5}$ bilhão. Disponível em: <https://extra.globo.com/esporte/maracana-o-terceiro-estadio-do-mundo-que-maisconsumiu-dinheiro-publico-145-bilhao-8348249.html> Acesso em: 27 de Abril de 2018.

FOLHA DE SÃO PAULO. Arena Corinthians, ao final, custará ao menos R\$1,64 bilhão ao clube. Disponível em: < 
http://www1.folha.uol.com.br/esporte/2016/07/1789990-ao-final-do-prazocorinthians-vai-pagar-r-164-bi-pelo-seu-estadio.shtml> Acesso em: 17 de maio de 2018.

FOLHA DE SÃO PAULO. 0 Milagre de Berna. Disponível em: <http://ivraria.folha.com.br/filmes/drama/milagre-berna-dvd-1154924.html> Acessado em: 09 de maio de 2018.

FUTEBOL MELHOR. Torcedômetro. Disponível em: <http://www.futebolmelhor.com.br/> Acesso em: 17 de maio de 2018.

GLOBO ESPORTE. Corinthians, agora líder, e Palmeiras superam Inter em sócio-torcedores.

Disponível

em:

$<$ http://globoesporte.globo.com/sp/futebol/noticia/2015/12/corinthians-agora-lider-epalmeiras-superam-o-inter-em-socios-torcedores.html> Acesso em: 17 de maio de 2018.

GLOBO ESPORTE. Palmeiras quebra próprio recorde e tem as suas maiores rendas do Brasil em 2018. Disponível em: $<$ https://globoesporte.globo.com/numerologos/noticia/palmeiras-quebra-propriorecorde-e-tem-as-duas-maiores-rendas-do-brasil-em-2018.ghtml> Acesso em: Acesso em: 17 de maio de 2018.

LANCE!. 100 anos no Parque dos Sonhos: A ousada ideia de comprar um parque. Disponível em: <http://www.lance.com.br/palmeiras/especialpalestra.html> Acesso em: 06 de fevereiro de 2017.

LANCE!. Palmeiras sobra na turma e oito dos 20 clubes da Série A têm prejuízo com bilheteria. Disponível em: <http://blogs.lance.com.br/superraiox/palmeiras-sobra-turma-oito-20-clubes-serieatem-prejuizo-billheteria/\#disqus_thread> Acesso em: 17 de maio de 2018.

PORTAL BRASIL. 0 Real - Histórico. Disponível em: $<$ http://www.portalbrasil.net/economia_real_historico.htm> Acesso em: 05 de março de 2018.

REVISTA ABRIL. É verdade que a FIFA tem mais filiados que a ONU?. Disponível em: <https://mundoestranho.abril.com.br/esporte/e-verdade-que-a-fifatem-mais-filiados-que-a-onu/> Acessado em: 09 de maio de 2018.

SOCIEDADE ESPORTIVA PALMEIRAS. Estádio Palestra Italia. Disponível em: <http://www.palmeiras.com.br/historia/estadio> Acesso em: 31 de janeiro de 2018.

TORCEDORES.COM. Allianz Parque: $\mathbf{3}$ anos de conquistas e um marco na história alviverde. Disponível em: <https://www.torcedores.com/noticias/2017/11/allianz-faz-3-anos-confira-especial> Acesso em: 07 de fevereiro. 2017.

VIAJE NA HISTÓRIA. Visita ao Allianz Parque. Disponível em: <https://www.viajenahistoria.com.br/visita-ao-allianz-parque/> Acesso em: 07 de fevereiro de 2017. 